\title{
Idaho National Engineering Laboratory Site Environmental Report for Calendar Year 1995
}

\author{
Environmental Science and Research Foundation
}

August 1996
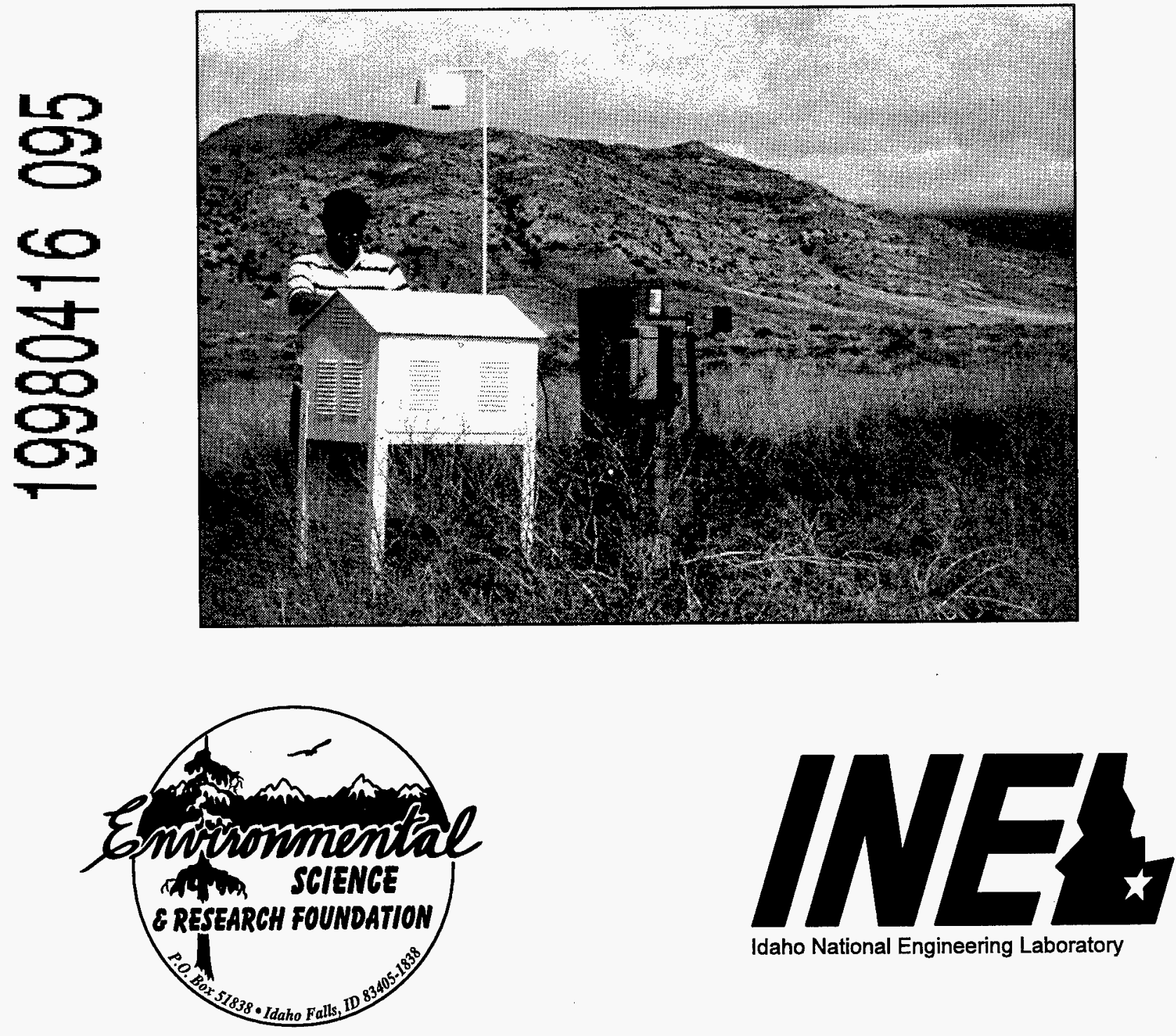

Idaho National Engineering Laboratory 


\section{DISCLAIMER}

This report was prepared as an account of work sponsored by an agency of the United States Government. Neither the United States Government nor any agency thereof, nor any of their employees, makes any warranty, express or implied, or assumes any legal liability or responsibility for the accuracy, completeness, or usefulness of any information, apparatus, product, or process disclosed, or represents that its use would not infringe privately owned rights. Reference herein to any specific commercial product, process, or service by trade name, trademark, manufacturer, or otherwise does not necessarily constitute or imply its endorsement, recommendation, or favoring by the United States Government or any agency thereof. The views and opinions of authors expressed herein do not necessarily state or reflect those of the United States Government or any agency thereof. 


\title{
Idaho National Engineering Laboratory Site Environmental Report for Calendar Year 1995
}

\author{
Russell G. Mitchell \\ Don Peterson \\ Diana L. Hoff \\ Environmental Science and Research Foundation \\ Doyle Markham, Executive Director
}

August 1996

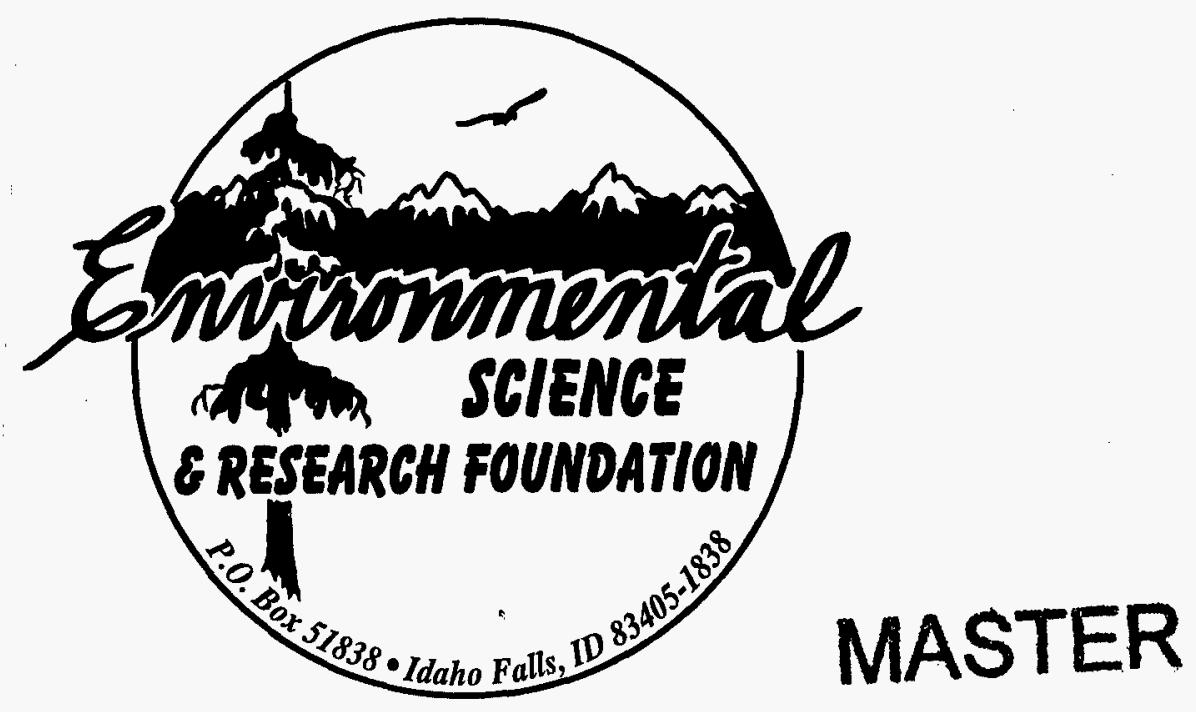

Report was prepared for the U.S. Department of Energy, Idaho operations Office Under Contract DE-AC07-94ID13268 by the Environmental Science and Research Foundation

101 S. Park Avenue, Suite 2; PO Box 51838 Idaho Falls, Idaho 83405-1838 


\section{PREFACE}

Every person in the world is exposed to sources of ionizing radiation-radiant energy that produces ions as it passes through cells. There are three general types of radiation sources: those of natural origin unaffected by human activities, those of natural origin but enhanced by human activities, and those produced by human activities (manmade).

The first group includes terrestrial radiation from natural radiation sources in the ground, cosmic radiation from outer space, and radiation from radionuclides naturally present in the body. Exposures to natural sources may vary depending on the geographical location, and even the altitude, at which a person resides. When such exposures are substantially higher than the average, they are considered to be elevated.

The second group includes a variety of natural sources from which the radiation has been increased by human actions. For example, radon exposures in a given home may be elevated because of natural radionuclides in the soil and rock on which the house is built; however, the radon exposures of occupants may be enhanced by characteristics of the home, such as extensive insulation. Another example is the increased exposure to cosmic radiation that airplane passengers receive when traveling at high altitudes.

The third group includes a variety of exposures from manmade materials and devices such as medical $\mathrm{x}$-rays, radiopharmaceuticals used to diagnose and treat disease, and consumer products containing minute quantities of radioactive materials. Exposures may also result from radioactive fallout from nuclear weapons testing, accidents at nuclear power plants, and other such episodic events caused by man's activities in the nuclear industry. Except for major nuclear accidents, such as the one that occurred at Chernobyl, exposures to workers and members of the public from activities at nuclear industries are very small compared to exposures from natural sources ${ }^{\mathrm{a}}$.

To verify that exposures resulting from operations at the Department of Energy (DOE) nuclear facilities remain very small, each site at which nuclear activities are conducted operates an environmental surveillance program to monitor the air, water and any other pathway whereby radionuclides from operations might conceivably reach workers or members of the public ${ }^{b}$. Environmental surveillance and monitoring results are reported annually to the DOE, Headquarters.

This report presents a compilation of data collected in 1995 for the routine environmental surveillance programs conducted on and around the Idaho National Engineering Laboratory (INEL). During 1995, the offsite surveillance program was conducted by the Environmental Science and Research Foundation. Onsite surveillance was performed by Lockheed Idaho Technologies Company (LITCO). Ground-water monitoring, both on and offsite, was performed by the U. S. Geological Survey (USGS). This report also presents summaries of facility effluent monitoring data collected by INEL contractors.

This report, prepared in accordance with the requirements in DOE Order 5400.1, is not intended to cover the numerous special environmental research programs being conducted at the INEL by the Foundation, LITCO, USGS, and others.

\footnotetext{
- Paraphrased from National Council on Radiation Protection and Measurements, lonizing Radiation Exposure of the Population of the United States, NCRP Report No. 93, September 1, 1987, p. 1.

- DOE Order 5400.1, "General Environmental Protection Program", November 9, 1988.
} 
Section 9.g of DOE 5400.1 exempts the Naval Nuclear Propulsion Program's Naval Reactors Facility (NRF) from the provisions of this order and preparation of the Annual Site Environmental Report. The Naval Nuclear Propulsion Program separately maintains an environmental protection program to assure compliance with all applicable environmental laws and regulations. Monitoring data and information specific to NRF, similar to that of this report, are provided in a separate annual environmental report issued by NRF. For completeness, however, some information from onsite monitoring programs at NRF is included in this report.

The Idaho National Engineering Laboratory Site Environmental Report for Calendar Year 1995 was prepared by the Environmental Science and Research Foundation under DOE Contract DE-AC97-94ID13268. 


\section{HELPFUL INFORMATION FOR THE GENERAL READER}

\section{Scientific Notation}

Scientific notation is used to express numbers which are very small and very large. A very small number will be expressed with a negative exponent, for example, $1.3 \times 10^{-6}$. To convert this number to the more commonly used form, the decimal point must be moved left by a number of places equal to the exponent (in this case 6). The number thus becomes 0.0000013 .

For large numbers, those with a positive exponent, the decimal point is moved to the right by the number of places equal to the exponent. The number $1,000,000$ (or one million) can be written as 1.0 $\mathrm{x} 10^{6}$.

\section{Unit Prefixes}

Units for very small and very large numbers are commonly expressed with a prefix. One example is the prefix kilo (abbreviated $\mathrm{k}$ ), which means 1,000 of a given unit. A kilometer is therefore equal to 1,000 meters. Other prefixes used in this report are:

$\begin{array}{cc}\text { Prefix } & \text { Abbreviation } \\ \text { Mega } & \mathrm{M} \\ \text { centi } & \mathrm{c} \\ \text { milli } & \mathrm{m} \\ \text { micro } & \mu \\ \text { nano } & \mathrm{n} \\ \text { pico } & \mathrm{p}\end{array}$

$$
\begin{gathered}
\text { Meaning } \\
1,000,000\left(=1 \times 10^{6}\right) \\
1 / 100\left(=1 \times 10^{-2}\right) \\
1 / 1,000\left(=1 \times 10^{-3}\right) \\
1 / 1,000,000\left(=1 \times 10^{-6}\right) \\
1 / 1,000,000,000\left(=1 \times 10^{-9}\right) \\
1 / 1,000,000,000,000\left(=1 \times 10^{-12}\right)
\end{gathered}
$$

\section{Units of Radioactivity and Radiation Exposure and Dose}

The basic unit of radioactivity used in this report is the curie (abbreviated $\mathrm{Ci}$ ). The curie was historically based on the radionuclide Radium-226, of which one gram decays at the rate of 37 billion disintegrations per second. For any other radionuclide, one curie is the amount of the radionuclide that decays at this same rate.

Radiation exposure is expressed in terms of the Roentgen $(\mathrm{R})$, the amount of ionization produced by gamma radiation in air. Dose is given in units of "Roentgen equivalent man" or rem, which takes into account the effect of radiation on tissues. For the types of environmental radiation generally encountered, the unit of Roentgen is approximately numerically equal to the unit of rem. A 
person-rem is the sum of the doses received by all individuals in a population. Doses may also be expressed in the Système International unit Sv, where $1 \mathrm{~Sv}$ equals $100 \mathrm{rem}$.

\section{Units of Environmental Concentrations}

Concentration of radioactivity in air samples and liquid samples such as water and milk is expressed in units of microcuries per milliliter $(\mu \mathrm{Ci} / \mathrm{mL})$ of air or liquid. Radioactivity in foodstuffs is expressed in microcuries per gram $(\mu \mathrm{Ci} / \mathrm{g})$, dry weight. Radioactivity in soil samples is expressed in terms of both the sample dry weight and the ground surface area represented by the sample: picocuries per gram ( $\mathrm{pCi} / \mathrm{g})$ and nanocuries per square meter $\left(\mathrm{nCi} / \mathrm{m}^{2}\right)$. Annual human radiation exposure, measured by environmental dosimeters, is expressed in units of milliRoentgens (mR). This is sometimes expressed in terms of dose as millirem (mrem), after being multiplied by an appropriate dose equivalent conversion factor.

\section{Uncertainty of Measurements}

Due to a variety of factors, there is always an uncertainty associated with the measurement of environmental contaminants. For radioactivity, the predominant source of uncertainty is due to the inherent statistical nature of radioactive decay events, particularly at the low activity levels encountered in environmental samples. The uncertainty of a measurement is denoted by following the result with a " \pm " (uncertainty) term. This report follows convention in reporting the uncertainty as a $95 \%$ confidence limit (or interval). That means there is about $95 \%$ confidence that the real concentration in the sample lies somewhere between the measured (reported) concentration minus the uncertainty term and the measured (reported) concentration plus the uncertainty term.

\section{Negative Numbers as Results}

Environmental measurements are frequently conducted at levels where the contaminant (such as radioactivity) cannot be distinguished from natural background levels. In this case, the result will still be reported, even though it is below the measurement system's detection limit or is less than zero. Negative values occur when the measured result is less than a preestablished average background level for the particular system and procedure used. These values, rather than "not detectable" or "zero," are reported to better enable statistical analyses and observe trends or bias in the data. 


\section{Radionuclide Nomenclature}

Radionuclides are frequently expressed with the one- or two-letter chemical symbol for the element. Radionuclides may have many different isotopes, which are shown by a superscript to the left of the symbol. This number is the atomic weight of the isotope (the number of protons and neutrons in the nucleus of the atom). Radionuclide symbols used in this report are shown in the following table.

\begin{tabular}{|c|c|c|c|}
\hline Radionuclide & Symbol & $\underline{\text { Radionuclide }}$ & Symbol \\
\hline Tritium & ${ }^{3} \mathrm{H}$ & Xenon-133 & ${ }^{133} \mathrm{Xe}$ \\
\hline Beryllium-7 & ${ }^{7} \mathrm{Be}$ & Iodine-134 & ${ }^{134} \mathrm{I}$ \\
\hline Carbon-14 & ${ }^{14} \mathrm{C}$ & Cesium-134 & ${ }^{134} \mathrm{Cs}$ \\
\hline Sodium-22 & ${ }^{22} \mathrm{Na}$ & Iodine-135 & ${ }^{135}$ I \\
\hline Sodium-24 & ${ }^{24} \mathrm{Na}$ & Xenon-135 & ${ }^{135} \mathrm{Xe}$ \\
\hline Potassium-40 & ${ }^{40} \mathrm{~K}$ & Cesium-137 & ${ }^{137} \mathrm{Cs}$ \\
\hline Argon-41 & ${ }^{41} \mathrm{Ar}$ & Cesium-138 & ${ }^{138} \mathrm{Cs}$ \\
\hline Scandium-46 & ${ }^{46} \mathrm{Sc}$ & Xenon-138 & ${ }^{138} \mathrm{Xe}$ \\
\hline Chromium-51 & ${ }^{51} \mathrm{Cr}$ & Barium-139 & ${ }^{139} \mathrm{Ba}$ \\
\hline Manganese-54 & ${ }^{54} \mathrm{Mn}$ & Cesium-140 & ${ }^{140} \mathrm{Cs}$ \\
\hline Iron-55 & ${ }^{55} \mathrm{Fe}$ & Cerium-141 & ${ }^{141} \mathrm{Ce}$ \\
\hline Cobalt-57 & ${ }^{57} \mathrm{Co}$ & Cerium-144 & ${ }^{144} \mathrm{Ce}$ \\
\hline Cobalt-58 & ${ }^{58} \mathrm{Co}$ & Europium-152 & ${ }^{152} \mathrm{Eu}$ \\
\hline Cobalt-60 & ${ }^{60} \mathrm{Co}$ & Europium-154 & ${ }^{154} \mathrm{Eu}$ \\
\hline Zinc-65 & ${ }^{65} \mathrm{Zn}$ & Hafnium-181 & ${ }^{181} \mathrm{Hf}$ \\
\hline Krypton-85 & ${ }^{85} \mathrm{Kr}$ & Mercury-203 & ${ }^{203} \mathrm{Hg}$ \\
\hline Krypton-87 & ${ }^{87} \mathrm{Kr}$ & Thallium-208 & ${ }^{208} \mathrm{Tl}$ \\
\hline Krypton-88 & ${ }^{88} \mathrm{Kr}$ & Lead-212 & ${ }^{212} \mathrm{~Pb}$ \\
\hline Rubidium-88 & ${ }^{88} \mathrm{Rb}$ & Bismuth-212 & ${ }^{212} \mathrm{Bi}$ \\
\hline Rubidium-89 & ${ }^{89} \mathrm{Rb}$ & Lead-214 & ${ }^{214} \mathrm{~Pb}$ \\
\hline Strontium-90 & ${ }^{90} \mathrm{Sr}$ & Bismuth-214 & ${ }^{214} \mathrm{Bi}$ \\
\hline Yttrium-90 & ${ }^{90} \mathrm{Y}$ & Radon-220 & ${ }^{220} \mathrm{Rn}$ \\
\hline Yttrium-91 & ${ }^{91} \mathrm{Y}$ & Radon-222 & ${ }^{222} \mathrm{Rn}$ \\
\hline Niobium-94 & ${ }^{94} \mathrm{Nb}$ & Radium-226 & ${ }^{226} \mathrm{Ra}$ \\
\hline Niobium-95 & ${ }^{95} \mathrm{Nb}$ & Actinium-228 & ${ }^{228} \mathrm{Ac}$ \\
\hline Technetium-99 & ${ }^{99} \mathrm{Tc}$ & Thorium-232 & ${ }^{232} \mathrm{Th}$ \\
\hline Ruthenium-103 & ${ }^{103} \mathrm{Ru}$ & Uranium-234 & ${ }^{234} \mathrm{U}$ \\
\hline Ruthenium-106 & ${ }^{106} \mathrm{Ru}$ & Uranium-235 & ${ }^{235} \mathrm{U}$ \\
\hline Silver-110 & ${ }^{110} \mathrm{Ag}$ & Uranium-238 & ${ }^{238} \mathrm{U}$ \\
\hline Antimony-125 & ${ }^{125} \mathrm{Sb}$ & Plutonium-238 & ${ }^{238} \mathrm{Pu}$ \\
\hline Iodine-129 & ${ }^{129} \mathbf{I}$ & Plutonium-239/240 & ${ }^{239 / 240} \mathrm{Pu}$ \\
\hline Iodine-131 & ${ }^{131} \mathrm{I}$ & Americium-241 & ${ }^{241} \mathrm{Am}$ \\
\hline Iodine- 132 & ${ }^{132} \mathrm{I}$ & & \\
\hline Iodine-133 & ${ }^{133} \mathrm{I}$ & & \\
\hline
\end{tabular}




\section{ACRONYMS}

ANL-W Argonne National

Laboratory-West

ARA

BTU

CAA

CERCLA

CFA

CFR

CFSGF

CWA

DEQ

DOE

DOE-CH

DOE-ID

DOE-HQ

DWR

EBR-II

Clean Air Act

Comprehensive

Act Facility

Clean Water Act

Operations Office

Headquarters

Resources
Auxiliary Reactor Area

British Thermal Unit

Environmental Response,

Compensation, and Liability

Central Facilities Area

Code of Federal Regulations

Coal-Fired Steam Generating

(Idaho) Division of

Environmental Quality

U.S. Department of Energy

Department of Energy,

Chicago Operations Office

Department of Energy, Idaho

Department of Energy,

(Idaho) Department of Water

INEL

INWMIS

GSA

ICPP

IMPROVE

INET

INWMIS

ISU

LESAT

LITCO

LOFT
Experimental Field Station

Environmental Impact

Statement

Environmental

Measurements Laboratory

Environmental Protection

Agency

Emergency Planning and Community Right-to-Know Act

General Services

Administration

Idaho Chemical Processing

Plant

Interagency Monitoring of

Protected Visual

Environments

Idaho National Engineering

Laboratory

INEL Nonradiological Waste Management Information System

Idaho State University

Lockheed Environmental Systems and Technology

Lockheed Idaho

Technologies Company

Loss of Fluid Test 


\section{ACRONYMS (Cont.)}

MCL

$\mathrm{Na} / \mathrm{K}$

NCRP

NEPA

NESHAPs

NIOSH

NIST

NOAA/ARL

NOV

NPDES

NRF

NWCF

PBF

QAP
Maximum Contaminant

Level

Sodium/Potassium Waste

National Council on

Radiation Protection and

Measurements

National Environmental

Policy Act

National Emission Standards

for Hazardous Air Pollutants

National Institute of

Occupational Safety and

Health

National Institute of

Standards and Technology

National Oceanic

and Atmospheric

Administration/Air

Resources Laboratory

Notice of Violation

National Pollution Discharge

Elimination System

Naval Reactors Facility

New Waste Calcining

Facility

Power Burst Facility

Quality Assessment Program
RCRA

RESL

RI/FS

RML

RWMC

RWMIS

SARA

SMC

SWPPP

TAN

TLD

TRA

TSF

USGS
Resource Conservation and Recovery Act

Radiological and Environmental

Sciences Laboratory

Remedial Investigation/ Feasibility Study

Radiological

Measurements

Laboratory

Radioactive Waste

Management Complex

Radioactive Waste

Management

Information System

Superfund Amendment and Reauthorization Act

Specific Manufacturing Capability Facility

Storm Water Pollution

Prevention Plan

Test Area North

Thermoluminescent

Dosimeter

Test Reactor Area

Technical Services

Facility

U.S. Geological Survey 


\section{ACRONYMS (Cont.)}

WERF

WLAP

WRRTF
Waste Experimental

Reduction Facility

Wastewater Land Application

Permit

Water Reactor Research Test

Facility 


\section{EXECUTIVE SUMMARY}

The results of the various monitoring programs for 1995 indicated that radioactivity from the Idaho National Engineering Laboratory (INEL) operations could generally not be distinguished from worldwide fallout and natural radioactivity in the region surrounding the INEL. Although some radioactive materials were discharged during INEL operations, concentrations and doses to the surrounding population were far less than State of Idaho and Federal health protection guidelines.

Chapter 2 of the report summarizes INEL activities related to compliance with environmental regulations and laws, describes various environmental issues and activities, and summarizes INEL permits for 1995. Chapter 3 provides a description of major activities and milestones in the waste management, environmental restoration, and other environmental programs.

The major portion of this report summarizes results of the environmental surveillance programs conducted by the Environmental Science and Research Foundation and Lockheed Idaho Technologies Company (LITCO). This includes the collection of foodstuffs at the INEL boundary and distant offsite locations, and the collection of air and water samples at onsite locations and offsite boundary and distant locations. The report also compares and evaluates the sample results to appropriate federal regulations and standards and discusses implications, if any. The U.S. Geological Survey (USGS) ground-water monitoring program is briefly summarized and data from USGS reports are included in maps showing the spread of contaminants in ground water. Effluent monitoring and nonradiological drinking water monitoring performed by INEL contractors are discussed briefly and data are summarized in tables.

Gross alpha and gross beta measurements, which are used as a screening technique for air filters, were investigated by making statistical comparisons between onsite or boundary location concentrations and the distant community group concentrations. No statistical differences were found in gross alpha concentrations. For gross beta, statistical differences were noted in about $5 \%$ of the offsite comparisons and $9 \%$ of the onsite comparisons. At least some of these statistical differences may have been related to operations at the INEL, but no source was identified.

Air samples were also analyzed for specific radionuclides. Some manmade radionuclides were detected at offsite locations, but most were near the minimum detectable concentration and their presence was attributable to natural sources, worldwide fallout, or statistical variations in the analytical results rather than to INEL operations.

Plutonium-239/240 and Americium-241 found at two onsite locations, and possibly Strontium-90 detected at one onsite location, were attributed to resuspension of soil particles by construction activities near INEL facilities. No source was determined for the presence of Plutonium-238 and Plutonium-239/240 at two onsite locations. The annual concentrations of all specific nuclides detected at all locations were well below the DOE's derived concentration guides for radiation protection ${ }^{\mathrm{a}}$.

Tritium was detected in some atmospheric moisture and precipitation samples, but concentrations were similar at distant, boundary, and onsite locations indicating its presence was

\footnotetext{
a Derived concentration guides (DCG) are contained in DOE Order
} 5400.5 . 
likely due to natural and fallout sources rather than to INEL activities.

Gross alpha and gross beta activity were measured in drinking and surface water samples. One offsite surface water sample contained a gross beta concentration that was outside the normal range for this parameter, but further analysis indicated that activity was likely due to excess sediment in the sample. Elevated concentrations of gross beta were seen in samples from two wells at an onsite facility during June sampling. Annual averages for all onsite and offsite drinking water samples were below the maximum contaminant level established by the Environmental Protection Agency (EPA) for public drinking water systems.

Five offsite water samples contained detectable tritium concentrations attributable to natural processes or statistical variations. Five onsite production (drinking water) wells contained measurable concentrations of tritium. An effective dose equivalent of $0.7 \mathrm{mrem} / \mathrm{yr}$ was estimated for INEL workers at the Central Facilities Area, the location with the highest tritium concentration in drinking water. Production wells in the vicinity of the Idaho Chemical Processing Plant contained detectable levels of ${ }^{90} \mathrm{Sr}$. Samples from June indicated elevated concentrations of ${ }^{90} \mathrm{Sr}$ relative to other samples taken in recent years, but these concentrations were below the EPA maximum contaminant level.

One milk sample contained ${ }^{131} \mathrm{I}$ just above the minimum detectable concentration. Tritium was found in five samples of milk, with similar concentrations reported for distant and boundary locations. Six samples contained detectable concentrations of ${ }^{90} \mathrm{Sr}$. These concentrations were consistent with levels seen in samples nationwide, as reported by the EPA. Some food samples (lettuce, wheat, potatoes) contained small amounts of ${ }^{137} \mathrm{Cs}$ and ${ }^{90} \mathrm{Sr}$, two components of soil resulting from worldwide fallout. Low concentrations of ${ }^{137} \mathrm{Cs}$ were found in muscle tissue and liver of some game animals and sheep. The levels were consistent with the concentrations from game animals both onsite and offsite in recent years.

Ionizing radiation measured simultaneously at the INEL boundary and distant locations using environmental dosimeters showed only natural background levels.

For details on monitoring results, see the appropriate sections that summarize results of radioactive, nonradioactive, and ground-water monitoring and surveillance programs.

A measurable amount of radioactivity, primarily in the form of noble gases, is released into the atmosphere annually from various plant facilities and is subsequently carried offsite. Upon reaching the INEL boundary, this radioactivity is in such a low concentration that its effect on direct radiation levels cannot normally be measured, but its potential contribution to radiation doses to offsite residents was nevertheless calculated using computer models.

The hypothetical maximum individual effective dose equivalent was found to occur near Mud Lake and was calculated to be 0.008 mrem $\left(8 \times 10^{-5} \mathrm{mSv}\right)$ using the MESODIF air dispersion model. The calculation considered continuous submersion in and inhalation of radioactivity in air, ingestion of radioactivity in leafy vegetables and milk, and exposure to radioactive particulates deposited on the ground surface at that location. This calculated effective dose equivalent is about $0.002 \%$ of the natural background radiation effective dose equivalent of approximately $360 \mathrm{mrem}$ per year in this area.

The 1995 effective dose equivalent to the maximally exposed individual, calculated using the CAP-88 computer code that is required to demonstrate compliance with EPA regulations, was $0.018 \mathrm{mrem}(0.005 \%$ of background). The model predicted the maximally exposed 
individual resided at Frenchman's Cabin, located at the INEL's southern boundary. This location is currently inhabited only during portions of the year. See the section entitled "Maximum Individual Dose-Airborne Emissions Pathway" for a complete discussion of the two different computer models used. The maximum calculated dose to an individual by either of the methods was clearly in compliance with the applicable radiation protection standards.

The maximum potential population dose from submersion, ingestion, inhalation, and deposition to the approximately 121,500 people residing within an $80-\mathrm{km}$ (50-mi) radius from the geographical center between the Test Reactor Area and the Idaho Chemical Processing Plant facilities of the INEL was estimated to be 0.08 person-rem $\left(8 \times 10^{-4}\right.$ person-Sv) using the MESODIF air dispersion model. This population dose is less than $0.0002 \%$ of the estimated 42,500 person-rem (425 person-Sv) population dose from natural background radioactivity. These calculations and their implications are discussed in the section "Evaluation of Potential Dose to the Public."

Ground-water monitoring was performed at the INEL by the USGS using over 125 wells that tap the Snake River Plain Aquifer. Results of a number of special studies detailing water quality in the aquifer were published. Five purgeable organic compounds were found in wells at the INEL, including one well used for drinking water. Concentrations of organic compounds were below EPA maximum contaminant levels for these compounds.

Routine monitoring of ground water was also conducted by contractors operating facilities at the INEL. Water samples taken from the wellhead showed purgeable organic compounds were above the maximum contaminant level for trichlorethylene at one Test Area North well, and carbon tetrachloride during one month at the Radioactive Waste Management Complex. At Test Area North, an aerating system known as a sparger is used to volatize the trichloroethylene and remove it prior to the water entering the distribution system. This has resulted in organic compounds remaining below applicable maximum contaminant levels in the distribution system.

Concentrations of copper and lead were below regulatory guidelines in drinking water. Other inorganic constituents were also below regulatory limits.

Total suspended particulate concentrations in air were higher at distant and boundary locations than at onsite locations. A total of 122 metric tons of nitrogen dioxide and 110 metric tons of sulfur dioxide were released from INEL facilities. Nitrogen dioxide and sulfur dioxide concentrations, both calculated for the INEL boundary using meteorological models and measured at onsite locations, were well below air quality regulatory limits. Monitoring of liquid effluent streams indicated that all were below applicable guidelines.

The State of Idaho Oversight Program conducted an independent program of collecting and analyzing air, water, and milk samples at selected locations, including some of the Foundation and LITCO environmental surveillance program locations. Comparisons of Foundation, LITCO, and State data indicate results were similar among the three programs, considering the variations expected when three organizations maintain different sampling and analysis schedules and use different analytical laboratories. 


\section{CONTENTS}

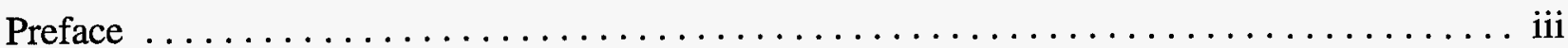

Helpful Information for the General Reader $\ldots \ldots \ldots \ldots \ldots \ldots \ldots \ldots \ldots \ldots, v$

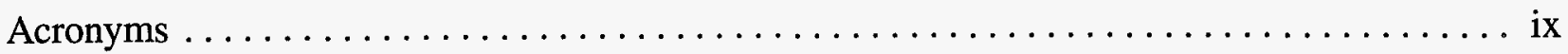

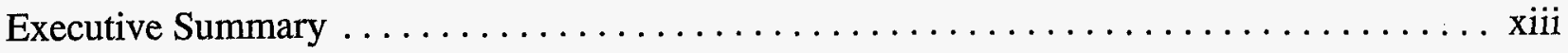

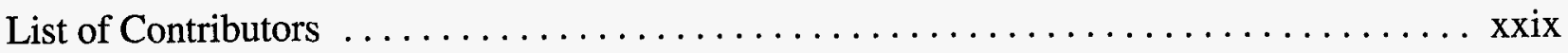

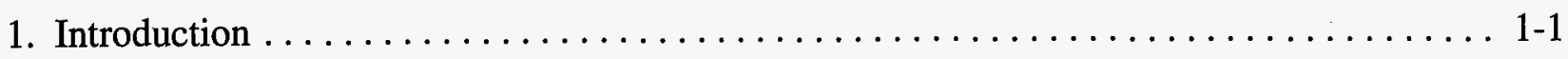

1.1 Site Description $\ldots \ldots \ldots \ldots \ldots \ldots \ldots \ldots \ldots \ldots \ldots \ldots \ldots \ldots \ldots \ldots \ldots \ldots \ldots \ldots \ldots, 3$

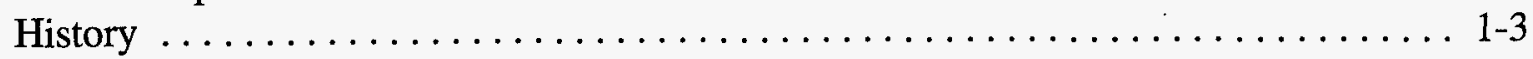

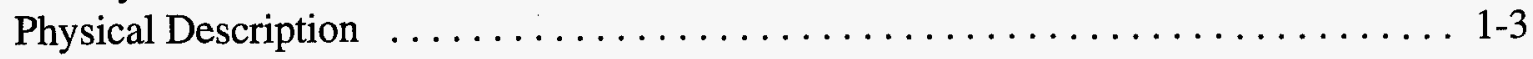

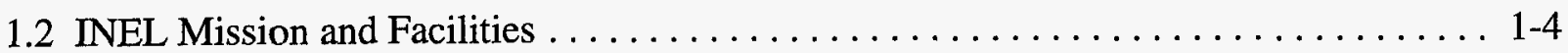

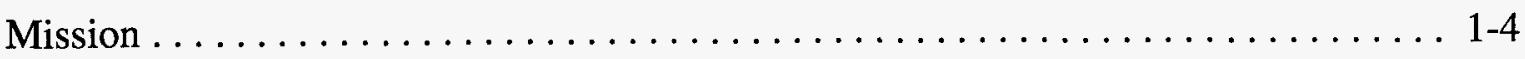

Facilities $\ldots \ldots \ldots \ldots \ldots \ldots \ldots \ldots \ldots \ldots \ldots \ldots \ldots \ldots \ldots \ldots \ldots \ldots \ldots \ldots, 4$

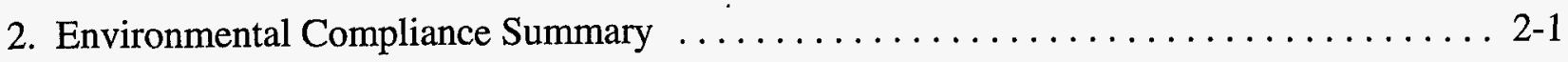

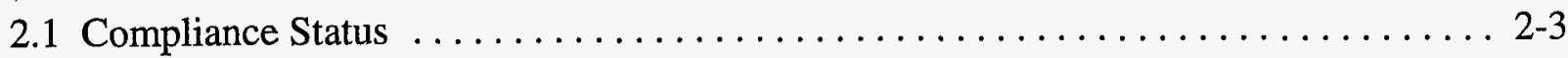

Comprehensive Environmental Response, Compensation and Liability Act $\ldots \ldots \ldots 2-3$

Emergency Planning and Community Right-to-Know Act $\ldots \ldots \ldots \ldots \ldots \ldots \ldots .2-3$

Natural Resource Trusteeship \& Natural Resources Damage Assessment . . . . . . . . 2-4

Clean Air Act . . . . . . . . . . . . . . . . . . . . . . . . . . . . . . .

National Emission Standards for Hazardous Air Pollutants . . . . . . . . . . . . . 2 2-7

Clean Water Act ....................................... 2-7

National Pollutant Discharge Elimination System Point Source

Discharge Permits ................................... 2-8

Executive Order 11990-Protection of Wetlands . . . . . . . . . . . . . . 2 2-9

Executive Order 11988-Floodplain Management ..................... 2-9

State of Idaho Wastewater Land Application Permits . . . . . . . . . . . . . 2-10

Resource Conservation and Recovery Act ....................... 2-10

Federal Facility Compliance Act $\ldots \ldots \ldots \ldots \ldots \ldots \ldots \ldots \ldots \ldots \ldots \ldots \ldots \ldots \ldots \ldots, 2-13$

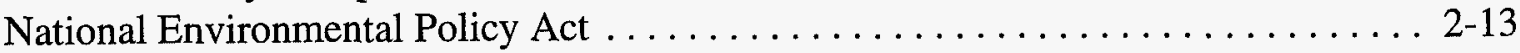

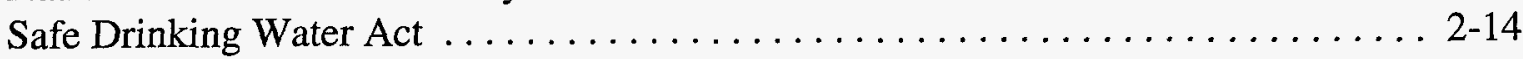

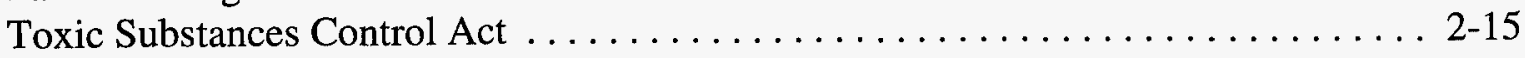

Federal Insecticide, Fungicide, and Rodenticide Act . . . . . . . . . . . . . 2-16

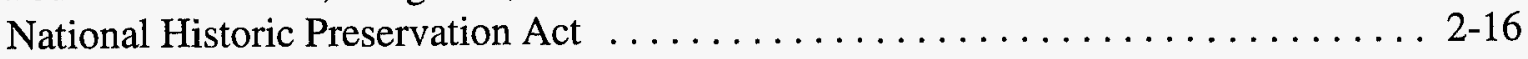




\section{CONTENTS (Cont.)}

Native American Grave Protection and Repatriation Act $\ldots \ldots \ldots \ldots \ldots . \ldots 2-17$

Endangered Species Act . . . . . . . . . . . . . . . . . . . . 2-17

2.2 Other Major Environmental Issues and Activities $\ldots \ldots \ldots \ldots \ldots \ldots \ldots \ldots$

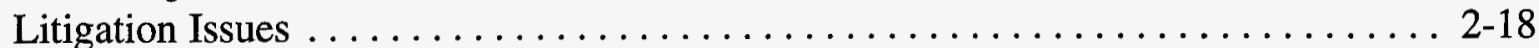

Ground-water Monitoring Program Activities . . . . . . . . . . . . . . 2-21

Health Studies . . . . . . . . . . . . . . . . . . . . . . . 2-22

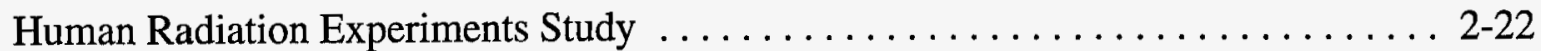

Tiger Team Assessment Corrective Actions . . . . . . . . . . . . . . . 2-23

Environmental Occurrences . . . . . . . . . . . . . . . . . . . . . 2-23

Environmental Oversight and Monitoring Agreement $\ldots \ldots \ldots \ldots \ldots \ldots \ldots \ldots$ 2-25

The Environmental Management Site Specific Advisory Board-Idaho National

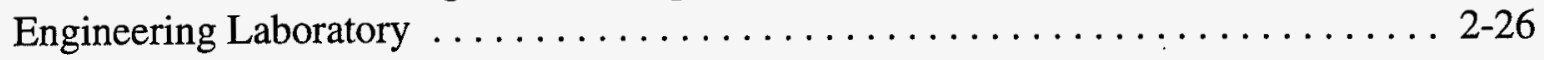

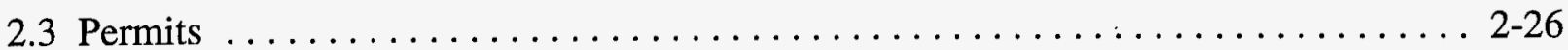

3. Environmental Program Information $\ldots \ldots \ldots \ldots \ldots \ldots \ldots \ldots \ldots \ldots \ldots \ldots \ldots \ldots \ldots \ldots$

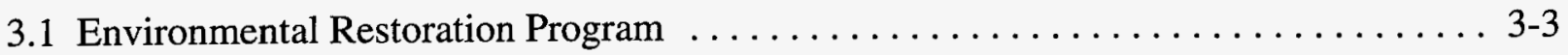

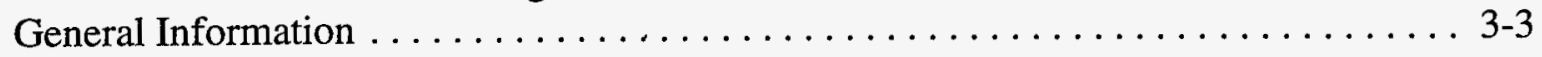

Waste Area Group $1-$ Test Area North . . . . . . . . . . . . . . . . . . . 3-4

Waste Area Group 2 -Test Reactor Area . . . . . . . . . . . . . . . . . . 3-5

Waste Area Group 3-Idaho Chemcial Processing Plant . . . . . . . . . . . . 3-6

Waste Area Group 4-Central Facilites Area . . . . . . . . . . . . . . . . . 3-6

Waste Area Group 5-Power Burst Facility/Auxiliary Reactor Area . . . . . . . . . . . 3-7

Waste Area Group 6-Boiling Water Reactor Experiment . . . . . . . . . . . . 3-8

Waste Area Group 7-Radioactive Waste Managment Complex . . . . . . . . . . . . . 3-9

Waste Area Group $8-$ Naval Reactors Facility . . . . . . . . . . . . . . . . . 3-10

Waste Area Group 9-Argonne National Laboratory-West . . . . . . . . . . . . . 3-11

Waste Area Group 10--Miscellaneous Sites/Snake River Plain Aquifer . . . . . . . . 3-11

Decontamination, Dismantlement, Demolition Activites . . . . . . . . . . 3-12

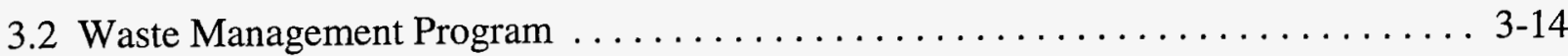

General Information . . . . . . . . . . . . . . . . . . . . . . . $3-14$

Accomplishments of the Waste Management Program $\ldots \ldots \ldots \ldots \ldots \ldots \ldots$. . . . . . . . .

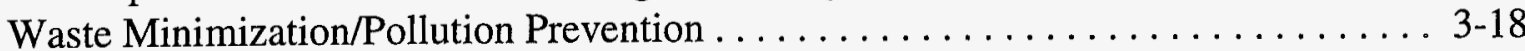

Recycle/Re-use of Excess Materials . . . . . . . . . . . . . . . . . . . 3-19

Waste Treatment Accomplishments $\ldots \ldots \ldots \ldots \ldots \ldots \ldots \ldots \ldots \ldots \ldots \ldots \ldots$. . . . . . . . . . . .

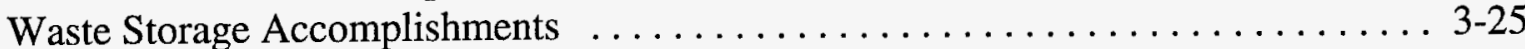

Waste Disposal Accomplishments . . . . . . . . . . . . . . . . . 3-25 


\section{CONTENTS (Cont.)}

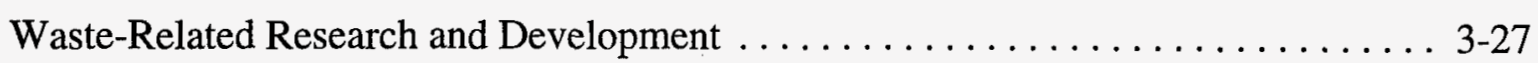

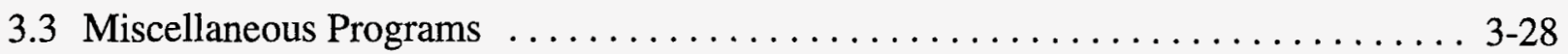

Public Involvement in INEL Program Activities . . . . . . . . . . . . . . . $3-28$

Public Communication and Education Activities $\ldots \ldots \ldots \ldots \ldots \ldots \ldots \ldots \ldots .23-29$

INEL-Sponsored Academic Programs . . . . . . . . . . . . . . . . . . . . 3-31

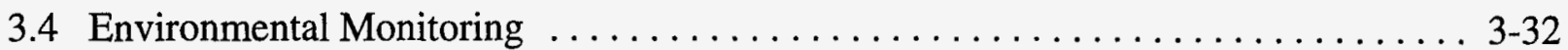

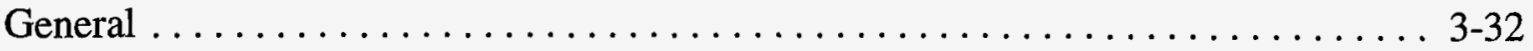

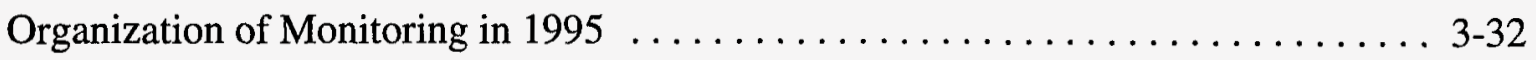

4. Environmental Radiological Program Information $\ldots \ldots \ldots \ldots \ldots \ldots \ldots \ldots \ldots$ 4-1

4.1 Environmental Surveillance Program Description ................... 4-3

High-Volume Air Samplers . . . . . . . . . . . . . . . . . . . . . . . . . . 4-3

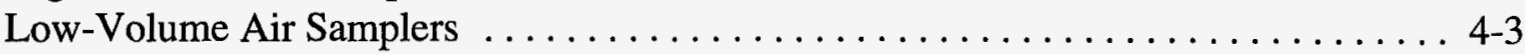

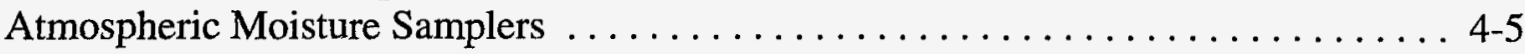

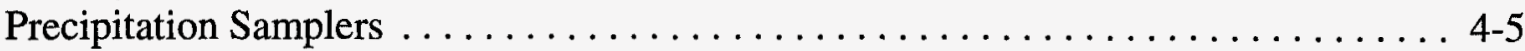

Water Sampling Program $\ldots \ldots \ldots \ldots \ldots \ldots \ldots \ldots \ldots \ldots \ldots \ldots \ldots, 4,5$

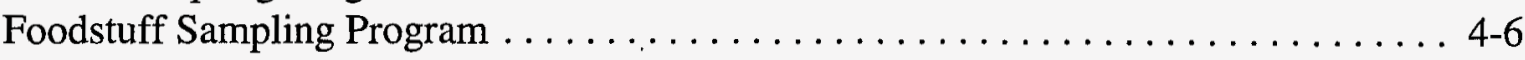

Environmental Dosimeters .............................. 4-8

4.2 Environmental Surveillance Program Results $\ldots \ldots \ldots \ldots \ldots \ldots \ldots \ldots \ldots \ldots$. 4.9

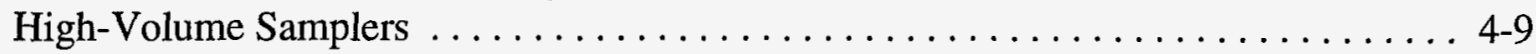

Low-Volume Charcoal Cartridges ............................ 4-9

Low-Volume Gross Alpha . . . . . . . . . . . . . . . . . . . . . . . . .

Low-Volume Gross Beta $\ldots \ldots \ldots \ldots \ldots \ldots \ldots \ldots \ldots \ldots \ldots \ldots \ldots \ldots . \ldots \ldots$

Low-volume Specific Radionuclides . . . . . . . . . . . . . . . . . . . . 4 4-14

Atmospheric Moisture . . . . . . . . . . . . . . . . . . . . . . . . . . . . 4-19

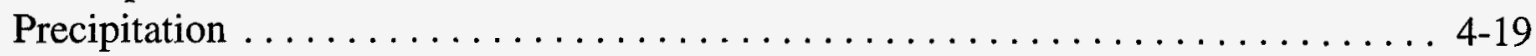

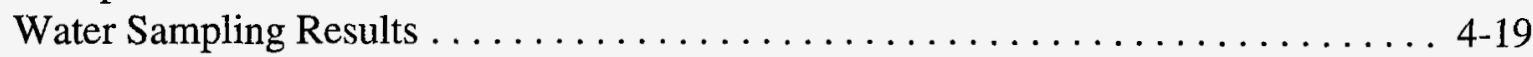

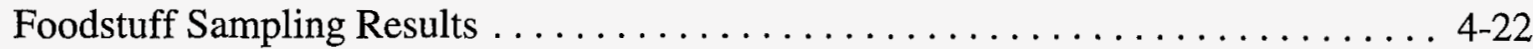

Environmental Dosimeters . . . . . . . . . . . . . . . . . . . . . . . . .

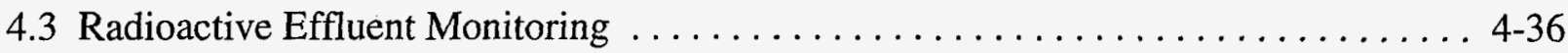

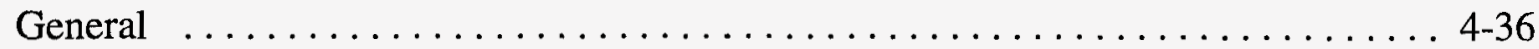

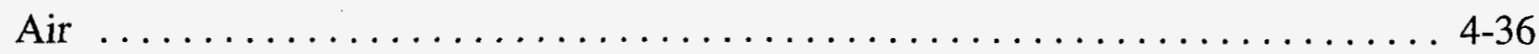

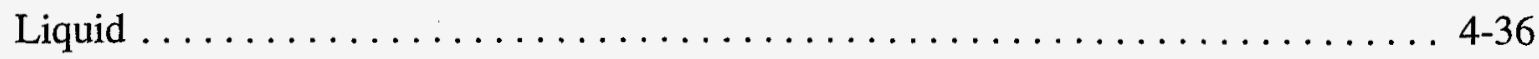

4.4 Evaluation of Potential Radiation Dose to the Public $\ldots \ldots \ldots \ldots \ldots \ldots \ldots$. 4 -36 


\section{CONTENTS (Cont.)}

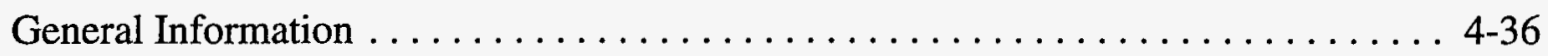

Maximum Individual Dose-Airborne Emissions Pathway . . . . . . . . . . . . 4-39

Maximum Individual Dose-Game Ingestion Pathway $\ldots \ldots \ldots \ldots \ldots \ldots \ldots 4-42$

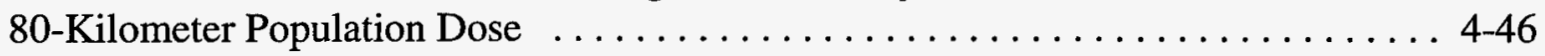

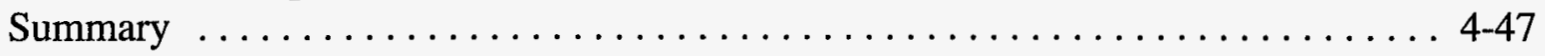

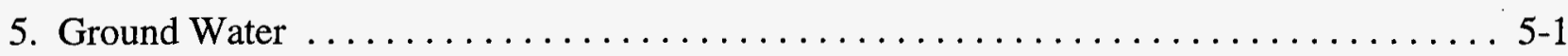

5.1 U.S. Geological Survey Program Information $\ldots \ldots \ldots \ldots \ldots \ldots \ldots \ldots \ldots . \ldots \ldots$

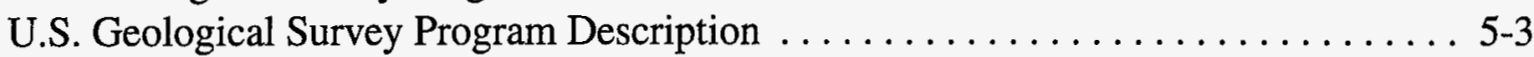

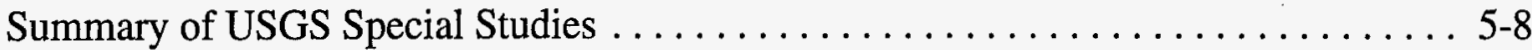

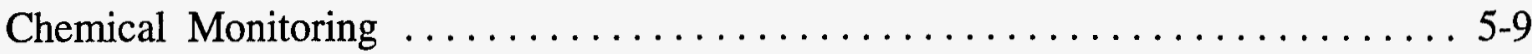

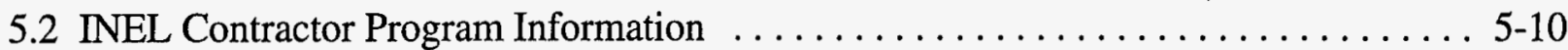

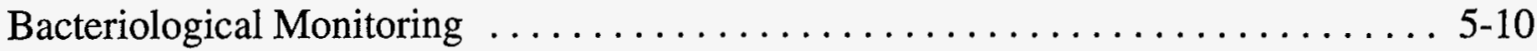

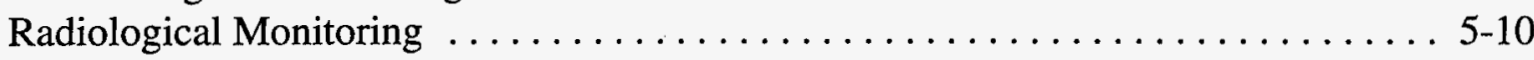

Chemical Monitoring $\ldots \ldots \ldots \ldots \ldots \ldots \ldots \ldots \ldots \ldots \ldots \ldots \ldots \ldots \ldots \ldots \ldots \ldots \ldots \ldots, 12$

6. Environmental Nonradiological Program Information $\ldots \ldots \ldots \ldots \ldots \ldots \ldots \ldots .6 .1$

6.1 Environmental Surveillance Program Description .................... 6-3

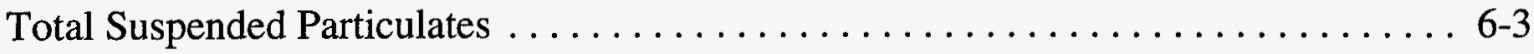

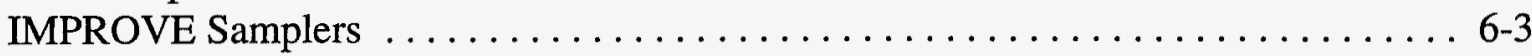

Nitrogen Dioxide/Sulfur Dioxide Monitoring $\ldots \ldots \ldots \ldots \ldots \ldots \ldots \ldots \ldots .6 .3$

6.2 Environmental Surveillance Program Results $\ldots \ldots \ldots \ldots \ldots \ldots \ldots \ldots \ldots$ 6 6 .4

Total Suspended Particulates . . . . . . . . . . . . . . . . . . . . . . . .

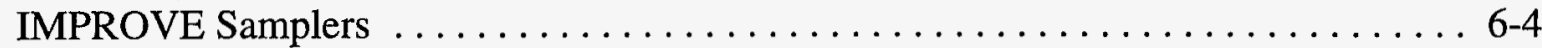

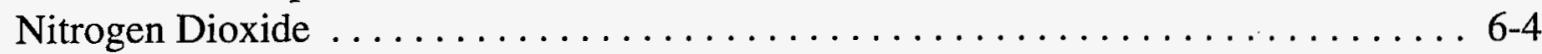

Sulfur Dioxide $\ldots \ldots \ldots \ldots \ldots \ldots \ldots \ldots \ldots \ldots \ldots \ldots \ldots \ldots \ldots \ldots \ldots \ldots \ldots \ldots$

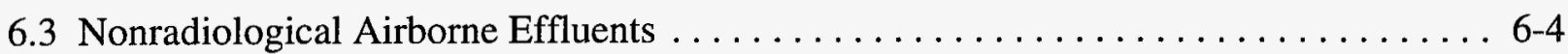

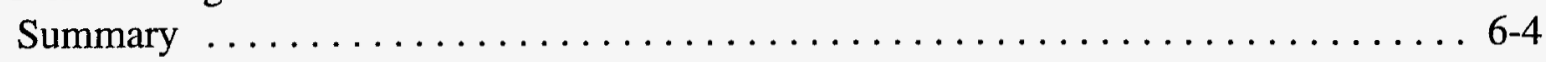

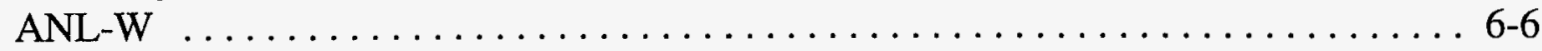

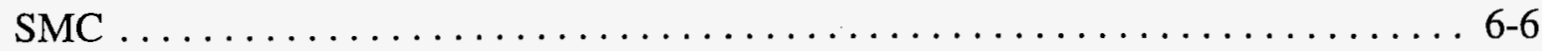

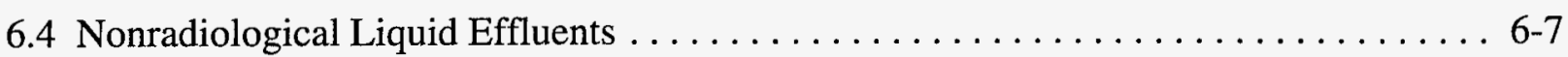

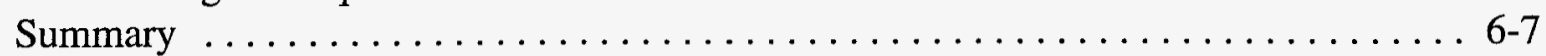

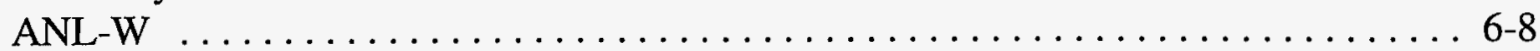




\section{CONTENTS (Cont.)}

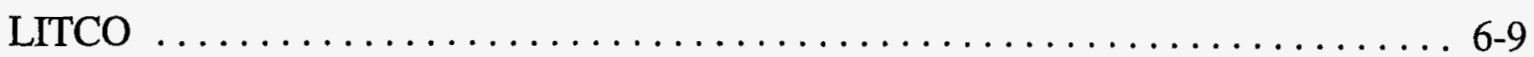

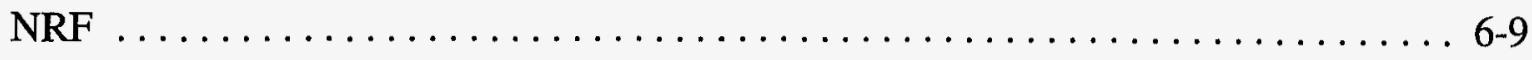

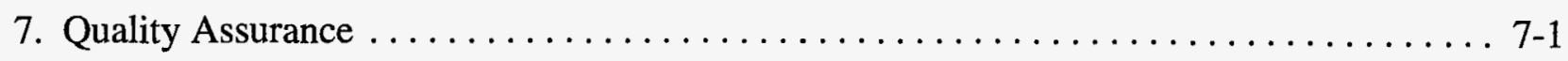

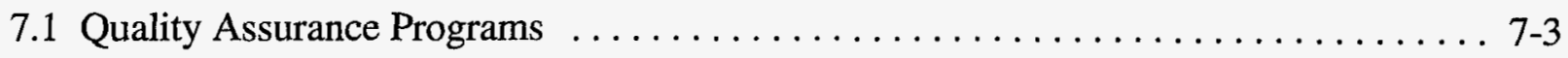

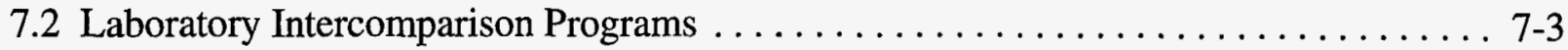

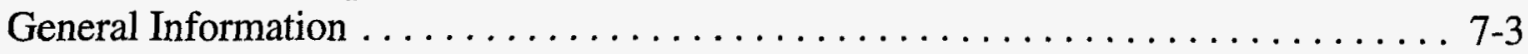

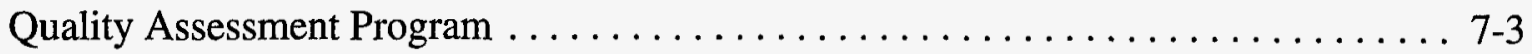

National Institute of Standards and Technology $\ldots \ldots \ldots \ldots \ldots \ldots \ldots \ldots \ldots .7-4$

Environmental Protection Agency Intercomparison Studies Program $\ldots \ldots \ldots \ldots .7-4$

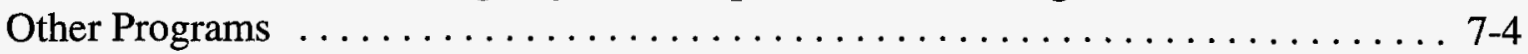

U.S. Geological Survey $\ldots \ldots \ldots \ldots \ldots \ldots \ldots \ldots \ldots \ldots \ldots \ldots \ldots \ldots \ldots \ldots \ldots \ldots \ldots, 4$

Dosimetry $\ldots \ldots \ldots \ldots \ldots \ldots \ldots \ldots \ldots \ldots \ldots \ldots \ldots \ldots \ldots \ldots \ldots \ldots \ldots \ldots \ldots, 4$

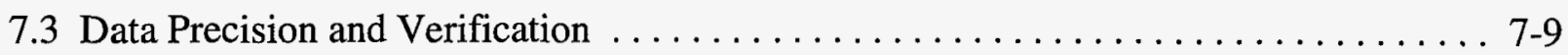

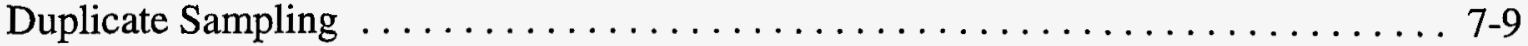

Independent Data Comparisons ........................... 7-9

Appendix A-Environmental Standards and Regulations $\ldots \ldots \ldots \ldots \ldots \ldots \ldots \ldots$ A-1

Appendix B—Statistical Methods Used for the Environmental Surveillance Program ....... B-1 


\section{FIGURES}

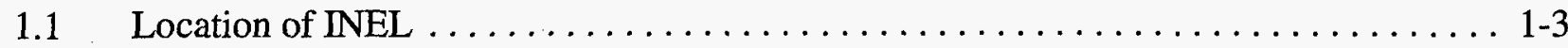

$1.2 \quad$ INEL Vicinity $\ldots \ldots \ldots \ldots \ldots \ldots \ldots \ldots \ldots \ldots \ldots \ldots \ldots \ldots \ldots \ldots \ldots \ldots \ldots \ldots \ldots \ldots \ldots, 1-5$

$1.3 \quad$ INEL Facilities $\ldots \ldots \ldots \ldots \ldots \ldots \ldots \ldots \ldots \ldots \ldots \ldots \ldots \ldots \ldots \ldots \ldots \ldots \ldots \ldots \ldots \ldots \ldots, 1-7$

3.1 Potential Pathways from the INEL to Humans $\ldots \ldots \ldots \ldots \ldots \ldots \ldots \ldots \ldots \ldots \ldots \ldots$

$4.1 \quad$ Low-Volume Air Sampler Locations $\ldots \ldots \ldots \ldots \ldots \ldots \ldots \ldots \ldots \ldots \ldots \ldots \ldots \ldots$

4.2 Water, Foodstuff, and Environmental Dosimeter Sampling Locations . . . . . . . . . . 4 4-7

4.3 Weekly Gross Beta Concentrations in Air (1995) .................. 4-12

4.4 Monthly Gross Beta Concentrations (1986-1995) ................... 4-13

4.5 Tritium Concentrations in INEL Production Wells $(1991-1995) \quad \ldots \ldots \ldots \ldots \ldots .4-22$

4.6 Environmental Dosimeter Measurements at ANL-W (1995). . . . . . . . . . . . . 4-30

4.7 Environmental Dosimeter Measurements at ARA (1995) ............... 4-30

4.8 Environmental Dosimeter Measurements at CFA (1995)................. 4-31

4.9 Environmental Dosimeter Measurements at ICPP (1995) . . . . . . . . . . . . . 4-31

4.10 Environmental Dosimeter Measurements at NRF (1995) . . . . . . . . . . . 4-32

4.11 Environmental Dosimeter Measurements at PBF (1995) . .............. 4-32

4.12 Environmental Dosimeter Measurements at RWMC (1995). ............. 4-33

4.13 Environmental Dosimeter Measurements at TAN (1995) ................ 4-34

4.14 Environmental Dosimeter Measurements at TRA (1995). .............. 4-34

4.15 Environmental Dosimeter Measurements along Lincoln Blvd.

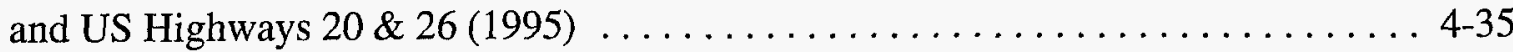




\section{FIGURES (Cont.)}

4.16 1995 Average of Mesoscale Dispersion Isopleths of Air Concentrations at Ground Level, Normalized to Unit Release Rate . . . . . . . . . . . . . . . . . . 4-41

4.17 Radionuclides Contributing to Maximum Individual Dose (1995) . . . . . . . . . 4-43

4.18 Radionuclides Contributing to Maximum Individual Dose (1991-1994) . . . . . . . 4-44

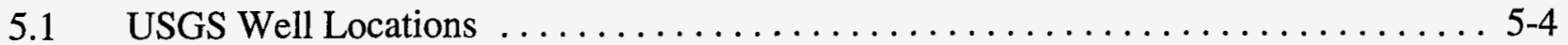

5.2 USGS Well Locations at ICPP-TRA and RWMC $\ldots \ldots \ldots \ldots \ldots \ldots \ldots \ldots$

5.3 Distribution of Tritium in the Snake River Plain Aquifer on the INEL, $1991 \ldots \ldots$. . . 5-6

5.4 Distribution of ${ }^{90} \mathrm{Sr}$ in the Snake River Plain Aquifer on the INEL, $1991 \ldots \ldots \ldots$. . . 5-7 


\section{TABLES}

2.1 INEL 1995 Emergency Planning and Community Right-to-Know Act Update $\ldots . . .2$ 2-4

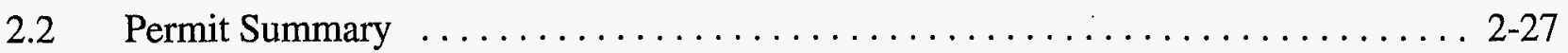

3.1 Foundation Environmental Surveillance Radiological Monitoring Program Summary (1995) ........................................... 3-34

3.2 LITCO Environmental Surveillance Radiological Program Summary (1995) . . . . . 3-35

3.3 USGS Ground-Water Monitoring Program Summary $\ldots \ldots \ldots \ldots \ldots \ldots \ldots$ 3-36

4.1 Gross Alpha Activity in Air (1995) . ...................... 4-10

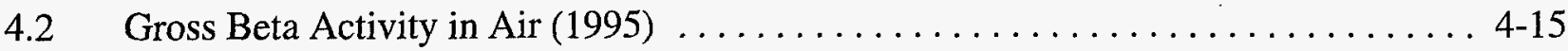

4.3 Statistical Comparison Table of Gross Beta Concentrations in Air at Distant,

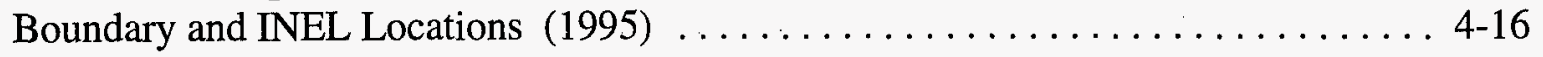

4.4 Manmade Radionuclides in Foundation Air Samples (1995) . . . . . . . . . . . 4 4-17

4.5 Manmade Radionuclides in LITCO Air Samples (1995) . . . . . . . . . . . . . 4-18

4.6 Tritium Concentrations in INEL Production Wells $(1995) \ldots \ldots \ldots \ldots \ldots \ldots$ 4-21

4.7 Strontium-90 Concentrations in ICPP Production Wells (1995) . . . . . . . . . . . 4-23

$4.8 \quad{ }^{90} \mathrm{Sr}$ Concentrations in Garden Lettuce $(1991-1995) \ldots \ldots \ldots \ldots \ldots \ldots \ldots \ldots .4 .24$

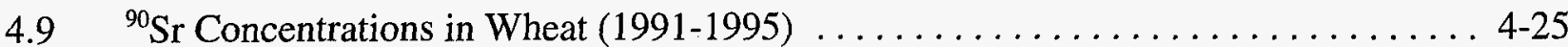

4.10 Manmade Gamma-emitting Radionuclides in Edible Portions of Waterfowl (1995) . . 4-26

4.9 Environmental Radiation Exposures $(1991-1995) \ldots \ldots \ldots \ldots \ldots \ldots \ldots \ldots \ldots$ 4-27

4.12 Estimated Natural Background Effective Dose Equivalent (1995) . . . . . . . . 4-28

4.13 Radionuclide Composition of Airborne Effluents (1995) ............... 4-37

4.14 Radionuclide Composition of Liquid Effluent Released Onsite (1995) . . . . . . . . 4-38

4.13 Maximum Individual Effective Dose Equivalent (1995) ............... 4-42 


\section{TABLES (Cont.)}

4.16 Individual Effective Dose Equivalent from Ingestion of Muscle Tissue of Waterfowl Using INEL Waste Disposal Ponds . . . . . . . . . . . . . . . . . . . . . 4 45

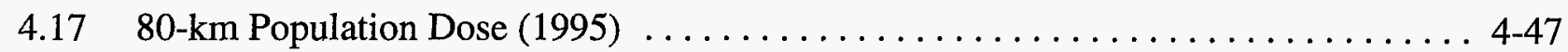

4.18 Summary of Annual Effective Dose Equivalents Due to INEL Operations (1995) _. 4-48

5.1 Purgeable Organic Compounds in USGS Well Samples (1995) ........... . 5-11

5.2 Regulated Organic Compounds $[\mu \mathrm{g} / \mathrm{L}]$ in INEL Drinking Water (1995) $\ldots \ldots \ldots$ 5-13

5.3 Inorganic Chemicals in ICPP Potable and Production Wells (1995) . . . . . . . . 5-14

6.1 Particulate Matter Concentrations in Air (1995) $\ldots \ldots \ldots \ldots \ldots \ldots \ldots \ldots$ 6-5

6.2 Ten-Year Summary of Particulate Matter Concentrations (1986-1995) . . . . . . . 6-6

6.3 Data for IMPROVE Samplers at CFA and Craters of the Moon National Monument (September 1994-August 1995) ........................... 6-7

6.4 Summary of $\mathrm{NO}_{2}$ and $\mathrm{SO}_{2}$ Emissions and Ambient Monitoring

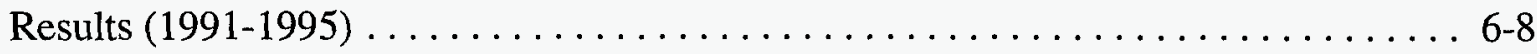

6.5 TRA Liquid Effluent Inorganic Monitoring Data (1995) $\ldots \ldots \ldots \ldots \ldots \ldots$ 6-10

6.6 ICPP Service Waste Inorganic Monitoring Data (1995) $\ldots \ldots \ldots \ldots \ldots \ldots$ 6-11

7.1 Environmental Measurements Laboratory Quality Assessment Program Results For Radiological Measurements Laboratory (1995) $\ldots \ldots \ldots \ldots \ldots \ldots \ldots \ldots$ 7-5

7.2 DOE Environmental Measurements Laboratory Quality Assessment Program Results Comparison For INEL Research Center (1995) . . . . . . . . . . . . . . . . 7-6

7.3 DOE Environmental Measurements Laboratory Quality Assessment Program Results Comparison For Radiological and Environmental Sciences Laboratory (1995) . . . . . 7-7

7.4 DOE Environmental Measurements Laboratory Quality Assessment Program Results

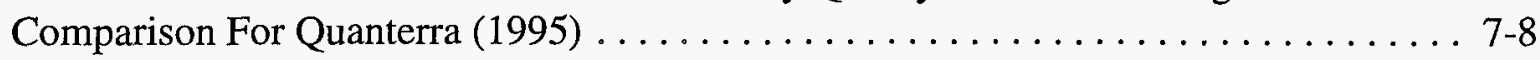

7.5 Comparison of Duplicate Air Monitoring Results (1995) .............. 7-10 


\section{TABLES (Cont.)}

7.6 Comparison of Foundation, LITCO and State of Idaho Air Monitoring Results

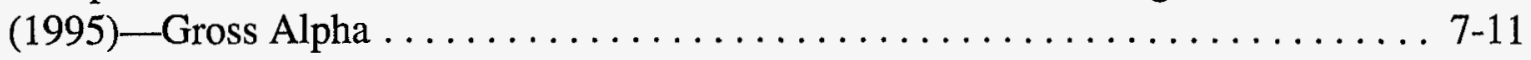

7.7 Comparison of Foundation, LITCO and State of Idaho Air Monitoring Results (1995)-Gross Beta .................................. 7-12

7.8 Comparison of Foundation and State of Idaho Water Monitoring Results (1995) . . . 7-13

I Derived Concentration Guides for Radiation Protection $\ldots \ldots \ldots \ldots \ldots \ldots \ldots$ A-2

II Radiation Standards for Protection of the Public in the Vicinity of DOE Facilities . . . A-3

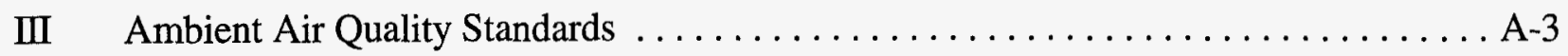

IV Maximum Contaminant Levels for Nontransient Noncommunity Drinking

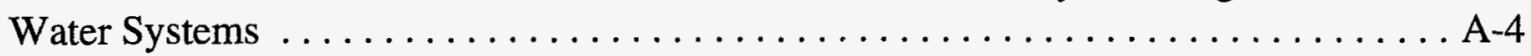




\section{LIST OF REPORT CONTRIBUTORS}

The following people contributed data, information, and/or writing to this report:

LITCO Environmental Monitoring Information

Bob Bates, Kelly Wright, Bryan Borsella, Maria Miles, Curtiss Peterson

Effluent Data Karen Taylor, Dan Lisée, Joan Neff Meteorological Information $\ldots \ldots \ldots \ldots \ldots \ldots \ldots \ldots \ldots \ldots \ldots$ Jerrold Sagendorf NESHAPs/CAP-88 Paul Ritter

Game Ingestion Pathway Ron Warren USGS Information Brennon Orr, Betty Tucker, Roy Bartholomay

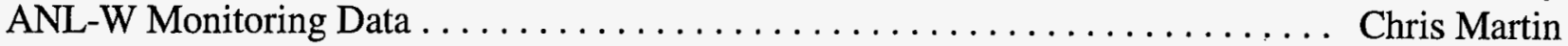

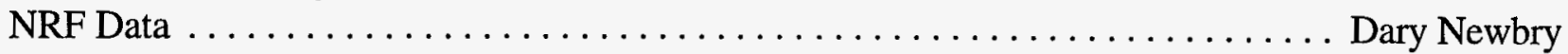
INEL Drinking Water Data ........... Brad Andersen, Maurice McLain, Teresa Meachum Specific Manufacturing Capability Facility Information ............... Hal Jackson Laboratory Intercomparison Data Havis Harrison State of Idaho Oversight Program Monitoring Data Flint Hall, Doug Walker 


\section{Chapter 1. INTRODUCTION}

\section{Chapter Summary}

The Idaho National Engineering Laboratory (INEL), located on $2,300 \mathrm{~km}^{2}\left(890 \mathrm{mi}^{2}\right)$ of the Snake River Plain in southeastern Idaho, is a U.S. Department of Energy facility established for the purpose of developing and testing nuclear reactors. Today, the INEL is performing research in the areas of environmental management, spent nuclear fuel, mixed waste characterization and treatment, advanced manufacturing, and transportation technologies. This chapter presents a brief history of the INEL and provides a physical description of its geology, biology, and meteorology (Section 1.1). Major ongoing missions and programs, and facilities located at the INEL, are also described (Section 12).

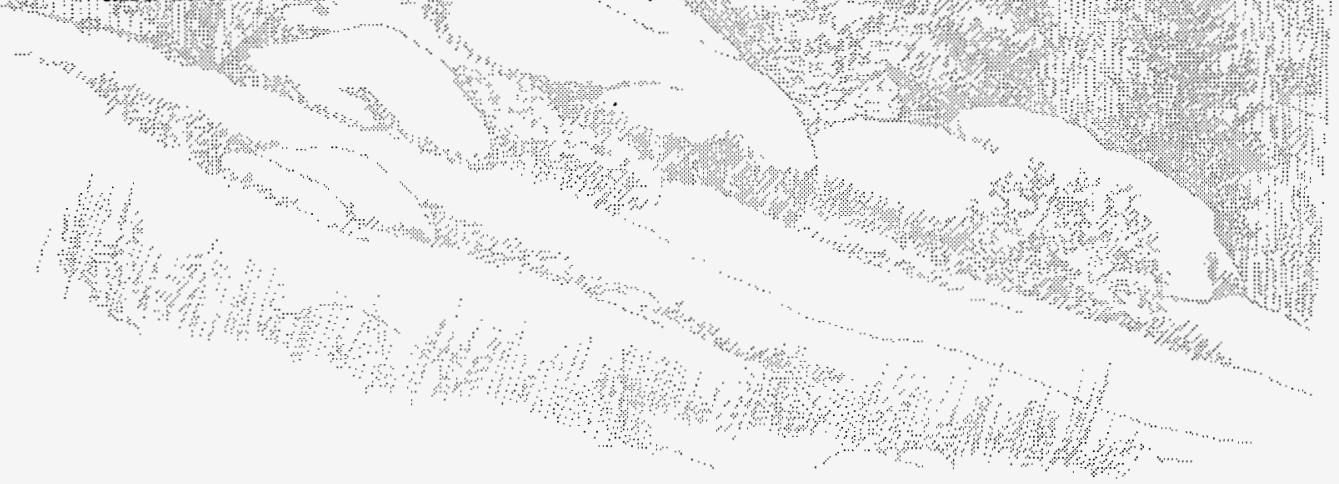




\section{INTRODUCTION}

\subsection{SITE DESCRIPTION}

\section{History}

The Idaho National Engineering Laboratory (INEL) of the U.S. Department of Energy (DOE) was established as the National Reactor Testing Station on the southeastern Idaho desert in 1949 to conduct research and further the development of nuclear reactors (Figure 1.1). Prior to that time, the area was known as the Naval Proving Grounds and was used as a testing range for naval guns from the U.S. Naval Ordnance Station in Pocatello, Idaho.

The first reactor built at the INEL, the Experimental Breeder Reactor-I, achieved initial criticality in December 1951. The INEL expanded rapidly in the 1950s with the establishment of the Test Reactor Area, the Naval Reactors Facility, and the Idaho Chemical Processing Plant, and with the development of the Aircraft Nuclear Propulsion program at the current Test Area North. In July 1955 , one of the reactors at the INEL became the first to light an American town (Arco, Idaho).

In 1974, the name was changed from the National Reactor Testing Station to the INEL to better reflect current projects, which include non-nuclear as well as nuclear projects. To date, 52 reactors have been built at the INEL.

\section{Physical Description}

The INEL is situated on the eastern Snake River Plain in southeastern Idaho at an average elevation of $1,500 \mathrm{~m}(4,900 \mathrm{ft})$. The INEL encompasses $2,300 \mathrm{~km}^{2}\left(890 \mathrm{mi}^{2}\right)$, extends 63

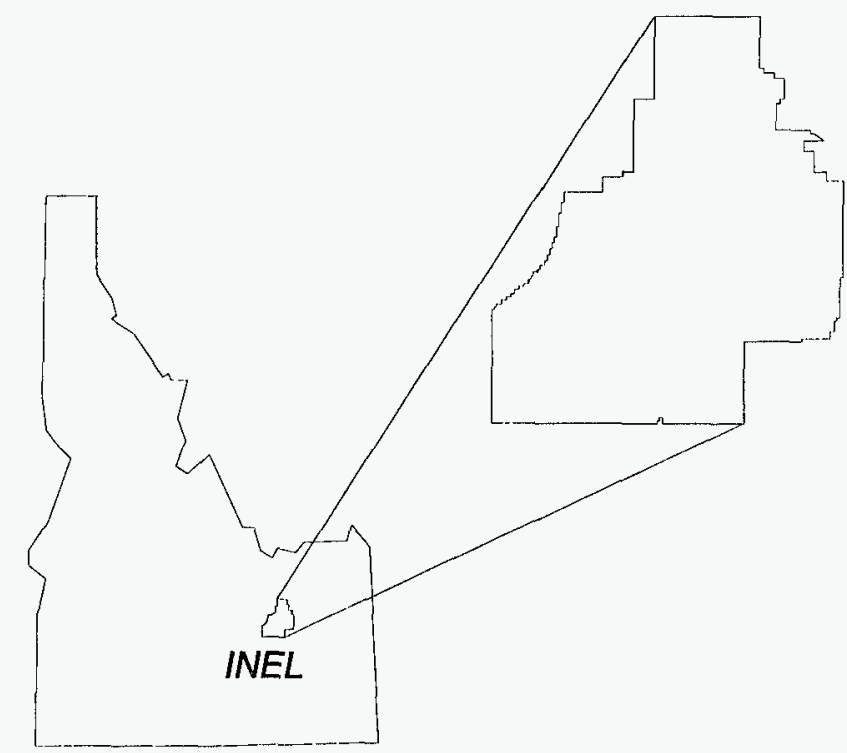

Figure 1.1 Location of INEL

$\mathrm{km}$ (39 mi) from north to south and is about 58 $\mathrm{km}(36 \mathrm{mi})$ wide at its broader southern part. Land immediately beyond the boundaries of the INEL is either desert, foothills, or agricultural fields. Most of the nearby farming is concentrated northeast of the INEL. Large areas of agricultural land are farmed adjacent to the Snake River, but these regions are more distant from the INEL.

The plain where the INEL is located is part of a cool, desert-shrub biome. Vegetation is typical of the Great Basin, with sagebrush conspicuous over $80 \%$ of the INEL.

The surface of the eastern Snake River Plain is composed of a sequence of basaltic lava flows extruded over the past two million years. Sedimentary deposits, including gravel and sand deposited by streams (as alluvial fans, channel fillings, and deltas), windblown and, and silt and clay deposited in playa lakes occur as interbeds between lava flows and cover the 
flows in many locations. An ancient lake, known as Lake Terreton, covered approximately $233 \mathrm{~km}^{2}\left(35 \mathrm{mi}^{2}\right)$ of the northern INEL during the last glacial period ${ }^{\mathrm{a}}$.

Underlying the plain is the Snake River Plain Aquifer. Ground-water underflow from the area near Henry's Fork of the Snake River supplies a significant amount of water to the Snake River Plain Aquifer beneath the INEL. Additional recharge to the aquifer comes from the Big and Little Lost Rivers and Birch Creek drainages. These streams originate in the mountains to the northwest of the INEL. The Big Lost River and Birch Creek flow onto the INEL during portions of wet years and sink into the porous soils. The underground water moves laterally at an average rate of 1.5 to $6 \mathrm{~m} / \mathrm{d}$ (5 to $20 \mathrm{ft} / \mathrm{d}$ ) to the south and west, and emerges in springs along the Snake River between Milner and Bliss, Idaho. Discharge volumes from typical springs in this region are approximately $4.3 \times 10^{9} \mathrm{~m}^{3}\left(3.5 \times 10^{6}\right.$ acre-ft) per year. Both the ground and surface waters of the Snake River Plain are used for crop irrigation.

Average annual temperature at the INEL Central Facilities Area is $5.6^{\circ} \mathrm{C}\left(42^{\circ} \mathrm{F}\right)$, with extremes of $38^{\circ} \mathrm{C}\left(101^{\circ} \mathrm{F}\right)$ and $-44^{\circ} \mathrm{C}\left(-47^{\circ} \mathrm{F}\right)$. Annual precipitation in the area has averaged 22 $\mathrm{cm}$ (8.7 in) over the past 15 years, peaking in late spring. Winds are predominantly along the southwest-northeast axis of the plain, with the most frequent and strongest winds from the southwest. The northeast winds are mostly nocturnal. Spring is the windiest time of the year, while winter has more calm periods and more nighttime temperature inversions ${ }^{\mathrm{b}}$.

\footnotetext{
2 S.J. Miller, INEL Management Plan for Cultural Resources, DOE/ID10361, March 1993.

b K.L. Clawson, G.E. Start, and N.R. Ricks, Climatography of the Idaho National Engineering Laboratory, 2nd Edition; DOE/ID-12118, December 1989.
}

The nearest INEL boundaries are $35 \mathrm{~km}(22$ mi) west of Idaho Falls, $37 \mathrm{~km}(23 \mathrm{mi})$ northwest of Blackfoot, $71 \mathrm{~km}(44 \mathrm{mi})$ northwest of Pocatello, and $11 \mathrm{~km}(7 \mathrm{mi})$ east of Arco, Idaho (Figure 1.2). With a population of about 1,100, Arco is the largest boundary community in the area surrounding the INEL. Atomic City (population 25) is the closest boundary community ${ }^{c}$. Approximately 121,500 people reside within a radius of $80 \mathrm{~km}(50 \mathrm{mi})$ of the INEL's operational center (Figure 1.3). There are no residents within $16 \mathrm{~km}(10 \mathrm{mi})$ of that center.

\subsection{INEL MISSION AND FACILITIES}

\section{Mission}

According to the Department of Energy Mission Statement, the present mission of the INEL is to develop, demonstrate, deploy, and transfer advanced engineering technology and systems to private industry to improve U.S. competitiveness and security, the efficient production and use of energy, and the quality of life and the environment worldwide.

\section{Facilities}

The Idaho National Engineering Laboratory is operated for the U.S. Department of Energy by Lockheed Idaho Technologies Company. Additional facilities are operated by Westinghouse Electric Corporation and the University of Chicago's Argonne National Laboratory. Facilities are located in the city of Idaho Falls and at eight operating areas on

\footnotetext{
1990 Census.
} 


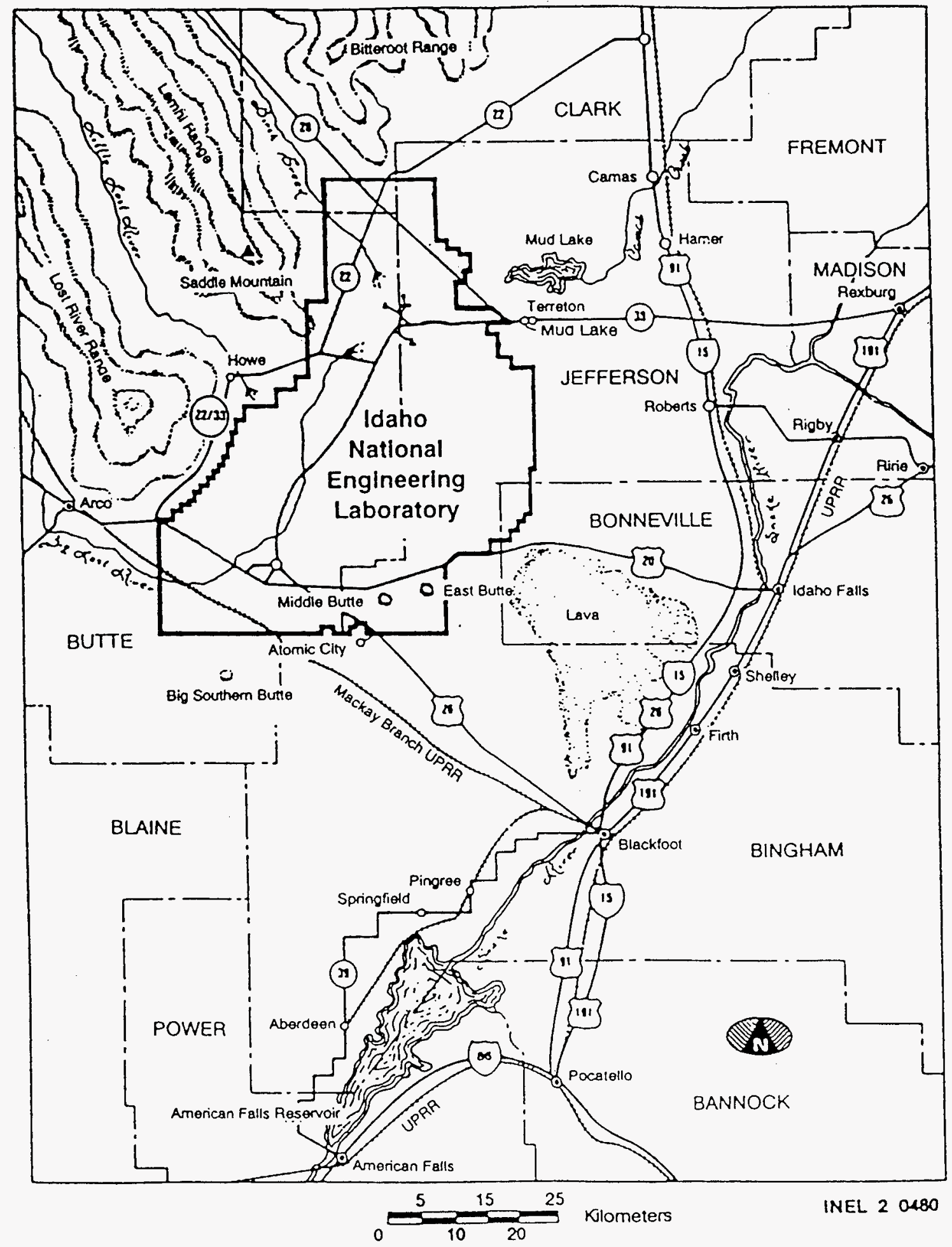

Figure 1.2 INEL Vicinity 
the INEL (Figure 1.3). Major facilities, and their current missions, are listed in the following sections.

\section{Argonne National Laboratory-West} (ANL-W). This facility is operated by the University of Chicago's Argonne National Laboratory under contract to the DOE-Chicago Operations Office (DOE-CH). At this site, ANL-W developed the Integral Fast Reactor, a new generation of breeder reactor that has advantages in safety and waste reduction. This project was terminated by Congress during 1995. The present mission of the laboratory is research into areas of national concern, including spent nuclear fuel, nuclear proliferation, and waste reduction and cleanup technologies.

Idaho Chemical Processing Plant (ICPP). The ICPP receives and stores nuclear fuels from the U.S. Navy and other activities. Technologies for treatment and disposal of high-level waste are being developed at the plant. High-level wastes are being treated and will ultimately be prepared for disposal in a permanent repository.

Test Area North (TAN). Located at the north end of the INEL, TAN was built to house the program to develop a nuclear-powered airplane during the 1950s. Facilities include one of the world's largest "hot shops," which more recently supported research into the Three Mile Island accident. The largest program currently at TAN, the Specific Manufacturing Capability Project, produces armor for the M1A2 Abrams tank for the U.S. Army.

Test Reactor Area (TRA). The TRA has studied the effects of radiation on materials, fuels, and equipment for nearly 40 years. The
Advanced Test Reactor is currently used for the production of important isotopes used in medicine, research, and industry.

Power Burst Facility (PBF). The PBF area contains the Waste Experimental Reduction Facility (WERF), which processes low-level waste to reduce waste volume through sizing of metallic waste and compaction. The PBF reactor is now being researched for its potential use in brain cancer treatments for the Boron Neutron Capture Therapy program.

Naval Reactors Facility (NRF). The NRF is operated by Westinghouse Electric Corporation for DOE's Pittsburgh Naval Reactors Office. From 1953 through May 1995, NRF prototypes served as a site for training Navy personnel who serve aboard nuclear-powered submarines and warships. At the Expended Core Facility, NRF also tests and examines naval reactor fuel components to improve current designs and to monitor the performance of existing reactors.

\section{Radioactive Waste Management Complex} (RWMC). The RWMC's mission is to manage the disposal of low-level radioactive waste and the temporary storage of transuranic waste in an environmentally sound manner. The facility studies various high-technology strategies for the storage, processing and disposal of radioactive wastes. The Stored Waste Examination Pilot Plant is used to nondestructively examine waste before it can be sent to the Waste Isolation Pilot Plant in New Mexico.

Central Facilities Area (CFA). The CFA is a headquarters for services at the INEL. The area contains environmental monitoring and calibration laboratories, vehicle and equipment pools, a cafeteria, warehouses, and a security facility. 
Idaho Falls. Idaho Falls facilities include the INEL Research Center, featuring programs in materials science, physical science, biotechnology, environmental science, and geotech- nology. The Engineering Research Office Building and the Willow Creek Building house support personnel for the facilities at the INEL ${ }^{\text {a }}$.

* INEL Worldwide Web page, http://www.inel.gov

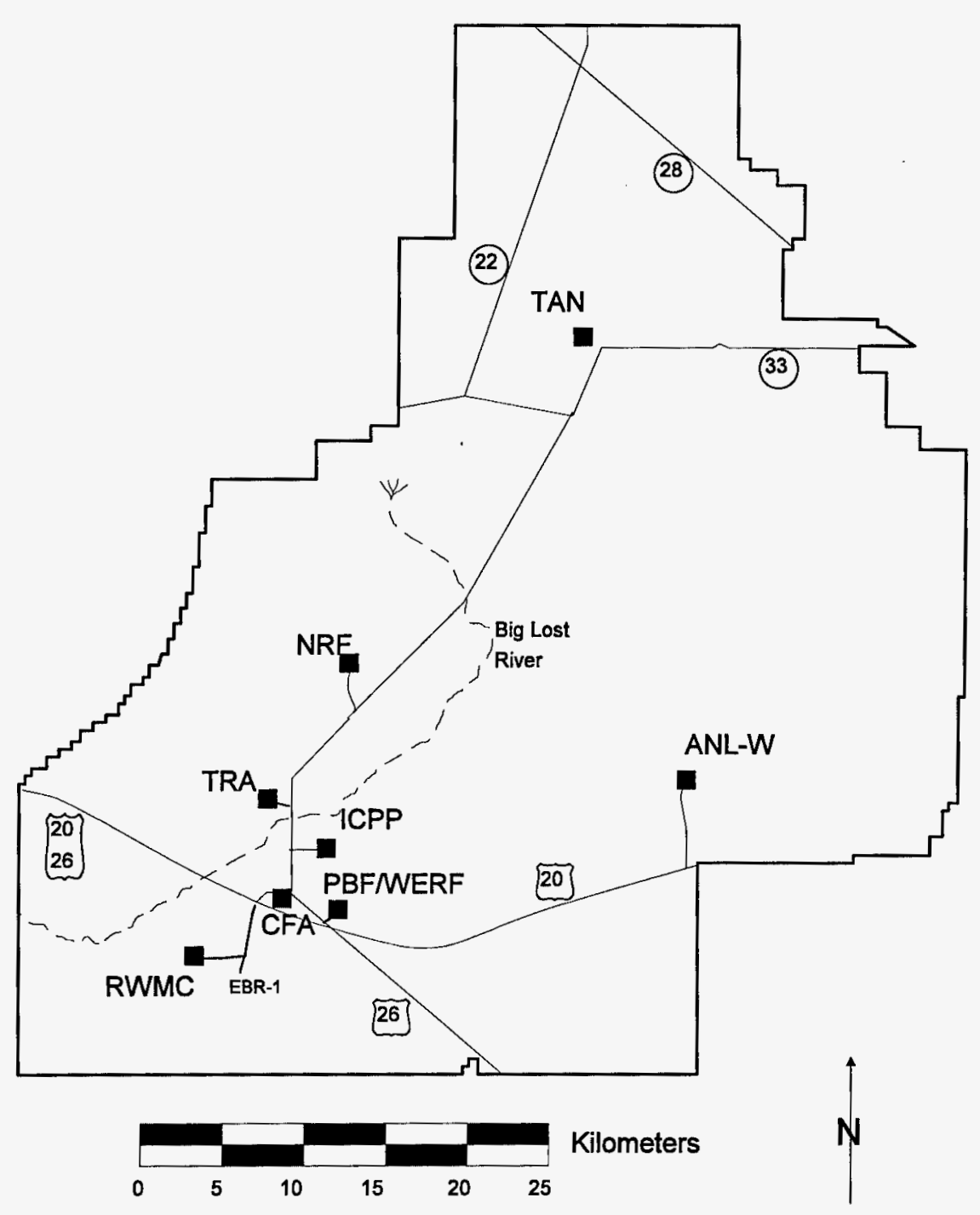

Figure 1.3 INEL Facilities 


\section{Chapter 2. ENVIRONMENTAL}

\section{COMPLIANCE SUMMARY}

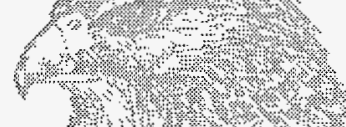

Chapter Summary

The Idaho National Engineering Laboratory (MNU) is committed to operating in compliance with all environmental laws, regulations, Executive Orders, DOE Orders, and compliance agreements with the Envirommental Protection Agency (EPA) and the State of Idaho. This Chapter provides a summary of the INEL's current compliance status with major environmental statutes for the period January through December 1995 (Secter 21), and summarizes najor environmental issues and activities (Section 22). The current status of various permits are also described in this chapter (Section 2.3).

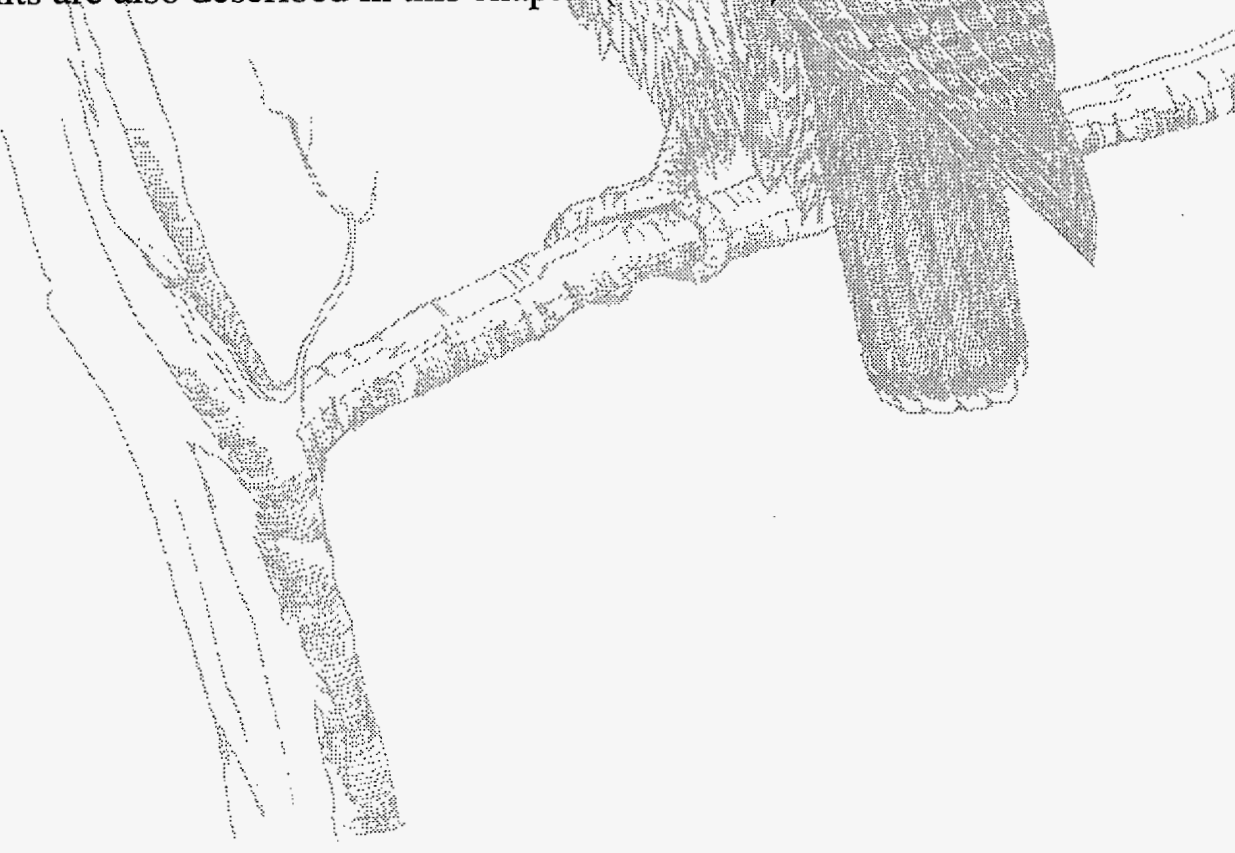




\section{ENVIRONMENTAL COMPLIANCE SUMMARY}

\subsection{COMPLIANCE STATUS}

\section{Comprehensive Environmental Response, Compensation \& Liability Act (CERCLA)}

This Act provides the specific procedures to be used to assess and remediate inactive waste sites where the release of hazardous substances has occurred. The INEL was placed on the National Priorities List under CERCLA on November 29, 1989. Environmental restoration activities at the INEL are being conducted in accordance with the 1991 Federal Facility Agreement and Consent Order signed by DOEID, the State of Idaho, and EPA Region 10.

During 1995, investigations under the processes outlined in the Consent Order continued to be streamlined. Limited field investigations, termed Track 1 or Track 2, were used in lieu of the more extensive Remedial Investigation/Feasibility Study to evaluate many potential release sites. A Track 1 designation is used for potential release sites where existing data are expected to be able to demonstrate that a site needs no further action. Track 2 denotes that limited field data collection is necessary. After each limited investigation is completed, a determination is made by the Consent Order Project Managers that no further action is necessary or that proceeding with an interim cleanup action or further investigation under a Remedial Investigation/Feasibility Study is appropriate. The INEL met $100 \%$ of all Federal Facility Act/Consent Order enforceable milestones ahead of schedule in 1995.

CERCLA Continuous Release Report. In 1995, the INEL filed a continuous release report with the National Response Center for cyclohexylamine at the INEL. The Reportable
Quantity was set at $454 \mathrm{~g}(1 \mathrm{lb})$ until July 1, 1996. EPA set a new Reportable Quantity of $2,270 \mathrm{~kg}(5,000 \mathrm{lb})$ that became effective on that date. INEL releases are well below the new level.

\section{Emergency Planning and Community Right- to-Know Act (EPCRA)}

The purposes of this Act are to provide the public with information about hazardous chemicals on the INEL and to establish emergency planning and notification procedures to protect the public from chemical releases. It also contains requirements for periodic reporting on hazardous chemicals stored and/or used at the facilities. Executive Order 12856, "Federal Compliance with Right-to-Know Laws and Pollution Prevention Requirements," requires all federal facilities to comply with the provisions of this Act (Table 2.1).

311 Report. Quarterly 311 reports were submitted to the Local Emergency Planning Committees, the State Emergency Response Commission, and to local fire departments by January 1, April 1, July 1, and October 1 in 1995. These quarterly reports satisfy the 90-day notice requirement for new chemicals brought onsite.

312 Report. The Emergency and Hazardous Chemical Inventory (Tier II) Report for 1995 was transmitted to the planning and response agencies before March 1, 1996. These annual reports identify the types, quantities, and locations of hazardous and extremely hazardous chemicals, stored at INEL facilities, which exceed the CERCLA and EPCRA reporting thresholds. 


\section{TABLE 2.1}

\section{INEL 1995 EMERGENCY PLANNING AND COMMUNITY} RIGHT-TO-KNOW ACT UPDATE

EPCRA 302-303: Planning Notification

EPCRA 304: EHS Release Notification

EPCRA 311-312: MSDS ${ }^{\text {a }}$ Chemical Inventory

EPCRA 313: TRI Reporting
Yes [X] No [ ] Not Required [ ]

Yes [X] No [ ] Not Required [ ]

Yes [X] No [ ] Not Required [ ]

Yes [X] No [ ] Not Required [ ]

${ }^{a}$ Material Safety Data Sheet

313 Report. The Toxic Chemical Release Inventory Report was transmitted to EPA and the State of Idaho by July 1, 1995. The report identified quantities of toxic chemicals that were released to the environment by the INEL during calendar year 1994. Reports were prepared for seven toxic chemicals: benzene, methyl isobutyl ketone, methyl tertiary-butyl ether, nitric acid, sulfuric acid, toluene, and xylene in 1995.

33/50 Report. Executive Order 12856 requires all Federal Agencies to comply with the EPA $33 / 50$ program, requiring release reductions of 17 priority Toxic Chemical Release Inventory chemicals by $50 \%$ before the end of 1999 . On March 27, 1995, EPA made the 1993 Toxic Chemical Release Inventory numbers available to the public, including DOE's data. Total toxic chemical releases to the environment at the INEL in 1993 were about $160,000 \mathrm{~kg}(360,000$ lb). The INEL filed a Toxic Release Inventory report in 1993 for one priority chemical, methyl isobutyl ketone.

In 1994 the INEL reported four priority chemicals, methyl isobutyl ketone and three components of gasoline (benzene, xylene, and toluene) which were reported for the first time. In 1995 only the latter three were reportable for the INEL.

\section{Natural Resource Trusteeship \& Natural Resources Damage Assessment}

Executive Order 12580, Section 2(d), appoints the Secretary of Energy as the primary Federal Natural Resource Trustee for natural resources located on, over, or under land administered by DOE. Natural resource trustees act on behalf of the public when natural resources may be injured, destroyed, lost, or threatened as a result of the release of hazardous substance. Federal agencies, states, and Native American tribes are designated as natural resource trustees by National Contingency Plan Sections 300.600(b), 300.605, and 300.610, respectively. In the case of the INEL other potential natural resource trustees with possible jurisdiction over trust resources are the State of Idaho, Department of Interior (Bureau of Land Management and U.S. Fish and Wildlife Service), and Shoshone-Bannock Tribes.

Past releases of hazardous substances resulted in the INEL's placement on the National Priorities List. These same releases create the potential for injury to natural resources. DOE is liable under CERCLA for damages to natural resources resulting from releases of hazardous substances to the environment. The Environmental Restoration 
Program is attempting to coordinate with DOEID co-trustees any INEL Natural Resource Damage Assessment issues arising as a result of the Comprehensive Remedial Investigation/ Feasibility Study for each Waste Area Group.

In April 1995, LITCO published document INEL-95/0190, Guidance Manual for Conducting Screening Level Ecological Risk Assessments at the INEL. This manual was developed to streamline and standardize the ecological assessment process at the INEL, and it supports the DOE schedules and milestones in the Federal Facility Agreement and Consent Order for carrying out remedial investigation/ feasibility study activities at the INEL. Integrating the natural resource concerns with these activities will lead to more efficient efforts and more cost-effective remediation of sites at the INEL. Although the ecological risk assessment is a separate effort from the Natural Resources Damage Assessment, it is anticipated that the ecological assessment performed for CERCLA remedial actions can be used to help resolve many natural resource issues among trustees as well. The regulation at $43 \mathrm{CFR}$ Part 11 allows this substitution ${ }^{\mathrm{a}}$.

A meeting with DOE-ID's co-trustees is scheduled for May 1996. Even though the meeting is later than would have been optimum for two remedial investigation/feasibility studies that are already underway, DOE-ID will coordinate and address issues on these projects. For future Waste Area Group investigations, coordination will be at the planning stage.

\section{Clean Air Act}

The Clean Air Act sets standards for ambient air quality and for air emission of hazardous air pollutants. EPA is the federal regulatory agency of authority, but states may

\footnotetext{
a DOE, Natural Resource Trusteeship and Ecological Evaluation for Environmental Restoration at Department of Energy Facilities, DOE/EH-0192, June 1991.
}

administer and enforce provisions of the Act by obtaining EPA approval of a State Implementation Plan.

A Permit to Construct may be required for any construction or modification of a facility that emits an air pollutant. Projects at the INEL that will result in emissions exceeding certain regulatory levels (i.e., major modifications) require Prevention of Significant Deterioration/ Permits to Construct. Applications for these permits require a more extensive analysis of the air pollutant emissions impacts.

Title V Operating Permit. Title V of the 1990 Clean Air Act Amendments required the EPA to develop a federally enforceable operating permit program for air pollution sources to be administered by the state and/or local air pollution agencies. The EPA established regulations in July 1992 that defined requirements for state programs. Idaho has now promulgated its own regulations presently being reviewed by EPA.

A Title $\mathrm{V}$ work group, consisting of DOEID and contractor representatives at the INEL, was established to develop the Title V Permit application. The application was a four-year effort beginning with the initiation of the INEL emissions inventory of the entire Site to quantify emissions from all sources. This inventory provides the basis for the Title $\mathrm{V}$ application. The updated Air Emission Inventory for the Idaho National Engineering Laboratory, which included both criteria and toxic air pollutant inventories, was sent to the State in June of 1994 and will be updated annually.

The Title V Air Operating Permit Application was submitted to the State Division of Environmental Quality (DEQ) July 28, 1995. The joint application for NRF and ANL-W was certified and signed by their responsible officials. The DOE/LITCO respective volumes were 
not certified due to an unresolved issue related to the LITCO contract with DOE-ID.

A letter received from the State of Idaho in October 1995 provided formal notification of incompleteness for the INEL Air Operating Permit. The application was deemed incomplete because it was not yet signed and certified for INEL facilities operated by LITCO and not all generally applicable requirements were listed. All review by the State on the application stopped at the end of November, and the INEL was allowed 30 days to sign the application and the compliance certifications, after which DEQ would resume processing the permit application. Final certification of the INEL Tier I Air Operating Permit Application was forwarded to DEQ the first week in December following extended negotiations with LITCO.

A letter to DOE-ID dated December 22, 1995, declared the permit application "administratively complete." This completes a major milestone and sets the stage for actual permit issuance scheduled for November 1998. The application allows the INEL to operate under the stated conditions until the actual operating permit is issued. The State has three years to issue the final permit.

WERF Opacity Monitoring. LITCO told DOE-ID that they planned to remove the opacity monitor for the WERF incinerator offgas monitoring system, and they requested approval for this action. DOE-ID concurred with the action. Involved in this issue is a regulatory requirement in the WERF Permit to Construct that visible emissions not exceed $5 \%$ opacity for more than three minutes in any 60minute period.

Air Permitting vs. Environmental Restoration (CERCLA) Activities. Discussions are continuing both within the INEL and among the agencies as to the relationship of CERCLA and the Clean Air Act, specifically air permitting. Clearly, CERCLA activities are not required to obtain air permits but are required to meet the substantive requirements of permits. However, CERCLA activities could impact other INEL sources via impacts to the ambient air quality (National Ambient Air Quality Standards and Prevention of Significant Deterioration Increments). An analysis of ambient air quality impacts of CERCLA activities would normally include the proposed action in addition to the existing, permitted sources. An agreement with the State for Pit 9 work at RWMC allows the portion of PSD analysis applying to Pit 9 to be done independently of the sitewide analysis. The sitewide analysis will then be performed by the Management and Operations contractor.

Any potential impacts to the environment via releases of radiological materials during CERCLA activities are included each year in the NESHAPs annual report.

Fuel Storage Area permit. The October 1995 agreement between DOE, the Navy, and the State of Idaho related to spent nuclear fuel shipments to Idaho and temporary storage at the INEL allows installation of the new fuel racks for the reconfiguration project upon receipt of a Permit to Construct from the State. The State held a public comment period between January 18 and February 16, 1996. The Permit to Construct for the Fuel Storage Area Rack Reconfiguration Project was received from the State of Idaho in April 1996.

Procurement of the new fuel storage racks for the Fuel Storage Area facility proceeded, and racks for this project have been received and are stored at ICPP. The new racks, which are $1.5 \mathrm{~m}(5 \mathrm{ft})$ taller than the existing racks, will increase and optimize the underwater storage capacity of fuel at ICPP. 
Chapter 2: Environmental Compliance Summary

National Emission Standards for Hazardous Air Pollutants (NESHAPs)

In June 1995, DOE-ID submitted the 1994 INEL National Emission Standards for Hazardous Air Pollutants-Radionuclides report to EPA, DOE Headquarters, and State of Idaho officials. Using the CAP-88 computer model, the hypothetical maximum individual effective dose equivalent to a member of the public resulting from 1994 INEL airborne radionuclide emissions (monitored, unmonitored, and diffuse sources) was $0.004 \mathrm{mrem} / \mathrm{yr}\left(4 \times 10^{-5} \mathrm{mSv} / \mathrm{yr}\right)$. This dose was $0.04 \%$ of the regulatory standard of $10 \mathrm{mrem} / \mathrm{yr}$.

The 1995 calculations with this code are discussed in Chapter 4, "Environmental Radiological Program Information."

In addition to the radiological NESHAPs program, LITCO operates an asbestos program. All renovations that involve asbestos or demolitions of any structure must satisfy requirements of 40 CFR 61, Subpart M. During the calendar year 1995 , there were 148 renovation operations involving nonscheduled operations in which amounts were less than the EPA threshold; and there were 34 scheduled renovation or demolition operations that required EPA notifications (amounts above the EPA threshold).

\section{Clean Water Act}

The Clean Water Act, originally passed in 1972, established goals to control pollutants discharged to U.S. surface waters. Among the main elements of the Act were effluent limits set by the EPA for specific industry categories and water quality standards set by states. The Clean Water Act also provided for the National Pollutant Discharge Elimination System (NPDES) permit program, requiring permits for discharges from a point source into surface waters. An expansion of the NPDES was instituted with the issuance of storm water discharge permits to medium and large municipalities and sites with industrial activity.

Waters of the United States Delineation. In 1992, areas on the INEL that are potential "Waters of the United States" were mapped and presented to EPA Region 10 and the Army Corps of Engineers. These areas encompass what is called the Big Lost River system, which includes the Little Lost River, Birch Creek, the Big Lost River, and connecting tributaries and playas. In November 1993, the Army Corps of Engineers also designated the INEL Spreading Areas A and B near RWMC as Waters of the United States.

Clean Water Act Section 404 Permits. DOE-ID sent a joint request in May 1994 to the U.S. Army Corps of Engineers and the Idaho Department of Water Resources for a Clean Water Act Section 404 permit to authorize work in Spreading Area B near the Radioactive Waste Management Complex. Spreading Area $\mathrm{B}$ is one of four depressions where water is diverted from the Big Lost River for flood control. In October 1994, the Army Corps of Engineers granted a 10-year Section 404 permit that authorizes DOE-ID to discharge dredged and fill material associated with the excavation of soil material in Spreading Area B at the INEL. The permit prohibits construction activity at sites eligible for listing on the National Register of Historic Places.

The Birch Creek Playa at TAN is currently being evaluated to delineate areas within the historic playa which may be Waters of the United States. The Army Corps of Engineers decided in August 1994 that the Birch Creek Playa does not require a Section 404 permit for construction work and other borrow and fill work. 
Spill Prevention Control and Countermeasure Plans. Evaluations were conducted in 1993 to determine which INEL facilities are required under 40 CFR 112 to have a Spill Prevention Control and Countermeasure Plan. Determinations were made as to which facilities required plans, and plans were prepared and updated for those facilities. Plans and determinations were documented in the INEL Spill Prevention Control and Countermeasure Plans and Exemptions, isued in September 1994. Facilities reviewed their status in July 1995 and made changes where necessary.

Oil Pollution Abatement. Evaluations were conducted to determine applicability of a proposed Oil Pollution Abatement rule revision published in the Federal Register (58 FR 8824, February 17, 1993). The proposed rule requires preparation and submittal of facility response plans for facilities determined to be "substantial harm" facilities. Based on the evaluations, it was concluded that there are none of these facilities at the INEL, and that the INEL, as a whole, is not a "substantial harm facility." A certification of no substantial harm was prepared during fiscal year 1994 and placed on file at the INEL. A re-evaluation conducted in 1995 reconfirmed that the INEL is not a substantial harm facility.

\section{National Pollutant Discharge Elimination System (NPDES) Point Source Discharge Permits}

All INEL facilities were inventoried for process point source discharges to Waters of the United States in 1992 and 1993. In October 1993, information obtained from Phase I of the INEL Liquid Effluent Inventory and from evaluations conducted as part of the INEL Storm Water Pollution Prevention Plan (SWPPP) for Industrial Activities was examined to identify any potential point source discharges. One was identified-pressure relief discharges from
ICPP production well pump stations to the Big Lost River. A permit application for the ICPP discharges was submitted to EPA Region 10 in 1992, but EPA concluded that the pollutant discharges were minor and decided not to issue a permit at that time due to higher permitting priorities. ICPP is required to comply with Idaho Water Quality Standards.

\section{Storm Water Discharge Permits-Industrial} Activity. The INEL Storm Water Pollution Prevention Plan (SWPPP) for Industrial Activities for all applicable areas was implemented by October 1993. This plan provides for baseline and tailored controls and measures to prevent pollution of storm water. Annual evaluations are conducted by the SWPPP Team to determine compliance with the plan and the need for revision. Storm water monitoring is conducted by the LITCO Environmental Monitoring and Water Resources Group according to permit requirements and DOE Orders. The NOAA Air Resources Laboratory (ARL) provides identification and notification of storm events. Storm water pollution prevention training is provided for INEL personnel as the permit requires.

Storm Water Discharge Permit-Construction Activity. The INEL SWPPP for Construction Activities (DOE/ID-10425) was distributed in September 1993. This plan provides for measures and controls to prevent pollution of storm water. Worksheets are completed for construction projects and appended to the plan. Inspections of construction sites are performed in accordance with permit requirements. The NOAA/ARL provides identification and notification of storm events. Storm water monitoring is not a permit requirement. Storm water pollution prevention training is provided to INEL personnel and subcontractors as needed. 
Executive Order 11990_Protection of Wetlands

A plan to identify and field-verify regulated wetlands at the INEL was developed. Funding was allocated, and potential sites were evaluated in fiscal years 1994 and 1995. Sites delineated on the 1993 U.S. Fish and Wildlife Service INEL National Wetlands Inventory map were included in the process. The only areas identified as jurisdictional wetlands were in the area of the Big Lost River Sinks.

The U.S. Fish and Wildlife Service National Wetlands Inventory map is used as a source of information to identify potential wetlands or nonregulated sites with ecological, environmental, and future development significance. National Wetlands Inventory sites that are clearly not wetlands will be eliminated from INEL inventory maps with the concurrence of the U.S. Fish and Wildlife Service. Currently, there are no identified operations at the INEL that have a significant impact on jurisdictional wetlands. Present and future activities involving borrowing soil from Spreading Area B and Spreading Area A, respectively, may impact nonregulated wetlands to some extent.

\section{Executive Order 11988-Floodplain Management}

In the fall of 1993, DOE-ID obtained stereographic aerial photographic coverage of INEL site areas judged to lie within the 100-yr floodplains of the Big Lost River and Birch Creek as an initial step in the production of a map of INEL floodplains. Early in 1994, DOEID gave approval to the USGS to proceed with the remaining tasks in the floodplain mapping project. The aerial photographs have been used to produce detailed topographic maps (2-ft contours), an important prerequisite to mapping the floodplains. Personnel from the Boise
Office of the USGS began mapping tasks for the floodplain study in 1994. Maps of the 100yr floodplains of the Big Lost River and Birch Creek, and a report documenting the floodplain study, are expected to be finished in 1997. Presently, the preliminary modeling has been completed for Birch Creek and is under review. Work has been initiated on the Big Lost River model.

Although the floodplains of the Big Lost River and Birch Creek will be delineated by the present project, the project will not account for all areas on the INEL having a one-percent or greater chance of being flooded in any given year. Specifically, the study will not include areas that may be prone to flooding caused by runoff from local drainage basins. Runoff flooding studies will have to be conducted separately using the detailed topographic maps from the current project when available.

Two-ft contour maps have been completed for areas near INEL facilities, and the USGS is evaluating existing studies on the RWMC subbasin to determine if they are adequate for delineating the $100-y r$ to $500-y r$ floodplain. DOE-ID is seeking funding to conduct these studies on a sitewide basis, but these studies are currently planned on an as-needed basis only. In addition, the NOAAVARL is expanding and updating its computations of annual, extreme, and return period precipitation to further support these studies.

Floodplain Assessment-INEL. The assessment currently underway will determine the impacts of a 100-yr flood by the Big Lost River. It will also identify whether RWMC is in the Big Lost River 100-yr floodplain. Water flowing through a diversion channel near the RWMC goes into two spreading areas. These areas are currently being assessed to determine if past floodplain evaluations for potential RWMC drainage are adequate. 
From a regulatory perspective, there is a need to be able to identify whether RWMC is in a floodplain for the spreading areas as well. This could impact proposed activities such as the project to privatize alpha-contaminated lowlevel waste treatment and proposed activities related to wastes contaminated with polychlorinated biphenyl (PCB) materials currently stored at RWMC.

\section{State of Idaho Wastewater Land Application Permits (WLAPs)}

DOE-ID is obtaining State of Idaho WLAPs for existing and future land application facilities (i.e. percolation ponds and sewage treatment irrigation systems). Applications for WLAPs are being prepared for the Water Reactor Research Test Facility (WRRTF) Sewage and Process Ponds at TAN and the TRA Chemical Waste and Cold Waste Ponds. The ANL-W Industrial Waste Pond and Conveyance Ditches application was submitted by DOE-CH to the State of Idaho, and applications for the Technical Support Facility Disposal Pond at TAN and the NRF Industrial Waste Ditch have also been submitted to the State for review.

Final WLAPs were issued in September 1995 for the ICPP Percolation Ponds and the ICPP Sewage Treatment Plant Rapid Infiltration Trenches.

\section{Resource Conservation and Recovery Act (RCRA)}

This Act establishes regulatory standards for the generation, transportation, storage, treatment, and disposal of hazardous waste. The State of Idaho is authorized by EPA to regulate hazardous waste and the hazardous component of mixed waste at the INEL. (Mixed wastes contain both radioactive and hazardous materials.) Strictly radioactive wastes are regulated by the Atomic Energy Act as administered through DOE orders.
RCRA Inspection. Officials from the State of Idaho DEQ arrived at the INEL on September 12 to begin the annual RCRA inspection. The areas inspected during this visit were WERF, RWMC, and ANL-W. No Notice of Violation was received in 1995 for this inspection.

RCRA Notices of Violation. DOE's response to the State of Idaho's draft consent order to resolve the September 29, 1994, Notice of Violation was sent on March 13, 1995. A second draft consent order from the State was received in June 1995 to resolve alleged violations from this notice. By late July, the State of Idaho approved the RCRA Interim Status treatment for the ANL-W Sodium Component Maintenance Shop, a significant hurdle to be cleared prior to treatment of the Army Re-entry Vehicle Facility Site's sodium/potassium $(\mathrm{Na} / \mathrm{K})$ waste at ANL-W. The consent order for the September 1994 Notice of Violation was signed by the State on October 6, 1995.

In accordance with the consent order, the $\mathrm{Na} / \mathrm{K}$ was moved to $\mathrm{ANL}-\mathrm{W}$ and underwent treatment. Treatment was completed in early 1996. The last item for ensuring compliance in the consent order was maintaining the TAN storage overhead door in an open position to allow emergency equipment to enter for the movement of the $\mathrm{S} 1 \mathrm{G}$ sodium container in building TAN 647 to ANL-W for treatment.

On October 25, 1995, DOE-ID received a Notice of Violation for an inspection conducted in June 1994. This inspection covered ANL-W and the Hazardous Waste Storage Facility at CFA (both RCRA-permitted units). The Notice of Violation contained fines, all of which were assessed against ANL-W. The only violation associated with DOE-ID was for alleged failure to maintain appropriate documents at the storage unit. LITCO corrected that violation, and a settlement conference was held with Idaho DEQ in November 1995. The consent order for this notice was signed in May 1996. 
RCRA Closure Plans. The State of Idaho approved RCRA closure plans for (1) the ICPP Percolation Ponds \#1 and \#2 in November 1995, (2) the TRA 610 Lead Storage Unit in October 1995, and (3) the LOFT Chromate Water Storage Unit (TAN 726) with its associated Treatment Unit (TAN 726A) in December 1995.

RCRA Permitting Accomplishments. The internal comment period regarding the Research Development and Demonstration application for the Plasma Hearth Process began in 1995 and is still ongoing. The application was scheduled to be submitted to the State in June 1995. However, due to funding restrictions, the permitting process is on hold pending further review.

Revised RCRA Part B Application for the storage modules and the Intermediate-Level Transuranic Storage Facility were submitted to the State by March 13, 1995 . The INEL received the final RCRA Hazardous Waste Partial Permit for container storage at the Intermediate-Level Transuranic Storage Facility, Pad 2 and the Waste Storage Facilities (Type I and Type II) in November 1995. In May 1995, DOE-ID received a final partial hazardous waste permit from the State for the Hazardous Chemical Waste Handling and Neutralization Facility at ICPP.

Discussions with the State resulted in a new schedule for submission of the WERF Part B Permit application. The State agreed to the WERF incinerator trial burn plan in December 1995 and the Part B Permit application in February 1996.

RCRA Reports. As required by the State of Idaho, DOE-ID submitted the Idaho Hazardous Waste Generator Quarterly Reports for 1995. The reports contain information on waste generation, treatment, recycling, and disposal activities at INEL facilities for each quarter during 1995.

DOE-ID submitted the INEL 1995 Affirmative Procurement Report to EPA by December 1995, as required by Section 6002 of RCRA and Executive Order 12780. This report provides information on the INEL's procurement of products containing recovered, rather than new, materials.

The INEL RCRA permit for the Hazardous Waste Storage Facility at CFA and some areas at ANL-W requires submittal of an annual certification to Idaho DEQ that the INEL has a waste minimization program in place to reduce the volume and toxicity of hazardous waste. The certification was due to the State by March 1,1995 . Due to an oversight by DOE-ID and LITCO, however, that submittal did not occur until May 26, 1995. As soon as the oversight was discovered, DOE-ID contacted State officials to brief them on the issue. This report, required by DOE Order 5400.1, contains information on waste quantities generated and progress towards waste minimization goals at the INEL. In the future, the submittal date for this report will be July 1 to coincide with the development of the annual Waste Minimization Plan.

The Annual Report on Treatability Studies for Calendar Year 1995 as required by 40 CFR 261.4(f)(9) was submitted for the INEL in March 1996. Treatability Studies as defined by the Code of Federal Regulations are those in which a hazardous waste is subjected to a treatment process to determine: (1) whether the waste is amenable to the treatment process, (2) what pretreatment (if any) is required, (3) the optimal process conditions needed to achieve the desired treatment, (4) the efficiency of a treatment process for a specific waste or wastes, or (5) the characteristics and volumes of residuals from a particular treatment process ${ }^{\mathrm{a}}$. Also

\footnotetext{
" 40 CFR 260.10, “Hazardous Waste Management System,” 1995.
} 
included in this definition for the purpose of the 40 CFR 261.4 (e) and (f) exemptions are liner compatibility, corrosion, other material compatibility studies, and toxicological and health effects studies. A "treatability study" is not a means to commercially treat or dispose of hazardous waste.

RCRA Firing Range Issue. The Indoor Live Fire Range, used by the INEL security forces, was placed under restricted use by the LITCO Regulatory Affairs Group because of apparent inappropriate hazardous waste management activities. Previously, LITCO Safeguards and Security had obtained a report from an independent environmental consultant indicating that the firing range qualified for an exemption from hazardous waste regulations. However, the exemption was intended for outdoor firing ranges where spent lead would not be removed from the unit after it was used for its intended purpose. During operation of the indoor range, waste was generated, treated, and a small quantity was stored in a sump.

After LITCO determined the waste was hazardous, they requested clarification from the Idaho DEQ regarding how the facility should be operated. The DEQ stated that a Generator Treatment Plan was required for the facility's lead treatment unit, the treatment unit needed adequate secondary containment, and the residual waste in the sump needed to be removed within 24 hours.

RCRA Characterizations. On April 19, 1996, the facility manager for the Test Reactor Area made the required notifications for a substance release report for an inadvertent release in June 1995 from the TRA tank known as the "Brine Pit" to the TRA Chemical Leaching Pond.

As part of routine operations, corrosive regenerant effluent from the TRA demineralizer operation is regularly neutralized in the Brine
Pit and discharged to the Chemical Leaching Pond in full compliance with all applicable regulations. Between May 22 and June 22, 1995, a non-routine activity occurred at TRA when a project to flush residues from four storage tanks was begun. A regularly scheduled sample of the Brine Pit was collected June 14, 1995, and submitted for analysis. The sample was tested and failed the Toxicity Characteristic Leaching Procedure for mercury, but the report failed to note that a value had exceeded a regulatory limit. The regulatory limit in wastewater for mercury is $0.2 \mathrm{ppm}$, but the analysis of the sample showed a concentration of $0.29 \mathrm{ppm}$. This situation was discovered and eventually confirmed as accurate in April 1996. Release notifications were made as required.

Investigation of records confirmed that during normal operation of the demineralizer system, the mercury concentration in effluent is regularly between 0.01 to $0.1 \mathrm{ppb}(0.00001$ to $0.0001 \mathrm{ppm}$ ). Therefore, the only source that could account for the mercury contamination of the wastewater was the neutralization and flushing of the acid and caustic storage tanks in May and June 1995.

In order to calculate the estimated weight and volume of mercury discharged to the Leaching Pond during this period, assumptions were made related to the average concentration of mercury in the batches of wastewater discharged to the pond. Using an average concentration of $0.3 \mathrm{ppm}$, the total weight of mercury released would have been about $390 \mathrm{~g}$ $(0.9 \mathrm{lb})$. The total volume of mercury released would have been about $30 \mathrm{~mL}$ ( $1 \mathrm{fl} \mathrm{oz}$ ).

LITCO personnel performed a CERCLA evaluation with the calculated release information, and they concluded that the amount of the mercury inadvertently released to the Chemical Leaching Pond from May 22 to July 6,1995 , was negligible when compared to the amount of mercury contamination already present in the pond's sediments. 
Chapter 2: Environmental Compliance Summary

\section{Federal Facility Compliance Act}

This Act, which amends RCRA, requires the preparation of site treatment plans for the treatment of mixed wastes at DOE facilities which store or generate these wastes. Mixed waste contains both hazardous and radioactive components. The INEL Proposed Site Treatment Plan was submitted to the State of Idaho and EPA in March 1995. After a public review and comment period, a final version of the INEL Site Treatment Plan was agreed upon that formed the basis for State of Idaho and DOE-ID consent order negotiations for mixed waste treatment at the INEL. The Federal Facility Compliance Act Consent Order and Site Treatment Plan was finalized and signed by the State of Idaho on November 1, 1995. See Section 3.2 for more information.

\section{National Environmental Policy Act (NEPA)}

DOE-HQ requested input on a revision of DOE's NEPA Order 451.1, and the new Order was approved September 11, 1995.

Federal regulations require NEPA documentation showing that federal agencies have considered the environmental impacts of, and public comments on, proposed actions. This information must then be included in federal decision making. NEPA documentation can include a Categorical Exclusion, an Environmental Assessment (EA) or an Environmental Impact Statement (EIS).

Categorical Exclusions. A Categorical Exclusion is a category of actions that do not individually or collectively have a significant effect on the human environment, and do not require either an EA or EIS as followup. Due to a strategy of preparing generic or umbrella Categorical Exclusions, the number at the INEL dropped from 524 in 1992 to 319 in 1994 to 144 in 1995.
In August 1995, DOE-HQ determined that DOE organizations are no longer required to document categorical exclusions. The memo further stated that DOE officials may use any means they deem appropriate to obtain the information needed for categorical exclusion determinations. Each proposed action must still be reviewed in order to determine if it is categorically excluded or whether an EA or EIS is required. There will be no need to significantly modify the categorical exclusion process at the INEL except as follows: the DOE-ID Manager is no longer required to approve categorical exclusions, and there is no longer any need for a separate determination page. Environmental checklists will still be required, and a categorical exclusion will be considered completed when the DOE program/project representative and the NEPA Compliance Officer have initialed the checklist.

Environmental Impact Statements (EISs). The DOE Programmatic Spent Nuclear Fuel Management and INEL Environmental Restoration and Waste Management Environmental Impact Statement (hereafter referred to in this report as the INEL EIS) was released on April 21, 1995. The Record of Decision was issued May 30, 1995 and was published in the Federal Register. The Record of Decision selected an alternative composed of more than 40 actions at the INEL, some of which were subsequently tied up in litigation after the State of Idaho sued the Department of Energy, claiming that the INEL EIS was defective. This litigation was settled October 16, 1995 with an agreement between DOE, the Department of the Navy and the State of Idaho. The federal District Court entered a Court Order that incorporated as requirements all of the terms and conditions of the parties' settlement agreement, including a reduction in the number of spent nuclear fuel shipments coming to the State of Idaho. Subsequently, DOE decided the EIS Record of 
Decision would have to be amended to reflect this reduction. The draft Amended Record of Decision was signed by the Secretary of Energy in February 1996. Some projects described in the Court Order may require further project definition or NEPA evaluation in future years.

Environmental Assessments (EAs). Two EAs were completed and Findings of No Significant Impact were issued during 1995 for DOE-ID operations. These were for the Waste Characterization Facility in March 1995, and replacement of the Health Physics Instrumentation Laboratory in May 1995. These EAs were prepared in accordance with the 1994 Secretarial Policy on NEPA, which required that all EAs be submitted to the public for review and comment.

A third 1995 EA for the TAN Pool Stabilization Project underwent public review and comment during February 20 to March 21, 1995. The draft Finding of No Significant Impact and the EA were revised to incorporate public comments and were released for a second 30-day public review period from May 10 through June 9, 1995. The document was revised and the Finding of No Significant Impact was signed May 6, 1996.

During late 1995 and early 1996, ANL-W prepared an Environmental Assessment for operation of the ANL-W Fuel Conditioning Facility. The draft EA, Electrometallurgical Treatment Research and Demonstration Project in the Fuel Conditioning Facility at Argonne National Laboratory-West, was published in the Federal Registera. The Federal Register item discussed the availability of the draft and gave notice of public meetings. The original public comment period was February 5 through March 22, 1996. The comment period was extended,

\footnotetext{
" Federal Register, Volume 61, No. 23, Reference No. 02029602, February 2, 1996.
}

and ANL-W personnel are currently awaiting additional comments.

NEPA Planning Summary. In January 1996, DOE-ID released its annual NEPA Planning Summary, which describes proposed projects expected to be analyzed in either an EA or EIS. For either type of study, the public must be notified of comment and involvement opportunities. The 1996 summary lists the Advance Mixed Waste Treatment facility as a proposed project, but delays a decision on the appropriate environmental study until DOE reviews specific process data. The project planned is to be a privately-owned facility designed to treat alphacontaminated mixed low-level and transuranic wastes for final disposal. A request for proposals was issued in January, and DOE plans to award a contract by September 30, 1996. The treatment facility will fulfill one of DOE's commitments to the State as part of the spent nuclear fuel agreement signed with the Idaho Governor in October 1995.

The NEPA Planning Summary also provides brief descriptions of proposed projects that the department expects will require EAs: the Electrometallurgical Treatment Research and Demonstration Project at ANL-W; the Plasma Hearth Process Project; and the City of Boise Geothermal Project-Phase III. Also included are descriptions of the status of three projects for which NEPA reviews are now underway: the TAN Spent Fuel Pool Stabilization Project; the INEL Silt and Clay Borrow Source Sites; and the Waste Calcining Facility Decontamination and Decommissioning.

\section{Safe Drinking Water Act}

The Safe Drinking Water Act establishes primary standards for drinking water delivered by a system that supplies drinking water to 15 or more connections or 25 individuals for at least 60 days per year. The INEL drinking 
water supplies meet those criteria and are classified as nontransient noncommunity or transient noncommunity systems because persons who use the water do so four or five days per week but do not live at the Site. In October 1993, the State of Idaho instituted the assessment of fees for all public water systems, and the INEL pays a fee to operate 12 active public water systems.

All INEL facilities performed the recommended sampling of drinking water for volatile organic chemicals and synthetic organic chemicals during 1993 in order to be eligible to replace annual sampling with a triennial sampling period. Waivers were sought from the State of Idaho for the following: (1) dioxin sampling, because the chemical is not used at the INEL, (2) asbestos sampling based on previous analytical data showing the water has no asbestos contamination, and (3) sampling for synthetic organic compounds and volatile organic compounds. The Idaho DEQ granted these waivers.

The bacteriological program for drinking water at the INEL involves monthly testing for coliform bacteria. Further information on the results of this testing in 1995 may be found in Section 5.2, "Bacteriological Monitoring." Monitoring program results for radiological and nonradiological contaminants are described in Section 5.2, "Radiological Monitoring" and "Chemical Monitoring."

Occasional contamination of the Test Area North (TAN) drinking water distribution system with coliform bacteria was found during 1993 and 1994. There are four deep wells used for drinking water at TAN. In 1995, the TAN Chlorination Project completed installation of a government-furnished chlorine unit at TSF. Installation of the two remaining units will be completed in 1996.

Bacteriological contamination was found in the drinking water supply at TRA during 1995. A plan to install a permanent disinfectant system for the TRA water supply was submitted to the DEQ. The State granted permission to test a mixed oxidant system developed in Los Alamos, New Mexico. Following successful testing, work on certification and approval of the system by all necessary agencies can begin. The system was installed in early 1996 and testing is underway.

A new potable water well was drilled in 1993 at ICPP, but had continuing construction problems that limited its use during 1994. The well was fully operational during 1995 . The potable water storage tank upgrade project began in March 1995, and the new tank was on line and fully operational by the end of the summer.

\section{Toxic Substances Control Act}

This statute, which is administered by EPA, requires testing and regulation of chemical substances that enter the environment. The Toxic Substances Control Act supplements sections of the Clean Air Act, the Clean Water Act, and the Occupational Safety and Health Act. Compliance with the Act at the INEL is primarily directed toward management of polychlorinated biphenyls (PCBs).

\section{Storage of PCB-Contaminated Materials.}

DOE-ID continues to store radioactively contaminated PCBs at the INEL. Negotiations between DOE-HQ and EPA-HQ have resulted in a complex-wide agreement, expected to be signed in 1996, for storage longer than one year. DOE-ID is in the process of developing with EPA Region 10 an agreement for issues other than one-year storage of these materials. A package with a draft agreement and background information will be sent to EPA Region 10. Negotiation issues include characterization, inspections, and labeling.

Missed EPA Storage Deadlines. In March 1994, a concrete slab contaminated with PCBs 
was removed from a facility at TRA and placed into wooden boxes for ultimate disposal at a commercial licensed disposal facility. However, the packaging process was stopped when the INEL contractor discovered that all 11 wooden boxes were contaminated with radioactivity from previous use. The $5,000 \mathrm{~kg}(11,000 \mathrm{lb})$ of material could not be shipped to the disposal facility due to a waste shipping moratorium on items that were radioactively contaminated. EPA was notified that the INEL had exceeded the one-year storage requirement for PCB materials. The matter was resolved, and the PCB-contaminated material was shipped to the ChemWaste management facility in Arlington, Oregon during March 1995.

In November 1995, a letter of selfdisclosure was sent to EPA Region 10 that $0.6 \mathrm{~kg}(1.4 \mathrm{lb})$ of PCB waste that had been stored at the ICPP since December 1992 was in violation of the Toxic Substance Control Act one-year storage limit. The PCB waste was shipped to a disposal facility on November 14 , 1995.

PCB Treatability Study. During 1994, DOEID submitted a permit application for a gamma degradation treatability study to determine if PCBs can be destroyed by high-energy gamma radiation. Tests using the TRA fuel cells as the gamma radiation source successfully reduced the concentration of PCB congeners (similar compounds) in hydraulic oil by an order of magnitude-from $5000 \mathrm{ppm}$ to $556 \mathrm{ppm}$. The 1994 study results were promising - the treatment destroyed PCBs, did not generate any additional waste, and was relatively inexpensive when a source of gamma radiation was available. September 15, 1995, EPA issued the TSCA permit for the PCB Gamma Radiolysis Treatment Study. The first set of PCB samples was irradiated at the Advanced Test Reactor at TRA. The samples will be analyzed at CFA 615 and at an offsite laboratory. Preliminary results are promising, but final analytical results are not expected until 1996.

\section{Federal Insecticide, Fungicide, and Rodenticide Act}

This Act governs the registration and use of pesticides (i.e. fungicides, herbicides, insecticides, and rodenticides). The INEL complies with the Act's requirements pertaining to the storage and application of pesticides. There were no major activities or issues at the INEL with respect to this statute during the first 11 months of 1995. In December 1995, there may have been an incorrect application of the pesticide, diuron. A spill report was issued, and an investigation of the incident is underway.

\section{National Historic Preservation Act}

Preservation of historic properties on lands managed by DOE is mandated under Section 106 of the National Historic Preservation Act. The Act requires that when any federal undertaking will have an adverse effect on an historic property $^{a}$, the cognizant federal agency must enter into an agreement with the State Historical Preservation Officer (SHPO) for the purpose of mitigating those adverse effects.

During 1994, a Memorandum of Agreement was signed with the SHPO allowing the decontamination and dismantlement of historically significant buildings at the Auxiliary Reactor Area (ARA) I, II, and III facilities. Another Memorandum of Agreement relative to the decontamination and dismantlement of Building CF-640 at CFA was signed in 1995. Addressing each individual decontamination and decommissioning project with its own

\footnotetext{
a As defined in the Act, "Historic property means any prehistoric or historic district, site, building, structure, or object included in, or eligible for inclusion in, the National Register. This term includes, for the purposes of these regulations, artifacts, records, and remains that are related to and located within such properties."
} 
Memorandum of Agreement is costly and timeconsuming, so DOE-ID and LITCO personnel coordinated efforts to produce a draft of an INEL Historic Preservation Programmatic Agreement to address the historic preservation procedures in a consistent and efficient manner across the INEL.

The terms of this draft Agreement are the subject of ongoing negotiations between DOEID and the Idaho SHPO, and a finalized agreement is expected to be signed by the parties before the end of fiscal year 1996. The latest draft agreement was based on a new approach that evolved from a meeting between DOE-ID and the Idaho SHPO. This approach is more consistent with the SHPO needs than previous attempts, yet still allows DOE-ID to be proactive and cost-effective in their approach.

On May 26, 1995, the Idaho Department of Water Resources granted an emergency Stream Channel Alteration Permit to protect an archeological site immediately downstream from the INEL Diversion Dam on the Big Lost River. The emergency waiver allowed LITCO to begin work in the channel before spring runoff, moving the main channel toward the center of the river and protecting the archeological site by using a geotextile liner covered with river gravel.

All historic and prehistoric artifacts that were recovered from the INEL were sent to the Idaho Museum of Natural History in Pocatello. A curation agreement stipulating the procedures and policies for curation of these artifacts was signed by the Museum and the Archeological Society of Idaho.

\section{Native American Grave Protection and Repatriation Act}

The INEL is located on the aboriginal territory of the Shoshone people, and the Shoshone-Bannock Tribes are major stakeholders in INEL activities. They are especially concerned with how the remains of their ancestors and culture are treated by DOE-ID and its contractors. The Native American Graves Protection and Repatriation Act provides for the protection of Native American remains and the repatriation of human remains and associated burial objects. (Repatriation refers to the formal return of human remains and cultural objects to the culturally affiliated tribes to whom they belong.)

Human remains discovered in a trenching operation at PBF in the spring of 1994 were successfully repatriated during 1995 . In a very complicated cooperative effort between DOE, the SHPO, and the Shoshone-Bannock Tribes, the remains were officially returned to the Tribes according to the terms of the Native American Graves Protection and Repatriation Act. Because this effort was so successful, the SHPO has suggested working with the DOE-ID Cultural Resource Management Team to develop protocols based on this example to assist in future repatriations in the state.

\section{Endangered Species Act}

Various federal statutes, such as Executive Orders and the Endangered Species Act, govern the protection of ecological and biological resources at the INEL. Federal agencies are required to monitor threatened and endangered species on their lands and to devise a management plan for each. It is also as important to study candidate and sensitive species to aid in the decision-making process related to whether or not to list the species, thereby impacting land-use issues. Several species that live on the INEL are currently on various state and federal sensitive lists or have been declared candidates for federal listing.

The Environmental Science and Research Foundation performs ecological research, NEPA field evaluations of proposed project sites on the INEL that include assessment of the 
impacts on threatened and endangered species, and participates in annual surveys to determine the status of these species on the INEL. The Foundation contacts the U.S. Fish and Wildlife Service semiannually to update the INEL Threatened and Endangered Species List, which includes candidate and sensitive species (or species of concern).

The September 1995 listing shows several changes from the previous year. The bald eagle was no longer listed as endangered, but as a threatened species. The gray wolf was added to the list as an endangered species, but was further classified as an experimental, nonessential population, due to the reintroduction of Canadian wolves into Idaho wilderness areas and Yellowstone National Park. Added to the list, as Category 2 candidate species were a longlegged myotis (bat) and the loggerhead shrike (bird). The September Category 2 list also includes the ferruginous hawk, Western burrowing owl, pygmy rabbit, northern sagebrush lizards, and three other species of myotis.

In February 1996, the U.S. Fish and Wildlife Service redefined "candidate species" to include only those species for which sufficient evidence exists to support listing as Threatened or Endangered (former Category 1 candidates). The list of Category 2 candidate species has been discontinued. Although this action would appear to imply that Category 2 species are no longer of regulatory concern, the U.S. Fish and Wildlife Service plans to work with other federal agencies, states and private organizations to continue to identify species that warrant listing. Therefore, species of concern, species at risk, or any similarly designated species will be accorded the same emphasis and consideration as the former Category 2 species for NEPA evaluations and land use planning activities.

Several species of birds of prey (raptors) associated with the Threatened and Endangered Species List seen at the INEL include: the bald eagle, peregrine falcon, ferruginous hawk and burrowing owl. In January 1995, the Foundation conducted the National Wildlife Federation bald eagle count for the state zone that includes the INEL. On the INEL, these annual surveys are used to identify seasonal and geographic use of the Site by all raptors. The January 1995 survey, counted one bald eagle, seven golden eagles, two prairie falcons, 102 rough-legged hawks, 16 ravens, and one northern shrike. Only the bald eagle is listed as a threatened species. The loggerhead shrike, a former Category 2 species, is usually seen on the INEL during the Breeding Bird surveys done in the summer season. In 1995, 14 of these birds were seen.

During the summer of 1995 , INEL caves were surveyed for bats. Information related to the survey has not yet been published. Readers interested in more details on ecological research at the INEL may refer to a November 1994 listing of publications that have resulted from research conducted by the Foundation, the former DOE-ID Radioecology and Ecology Program, and university affiliates. The report ${ }^{\mathrm{a}}$ lists 332 publications resulting from research conducted by these groups from 1974 through 1994.

\subsection{OTHER MAJOR ENVIRONMENTAL ISSUES AND ACTIVITIES}

\section{Litigation Issues}

Fort St. Vrain Litigation. On December 22, 1993, the U.S. District Court issued its order approving the stipulation previously agreed to by the State of Idaho, the Secretary of the Navy,

\footnotetext{
a. C. Morris, Radioecology and Ecology Publications of the Idaho National Engineering Laboratory: 1974-1994, Environmental Science and Research Foundation, ESRF-003, November 1994.
} 
and the Secretary of Energy. The amended Court Order was entered by the Court after the Ninth Circuit Court of Appeals held that the trial court had abused its discretion by modifying the terms of the stipulation in an earlier order. The amended order required DOE-ID to renegotiate the administrative Notice of Noncompliance Consent Order with the State of Idaho signed in March 1994.

The latest order allowed a limited number of shipments of spent fuel to enter the INEL pending completion of the INEL-EIS. In addition, the order set accelerated milestones for the preparation of the INEL-EIS; transfer of spent fuel from ICPP-603 to ICPP-666; and treatment, storage and disposal of high-level radioactive wastes. All 1994 Court-ordered milestones were met before or on scheduled dates in 1995.

A claim was filed against DOE by the Public Service Company of Colorado alleging breach of contract on the part of DOE. The claim sought $\$ 92$ million in compensatory damages for DOE's failure to receive and store spent fuel from the Fort St. Vrain reactor north of Denver, Colorado. In October 1995, DOE and the Public Service Company signed an Agreement In Principle to resolve the claim against DOE. This agreement called for a modification of the terms of the 1965 and 1980 contracts between the parties relating to the shipment of the spent nuclear fuel to the ICPP.

On February 9, 1996, DOE and the Public Service Company of Colorado signed a settlement that allows continued safe storage of spent nuclear fuel from the Fort St. Vrain power reactor near Platteville, Colorado, until a permanent repository becomes available.

The out-of-court settlement between DOE and the Public Service Company resolves the company's claims against DOE emanating from the 1965 contract. The Company claimed the contract obligated DOE to receive spent nuclear fuel from the Fort St. Vrain reactor for storage.
However, DOE was unable to fulfill the contract because of the legal challenges to spent nuclear fuel storage at the INEL described in the next section. The utility company subsequently constructed and now operates an NRClicensed fuel storage facility located adjacent to the former Fort St. Vrain power plant. In lieu of accepting the spent nuclear fuel for storage in Idaho, DOE will take immediate title to the spent fuel and will pay the Public Service Company $\$ 16$ million to settle the claim. Company personnel will continue to manage the fuel for DOE under its current storage license until the NRC license has been transferred to DOE. At that time, DOE will take title to the facility and the property and begin managing it.

The agreement also meets one of the requirements of the October 1995 spent nuclear fuel agreement between DOE, the Navy and the State of Idaho, discussed in the next section. Under the DOE/State agreement, spent nuclear fuel from Fort St. Vrain can only be shipped to the INEL if a permanent repository or interim storage facility located outside the state of Idaho has been opened and is accepting fuel from the INEL. In that case, spent nuclear fuel from Fort St. Vrain could be shipped to the INEL for the purpose of preparing it for disposal or storage out-of-state.

Spent Nuclear Fuel Management and INEL Environmental Restoration and Waste Management Program EIS Litigation. In April 1995 the Department issued its final EIS regarding two questions of environmental impacts: 1) national management of DOE's spent nuclear fuel, and 2) DOE-ID management of INEL environmental restoration and waste management programs. On May 30, 1995 the Department published the Record of Decision addressing these two questions. At the same time, the State of Idaho and Governor Batt filed a motion in federal court alleging that DOE had failed to address all of the environmental 
impacts to Idaho in the EIS. The Court continued the injunction prohibiting the INEL from any transportation, receipt, storage, or processing of spent fuel until the issue of thoroughness of the EIS could be resolved.

Settlement discussions between the State of Idaho, the Governor, DOE, and the Navy continued throughout the summer, and ultimately resulted in a settlement agreement on October 16, 1995. This settlement agreement significantly reduced the number of shipments of spent nuclear fuel that DOE had originally decided to send to Idaho and requires the Department to accelerate and expand cleanup efforts at the INEL over the next several years. The court incorporated the terms of the settlement agreement in a Consent Order.

In mid-August 1995, prior to the signing of the settlement agreement, the Snake River Alliance Education Fund, Inc. also sued DOE, alleging defects in the EIS similar to those defects alleged by the State of Idaho. The Judge did not join the cases because it was his impression that the settlement discussions between the parties in the first case were going well, and he did not want the addition of a new party to disturb those negotiations. Following the settlement agreement, the Court removed the order prohibiting spent fuel activities at the INEL. The Snake River Alliance Education Fund, Inc. decided to continue its lawsuit despite the settlement agreement, claiming that it should have been involved in the settlement negotiations. The Judge has not yet ruled on this issue.

Following removal of the spent fuel activity injunction, an initiative sponsored by the group Stop the Shipments has been added to the November 1996 Idaho ballot. This initiative seeks to rescind the settlement agreement for the prior State of Idaho lawsuit and require legislative and electorate approval of all such future agreements pertaining to nuclear waste.
Following signing of the settlement agreement, the Shoshone-Bannock Tribes temporarily stopped a shipment of spent nuclear fuel in route to the INEL. Rail shipments pass through the Fort Hall reservation, and the Tribes are involved with INEL matters as a stakeholder. The Tribes are currently involved in negotiating an agreement similar to that settling the State of Idaho lawsuit.

\section{Mountaineer Refinery CERCLA Litigation.} In January 1995, DOE-ID received word from the Department of Justice that an amended complaint was filed in this action naming the Department of Energy as a defendant. The lawsuit was filed by a committee of potentially responsible parties involved in the CERCLA cleanup of Mountaineer Refining Company in LaBarge, Wyoming. Potential liability of DOE for cleanup costs was based upon allegations that contaminated oil wastes were shipped from the INEL to the Mountaineer Refinery for the purpose of refining it into usable petroleum products. The case was compromised and settled in 1995. In the spring of 1996, the case was dismissed with prejudice by the Court, which means that it cannot be refiled.

Improper Sample Disposal by INEL Employees. An assessment performed by EG\&G Idaho, Inc., Peformance Oversight and Assessment group during 1994, and continued by LITCO after they assumed operations on October 1, 1994, resulted in some potentially serious findings related to sample disposal. In March 1995, the Inspector General became involved in the investigation. These sample problems were isolated in nature and did not go beyond the independent actions of the two employees involved. In July 1995, DOE-ID requested that LITCO management make a detailed evaluation of the sample monitoring activities of the LITCO employees involved. 
DOE-ID specifically asked if any RCRA or Environmental Restoration programmatic decisions made at the INEL during the past five years were suspect as a result of the two employees' actions.

LITCO issued a formal report "Review of Environmental Monitoring Sample Collection, MSL-36-95" in September 1995. The report concludes, in part, that the data associated with the drinking water and liquid effluent monitoring programs did not affect programmatic decisions, and the improper employee actions were generally related to a disregard of safety requirements and appropriate procedures in the management and disposal of sample residues. Correct techniques for collection and analysis of samples were followed. There is no indication that INEL worker or public health was ever at risk due to the actions of the employees.

In September and October 1995, a DOE-ID team conducted a formal review of the LITCO Environmental Monitoring and Water Resources Unit, for which the two employees worked, to see if effective management systems were in place. Based on DOE-ID and LITCO reviews, DOE-ID concluded that the Unit was generally sound and supportive of waste management and programmatic decisions-the problems in the Unit did not go beyond the independent actions of the two individuals. On February 13, 1996, both individuals were indicted by a grand jury on multiple felony and misdemeanor charges related to the sample disposal problems.

In summary, the problems were generally limited to sample disposal and safety procedure violations (not sample collection and analysis), and these personnel did not collect samples for projects affecting major programmatic decisions. LITCO continues to seek opportunities for improvement in this important area. Investigations and improvements are currently underway related to management of sample storage and procedures and practices for proper disposal of samples. Both DOE-ID and LITCO will continue to closely monitor important environmental matters, and they will identify and address environmental program deficiencies as they occur.

\section{Ground-Water Monitoring Program Activities}

The INEL Ground-Water Monitoring Plan, written in accordance with DOE Order 5400.1, was completed in June 1993 with technical input from LITCO, USGS, and DOE-ID. The plan establishes the framework for ensuring compliance with all regulatory and DOE standards that require ground-water monitoring. The plan documents the INEL's regional and facility area-specific ground-water monitoring needs and documents the ground-water monitoring networks and sampling programs that must be developed to meet those needs.

Implementation of the plan was initiated in 1993 and continued in 1994. The ground-water monitoring network was completed at ARA, and work was initiated on the ground-water network at PBF. Evaluations were conducted in 1994 to further refine unit- or facility-specific ground-water monitoring needs. It is anticipated that the plan will be fully implemented by the year 2004. In addition to the 1995 compliance monitoring for WLAPs and other RCRA requirements, CERCLA monitoring was performed at INEL facilities.

In 1993, a physical survey of all wells at the INEL was completed by EG\&G, Idaho; and each wellhead was evaluated and, where necessary, upgraded. A "fitness" evaluation of all wells at the INEL was completed to determine whether the wells meet applicable state and federal well construction standards. Deficient wells are being prioritized and either upgraded or abandoned as funding becomes available. 


\section{Health Studies}

In December 1991, the Secretary of Energy and the Secretary of the Department of Health and Human Services signed a Memorandum of Understanding which transferred authority for the conduct and management of all epidemiological studies at DOE facilities to the Department of Health and Human Services. The dose reconstruction and worker epidemiology studies are discussed below. The Centers for Disease Control and Prevention (CDC) has established the INEL Health Effects Subcommittee, a public advisory group.

The first meeting of the Subcommittee was held in Idaho Falls December 12-13, 1995. This group will provide recommendations to the $\mathrm{CDC}$ and the Agency for Toxic Substances and Disease Registry regarding all three INEL health studies performed under the Memorandum of Understanding: the INEL Environmental Dose Reconstruction Project; the INEL worker epidemiology study; and health studies connected with CERCLA activities.

INEL Dose Reconstruction Study. The INEL Environmental Dose Reconstruction Project is being conducted by the National Center for Environmental Health of the CDC. In February 1995, DOE-ID received a copy of the Final Report on Phase 1 of the INEL Environmental Dose Reconstruction Project from Sanford Cohen \& Associates, completed in December 1994. Phase 1 identified and evaluated the documents and data at the INEL pertinent to a historical dose reconstruction. The products of Phase 1 included an 800-page final report and an electronic data base of about 75,000 pages. Phase 2 of the Project could not begin until the new Federal Advisory Committee, the INEL Health Effects Subcommittee, was established to recommend a scope of work.

\section{Epidemiological Study of Workers at the} INEL. The INEL Epidemiological Study of Workers, which will evaluate patterns of mortality in all workers at the INEL since 1949, is being conducted by the National Institute for Occupational Safety and Health (NIOSH) of the CDC.

The primary objective of this study is to assess poten al associations between exposures to ionizing 1.ddiation and/or other toxic elements in the INEL worksite and mortality in the work force. To meet this objective, NIOSH is conducting an all-cause epidemiological cohort mortality study and will evaluate the feasibility of a prospective cancer incidence study among INEL employees. Detailed exposure histories will be compiled for all workers using records from health physics and industrial hygiene at the INEL.

In 1995, scientists from NIOSH visited the INEL to continue the ongoing epidemiologic study of INEL workers.

\section{Human Radiation Experiments Study}

In August 1995, the Office of Human Radiation Experiments released a publication that describes 435 human radiation experiments conducted by the DOE and its predecessors ${ }^{2}$. The report includes summaries of two human radiation experiments performed at the INEL.

The first experiment was a series of Controlled Environmental Radioiodine Tests that were designed to develop models for predicting the movement of radioiodine through the human food chain. In some of the tests conducted between 1963 and 1966, volunteers drank milk or inhaled air containing radioiodine to obtain data on the transport of radioiodine to and through the body. The second experiment, conducted from 1965 to 1972 , involved the

\footnotetext{
a U.S. Department of Energy, Radiation Experiments Associated with the U. S. Department of Energy and Its Predecessors, DOE/EH-4091, July 1995.
} 
administration of radioactive material to volunteers for testing and calibrating whole body radiation counters.

The experiments performed at the INEL were neither classified nor performed in secret. Although signed consent forms were not found in all cases, a consent process, based on the principles of the Nuremburg Code, was used at the time of the experiments. As many as 46 volunteers participated in the experiments. The volunteers were employees of the U.S. Atomic Energy Commission. Radiation doses to the volunteers were less than one-tenth of the occupational radiation protection guidelines in effect at the time.

Copies of over 500 documents containing information related to human radiation experiments and experiments involving intentional releases of radioactivity to the environment at the INEL are available in the Idaho Operations Office Public Reading Room. Documents for all DOE facilities are available on the Internet ${ }^{\mathrm{a}}$. The INEL Human Radiation Experiments Team completed its formal activities in October 1995.

On October 3, 1995, the President accepted the final report from the Advisory Committee on Human Radiation Experiments. The report describes the committee's review and evaluation of human radiation experiments funded by the government, and the committee's findings and recommendations.

\section{Tiger Team Assessment Corrective Actions}

In June 1989, the Secretary of Energy announced an initiative to strengthen safety, environmental protection, and waste management activities at DOE production, research, and testing facilities. A Tiger Team assessment was conducted at the INEL during June and July of 1991 and the team's report listed a number of concerns and findings in four major

\footnotetext{
a Internet at http://www.ohre.doe.gov.
}

areas: 1) environmental, 2) management and operations, 3) occupational safety and health, and 4) overall safety and health. No findings were characterized as representing an imminent danger.

The DOE-ID and its contractors developed corrective action plans to address findings and concerns and have worked on closing activities as time and resources permit. Recently, more than 100 corrective action plans for findings and concerns at the ANL-W facility were transferred to DOE-CH for tracking and resolution. (Although it is located at the Site, the ANL-W facility is not a DOE-ID contractor.) During 1995, DOE-ID examined and re-evaluated Tiger Team action plans that remained open and closed more than 300 that ranked low on a risk-assessment scale. The INEL contractor consolidation and modifications to INEL facility missions that have occurred during the past two years have made many of the original corrective action plans no longer applicable to operations at the INEL.

\section{Environmental Occurrences}

The Clean Air Act of 1990 made ethylene glycol releases greater than $454 \mathrm{~g}(1 \mathrm{lb})$ reportable under CERCLA. In 1995, EPA raised the reportable quantity for ethylene glycol releases to $2,270 \mathrm{~kg}(5,000 \mathrm{lb})$. There were no reportable releases at the INEL in 1995.

At about 10:30 a.m. February 2, 1995, WERF personnel found water overflowing onto the low-level waste storage pad. The potential for the spread of contamination was recognized, and action was taken to avoid it. By 3:00 p.m., low-level waste containers had been moved from the flooded areas to dry areas on the pad. In addition, the water on the pads and in the seepage basins was sampled by environmental monitoring personnel to be certain it was not contaminated. Water was pumped out of the seepage basins, and WERF personnel ensured 
that the situation was stable prior to going home on February 2. A shift supervisor and minimum staff were at WERF on February 3 to monitor the situation and continue pumping the seepage basins.

Several small chemical spills occurred at TRA during 1995. The first occurred in late February when a commercial tandem tanker truck was discovered to be leaking small amounts of acid while enroute to deliver sulfuric acid to TRA. Only a few gallons were estimated to have leaked out on the INEL, with less than $4 \mathrm{~L}$ ( $1 \mathrm{gal})$ spilled at TRA. LITCO took swift and appropriate action to notify all parties and to locate and mitigate the spills at each of the INEL areas where they occurred. The total spill was below reporting requirements, although LITCO invited the Idaho State Police to view the tanker at TRA because of the potential for leakage of acid along the route from Salt Lake City where the truck originated. A small fitting on top of one of the tanks, used to pressurize it, had broken off. This allowed acid to spill while sloshing due to the truck's movement.

A second spill of approximately $250 \mathrm{~L}$ (66 gal) of sulfuric acid occurred in July 1995 during unloading operations at the TRA Demineralizer Building when acid overflowed from the storage tank vent. The spill was contained and neutralized. No personnel injuries occurred. Proper notifications were made to the EPA National Response Center and the State of Idaho.

On September 5, 1995, approximately $13,000 \mathrm{~L}$ (3,500 gal) of sodium hydroxide was inadvertently transferred from its storage tank to the Brine Pit at the TRA Demineralizer Plant during neutralization of regeneration effluents. Approximately $40 \mathrm{~L}$ (10 gal) leaked from the Brine Pit to the ground and was neutralized. This is less than the EPA reportable quantity.

On September 20, 1995 a hazardous substance spill occurred at ICPP during an asbestos removal activity. One of the workers accidently kicked a 4-L (1-gal) can of solvent set outside the CPP 630 building with the lid loosely in place. The can spilled about $950 \mathrm{~g}(2.1 \mathrm{lb})$ of Orange 150 [dipropylene-glycol-monomethyl ether], which has a reportable quantity of $454 \mathrm{~g}$ $(1.0 \mathrm{lb})$. The spill was contained and immediately cleaned up. No injuries or environmental impact occurred.

Another environmental incident occurred at the TRA Sewage Treatment Pond in early fall of 1995. Several dozen eared grebes, migratory diving birds, died at the newly constructed and partially filled TRA sewage lagoons. This occurred during leak-testing shortly after an aqueous polymer emulsion had been added to seal the bottom of the ponds. Project construction personnel discovered dead grebes during a routine project site inspection in September. They immediately reported the incident and information was relayed to DOE-ID and the appropriate natural resource trustees (e.g. Idaho Department of Fish and Game, U.S. Fish and Wildlife Service, and the Shoshone-Bannock Tribes).

Immediate actions were taken to develop and implement a hazing (or harrassing) program to prevent additional birds from landing on the ponds, and to collect and rehabilitate surviving distressed birds. Hazing was not fully effective, so Idaho DEQ granted permission to terminate the leak test and drain the ponds in midOctober.

A Special Agent for the U.S. Fish and Wildlife Service conducted an investigation because this die-off constituted a possible violation of the Migratory Bird Treaty Act. Site and construction personnel provided the agent with detailed information as well as pond water samples and frozen bird carcasses for laboratory analysis. No toxins were found in the carcasses. Deaths were from hypothermia, pneumonia, and other causes related to exposure, presumably due to a glue-like foreign 
Chapter 2: Environmental Compliance Summary

substance on the feathers that evidently reduced the natural insulation. Citations were subsequently issued to Soil Science International, the manufacturer of the soil sealant. The Special Agent complimented the Environmental Science and Research Foundation, Western Construction, LITCO, Soil Science International, and DOE-ID for their cooperation during the investigation and their prompt efforts to rehabilitate distressed birds and prevent additional exposures.

Sampling of effluents from the INEL Research Center and the Willow Creek Building located in Idaho Falls identified discharges that exceeded the Idaho Falls sewer code limits for various chemicals in January, February, April, and July of 1995. Analytical results from the February 1995 monitoring activities at the Willow Creek Building indicated that the silver concentration in the effluent was $0.67 \mathrm{mg} / \mathrm{L}$, which exceeded the City Sewer Code limit of $0.45 \mathrm{mg} / \mathrm{L}$. The City's Sewer Administration Office was notified and resampling was initiated as per the requirements of the Industrial Wastewater Acceptance Form. Analyses of the new samples showed the concentrations of silver were again within regulated limits.

A petroleum product release to the environment occurred on one occasion during 1995. On January 23, 1995, approximately 60 L (15 gal) of JP4 aviation fuel were spilled out of the vent of the aviation fuel underground storage tank at CFA 609. The driver for a fuel delivery vendor overfilled the tank causing the fuel spill. The spill was contained by the fire department Haz-Mat team, and DOE-ID and State of Idaho personnel were notified as appropriate.

\section{Environmental Oversight \& Monitoring Agreement}

A new Environmental Oversight and Monitoring Agreement was signed by DOE-ID,
DOE-Naval Reactors Idaho Branch Office, and Idaho Governor Batt in September 1995. The new agreement is in effect through September 2000.

The first five-year agreement, which was signed in 1989, produced completed research and development projects by the State of Idaho INEL Oversight and Monitoring Program staff entitled:

- The Straddle-Packer Determination of the Vertical Distribution of Hydraulic Properties in the Snake River Plain Aquifer at Well USGS-44, Idaho Chemical Processing Plant, Idaho National Engineering Laboratory

- A Comparative Evaluation of Conceptual Models for the Snake River Plain Aquifer at the Idaho Chemical Processing Plant, Idaho National Engineering Laboratory

- Estimation of Hydraulic Properties and Development of a Layered Conceptual Model for the Snake River Plain Aquifer at the Idaho National Engineering Laboratory

- Characterizing Aquifer Hydrogeology and

Anthropogenic Chemical Influences on Ground water Near the Idaho Chemical Processing Plant, Idaho National Engineering Laboratory.

The research activities for these projects have been completed, but not all theses have been submitted by the graduate students who did the research. Several projects were summarized and published in the Hydrogeology, Waste Disposal Science and Politics documentation of the Proceedings of the 30th Symposium on Engineering Geology and Geotechnical Engineering during 1994.

A Community Monitoring Station project for three stations is in the planning stage. Construction will begin in the fall of 1996 on the first station which will be located on the Idaho Falls Green Belt. The State Oversight Staff are also assisting the Shoshone-Bannock 
Tribe in constructing a Community Monitoring Station at Fort Hall.

\section{The Environmental Management Site} Specific Advisory Board-Idaho National Engineering Laboratory

The INEL Site Specific Advisory Board (SSAB) was formed in March 1994 after a lengthy design and selection process. Their charter is to provide input and recommendations on Environmental Management strategic decisions that impact future use, risk management, economic development, and budget prioritization activities. The SSAB also provides advice on any other Waste Management and Environmental Restoration projects which the Assistant Secretary, the Director of the Office of Public Accountability, or DOE field site manager assigns to the board for review and advice.

In March 1995, DOE-ID personnel participated on a Spent Nuclear Fuel Panel Discussion with the SSAB as a followup to a presentation in Boise earlier.

In July, the Environmental Restoration Program briefed the SSAB on Records of Decision for the SL-1/BORAX and CFA Landfills remediation projects. The briefing included the environmental risks at these sites, the proposed cleanup actions, and the corresponding costs and cost containment efforts. Capping is proposed for all of these sites.

At the August SSAB meetings in Idaho Falls, presentations were made on the INEL Site Treatment Plan, the Environmental Management Integration Plan, the Comprehensive Facilities Land Use Plan, and on systems engineering as applied to the Environmental Management integration strategy.

Presentations at the September 1995 meeting in Twin Falls included: the Advanced Mixed Waste Treatment Project, Pit 9, the Western Governors' Association Development of Innovative Technologies Program, and TAN. The SSAB sponsored a Transportation of Hazardous and Radioactive Materials Exposition with participants from LITCO, DOE-ID, Idaho Hazardous Materials Training Center, Idaho State Police, and the INEL Oversight Program. Approximately 100 members of the public attended including representatives from local offices of Representative Crapo and Senators Craig and Kempthorne.

\subsection{PERMITS}

Permits that have been granted to the INEL and those for which applications have been submitted are summarized in Table 2.2. The RCRA units operating in 1995 with Hazardous Waste Partial Permits included: the Hazardous Waste Storage Facility at CFA, the Radioactive Sodium Storage Facility at ANL-W, the Radioactive Scrap and Waste Facility at ANL-W, and the Hazardous Chemical Waste Handling and Neutralization Facility at ICPP. The final Hazardous Waste Partial Permit for container storage at the Intermediate-Level Transuranic Storage Facility, Pad 2, and the Waste Storage Facilities (Type I and Type II) at the RWMC became effective November 13, 1995.

Wastewater Land Application Permits have been granted for the CFA Sewage Treatment Plant, the ICPP Percolation Ponds, and the ICPP Sewage Treatment Plant. The INEL also received one blanket Well Construction Permit, covering 36 wells, from the Idaho Department of Water Resources (IDWR) in 1994.

The Idaho Department of Water Resources has granted Underground Injection Control permits allowing the continued operation of eight deep injection wells (defined as Class V under 40 CFR 144.6) at the INEL. These wells are used for draining excess surface water runoff to avoid facility flooding. 
TABLE 2.2

PERMIT SUMMARY FOR THE INEL (1995)

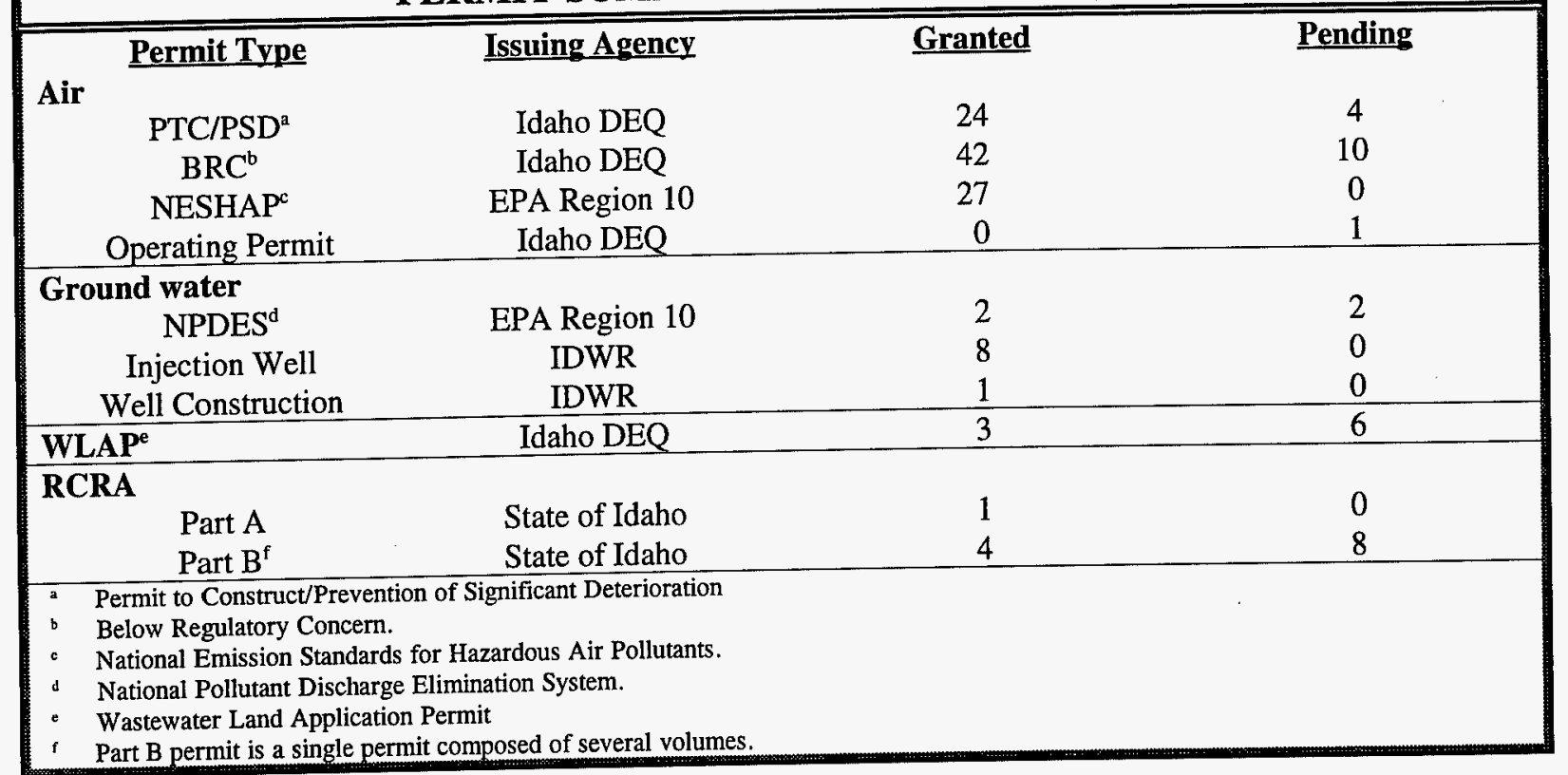




\section{Chapter 3. ENVIRONMENTAL PROGRAM INFORMATION}

\section{Chapter Summary}

This chapter describes major activities and milestones of two of the largest programs at the Idaho National Engineering Laboratory (INEL): the Environmental Restoration Program and the Waste Management Program. The Environmental Restoration Program section (Section 3.1) describes the activities within the 10 Waste Area Groups, ranging from limited field investigations termed Track 1 and Track 2 investigations, to major remedial investigation/feasibility studies, which take an average of two years to complete. The goal of the Waste Management Program (Section 3.2) is to manage wastes at the INEL in such a manner as to ensure that workers and the public are protected, and that there is no further impact to the environment. Major accomplishments for the program during 1995 are described.

Other programs at the AEL contain environmental components, and these are described in this chapter (Section 3.3). Public education programs and the publications designed to inform the public about the INEL activities are discussed in the same section.

Several groups at the INEL perform environmental monitoring of 1. various pathways by which nembers of the public could potentially be impacted by operations at the INEL (Section 3.4). During 1995, major environmental surveillanee activities at the $\mathrm{d}$./4 INEL were performed by the Environmental Science and Research Foundation, Lockheed Idaho Technologies Company (LITCO), the U.S. Geological Survey (USGS), the National Oceanic and Atmospheric Administration/Air Resources Laboratory (NOAA/ARL), and the State of Idaho. 


\section{ENVIRONMENTAL PROGRAM INFORMATION}

\subsection{ENVIRONMENTAL RESTORATION PROGRAM}

\section{General Information}

A common perception of environmental restoration investigative and remedial activities at DOE and other government sites is that all parts of the process are expensive and time-consuming. During recent years, however, streamlining environmental restoration activities at the INEL by DOE, EPA, and the State of Idaho has saved millions of dollars. This streamlining was possible due to the flexibility and management principles established under the Federal Facility Act/Consent Order such as:

- making cleanup decisions as soon as sufficient data are present

- using existing data whenever possible

- avoiding duplication of analyses and documentation and

- matching the level of investigation to the level of complexity of each release site.

An example of streamlining is seen in the use of limited field investigations (termed Track 1 or Track 2 investigations) instead of the more extensive remedial investigation/ feasibility studies (RI/FS) where appropriate. After each limited field investigation, a determination is made that no further action is necessary, that an interim action remediation is appropriate, or that further investigation in an RI/FS is needed. This approach greatly reduces the number of major investigations conducted.

The Federal Facility Act/Consent Order defines the 10 Waste Area Groups and lists specific areas of interest and/or concern in each.

The INEL Environmental Restoration Program has maintained significant progress in accomplishing its goals. As of November 1995 , a tally of environmental restoration activities at the INEL showed:

- 11 Records of Decision had been signed

- 11 removal actions had been completed

- 7 major investigations were in progress

- 346 of 455 preliminary investigations, and

- 40 of 115 enforceable milestones had been completed.

In all Waste Area Groups, the comprehensive remedial investigation/feasibility studies will begin in 1996 or are already under way. These studies represent the last environmental investigations for the individual Waste Area Groups at the INEL.

The comprehensive investigations, which take an average of two years to complete,

- determine the cumulative risks for an entire Waste Area Group by assessing the combined impact of all release sites within that Group

- review assumptions used in each previous investigation of "No Further Action" sites, Track 1 and 2, remedial investigation/ feasibility studies and interim actions

- identify data gaps and recommend actions such as field sampling or historical document research to resolve questions

- perform a feasibility study and recommend remedial alternatives for the entire Waste Area Group.

The general procedure for all comprehensive investigations begins with developing a Work Plan that outlines potential data gaps 
and release sites that may require more field sampling. Notices that an investigation is beginning are published through the INEL Reporter and a fact sheet $\mathrm{a}^{\mathrm{a}}$. At this time, the agencies (DOE, EPA, and the State of Idaho) are open to public scoping comments on what should be examined during a comprehensive investigation. Individual investigations will differ from one Waste Area Group to another, but each will determine what future cleanup actions may be needed at those areas. When the investigation is complete, DOE, EPA and the State will hold public comment meetings on the proposed cleanup alternative. Following the evaluation of public comments, the agencies sign a Record of Decision for the Waste Area Group documenting the final cleanup decision. The status of each Waste Area Group was given in the March/April 1996 edition of the INEL Reporter Supplement: Citizen's Guide. Major Environmental Restoration Program accomplishments for 1995 are described in the following sections.

\section{Waste Area Group 1-Test Area North}

\section{Test Area North (TAN) Ground-Water} Remediation. In 1993, cleanup activities were begun on the TAN Injection Well that was used from 1953 to 1972 to discharge liquid wastes into the fractured basalt of the Snake River Plain Aquifer. Those wastes included organic and inorganic compounds and low-level radioactive wastes that had been added to industrial and sanitary wastewaters. The resulting waste plume contaminated some of the drinking water wells that had been used by TAN workers. Since discovery of the contamination, drinking water has been treat-

\footnotetext{
- Internet at http://www.inel.gov then click button for "INEL and the Environment."
}

ed to meet drinking water standards, and untreated water is not accessible to workers or the general public.

An interim action was needed to remove the sources of contamination and to prevent further impact to the aquifer in the region. A subcontract was awarded for the design, construction, and operation of a GroundWater Treatment Facility, and the interim action began in March 1994. The objective was to pump and treat the TAN injection well water to remove the primary contaminant of concern, trichloroethylene. However, after the Treatment Facility had been operating for several months, the agencies were notified that the levels of contaminants were higher than previously known, other contaminants of potential concern were present and the Treatment Facility was not designed to treat some of these additional contaminants. The agencies temporarily suspended operation of the facility to consider expanding the preferred remedial alternative for the ground-water contamination by adding three new tasks: (1) sampling and analysis of the injection well water for better characterization; (2) testing to confirm removal of ${ }^{137} \mathrm{Cs}$ and other radionuclides; and (3) alternately pumping and emptying the injection well repeatedly to remove the buildup of material that had been injected into the well.

A separate remedial investigation/ feasibility study, addressing the organic contamination plume beyond the injection well was completed in 1994. The TAN ground-water final remedial action Record of Decision was officially approved by representatives of the EPA and State of Idaho in August 1995. The Ground-Water Treatment Facilities used in the earlier interim action were purchased from the subcontractor by DOE and have been operated to surge and stress the injection well since 
Chapter 3: Environmental Program Information

soon after the Record of Decision was signed. The area of highest contaminant concentrations immediately surrounding the injection well will be contained and the ground water treated to reduce contamination levels. The Decision also prescribes that new, innovative technologies will be evaluated to determine whether there is any benefit to using them rather than the traditional air stripping and ion exchange processes to treat the ground water.

\section{Test Area North Technical Support Facility}

Railroad Spur. Field work at the TAN Technical Support Facility mercury removal action site was completed in November 1994. The site consists of the rail bed and soil extending $1 \mathrm{~m}$ ( $3 \mathrm{ft}$ ) on each side of the tracks of a railroad spur adjacent to TAN-607. During the 1950s and 1960s, elemental mercury was used as radiation shielding in the Heat Transfer Reactor Experiment-III engine. Soil contamination apparently occurred as these engines were transported along the track. In a 1993 field screening survey, elevated levels of mercury vapors were found along two sections of the railroad track. About $90 \mathrm{~m}^{3}\left(120 \mathrm{yd}^{3}\right)$ of mercury-contaminated soil and gravel were removed from the site during 1994, and the site was backfilled with clean soil. The contaminated soil was processed through a mercury retort unit at the CFA during 1995 , and the recovered mercury will be recycled. Also as part of this removal action, mercurycontaminated railroad track was decontaminated and recycled, and 6-m (20-ft) wooden railroad ties were sent to the CFA Landfill Complex for disposal.

\section{Comprehensive Remedial Investigation/} Feasibility Study. This investigation began at the Waste Area Group 1 during 1995, and DOE-ID submitted the draft Final Work Plan to EPA and the State of Idaho on January 24, 1996. In addition to the 11 operable units and 94 potential release sites, V-tanks (i.e., tanks containing both hazardous and radioactive wastes) will also be evaluated during this final investigation. Activities planned for 1996 include collecting samples from the V-tanks and at a diesel spill site and beginning the comprehensive baseline risk assessment in the fall.

\section{Waste Area Group 2-Test Reactor Area}

Perched-Water System. The perched-water system under TRA is a zone of ground water that is "perched" on a relatively impermeable layer of clay $100 \mathrm{~m}(330 \mathrm{ft})$ above the Snake River Plain Aquifer. It was formed over time by seepage from the TRA wastewater disposal ponds. The INEL Project Office of the USGS has monitored the perched-water system in the TRA area for many years. LITCO personnel began compliance monitoring following the closure of the TRA Radioactive Waste Pond. DOE-ID, EPA, and the State will decide during 1996 on appropriate future monitoring. The agencies, with input from USGS experts, will use the monitoring data to determine whether contaminant concentrations are behaving as predicted in the perched water.

\section{Comprehensive Remedial Investigation/} Feasibility Study. Activities performed in 1995 related to the comprehensive investigation for Waste Area Group 2 included completing the Work Plan, and finalizing issues concerning the performance of the comprehensive baseline risk assessment and sampling. (Soil samples were collected from four sites at TRA, and analyses were completed during 1995.) Sampling data collected for the comprehensive investigation were included in 
the comprehensive baseline risk assessment that began in October 1995.

During May 1996, DOE plans to submit the baseline risk assessment to the EPA and the State. The remedial investigation/feasibility study should be finalized in late summer, and DOE plans to submit a draft Proposed Plan to EPA and the State in December.

\section{Waste Area Group 3-Idaho Chemical Processing Plant (ICPP)}

\section{Comprehensive Remedial Investigation/} Feasibility Study. The Waste Area Group 3 Work Plan was first submitted to EPA and the State of Idaho in March 1995 for their review and comment. Field work in support of the comprehensive investigation began in early May 1995. The Work Plan was finalized and sampling and analysis activities involving ground-water wells and soil-boring sites were completed. Ground-water modeling and the risk assessment were used to determine whether two perched-water zones at ICPP should be pumped and treated. That information will be included in the comprehensive baseline risk assessment, scheduled to be submitted to EPA and the State of Idaho in June 1996.

\section{Waste Area Group 4-Central Facilities Area (CFA)}

\section{Simulated Calcine/Mercury-Contaminated} Soil Removal Action. A removal action associated with a Track 2 investigation was begun during the summer of 1994 when simulated calcine material and soil contaminated with mercury and radioactive tracers were removed from a dry pond near building CFA-674. The pond was used in the 1950s and 1960s to dispose of materials from the Chemical Engineering Laboratory during the development of a nuclear waste calcining process.

About $260 \mathrm{~m}^{3}\left(340 \mathrm{yd}^{3}\right)$ of simulated calcine and mercury-contaminated soil were treated through a retort unit during 1995 . The unit uses a thermal process to recover mercury from the contaminated material. The mercury recovered from the CFA removal action will be sold commercially for recycling, and the treated soil from the process will be returned to the dry pond.

French Drain Removal Action. Five French drains (shallow surface drains) and associated contaminated soils were removed as part of a CFA removal action in 1995. Environmental Restoration Program personnel began removing the five drains in July 1995. Removal of the drains was followed by investigation for any residual contamination. The drains were used until about 1984 to dispose of wastewater from laboratory operations and from a craft shop. Solvents, acids, bases and metals were present, and some had varying concentrations of radionuclides. About $29 \mathrm{~m}^{3}$ $\left(38 \mathrm{yd}^{3}\right)$ of material contaminated with radioactivity was removed and sent to the RWMC for disposal.

Landfills I, II and III. The field work for the CFA Landfills Remedial Investigation/ Feasibility Study was completed in the summer of 1993, and the final report was issued in February 1995. An Update Fact Sheet published in April 1995 discussed results of the investigation and announced the public comment period for the proposed plan was to be held between April 26 and May 26, 1995. The Record of Decision, signed in October 1995, 
Chapter 3: Environmental Program Information

calls for a native soil cover to be placed on the landfills. The covers will prevent exposure of landfill personnel to the wastes and will minimize infiltration of water into the landfills, which could cause migration of contaminants to the aquifer. The Record of Decision also provides for institutional controls to restrict public and personnel access to the landfills and monitoring of ground water, infiltration, and the vadose zone.

Actual field work to cover the landfills has begun. Used as recently as 1984, the landfills accepted municipal-type and industrial wastes generated from INEL operations. Wastes disposed to the landfills included cafeteria garbage, trash sweepings, weeds, grass, asphalt, asbestos, scrap lumber, and metal. DOE-ID, EPA and the State agreed to take action to reduce any potential of ground-water contamination from the landfills and risks associated with exposure to the waste.

Although an assessment of the landfills did not clearly identify any unacceptable risks, there is some uncertainty as to the types and volumes of wastes disposed to the landfills. The agencies concluded that the uncertainty related to the presence of possible hazardous contaminants in the landfills constitutes an unacceptable risk and warrants remedial action.

Comprehensive Remedial Investigation/ Feasibility Study. The final investigation for the CFA will begin in 1996. DOE plans to hold scoping meetings with EPA and the State of Idaho as well as to prepare and finalize a Work Plan and Scope of Work. A total of 13 operable units and 50 potential release sites will be examined during this investigation.
Waste Area Group 5-Power Burst Facility/ Auxiliary Reactor Area (ARA)

Stationary Low-Power Reactor-1/Boiling Water Reactor Experiment-I. Although these two reactor burial sites are located in different Waste Area Groups, similarities led to combining them for the investigative and remedial processes.

The Stationary Low-Power Reactor-1 facility was a small nuclear power plant designed for the military to generate electric power and heat for remote installations. It accidentally achieved a critical reaction on January 3, 1961, resulting in a steam explosion that destroyed the reactor and killed the three operators on duty. To minimize radiation exposure to site workers and the public, a reactor burial ground was built for the contaminated debris near the original reactor site. Disposing of the material onsite was preferable to transporting the radioactive debris over $26 \mathrm{~km}(16 \mathrm{mi})$ of public highway to the RWMC.

The Boiling Water Reactor Experiment-I facility was a small reactor for testing boiling water reactor technology. It was intentionally destroyed in 1954 after completion of its mission. The destruction of the reactor contaminated about two acres of surrounding terrain. Much of the reactor debris was buried in place and the area was covered with about $15 \mathrm{~cm}$ (6 in) of gravel to reduce radioactivity levels.

The remedial investigation tasks for both sites included searching historical records, reviewing past sampling and radiological survey data, and performing computer modeling to estimate types and concentrations of radionuclides buried at the sites. Risk calculations 
were made and presented during a public comment period completed in May 1995.

The Record of Decision was signed in January 1996. The selected remedy for the two sites was to cap them with natural materials. The goal is to inhibit migration of the contaminants and to prevent direct exposure to ionizing radiation. Other major components of the selected remedy include recontouring and grading the surrounding terrain to direct surface water runoff away from the caps; inspecting and maintaining the caps; conducting periodic radiological surveys of the areas; restricting access; and restricting land use to industrial applications for at least 100 years following installation of the caps. Actual construction of the landfill caps is scheduled to begin in the summer of 1996.

Auxiliary Reactor Area. A Track 2 summary report of the ARA area was sent to the State of Idaho and EPA in July 1994. The report recommended that there be no further action at the ARA-IV Contaminated Leach Pit $\# 1$, and that a comprehensive remedial investigation/feasibility study of the ARA-III Radwaste Leach Pond be done. A letter of concurrence was received from the State of Idaho in early 1995.

\section{Power Burst Facility Corrosive Waste} Sump and Evaporation Pond Interim Action. From 1978 to 1985 , the PBF corrosive waste sump was used during neutralization of the reactor's secondary coolant water before discharge to the PBF evaporation pond. As a result, heavy metals and radionuclides contaminated the inside of the sump.

In late 1994, hazardous sludge was removed from the sump, dried, packaged and stored until a treatability study could be completed to determine what technique(s) were needed to stabilize the sludge to meet waste acceptance criteria for final disposal at the RWMC. During early February 1995, mixed waste from the cleanout of the PBF corrosive waste sump was transferred to the Mixed Waste Storage Facility at CFA to complete the interim remedial action. Efforts are underway in 1996 to finalize the strategy for permanent disposal of the waste.

The PBF evaporation pond sediments that were contaminated with chromium and radionuclides were removed from the pond bed in 1994, placed in closed containers, and shipped to RWMC. In June 1995, the pond liner was removed and sent to the CFA landfill for disposal. The berms which formed the walls of the pond were leveled. The area will be reseeded to complete restoration of the site.

\section{Comprehensive Remedial Investigation/} Feasibility Study. The final investigation for Waste Area Group 5 began in mid-February 1995. Activities planned for 1996 include site screening activities and preliminary agency scoping on the baseline risk assessment. Waste Area Group 5 has 13 operable units and 58 potential release sites.

\section{Waste Area Group 6-Boiling Water Reactor Experiment}

Boiling Water Reactor Experiment I. Remediation of this reactor burial site is discussed under Waste Area Group 5 with the SL-1 burial ground discussion.

Comprehensive Remedial Investigation/ Feasibility Study. The comprehensive investigation for Waste Area Group 6 is being conducted in combination with the Waste Area Group 10 Comprehensive Remedial Investigation/Feasibility Study. 
Waste Area Group 7-Radioactive Waste Management Complex

\section{Remedial Action of Organic Contamination} in the Vadose Zone. The Record of Decision signed by DOE, EPA and the State of Idaho agreeing to use the vapor vacuum extraction with treatment as the remediation technology for the vadose zone at RWMC became final on December 2, 1994. The vadose zone is the area between the land surface and the top of the water table. Organic vapors were released into this zone when buried drums containing volatile organic compounds, such as degreasers and solvents, deteriorated over time. The three agencies agreed to take action because small quantities of the contaminants had already reached the Snake River Plain Aquifer. The concentrations within the aquifer are below drinking water standards and there is no significant health risk to workers from drinking the water of the production well at the RWMC.

The full-scale extraction/treatment system was installed during 1995 and became operational January 11,1996 . It consists of three treatment units that extract vapors from five wells. The extracted vapors are then treated using a state-of-the-art process called "Recuperative Flameless Thermal Oxidation." When the vapors reach the optimum oxidation temperature inside the treatment units, the majority of organic compounds break down chemically to form carbon dioxide, hydrogen chloride and water. Extensive modeling of air emission impacts was performed to determine ambient and occupational air quality impacts from the project. Actual emission levels will be measured periodically to ensure compliance with Applicable or Relevant and Appropriate Requirements and to ensure safety of workers and the public.
Pit 9 Interim Action. During 1993, DOE, EPA and State of Idaho officials signed a Record of Decision for Pit 9 at the RWMC. Pit 9 is an inactive disposal pit covering about one acre. Most of the waste in the pit originated at the Rocky Flats Plant in Colorado and the INEL. The clean up contract for Pit 9 was awarded to Lockheed Environmental Systems and Technologies (LESAT) in October 1994.

This particular project provides DOE with a significant advantage; it demonstrates technologies that may be applicable to other DOE sites. The remediation at Pit 9 will allow field-testing of technologies for retrieving and treating low-level radioactive waste and transuranic mixed waste (waste that contains both radioactive and hazardous chemical components). The technologies, with little or no modification, may then be applied to similar wastes buried and stored at other DOE facilities around the country. Modular facilities successfully demonstrated at the INEL would eliminate the need for designing and constructing permanent remediation facilities at each DOE site.

The cleanup contractor, LESAT, proposed a three-stage process for Pit 9: physical separation, chemical treatment and stabilization. They plan to use remote retrieval technologies to safely remove soils and waste from Pit 9, separate radionuclides and hazardous chemical wastes from soils, destroy the organic materials, and transform the remaining waste into a glass-like material which exceeds waste disposal requirements.

In addition to the work taking place at the INEL's RWMC, other components of Pit 9 project are being assembled and tested at other locations: a plasma melter in Ukiah, California, a retrieval facility in Houston, Texas, a soil-wash component in Bellevue, Washington, a test-bed facility in Salt Lake City, Utah, a dig-face monitoring and assay 
system in Los Alamos, New Mexico, a shredder in Columbus, Ohio, and special boxhandling equipment in Houston, Texas.

Site preparation and grading for the Pit 9 treatment facility began in December 1994. The Pit 9 Remedial Design/Remedial Action Scope of Work update was finalized DOE, EPA, and the State of Idaho in January 1995.

On May 23, 1995, LITCO turned over control of the Pit 9 portion of the Subsurface Disposal Area at RWMC to the contractor, LESAT, and they were authorized to begin construction activities. Contractor personnel began sampling soil to characterize the Pit 9 overburden in July 1995. These soil samples, taken from about 90 different locations, were analyzed for organic compounds and radioactive isotopes to determine whether the soil is contaminated above background levels. Construction of the treatment facility at Pit 9 began in the fall of 1995 and will be completed in the summer of 1996. During the fall of 1996, the contractor plans to conduct a limited production test to process a small amount of simulated and actual Pit 9 waste. If the test is successful, LESAT will proceed with full-scale remediation. Cleanup of Pit 9 is scheduled to be completed in 1998 .

Pad A. Pad A at the RWMC received packaged mixed wastes from 1972 to 1978 primarily from the Rocky Flats Plant in Colorado. Hazardous wastes included evaporator salts, primarily sodium nitrate and potassium nitrate, while radioactive wastes included plutonium, americium and uranium. Pad A was used for disposal of $10,000 \mathrm{~m}^{3}$ $\left(13,000 \mathrm{yd}^{3}\right)$ of wastes.

The Record of Decision for Pad A was signed by DOE-ID, EPA, and the State in February 1994. The selected alternative involved placing plywood and/or polyethylene over many of the containers and covering them with a $0.9-\mathrm{m}$ (3-ft) soil layer. Recontouring of the pad cover was finished in late 1995.

The INEL has now entered into the postRecord of Decision period of maintenance and monitoring of the pad cover. As part of this activity, personnel will monitor soil, surface water, air and existing ground-water wells. Monitoring will continue for five years, then the data will be evaluated to verify the protectiveness of the remedial action. The monitoring information is being included in the Waste Area Group 7 comprehensive investigation.

\section{Comprehensive Remedial Investigation/}

Feasibility Study. The final investigation to evaluate Waste Area Group 7 in its entirety was initiated in 1995 to collect data and evaluate the cumulative impacts of the buried waste and the historical release from the Transuranic Storage Area. The Work Plan was finalized in March 1996. When approved, the Plan was submitted to the Administrative Record where it, along with other public information pertaining to the comprehensive investigation, is available to the public.

\section{Waste Area Group 8-Naval Reactors Facility}

Naval Reactors Facility Remediation. The DOE, EPA, and State of Idaho signed a Record of Decision for 10 sites at the NRF in 1994. Three of these sites were landfills which the agencies agreed should be capped with a native soil cover. The agencies agreed the other sites (the industrial waste ditch and six other landfills) required no further action.

Comprehensive Remedial Investigation/ Feasibility Study. The Work Plan for the Waste Area Group 8 comprehensive 
Chapter 3: Environmental Program Information

investigation was finalized in November 1995. When approved, the Plan was submitted to the Administrative Record where it, along with other public information pertaining to the comprehensive investigation, is available to the public.

\section{Waste Area Group 9-Argonne National Laboratory-West}

Radioactive Liquid Waste Transfer Line Best Management Practice. Personnel will remove and collect samples from $60 \mathrm{~m}(200$ $\mathrm{ft}$ ) of pipe from a lift station (sump) that leads to the ANL-W Leach Pit. The pipe will then be sent to RWMC for disposal. It is suspected that the pipe contains low levels of radioactive contamination.

\section{Comprehensive Remedial Investigation/} Feasibility Study. ANL-W began its comprehensive investigation for Waste Area Group 9 in June 1995. Preliminary data were collected in the Fall of 1994 for this investigation. The Scope of Work is final, and the Draft Work Plan was sent to EPA and the State of Idaho in March 1996 for review. The baseline and ecological risk assessments to evaluate the impacts to human health and the environment of 19 potential release sites at ANL-W will be completed in 1996. No contaminants that are attributable to ANL-W activities have been found in the Snake River Plain Aquifer.

\section{Waste Area Group 10-Miscellaneous Sites/Snake River Plain Aquifer}

Unexploded Ordnance Projects. Unexploded ordnance items on the INEL resulted from gunnery activities at the former Naval Proving Ground, which lies within the present INEL boundaries. Prior to 1949 , the Navy conducted aerial bombing practice, naval artillery testing, explosives storage bunker testing, and ordnance disposal on a large portion of what is now the INEL. The EPA, DOE and State of Idaho addressed the effects of past ordnance activities by planning an interim action, a removal action, a Track 2 investigation, and a project to test the use of bioremediation techniques to clean up soil contaminated by explosives at a facility used by NOAA/ARL.

The interim action project to locate and detonate unexploded ordnance items resulting from past activities in areas near CFA, ICPP and the central corridor of the INEL was completed in 1993. Soil contaminated as a result of past and recent detonations was removed for offsite incineration at an EPAapproved commercial facility.

The removal action to clean up unexploded ordnance at the Naval Ordnance Disposal Area (NODA) and at the Twin Buttes Bombing Range was begun during the 1994 field season. However, on July 29, 1995, LITCO halted all remediation activities on two hazardous pits in the NODA due to personnel safety concerns. Coincidentally, DOE-ID personnel from the Technical Development group were trying to schedule a demonstration of a remote excavation technology at the INEL as part of an ongoing research and development agreement with Tyndall Air Force Base. Personnel from both INEL groups worked together to use the remote excavation technology on the NODA pits. There was no cost to the Environmental Restoration Program during the demonstration, and it provided greater safety for the operations personnel. This crosssharing of technology and resources achieved objectives for both groups and avoided duplicative efforts that would have cost an estimated additional $\$ 250,000$ and significant schedule delays on the ordnance project. The NODA 
removal action was completed by October 1995.

The Track 2 investigation, which began in October 1995, addresses areas on the INEL where unexploded ordnance and soils contaminated with explosive residues are poorly defined by historical documentation. These potentially contaminated locations will be evaluated during the investigation, and the use of bioremediation technologies will be considered.

Bioremediation uses microorganisms to break down organic contaminants into less hazardous compounds, such as carbon dioxide and water. This conversion process, which normally occurs over time, is faster when oxygen and nutrients are added to the soil to stimulate bacterial activity. Bioremediation has been used successfully at Department of Defense sites to reduce concentrations of explosive agents in the soil.

\section{Radionuclide-Contaminated Soils Removal} Action. On May 4, 1995, DOE, EPA Region 10 , and the Idaho Department of Health and Welfare determined that seven of the Waste Area Group 10, radionuclide-contaminated soil sites were to be remediated through removal actions. The INEL removed, consolidated and contained approximately 7,600 $\mathrm{m}^{3}\left(10,000 \mathrm{yd}^{3}\right)$ of radionuclide-contaminated soils (that resulted from spills, storage, and windblown contamination) from these seven locations. Primary contaminants at the locations included ${ }^{137} \mathrm{Cs},{ }^{90} \mathrm{Sr}$ and ${ }^{152} \mathrm{Eu}$. The excavated soil was collected and transported by truck to TRA where it was stored within the 1957 cell of the old TRA Warm Waste Pond.

The actual soil removal began in late August 1995 and was complete in November 1995. Excavation at one of the seven loca- tions near TAN showed that contamination was widespread in several areas and could not be completely remediated through this soil removal action. Further assessment of that contamination is being conducted, and it may be appropriate to address this problem in the final TAN comprehensive remedial investigation/feasibility study. The excavated areas were recontoured and reseeded.

\section{Comprehensive Remedial Investigation/} Feasibility Study. The final investigation for Waste Area Group 10 will begin in August 1996. This investigation will address potential release sites in Waste Area Groups 6 and 10 and the Snake River Plain Aquifer. Sampling activities will be conducted in 1997 to provide information for the baseline risk assessment.

\section{Decontamination, Dismantlement, and Demolition Activities}

Decontamination, dismantlement, and demolition activities at the INEL are primarily concerned with the safe decontamination of existing structures that can be reused and the demolition and disposal of surplus facilities.

Surplus Facility Action Plan. An extensive facility usage review, which evaluated each facility's current condition, usage, and potential future, was conducted at the INEL. The first Surplus Facility Action Plan for the INEL was subsequently completed in September 1995 . The plan identifies all the surplus facilities at the INEL and the action needed to move them from their current deactivated status to reuse, or through decontamination and on to dismantlement and demolition, as needed. A total of 30 buildings at ICPP, CFA, TAN and in Idaho Falls were identified for 
closure and deactivation. Fourteen of these had been deactivated and secured in 1995 . Eight more are scheduled for 1996.

In order for deactivation of buildings at two INEL facilities (PBF and TRA) to occur, it was necessary to transfer ownership within DOE-HQ of the specific facilities from the Office of Nuclear Energy to the Office of Environmental Restoration and Waste Management. A Memorandum of Agreement was signed in September 1995 that made the ownership transfer of the Power Burst Facility assets and Test Reactor Area (TRA-660) Advance Reactivity Measurement Facility/ Coupled Fast Reactivity Measurement Facility and ancillary facilities.

Local Demolition Approval Authority. On August 4, 1995, DOE-ID received verbal approval from the General Services Administration (GSA) Region 10 for real property disposal authority. This gives DOEID the authority to dispose of "improvements" to the land (e.g., buildings and structures) at the local level without waiting for GSA consent. DOE-ID will dismantle and destroy buildings or structures that cannot be reused. Buildings and structures suitable for use by others will be reported to GSA for their disposal action. This precludes the need to go through a long approval process.

Although wastes are generated by the dismantlement and demolition program, the program also keeps some materials from Site landfills by recycling. In 1995, the program recycled $42,000 \mathrm{~kg}(93,000 \mathrm{lb})$ of scrap metal and saved approximately $\$ 70,000$ by recycling concrete. Implementing the new concrete recycling program is expected to save several million dollars over the next 10 years, and it produces useful material from what was once considered waste. More detailed discussion of this program can be found in the "Recycling Re-use of Excess Materials" section.

Several projects at INEL facility areas were completed in 1995 by personnel of the decontamination, dismantlement and demolition program. These are summarized in the following paragraphs.

ARA-II. Decontamination and dismantlement of an office building, a 4000-L (1,000gal) tank of radioactive liquid waste and three electrical transformers were completed. The project shipped 205 boxes of contaminated debris to the RWMC as a result of program activities at ARA-II.

ARA-III. Decontamination and removal of two buildings and a cooling tower basin at Auxiliary Reactor Area III were completed in 1995. Demolition of all remaining buildings at both ARA-II and -III should be completed by the end of 1996 .

CFA. Demolition and removal of the CFA maintenance shop (CFA-654) that was originally a Navy warehouse was completed in March 1995. The project also performed an emergency demolition of the CFA-618 storage facility, which had been damaged by wind. The scheduled demolition of the building was reprioritized as a result of the damage and was completed in July 1995.

EBR-I. Demolition and dismantlement of several buildings around the EBR-I facility were performed in 1995 . The demolition of Building AEF-603 was finished in June 1995 and asbestos removal in buildings WMO-601 and WMO-601A was complete about the same time. Demolition of the buildings began in early July and was completed, with the exception of disposing of some contaminated 
waste accumulated during the process, by the end of September 1995. The area was leveled to grade and is ready for seeding.

Fire Station \#2. Deactivation, dismantlement, and demolition activities at the old Fire Station \#2, including the demolition of two safety training trailers, were completed by the middle of September 1995. The area was graded and "green field" seeding was done in the fall to return the landscape to a more natural condition.

ICPP. In February 1995, personnel began removing obsolete equipment and material from the ROVER facility (CPP-640). Much of the material had been exposed to radioactive material and had to be boxed for disposal at the RWMC. A significant number of boxes will be generated during the disposal process at this facility. Vessel removal had been completed by the middle of June 1995 , and demolition of instrumentation panels to clear the front of the process cell for access was essentially complete by the end of September 1995. The deactivation of the facility is scheduled to be completed in 1999.

TAN. The facility closure list for TAN was prepared for coordination with the State Historical Preservation Office to review each building for its historical significance, if any. A total of 18 buildings were identified for closure in 1995, and 15 of these had been inactivated and closed by October 1, 1995.

TRA. The project to deactivate the Advance Reactivity Measurement Facility/Coupled Fast Reactivity Measurement Facility began in June 1995. The project required removal of the fuel currently in the reactors and trans- ferring it to ICPP. The objective of the project is to stabilize the facility and prevent any possible fuel storage violations.

During September 1995, the last of the partially dismantled red-iron skeleton structure of TRA-617, a former warehouse, was removed. Volunteer labor dismantled and removed the structure at minimal cost to the federal government. The former warehouse had been left as an iron skeleton for more than five years when funding to remove the building was canceled.

\subsection{WASTE MANAGEMENT PROGRAM INFORMATION}

\section{General Information}

The goals of the Waste Management Program are to manage wastes at the INEL, ensuring that workers and the public are protected, and that the environment is not further impacted. INEL waste management activities consist of :

- reducing the total amount of wastes generated

- treating wastes already generated by reducing their toxicity, mobility, or volume

- storing wastes awaiting development of new disposal or treatment options

- disposing of wastes

Another challenge faced in managing wastes at the INEL is involving the citizens of Idaho in the search for solutions to significant waste management issues. Several methods are used to keep the public informed about INEL activities and involved in making decisions. Some of these are discussed in Section 3.3 . 
Chapter 3: Environmental Program Information

\section{Accomplishments of the Waste} Management Program

The Federal Facility Compliance Act. This 1992 act, which amends RCRA, requires the preparation of site treatment plans for the treatment of mixed wastes at DOE facilities which store or generate these wastes. Mixed waste contains both hazardous and radioactive components.

The INEL Proposed Site Treatment Plan was submitted to the State of Idaho and EPA on March 31, 1995. Copies of the Plan were also sent to various reading rooms throughout Idaho, to the INEL Site Specific Advisory Board (a citizens' review board), and to the Shoshone-Bannock Tribes. This plan outlined DOE-ID's proposed treatment strategy for INEL mixed waste streams and provided a preliminary analysis of potential offsite mixed low-level waste treatment capabilities.

The final INEL Site Treatment Plan formed the basis for State of Idaho and DOE consent order negotiations for mixed waste treatment at the INEL. The Federal Facility Compliance Act Consent Order and Site Treatment Plan was finalized and signed by the State of Idaho on November 1, 1995. Two changes to the administrative sections of the plan were negotiated to resolve issues between the State and DOE-ID: (1) DOE reserved its right to challenge the approval authority of the State over offsite wastes, and (2) both parties agreed to modify the plan's schedules to be consistent with the Settlement Agreement and Court Order issued in October 1995 in the Spent Nuclear Fuel and INEL EIS litigation discussed in Section 2.2 of this report.

Public involvement activities in the Federal Facility Compliance Act planning process at the INEL were integrated into the overall public participation program already in place for environmental restoration and waste management activities. Public focus group meetings were held on the Conceptual Site Treatment Plan in 1993; briefings on the Draft Site Treatment Plan were held in 1994 in Twin Falls, Boise, Moscow and Idaho Falls to solicit public opinion early in the process. DOE-ID also briefed the INEL Site Specific Advisory Board on the Proposed Plan, and responded to its comments and concerns.

Numerous information and update sheets were mailed to stakeholders in 1995. The INEL Site Treatment Plan Summary was published in November 1995, mailed to the stakeholders' mailing list, and made available electronically.

In accordance with the INEL Site Treatment Plan, the INEL began receiving offsite mixed waste from two Naval Nuclear Propulsion Program facilities for treatment in January 1996. The INEL expects to receive mixed waste shipments from other sites within the DOE complex including Los Alamos National Laboratory, Rocky Flats National Laboratory, Savannah River National Laboratory, Lawrence Livermore National Laboratory, and Naval Nuclear Propulsion Program facilities.

Storage and treatment of the majority of the offsite waste will be performed at the Waste Reduction Operations Complex using technologies of incineration, mercury retort, macroencapsulation, stabilization in Portland cement, neutralization, and carbon absorption. Additional offsite mixed wastes could be treated at the Advanced Mixed Waste Treatment Facility planned for construction at the INEL.

\footnotetext{
" Internet http://www.inel.gov then click on "INEL and the Environment" and select the desired document. 
Advanced Mixed Waste Treatment Project. A DOE-ID evaluation team assessed cost and feasibility studies of the private sector for treating alpha and transuranic mixed wastes. The final report, issued in May 1995, stated that the private sector could treat not only alpha mixed low-level wastes but transuranic mixed wastes more cost-effectively than could be done by the INEL.

Project development activities for the Idaho Waste Processing Facility, a 3,250- $\mathrm{m}^{2}$ $\left(35,000-\mathrm{ft}^{2}\right)$ storage facility to be located at the RWMC adjacent to the Waste Characterization Facility were discontinued. The current plans for the Waste Characterization Facility are also being re-evaluated. As a result of the privatization effort for the treatment of alpha and transuranic low-level mixed wastes, a decrease in scope of this facility would still satisfy the need for characterization of waste before transfer to the private sector for treatment.

The Request-for-Proposal for the Advanced Mixed Waste Treatment Project was issued in January 1996. The overall vision for the INEL Project is to treat alpha low-level mixed and transuranic waste for final disposal by a process which provides the greatest value to the Government. This will be accomplished through a private sector treatment facility with the capability to treat specified INEL waste streams and with flexibility to treat other INEL and DOE regional and national waste streams. The services shall: (1) treat waste to meet the most current WIPP Waste Acceptance Criteria, RCRA Land Disposal Requirements, and required Toxic Substances Control Act standards; (2) reduce waste volume and life-cycle cost to DOE; and (3) perform tasks in a safe, environmentally compliant manner.
An unclassified preproposal conference and tour of the RWMC were held in early March 1996. Due dates in April and May 1996 are specified for different volumes of the proposals. The proposals will be evaluated by the Source Evaluation Board.

Plutonium Focus Area. In October 1995, DOE-HQ announced that the INEL (DOE-ID, LITCO, and ANL-W) had been selected to manage the Plutonium Focus Area for DOE. This does not mean more plutonium will be sent to the INEL. The national mission of the Plutonium Focus Area involves finding ways to stabilize plutonium-contaminated materials once used to produce weapons. While the materials of concern are not at the INEL, nor will the research be done here, the INEL will lead the $\$ 22$ million annual program and will direct efforts to get these materials safely stored.

The job is complicated by the fact that hundreds of different materials such as incinerator ash and cans of salts contaminated with plutonium are proliferation-sensitive, therefore requiring special security safeguards. Furthermore, some of the substances, metals and oxides, remaining in the weapons labs when the defense assembly lines stopped in 1989, are very hazardous and are corroding the hardware. The current storage containers were not designed to withstand the effects of deterioration during a long-term work stoppage.

The key objectives for the focus area include expediting remediation, standardizing solutions to the problems across the DOE complex, and keeping costs down. Other objectives involve encouraging industry and university participation and involving the public and tribes in technology decisions. The 
Chapter 3: Environmental Program Information

Plutonium Focus Area will work with citizens' advisory boards complex-wide to ensure that stakeholders become partners in solving these problems.

Mixed Waste Focus Area. DOE-HQ announced in December 1994 that the INEL had been selected as the lead laboratory for mixed waste technology development. DOE-ID, supported by LITCO, formed a group called the Mixed Waste Focus Area that is coordinating the national effort to treat mixed waste. At the INEL alone, there is enough mixed waste to fill about 600 railroad boxcars.

Business for the group means deciding which of the technologies that are designed to characterize and treat radioactive and hazardous mixed waste stored throughout the DOE complex should be funded. A new twist to the program requires that all mature technologies have a "customer" who plans to implement the technology before the Focus Area will commit funds. Customers may be in various offices at DOE-Headquarters or in private industry. Immature technologies will receive funding for further development only if the technology is likely to fit a specific customer need. An example of this approach was the funding of a technology called "base hydrolysis" at the PANTEX Plant in Amarillo, TX. Base hydrolysis is designed to neutralize the nonnuclear explosive component of atomic weapons. The technology was destined for the unfunded list until a customer in the DOE Albuquerque Operations Office committed to using the technology if the focus area funded a demonstration that was successful.

Before making these funding decisions, members of the Mixed Waste Focus Area spent the summer of 1995 visiting seven DOE field offices, observing large mixed waste inventories, and meeting with customers in environmental management to clarify their technology needs. The efforts of the group resulted in two comprehensive reports: the Integrated Baseline Report, Phase I, and its companion report, The DOE Complex Needs Report, which lists technology deficiencies in mixed waste treatment. Phase II of the technical baseline will include the scope and schedule for technology development projects to address the identified deficiencies. Some of the projects will be contracted to private industry and others through the DOE laboratory system.

DOE Accreditation Programs. The Radiological and Environmental Sciences Laboratory (RESL) at the INEL is the national lead laboratory for two major laboratory accreditation programs. The Department of Energy Laboratory Accreditation Program (DOELAP) for personnel dosimetry has operated since 1986. The bioassay portion of that program is being developed at RESL, and the Handbook for the Department of Energy Laboratory Accreditation Program for Radiobioassay was revised and is currently at DOE-HQ for review. The RESL bioassay group has completed several pilot programs where samples were sent to DOE-complex laboratories for analysis. Each of these pilots followed the protocols in the draft standard ANSI N-13.30, "Performance Criteria for Radiobioassay." The final version of this standard is scheduled to be published in late July 1996.

The second program is the Mixed Analyte Performance Evaluation Program (MAPEP). During 1995, RESL distributed samples containing known quantities of specific analytes, to the participating laboratories for analyses. By December 1995, approximately 100 laboratories were participating in the program. 
Participants send results of their analyses of the test samples to RESL for computerized statistical analysis to determine quality of the results for each laboratory and for the group as a whole. During 1996, the entire program (sample preparation, distribution and reporting) will be relocated to RESL.

Cost cutting at DOE Headquarters has resulted in the relocation of two more national programs to RESL. The DOE Methods Compendium (currently at Hanford's Pacific Northwest Laboratories) and the Integrated Performance Evaluation Program (currently at Argonne National Laboratory-East) will be integrated into RESL in 1996.

\section{National Low-Level Waste Management Program. The INEL provided technical support for the commercial low-level waste disposal siting and disposal facility develop- ment in several states including Nebraska, California, Texas, Pennsylvania, and North Carolina. Work began with the DOE Office of Civilian Radioactive Waste to establish the Yucca Mountain, Nevada, repository as the final resting place for waste that does not meet Nuclear Regulatory Commission criteria for shallow land burial disposal. This is waste, referred to as Greater-Than-Class-C, that does not fall into the high-level waste category either, and is a sort of "orphan" for which DOE has a legal disposal obligation.}

\section{Waste Minimization/Pollution Prevention}

Key approaches to meeting Waste Management Program goals are waste minimization and pollution prevention programs. Current INEL activities of these programs include:

- identifying and analyzing options to reduce the volume of waste generated
- listing unused and excess chemicals and materials in the Material Exchange Program as available for use in other projects or facilities

- maintaining a database in which hazardous solvents are tracked and identified and nonhazardous materials substituted when possible

- practicing sitewide recycling of as many materials as possible

- substituting reusable and nonhazardous materials for hazardous and disposable materials when possible in the equipment and vehicle maintenance programs

- sharing lessons learned in pollution prevention with surrounding communities and industry

- examining production processes at the INEL to determine whether improvements in process efficiency can result in a significant source reduction of wastes.

In January 1995, EPA and the Council on Environmental Quality indicated their intent to make the federal government the national leader in implementing pollution prevention policies and practices in order to promote the sustainable use of natural resources and to protect human health and the environment. EPA also indicated its intent to consider pollution prevention while reviewing all NEPA documents. In response, DOE-ID decided to incorporate pollution prevention into its NEPA process, and personnel began to review all draft NEPA procedures, plans, and checklists for incorporation of pollution prevention principles. This approach will initiate the thought process of source reduction in the beginning phases of a project and will promote environmental protection-the underlying intent of NEPA.

At the SMC facility at TAN, personnel installed a high-pressure water jet to replace a 
Chapter 3: Environmental Program Information

nitric acid etch system used to clean depleted uranium plates prior to configuring them for the armor units. The application of this technology has allowed the SMC project to eliminate the use of a hazardous chemical and to prevent the generation of a mixed waste.

In the analytical laboratory at RESL, a new chemical procedure for the determination of ${ }^{90} \mathrm{Sr}$ in soil and water samples was developed. It eliminates the production of a hazardous waste without sacrificing either sensitivity or accuracy.

As part of the DOE initiative to comply with EPA rules concerning the reduction of chlorofluorocarbon emissions, DOE-ID and LITCO reviewed the impact of the initiative on INEL systems in terms of cost and the number of units to be modified. In 1995 , DOE-HQ published a guidance manual on ozone-depleting substance management.

Some work was done at the INEL in 1995 on phasing out halon fire suppressent systems. Halon is considered a Class I ozone-depleting chlorofluorocarbon substance. When possible, other types of fire suppressant systems were substituted, and the number of halon systems at the INEL were minimized. The EPA regulations require that maintenance and care of refrigerant equipment be performed by certified technicians using certified equipment. LITCO technicians and equipment meet that requirement.

An example of waste minimization at work was a change made in material receipt procedures at the RWMC. The change made it permissible for personnel to unpack a shipment of drum overpacks that were individually wrapped in cardboard. By doing this, they could recycle the cardboard, and the waste occupies considerably less space in the lowlevel waste disposal pits.
Another example was the incineration of ICPP waste by the Scientific Ecology Group, Oak Ridge, Tennessee, in late August 1995. Thirty-six containers were consolidated into 24 containers before shipping, and $930 \mathrm{~m}^{3}$ $\left(1220 \mathrm{yd}^{3}\right)$ of waste were reduced to about $3 \mathrm{~m}^{3}\left(4 \mathrm{yd}^{3}\right)$ of compacted ash to be returned for final disposal at RWMC. This is more than a 300 to 1 volume reduction.

\section{Recycling and Re-use of Excess Materials}

The DOE Rocky Flats and PANTEX contractors agreed to transfer excess beryllium from the PANTEX plant in Texas and the Rocky Flats Plant in Colorado to the INEL for future operations at TRA. The first shipment from both facilities occurred in September 1995. Use of excess material from other DOE facilities in this manner will result in savings of about $\$ 2$ million dollars to the INEL.

Start-up of the portable concrete/asphalt crushing plant was begun in June 1995. The first use of this plant was to minimize bulk waste at EBR-I during demolition activities. Material generated during the demolition of buildings, footers, and foundations is crushed, so it can be used as fill and grade material at the demolition site and elsewhere on the INEL. This eliminates hauling in new fill material and saves space at the CFA landfill where the demolition debris would have been taken. Metals are separated from the concrete by a powerful magnet and recycled. Although the plant will not be operated on a daily basis, construction analysts project potential savings of several million dollars over the next 10 years.

During 1995, a test burn of pelletized paper and other nonradioactive waste was performed at the ICPP Coal-Fired Steam Generating Facility (CFSGF). The INEL was 
awarded funding in May 1996 to proceed with the process to convert nonrecyclable waste paper, wood, office trash, scrap lumber, wood chips, etc., to fuel. The process is similar to one commercial industry uses to make wood pellets for household stoves. About 37,000 $\mathrm{m}^{3}\left(48,000 \mathrm{yd}^{3}\right)$ of combustible nonrecyclable, nonradioactive waste is now generated at the INEL annually. Sixty-five percent of this waste can be pelletized and burned with coal as fuel. In addition to the saved landfill space, pelletizing and burning has the potential to save about $\$ 1.6$ million in annual disposal costs. In addition to the cost savings, the mixture of coal and pellets burns cleaner and more efficiently than the present fuel. Burning pellets at CFSGF will reduce sulfur and nitrous oxide emissions and heavy metal releases.

The INEL's disposal practice was changed during 1995 to make its scrap metal available for excess property resale instead of burial.

DOE-ID sent a memorandum to DOE-CH in September 1995, asking them to arrange for the transfer of New Brunswick Laboratory enriched uranium nuclear material stored at ICPP to some other site by the end of 1995 . Removing this unneeded material from ICPP will facilitate cutting security costs.

Depleted uranium scrapped from the Army Abrams Tank Program armor manufacturing process at the INEL's SMC will be transferred to the Army contractors who are manufacturing armor penetrators. Depending on the final production quantities authorized by the Department of Defense for both armor and penetrators, the combined requirements of the Penetrator Program, the Abrams Tank Program, and the upcoming Breacher Program should make it possible to recycle the majority of the depleted uranium scrap inventory at the SMC facility.
Asset Sales. In August 1995, DOE-HQ asked DOE Oak Ridge Operations Office to conduct the first DOE asset sale of precious metals. The INEL provided data related to physical configuration, refining requirements and exact amounts of metals at the INEL. Most of the metals previously reported by the INEL in April 1995 did not have an acceptable certification and/or were not of the desired configuration. They were considered, therefore, as scrap rather than pure metal.

During a fall 1995 survey for radioactive contamination prior to transferring ownership of the Advance Reactivity Measurement Facility/Coupled Fast Reactivity Measurement Facility from one office at DOE-Headquarters to another, a number of capsules were found by the technician in a cabinet. They were not contaminated, and personnel opened them. Several contained a gold-colored powdered material. A historical background check on materials formerly used at TRA suggested the possibility the material could be pure gold. Laboratory tests confirmed the powdered material was, indeed, gold. It was sent to Oak Ridge National Laboratory to be included in the DOE asset sale of precious metals.

Lead Management Project. The INEL Lead Management Project assures appropriate and uniform operations and management of waste lead at the INEL, ensures the lead supply is managed and stored in approved facilities, and implements treatment processes and technologies for recovery, storage, or disposal.

Cask Dismantlement.-A demonstration program conducted by Babcock \& Wilcox Idaho, Inc. showed that spent nuclear fuel transfer casks could be safely dismantled and the lead shielding recovered. With completion of the demonstration, Babcock and 
Chapter 3: Environmental Program Information

Wilcox Idaho and EG\&G Idaho began a pilot program to dismantle 20 more casks of various configurations to provide information and experience for eventual dismantlement of all out-of-service casks at the INEL (and possibly other DOE sites). An evaluation of the program in early September 1994 revealed that dismantlement of the 20 casks (completed one year ahead of schedule) was done at a lower total cost than projected for half the project. Results from analyses performed on samples taken from the $25,000 \mathrm{~kg}(55,000 \mathrm{lb})$ of lead retrieved from the casks dismantled, certified that $23,000 \mathrm{~kg}(51,000 \mathrm{lb})$ were free of DOEadded radiological contamination and suitable for recycling. In July 1995, the clean lead from the casks plus other excess clean lead was placed on trucks and sent to a private sector lead recycler.

In March 1995, LITCO personnel began dismantling the remaining excess nuclear fuel shipping casks in storage at TAN. Twelve casks had been dismantled by the end of the fiscal year (September 1995) and another 12 are planned for 1996.

Review of Technologies for Lead Decontamination and Reprocessing.-The INEL Lead Management Program reviewed suitable technologies for lead decontamination and reprocessing in late 1994 and early 1995. Their conclusions from evaluations of available current technologies suitable for the treatment, storage, and disposal of contaminated excess lead at the INEL showed that the acid-etch, $\mathrm{CO}_{2}$-pellet blasting and other abrasive surface decontamination techniques work well for lead configurations with a low surface to volume ratio (e.g., brick and plate) and relatively smooth surfaces. Demonstrations of technologies suitable for processing finely divided lead (e.g., shot, wool, small irregular chunks) are currently needed. Several private sector companies with potential capabilities to address this requirement have been identified.

In August 1995, DOE-ID approved a new cooperative agreement award for transferring to the commercial sector a technology developed at the Brookhaven National Laboratory in New York (a DOE facility). The agreement with Envirocare of Utah calls for the use of that technology, which encapsulates the waste in melted recycled plastic for disposal in a landfill, to prove the process works. The INEL will ship to Envirocare a total of $226,800 \mathrm{~kg}(500,000 \mathrm{lb})$ of contaminated lead as part of the DOE-funded program to demonstrate the new capability and technology.

\section{Lead Shot Surface Decontamination} Demonstration Project.-The INEL established a no-cost contract with CORPEX, a private contractor, to demonstrate their proprietary chemical for surface decontamination of lead shot. This work will be performed under agreement with Idaho State University, Pocatello, Idaho.

\section{Recycling Contaminated Lead and} Stainless Steel Inventories.-In November 1995, a proposal was begun to use low-level mixed waste lead and low-level mixed waste stainless steel materials to fabricate containers to repack and store remote handled transuranic waste. Currently, some of the drums containing transuranic waste stored at the RWMC are beginning to rust and leak. The proposal suggests that waste steel and waste lead from DOE operations be fabricated into shielded containers to repackage and store this waste.

There are a number of benefits to this proposal. First, contaminated waste lead currently in RCRA storage at the INEL could be used, helping to remove the storage costs and 
future disposal or treatment costs. A plentiful supply of low-level mixed waste contaminated stainless steel is available to use for the manufacture of the storage containers. Therefore, there would be a reduction in the costs of materials for fabrication.

The private sector has the capabilities to handle and fabricate such containers. The proposal will be explored for the cost savings benefit between the several affected programs of DOE. A combined cooperative effort with combined funding support could make this proposal an economical and environmentally responsible solution to several waste treatment, storage, and disposal issues currently facing the INEL and DOE.

Alternative-Fueled Vehicle Program. Regulations from the Clean Air Act and Executive Orders list specific requirements for 1995-98 with respect to ensuring efficient and effective fleet operations at DOE facilities. These requirements include reducing gasoline and diesel fuel consumption and converting operations to alternate-fueled vehicles.

In August 1994, the Alternate Fueled Vehicle Fleet Conversion program began operations to convert about 25 existing fleet vehicles from gasoline or diesel to using other fuels such as liquid petroleum gas, liquid natural gas, or compressed natural gas. Conversion of vehicles began in January 1995 . These vehicles will be bi-fuel vehicles that are able to operate on either natural gas or gasoline.

The INEL held a small ceremony commemorating the arrival of the first bus ever to be driven cross-country on liquefied natural gas (LNG) on September 5, 1995. This bus is the first product of a Cooperative Research and Development Agreement with Detroit Diesel to rebuild six buses to operate on LNG.
According to the agreement, Detroit Diesel will furnish state-of-the-art experimental engines, and the INEL will test these prototype engines using liquid natural gas as fuel in an experimental group and diesel fuel in a control group. Arrangements have been made to use the INEL LNG-fueled buses to transport NBC press personnel at the 1996 Summer Olympic Games in Atlanta, Georgia.

The INEL alternate fuel program plan also includes the installation of a liquid natural gas fueling station at the new Transportation Complex at CFA.

\section{Waste Treatment Accomplishments}

Offsite Low-Level Waste Treatment. A twoyear subcontract was awarded to Scientific Ecology Group (SEG) of Oak Ridge, Tennessee in June 1994 for transportation and treatment services for the backlogged lowlevel waste at the Waste Experimental Reduction Facility (WERF) facility and other INEL facilities. The waste accumulated as a result of the WERF shutdown, and the subcontracted treatment was to provide a costeffective means of reducing the volume of the treated waste as much as possible before final disposal at the INEL. By using offsite services for this purpose, the INEL was able to make WERF operational for treatment of other wastes, such as mixed wastes. Shipment and treatment of about $2,800 \mathrm{~m}^{3}\left(100,000 \mathrm{ft}^{3}\right)$ of incinerable low-level waste was completed by the end of December 1994. The 1995 campaign for shipment and treatment of WERF wastes totaled approximately $740 \mathrm{~m}^{3}$ $\left(66,096 \mathrm{ft}^{3}\right)$.

During 1995 , a variety of wastes from other facilities were also sent to the SEG for treatment. Forty-eight drums of liquid lowlevel waste were shipped for incineration. In 
Chapter 3: Environmental Program Information

September, the fourth campaign for treatment of INEL low-level waste began.

A total of about $60,550 \mathrm{~kg}(133,500 \mathrm{lb})$ were incinerated in this campaign. The empty containers were shipped back to the INEL for future use. One return shipment included the return of the compacted ash for disposal at RWMC.

In July 1995, 2,745 L (725 gal) of mixed liquid low-level waste was shipped to Diversified Scientific Services, Inc., Kingston, Tennessee, for treatment and disposal. This action eliminated three of the waste streams from the INEL inventory (one from TRA, the hexone waste stream from ICPP, and a decontamination solvent waste stream from ANL-W). The incineration residual was disposed at Envirocare of Utah, and the metal containers will be melted at SEG and sent to Los Alamos National Laboratory for melting into ingots for recycling within DOE. The INEL will save about $\$ 280,000$ through this contract.

Hanford/INEL Negotiations. Near the end of 1995, preliminary negotiations were begun between DOE-ID/INEL and DOE-Richland/ Hanford. A cooperative effort to treat and dispose of wastes may be a cost-effective approach for both laboratories. Hanford is interested in taking the INEL's low-level waste for disposal. In return, the INEL could accept mixed low-level wastes from Hanford for treatment at WERF. The residue of those wastes would be shipped back to Hanford for final disposal. The advantages to the INEL include cost savings for DOE, removing some stored waste from the INEL, and finalizing a closure plan for the RWMC. The advantage to Hanford would be treatment of some of their stored wastes. This cooperative effort is only one of several options being considered to solve the INEL's low-level waste problems.

Waste Experimental Reduction Facility (WERF) Restart Program. The WERF facility, which was shut down for safety improvements in February 1991, was restarted and began sizing and compacting low-level waste in November 1994. The compacted materials and the ash from the incinerator will be disposed of at RWMC.

In February 1995, WERF personnel reevaluated their plasma-arc cutting method. The WERF torches used compressed nitrogen, argon, and hydrogen gas to create extremely hot flame temperatures resulting in clean, smooth cuts. However, at WERF, such highquality cuts are unnecessary because the cutup metal is sent for disposal. By switching to the use of compressed air, sizing is less expensive and safer for personnel than using more hazardous compressed gases, such as hydrogen.

A feasibility study considered upgrading the old WERF sizing facility to house the amalgamation, encapsulation, neutralization, and mercury retort units, while still doing mixed low-level waste sizing and stabilization at existing WERF units. The study showed about $\$ 1$ million savings over the previous plan to perform upgrades to another facility. Another advantage was that WERF would become a comprehensive, consolidated, mixed low-level waste treatment facility.

In an effort to reduce onsite storage of hazardous waste and to increase direct shipments from the waste generators to the commercial treatment/disposal facility, the WERF Waste Storage Building will be used to store "problem" wastes from the INEL. Everything else will be shipped directly to commercial treatment/disposal facilities. This 
will enable the INEL to close the Hazardous Waste Storage Facility at CFA two years sooner than expected and will save about $\$ 1$ million dollars in operating costs.

After test runs that incinerated nonhazardous materials at WERF, an incineration campaign for low-level waste began in July 1995 and was successfully concluded in August. This restart followed signature of the Record of Decision for the INEL EIS. Incineration of mixed low-level waste began in September 1995. This was the first campaign for incineration of mixed low-level wastes since 1990. The primary constituent of this mixed-waste campaign is an injection well sludge contaminated with 1,1,1- trichloroethane and trichloroethylene. The incineration process results in a waste volume reduction of 300 to 1 with the added benefit of destroying hazardous organic components.

In October 1995, personnel processed the first drum of incinerator ash in four years. The ash was from incinerator campaigns prior to the 1991 shutdown, the five-day integrated test, the surrogate waste burns, the two lowlevel waste campaigns and the one mixed lowlevel waste campaign. The ash contained chromium and will undergo stabilization prior to disposal at RWMC.

The INEL received its first shipments of mixed Iow-level waste from Charleston Naval Shipyard and Mare Island Naval Shipyard for treatment at the WERF facility in January 1996. The Federal Facility Compliance Act Consent Order and INEL Site Treatment Plan provide for storage of pre- and post-treated residues from this waste.

Dry Rod Consolidation Technology Project. Project personnel have been evaluating options for segmenting and packaging nonfuel bearing component wastes to allow for permanent disposal of some materials and storage of the remainder at RWMC. Because the radiation fields may be as high as 7000 $\mathrm{R} / \mathrm{hr}$, the materials planned for disposal exceeded the waste acceptance criteria of the RWMC. In the meantime, waste from shearing the highly radioactive fuel assembly skeletons, stored in the TAN pool, was accumulated in the TAN Hot Shop North Silo. The shearing process, which reduced the volume of the assemblies, was completed in December 1995.

Sodium/Potassium Wastes. In September 1995 , the Sodium/Potassium $(\mathrm{Na} / \mathrm{K})$ Wastes were moved from their storage location in the Army Reentry Vehicle Facility Site bunker to ANL-W for treatment. The treatment process includes reacting the waste material with water, neutralizing the resulting solution, and solidifying the neutralized solution. The treatment of the $\mathrm{Na} / \mathrm{K}$ wastes was completed in early 1996. The solid radioactive waste resulting from the treatment process will be sent to RWMC for disposal.

In December 1995, TAN Operations group reprioritized the removal of the $\mathrm{S} 1 \mathrm{G}$ sodium tank from the TAN-647 RCRA storage area to ANL-W for treatment and disposal. The task should be completed in 1996. This will close an issue with the State of Idaho concerning a RCRA Notice of Violation item related to the roll-up door at the TAN-647 building.

Cold Waste Handling System Project. The remodeled System was put into operation at ICPP. This system allows increased volumes of cold (nonradioactive) waste to be inspected, recycled, shredded, compacted, and segregated, thereby reducing the amount of material being sent to the landfill for disposal. Any 
INEL generator of sanitary wastes destined for a landfill will be able to use the system.

\section{Waste Storage Accomplishments}

Resource Conservation and Recovery Act Activities. Those activities related to the permitting of hazardous wastes at the INEL are discussed under the RCRA subtitle in Chapter 2, of this report.

On November 20, 1995, personnel at RWMC met the first of two milestones required by the Consent Order for moving waste from the RWMC Certified and Segregated Building into RCRA compliant storage modules, WSF-628 and WSF-629. The milestone was reached six weeks ahead of schedule with a cost savings of $\$ 500,000$.

Dry Fuel Storage Agreement. An agreement between DOE-ID and the Governor of Idaho for dry storage of some types of spent fuel was signed in 1995. The Court Order, which had required the INEL to move fuel stored underwater in CPP-603 basins to CPP-666 by December 31, 1995, contained a clause allowing DOE and the State to agree on alternate storage for any fuel deemed unsafe for underwater storage. The agreement will allow the dry storage of some specific spent fuels that were showing signs of significant corrosion in the CPP-603 basins. The movement of these fuels into dry storage should be complete by mid-year 1998 .

\section{Spent Nuclear Fuel Settlement Agreement.} On October 16, 1995, a settlement agreement was signed by DOE, the Navy and the State of Idaho to resolve issues surrounding a court injunction that prohibited the receipt of spent nuclear fuel for storage at the INEL. This concludes seven years of conflict with the
State concerning spent nuclear fuel and radioactive waste shipments into Idaho.

The agreement allows the INEL to actively pursue the reracking of the CPP-666 fuel storage pools for the continued receipt and storage of spent naval fuels while maintaining sufficient storage capacity to accommodate fuel transfers from the CPP-603 facility. The agreement also allows the INEL to receive miscellaneous other spent fuel including fuel from the Savannah River Site, the West Valley Demonstration Project, and foreign research reactors. A new date for completing the process of calcining all remaining nonsodium bearing liquid high-level waste was set in the agreement.

Three Mile Island Spent Fuel Storage Facility. In June 1995 DOE decided that the most economical option for dry storage of Three Mile Island spent fuel stored at the INEL was to build a new facility at ICPP. Newport News Shipbuilding was the winning vendor in the procurement to construct the facility.

\section{Waste Disposal Accomplishments}

Although it is DOE's goal to eliminate the generation of wastes, ongoing operations result in the creation of waste. This waste ultimately requires disposal and may require permanent isolation from people and the environment in some cases. Currently, only industrial and low-level radioactive wastes are being disposed at the INEL. Other waste types are being stored for eventual disposal at the Site or elsewhere, or until treatment technologies are available.

Industrial Waste. The majority of nonradioactive and nonhazardous industrial wastes do 
not require treatment and go directly to the CFA Landfill Complex for permanent disposal. The capacity of the landfill will be sufficient for approximately 30 years or more as waste minimization and compaction efforts continue. Much of the paper and cardboard used at the INEL is being recycled rather than sent to the landfill. During the past three years, the INEL has recycled over $680,400 \mathrm{~kg}$ $(1,500,000 \mathrm{lb})$ of paper and cardboard. Currently, personnel are examining the possibility of converting paper and cardboard into pellets to be burned and used to generate electricity.

Low-Level Waste. Approximately $40 \%$ of low-level wastes (those containing less than $10 \mathrm{nCi} / \mathrm{g}$ of radioactivity but no hazardous waste), generated at the INEL are buried at RWMC in shallow pits. The remaining $60 \%$ will be buried at RWMC following treatment for volume reduction. For example, the compacting and sizing processes at WERF reduce the volume of wastes before disposal. Additionally, some low-level wastes are shipped offsite to be incinerated, and the residual ash is returned to the INEL for disposal. The RWMC is expected to be filled to capacity by the year 2030. Future disposal of low-level waste is being evaluated by DOE, the State and other regulators.

Offsite Waste Disposal. Depending on the type of wastes and specific contaminants, it may be more economical to send wastes offsite for treatment and/or disposal. For example, the INEL may not have appropriate technologies available or a suitable disposal site.

In September a truckload of contaminated, classified waste metal scrap was shipped from the SMC facility to SEG in Tennessee for disposal. A representative from DOE-ID traveled to Oak Ridge to witness the destruction of the waste and to assist in ensuring security of the material during handling within the plant.

\section{Waste Isolation Pilot Plant (WIPP) Sup-} port. Management of transuranic waste is an important function of the INEL Waste Management Program. This includes supporting the WIPP near Carlsbad, New Mexico, anticipated to be the disposal site for most transuranic waste.

In 1991, ANL-W began their WIPP Waste Characterization of transuranic and alpha-lowlevel mixed wastes. Over 130,000 containers, retrievably stored at the RWMC, need to be characterized. Seventy-five 208-L (55-gal) drums of debris waste have been characterized in the Hot Fuel Examination Facility at ANL-W to date. The waste characterization area inside that facility was recently modified, and it is now expected that 90 drums per year can be characterized. Waste characterization data is required to do performance assessment modeling, and the modeling is necessary to get WIPP open as a permanent disposal facility.

Preparations for the WIPP Gas Generation Experiments were completed at ANL-W in 1995. The purpose of the experiments is to examine gas generation caused by decomposition of cellulosic waste, corrosion of metals, and radiolysis of water and waste that might impact performance of the salt beds at the WIPP waste repository. The startup review was done in early January 1996, and actual experimental operations began January 19, 1996. Fourteen experimental test containers were set up, and ANL-W personnel began collecting data. The experiments are scheduled to continue until the end of 1999.

The Plasma Hearth Process Project is another that was planned for treating wastes of 
the type to be stored at WIPP. The process is a high-temperature thermal treatment used to convert a variety of radioactive and mixed wastes into a stable, nonleaching, vitrified waste form. Portions of the project were planned for the INEL, including development of robotics for use in the high-temperature environment. The purpose of the overall project (complex-wide) is to develop, test, and evaluate a new concept for mixed waste treatment based on the vitrification of waste materials using fixed hearth direct current transferred arc plasma torch technology.

Bench-scale demonstration of the Plasma Hearth Process was conducted in the ANL-W Transient Reactor Test facility. Successful testing of the bench-scale unit was to have been followed by demonstration of a full-scale plasma hearth process unit, but due to major budget reductions, most portions of the project planned for the INEL have been put on hold or canceled.

A Plasma Hearth Process Open House was held in Idaho Falls on November 8, 1995. Major public concerns were centered on mechanical malfunction and backup systems. No opposition was expressed to the concept of plasma treatment and high temperatures needed for the technology.

\section{Waste-Related Research and Development}

A wide variety of research projects are conducted at the INEL to benefit major DOE-ID programs, e.g., Waste Management, Environmental Restoration, Spent Nuclear Fuels and Land Management issues. The Environmental Science and Research Foundation and its university affiliates primarily conduct ecological and radioecological research. LITCO conducts a wide range of projects including methods of waste disposal, robotics, alternate-fuel vehicles, and bioremediation of wastes. It is beyond the scope of this report to summarize, or even list, all the projects underway in 1995. A few major projects have been mentioned in previous sections of this report. Examples of others of general interest to the public have been included in this section.

\section{Protective Cap/Biobarrier Experiment.} The Environmental Science and Research Foundation is conducting an experiment to test four cap designs for low-level buried waste in semi-arid to arid climates. This experiment is the culmination of 17 years of ecological research related to waste management by Foundation staff and university affiliates.

In order to safely store wastes underground, it is necessary to effectively keep water from reaching the waste materials. The four cap designs being tested in this experiment include:

- the EPA-recommended barrier design, which uses a flexible membrane liner and a highly compacted clay layer

- a 2-m (6.5-ft) thick cap of soil

- a 2-m (6.5-ft) thick soil cover which has a 50 -cm (20-in) thick gravel-cobble barrier $0.5 \mathrm{~m}(1.6 \mathrm{ft})$ below the surface

- a $2-\mathrm{m}$ (6.5-ft) thick soil cover with a 50 -cm (20-in) biobarrier beginning $1 \mathrm{~m}$ (3 ft) below the surface.

Previous INEL research has shown that the 2-m cap of soil is more than adequate to store the maximum amount of water received on the INEL during the nongrowing season (October through April). The addition of the biobarriers are to prevent burrowing animals (e.g., ants and small mammals) from entering the stored wastes. 
Phytoremediation Experiment. Field activities for the phytoremediation project by MSE, Inc., at the TAN Technical Support Facility's disposal pond began in July. The purpose of the experiment was to determine the potential of using plants to substantially reduce concentrations of radionuclides such as cesium, strontium, and cobalt in soils. The plant species evaluated included sugar beets, alfalfa, fava bean, broccoli, cabbage, Canada mustard, Raskin mustard, and an indigenous control plant. Researchers removed the above-ground portion of the plants prior to the seeding stage, and the harvested plant material was analyzed. The final project report is due in 1996.

Landfill Stabilization Focus Area. The former Buried Waste Integrated Demonstration Program became a portion of the Landfill Stabilization Focus Area in early 1995. The INEL program assumed the lead for the Landfill Stabilization Focus Area in planning and implementing the demonstration of innovative technologies that may be used to reduce the estimated cost of remediation of chemical disposal pits and other problem areas on the Brookhaven National Laboratory site. Most of the technologies demonstrated were from the INEL program, but were also included from other Department of Energy, Office of Technology Development Programs.

The annual Landfill Stabilization Focus Area Technology Exposition was held August 23-24, 1995. The event featured demonstrations of technology systems being developed to remediate buried waste sites. More than 100 people attended, including personnel from NOAA and members of the National Academy of Sciences.
Little Bighorn Battlefield Survey. In March 1995, INEL personnel and equipment performed a geophysical survey of the Little Bighorn Battlefield site in Montana. The purpose of the survey was to try to locate a mass grave believed to contain the remains of 27 soldiers. The survey used methods that had been developed for the characterization of buried wastes in research programs at the INEL. Evidence was found consistent with human remains, but the decision against excavating was made. A monument will be erected at the site.

\subsection{MISCELLANEOUS PROGRAMS}

\section{Public Involvement in INEL Program Activities}

The updated INEL Community Relations Plan, which outlines how DOE will involve the public in its environmental restoration decision-making process, was completed in 1995. This version of the Plan underwent two comment periods and then was examined closely by a citizen group. The Plan was the focus of five workshops and informal briefings around the state. The revised Plan was made available to the public through a notice in the INEL Reporter of July/August 1995.

DOE-ID maintains five Information Repositories with collections of documents to provide details on cleanup projects. Select documents are also included in public libraries in Idaho Falls, Twin Falls, and Boise.

Articles in the INEL Reporter (a publicly available newsletter) also provide updates on Environmental Restoration Program activities, and in 1995, the Community Relations Plan 
Chapter 3: Environmental Program Information

published Kickoff Fact Sheets, Update Fact Sheets, and other documents which included details on various remedial projects at the INEL's Waste Area Groups. These publications are available in Idaho Information Repositories and in Public Reading Rooms.

Members of the public may call 1-800708-2680 to request specific documents. These documents are also available electronically".

The INEL Comprehensive Facility and Land Use Plan was developed during 1995 and published early in 1996 . This plan is intended to be the base plan by which decisions are made for facility and land uses. Public comments were incorporated into the final document.

In July 1995, the Environmental Science and Research Foundation organized an indepth discussion group, consisting of a diverse group of indiviudals and representatives of various organizations, to discuss all aspects of environmental surveillance at the INEL. Topics incorporated into the discussion included economics of the program, public communication strategies, perception of risk, and the duplication of effort between environmental surveillance groups at the INEL.

\section{Public Communication and Education Activities}

There have been many efforts on the part of INEL personnel to improve communication with members of the public. Tours of INEL facilities and LITCO Public Affairs Speakers Bureau presentations to schools and civic organizations have been used to increase public understanding of INEL activities.

\footnotetext{
Internet: at http://www. inel.goy then click on the "INEL and the Ervironment" button and select any of the documents listed.
}

In August 1995, DOE-ID personnel participated in an open forum with the Pocatello League of Women Voters Nuclear Waste Steering Committee. Following the forum, DOE-ID received a letter stating, in effect, "When we first got involved in this study, we had a tendency to look at being for or against nuclear power. Now we think that is probably irrelevant, and the more important issue is how to economically and safely deal with the waste materials."

The INEL also operates the EBR-I facility as a historic landmark and offers tours to schools and public visitors between the end of May and Labor Day each year. Visitors gain an increased understanding of nuclear research at the INEL and of the flora and fauna that live on the Site. Since 1979 when the facility was opened for summer tours, nearly 200,000 visitors from every state and dozens of foreign countries have gone through its doors.

Personnel from the Environmental Science and Research Foundation made more than 50 presentations in 1995 to audiences including professional societies, INEL tour groups, classrooms, and civic groups. In addition to the multimedia presentations, the Foundation staff designed and produced a portable display describing the INEL Offsite Environmental Surveillance Program. During 1995, the display appeared at 12 locations, including malls in six Idaho cities, one post office and in schools and public libraries, with staff members on hand to answer questions.

LITCO staff set up an INEL robotics display at the sixth anniversary of the Discovery Center in Boise on January 14, 1995. The purpose of this display was to allow viewers an opportunity to see some of the latest advances in INEL technologies.

DOE-ID and its contractors prepared a variety of newsletters, press releases, and 
publically available reports to provide the public with more detailed information on INEL activities than is frequently available in short TV or radio announcements.

During 1995, LITCO and DOE-ID produced many press releases and public reports in addition to the publications listed under the first subsection, "Public Involvement in INEL Program Activities." The Foundation also prepared and issued news releases to approximately 110 media outlets; and they published six issues of their bimonthly newsletter, Foundation Focus. The newsletter discusses topics related to the Foundation's portion of the INEL Environmental Surveilance Program and results (see Section 3.4), summarizes research accomplishments at the $\mathrm{NEL}$, discusses plans for future activities, and includes articles of general public interest dealing with the INEL, such as wildlife information and results of big game and raptor surveys.

The Foundation staff, who published the 1994 INEL Site Environmental Report, also published the report, In Summary: Idaho National Engineering Laboratory Site Environmental Report for Calendar Year 1994. The summary report highlighted the significant data and conclusions from the annual report. This summary was written so that the public could easily understand the results and interpretations of environmental data at the INEL.

In December 1995, the Foundation's Travelers' Information Radio Station for the INEL began broadcasting messages for passengers in vehicles traveling through the Site. This station broadcasts on a frequency of $530 \mathrm{AM}$ providing repeated three-minute messages on environmental information related to the INEL.
A major accomplishment for the Foundation in 1995 was initiation of a community monitoring program to inform southeastern Idahoans about, and involve them in, environmental surveillance at the INEL. Letters were sent to schools throughout southeastern Idaho soliciting interest in the project. Madison Middle School in Rexburg was chosen as the first location, an agreement was signed between the Foundation and the school, and construction of the community monitoring station was begun at the end of the year. A second station will be installed during 1996 in Blackfoot, Idaho, at the Mountain View Middle School.

Each station will consist of air and radiation monitors and some meteorological equipment. It will be operated by science teachers at the school, and data obtained from the station will be displayed near the station for the public to view the results of the monitoring. Data generated by the station will also be accessed through the school's local area network, allowing the school to incorporate the data into science classes dealing with topics such as weather and radioactivity.

Cultural Resources Pilot Program. A proposal from the Shoshone-Bannock Tribes to develop and operate a Cultural Resources Pilot Program was submitted to DOE-HQ in February 1995 for concurrence. DOE-ID will fund development of an all-Indian cultural resource survey organization at Ft. Hall. This pilot program is the first attempt by DOE to develop a cultural resource organization for Native Americans to conduct archaeological work on Indian cultural resources and to provide their perspective to the non-Indian archaeological community. The proposed program contains strong educational and self- 
Chapter 3: Environmental Program Information

sufficiency components and is planned to become self-sustaining as soon as possible.

In addition to the Cultural Resources Program, the INEL has offered short-term training courses for members of the ShoshoneBannock Tribes. In April 1995, a course titled "Radiation and Low-Level Radioactive Waste Management Fundamentals" was taught. Also in April, a one-day training class for the Shoshone-Bannock Emergency Response Organization was conducted by representatives of the INEL Radiological Assistance Program. The class addressed basic concepts of radioactivity and radiation detection theory, and was designed to better prepare tribal emergency responders for transportation incidents involving radiological materials on the Fort Hall Reservation.

\section{INEL-Sponsored Academic Programs}

During the past three summers, the INEL has hosted teams of high-school teachers and students who performed research projects that supported DOE program initiatives as well as various entities outside the INEL/DOE system. Many of the projects conducted by these Science Action Teams were in the areas of environmental restoration and waste management with Foundation and LITCO scientists as mentors. The teams consisted of bright and progressive junior- and senior-high school students and mathematics or science teachers. They performed their research at the INEL over an eight-week period. During 1996, the INEL will host at least 11 Science Action Teams to study either new or follow-on projects from previous years.

By hosting these teams, the INEL supports math, science and research education. Using
INEL facilities and mentors to lead a research activity results in providing useful data to the funding program at a minimal cost. Another benefit is in a future workforce that has been exposed to real world problems and the process required to address those problems. Additionally, most of the end products are of interest to local business communities, federal and state agencies, and universities.

In previous years, the INEL developed partnerships with local universities, cities, school districts, and federal and state agencies. These partners provide resources (supplies, equipment, databases, technical expertise, and time) to support the research. Last year's teams met the following challenges:

- developed an isotope catalog for commercial purposes for a specific test reactor at the INEL

- grew table fish (fish grown for eating) in Lava Hot Springs waste water

- grew the silver scurf fungus on Idaho potatoes to test potential silver scurf eradication techniques for the fungus

- built and demonstrated two table-top robots to validate and demonstrate innovative technologies for remote characterization and remediation of buried waste

- collected and plotted data of southern Idaho ground-water wells on a map to determine how much the water table at various locations had dropped after six to ten years of drought

- studied plant and animal impacts from a major burn in the desert environment

- placed protective boxes on the bottom of an Idaho river bed for the incubation and hatching of salmon eggs. 


\subsection{ENVIRONMENTAL MONITORING}

\section{General}

During normal operation of the facilities at the INEL, some materials (both radioactive and nonradioactive) are released into the environment. Potential pathways by which such materials could be transported from the INEL to nearby populations are shown in Figure 3.1.

To evaluate these exposure pathways, and to verify compliance with applicable environmental protection laws and regulations, DOE Order 5400.1 requires an environmental monitoring program. Environmental monitoring consists of two separate activities: effluent monitoring and environmental surveillance. Effluent monitoring is the measurement of the waste stream prior to its release to the environment. Environmental surveillance is the measurement for the presence or absence and the concentrations (or the extent) of pollutants in the environment. Further defined by the DOE:

- Effluent monitoring is the collection and analysis of samples, or measurements of liquid and gaseous effluents for the purpose of characterizing and quantifying contaminants, assessing radiation exposures of members of the public, providing a means to control effluents at or near the point of discharge, and demonstrating compliance with applicable standards and regulations.

- Environmental surveillance is the collection and analysis of samples, or direct measurements, of air, water, soil, foodstuff, biota, and other media from DOE sites and their environs for the purpose of determining compliance with applicable standards and permit requirements, assessing radiation exposures of members of the public and assessing the effects, if any, on the local environment ${ }^{\mathrm{a}}$.

\section{Organization of Monitoring in 1995}

In 1995, the offsite environmental surveillance program was conducted by the Environmental Science and Research Foundation (Table 3.1), a nonprofit organization. Analyses for the Foundation program were performed primarily by the Idaho State University (ISU) Environmental Monitoring Laboratory, with some radiochemical analyses performed by Quanterra, Inc., an independent commercial laboratory located in Richland, Washington. Nonradiological analyses for the Interagency Monitoring of Protected Visual Environments Program were performed by the Crocker Nuclear Laboratory at the University of California, Davis.

The operating contractors at each INEL facility were responsible for monitoring the effluents (releases) from their facilities and for any ambient monitoring or surveillance performed within their facility fences. Results of these programs are reported annually by each organization. With the consolidation of INEL contractors late in 1994, surveillance programs formerly conducted by Babcock and Wilcox Idaho, EG\&G Idaho, and Westinghouse Idaho Nuclear Company were combined with programs in the new LITCO organization during 1995 (Table 3.2). Most of the analyses for these programs were conducted by the Radiological Measurements Laboratory at TRA and the Radiological and Environmental Measurements Laboratory at

\footnotetext{
- DOE Order 5400.1, November 9, 1988, p. 8.
} 


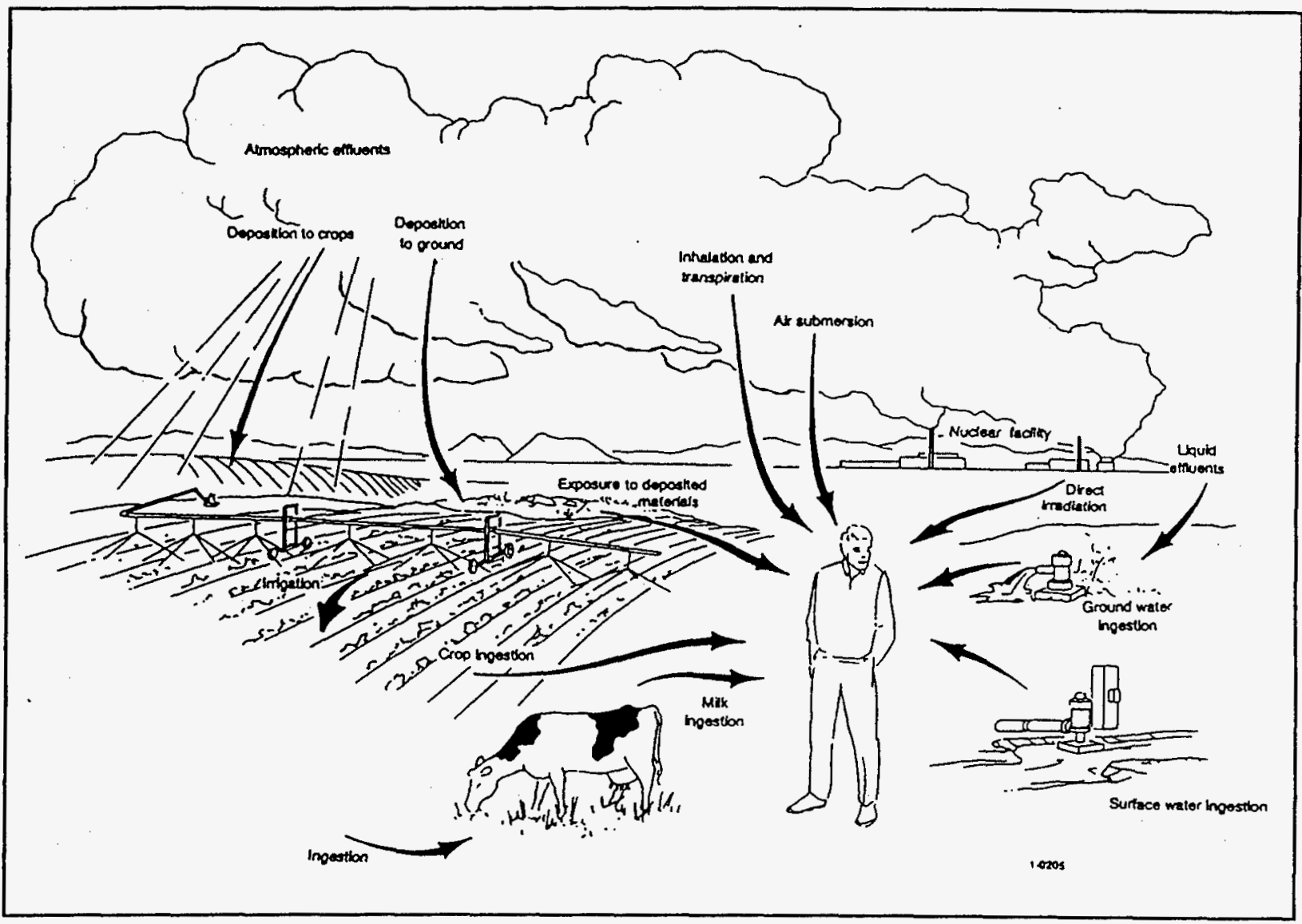

Figure 3.1 Potential Pathways from the INEL to Humans

the INEL Research Center. Radiological analyses for the drinking water program were performed by the DOE-ID Analytical Group at RESL and Accu-Labs Research, Inc., a Colorado commercial laboratory.

Ground-water surveillance was conducted primarily by the USGS. A description of this program and a summary of data collected in 1995 are given in Chapter 5, Ground Water. A USGS program summary is presented in Table 3.3.
Air pathways were characterized by NOAA using data from the INEL meteorological measuring network. These data were used, in part, to compute doses to members of the public (see Section 4.4).

The State of Idaho's INEL Oversight Program took over the independent verification program operated by ISU in 1994. The ISU Environmental Monitoring Laboratory continued to perform radiological analyses for the State program. 
TABLE 3.1

FOUNDATION ENVIRONMENTAL SURVEILLANCE RADIOLOGICAL PROGRAM SUMMARY (1995)

\begin{tabular}{|c|c|c|c|c|}
\hline \multirow[b]{2}{*}{ Medium Sampled } & \multirow[b]{2}{*}{ Type of Analysis } & \multicolumn{2}{|c|}{ Number of Locations and Frequency } & \multirow{2}{*}{$\begin{array}{l}\text {-Minimum Detectable } \\
\text { Concentration }^{\mathbf{a}}\end{array}$} \\
\hline & & Onsite & Offsite & \\
\hline Air (Low-Volume) & $\begin{array}{c}\text { Gross alpha } \\
\text { Gross beta } \\
\text { Specific gamma } \\
\mathrm{Pu} \\
\mathrm{Am} \\
{ }^{90} \mathrm{Sr} \\
\text { Particulate matter } \\
\end{array}$ & $\begin{array}{c}3 \text { weekly } \\
3 \text { weekly } \\
3 \text { quarterly } \\
1-2 \text { quarterly } \\
1-2 \text { quarterly } \\
1-2 \text { quarterly } \\
3 \text { quarterly } \\
\end{array}$ & $\begin{array}{r}11 \text { weekly } \\
11 \text { weekly } \\
11 \text { quarterly } \\
4 \text { quarterly } \\
4 \text { quarterly } \\
4 \text { quarterly } \\
11 \text { quarterly } \\
\end{array}$ & $\begin{array}{c}2 \times 10^{-15} \mu \mathrm{Ci} / \mathrm{mL} \\
5 \times 10^{-15} \mu \mathrm{Ci} / \mathrm{mL} \\
\sim 5 \times 10^{-15} \mu \mathrm{Ci} / \mathrm{mL} \\
7 \times 10^{-18} \mu \mathrm{Ci} / \mathrm{mL} \\
8 \times 10^{-18} \mu \mathrm{Ci} / \mathrm{mL} \\
7 \times 10^{-17} \mu \mathrm{Ci} / \mathrm{mL} \\
10 \mu \mathrm{g} / \mathrm{m}^{3} \\
\end{array}$ \\
\hline Air (Tritium Samplers) & ${ }^{3} \mathrm{H}$ & None & 2 to $4 /$ quarter & $3 \times 10^{-13} \mu \mathrm{Ci} / \mathrm{mL}$ \\
\hline Air (Precipitation) & ${ }^{3} \mathrm{H}$ & 1 weekly/ 1 monthly & 1 monthly & $3 \times 10^{-7} \mu \mathrm{Ci} / \mathrm{mL}$ \\
\hline Drinking Water & $\begin{array}{c}\text { Gross alpha } \\
\text { Gross beta } \\
{ }^{3} \mathrm{H}\end{array}$ & $\begin{array}{l}\text { None } \\
\text { None } \\
\text { None } \\
\end{array}$ & $\begin{array}{l}13 \text { semiannually } \\
13 \text { semiannually } \\
13 \text { semiannually }\end{array}$ & $\begin{array}{l}2 \times 10^{-9} \mu \mathrm{Ci} / \mathrm{mL} \\
3 \times 10^{-9} \mu \mathrm{Ci} / \mathrm{mL} \\
3 \times 10^{-7} \mu \mathrm{Ci} / \mathrm{mL} \\
\end{array}$ \\
\hline Surface Water & $\begin{array}{c}\text { Gross alpha } \\
\text { Gross beta } \\
{ }^{3} \mathrm{H} \\
\end{array}$ & $\begin{array}{l}\text { None } \\
\text { None } \\
\text { None } \\
\end{array}$ & $\begin{array}{l}6 \text { quarterly } \\
6 \text { quarterly } \\
6 \text { quarterly } \\
\end{array}$ & $\begin{array}{l}2 \times 10^{-9} \mu \mathrm{Ci} / \mathrm{mL} \\
3 \times 10^{-9} \mu \mathrm{Ci} / \mathrm{mL} \\
3 \times 10^{-7} \mu \mathrm{Ci} / \mathrm{mL}\end{array}$ \\
\hline Animal Tissue (Sheep) ${ }^{\mathrm{b}}$ & Specific gamma & 4 annually & 2 annually & $7 \times 10^{-9} \mu \mathrm{Ci} / \mathrm{mL}$ \\
\hline Animal Tissue (Game) & Specific gamma & Varies annually $^{c}$ & $-\cdots$ & $7 \times 10^{-9} \mu \mathrm{Ci} / \mathrm{mL}$ \\
\hline Foodstuffs (Milk) & $\begin{array}{c}{ }^{131} \mathrm{I} \\
{ }^{131} \mathrm{I} \\
{ }^{90} \mathrm{Sr} \\
{ }^{3} \mathrm{H} \\
\end{array}$ & $\begin{array}{l}\text { None } \\
\text { None } \\
\text { None } \\
\text { None } \\
\end{array}$ & $\begin{array}{c}1 \text { weekly } \\
10 \text { monthly } \\
10 \text { annually } \\
10 \text { annually } \\
\end{array}$ & $\begin{array}{l}2 \times 10^{-9} \mu \mathrm{Ci} / \mathrm{mL} \\
2 \times 10^{-9} \mu \mathrm{Ci} / \mathrm{mL} \\
5 \times 10^{-10} \mu \mathrm{Ci} / \mathrm{mL} \\
3 \times 10^{-7} \mu \mathrm{Ci} / \mathrm{mL}\end{array}$ \\
\hline Foodstuffs (Wheat) & $\begin{array}{c}\text { Specific gamma } \\
{ }^{90} \mathrm{Sr} \\
\end{array}$ & $\begin{array}{l}\text { None } \\
\text { None } \\
\end{array}$ & $\begin{array}{l}10 \text { annually } \\
10 \text { annually } \\
\end{array}$ & $\begin{array}{c}4 \times 10^{-9} \mu \mathrm{Ci} / \mathrm{g} \\
4 \times 10^{-9} \mu \mathrm{Ci} / \mathrm{g} \\
\end{array}$ \\
\hline Foodstuffs (Lettuce) & $\begin{array}{c}\text { Specific gamma } \\
{ }^{90} \mathrm{Sr} \\
\end{array}$ & $\begin{array}{l}\text { None } \\
\text { None } \\
\end{array}$ & $\begin{array}{l}8 \text { annually } \\
8 \text { annually }\end{array}$ & $\begin{array}{l}2 \times 10^{-7} \mu \mathrm{Ci} / \mathrm{g} \\
8 \times 10^{-8} \mu \mathrm{Ci} / \mathrm{g} \\
\end{array}$ \\
\hline Soil & $\begin{array}{c}\text { Specific gamma } \\
\mathrm{Pu} \\
\mathrm{Am} \\
{ }^{90} \mathrm{Sr} \\
\end{array}$ & $\begin{array}{l}\text { None } \\
\text { None } \\
\text { None } \\
\text { None } \\
\end{array}$ & $\begin{array}{l}12 \text { biennially } \\
12 \text { biennially } \\
12 \text { biennially } \\
12 \text { biennially } \\
\end{array}$ & $\begin{array}{l}4 \times 10^{-8} \mu \mathrm{Ci} / \mathrm{g} \\
2 \times 10^{-9} \mu \mathrm{Ci} / \mathrm{g} \\
3 \times 10^{-9} \mu \mathrm{Ci} / \mathrm{g} \\
9 \times 10^{-8} \mu \mathrm{Ci} / \mathrm{g} \\
\end{array}$ \\
\hline $\begin{array}{l}\text { Direct Radiation } \\
\text { Exposure } \\
\text { (Thermoluminescent } \\
\text { Dosimeters) } \\
\end{array}$ & $\begin{array}{l}\text { Ionizing } \\
\text { Radiation }\end{array}$ & None & 13 semiannually & $5 \mathrm{mR}$ \\
\hline
\end{tabular}


TABLE 3.2

LITCO ENVIRONMENTAL SURVEILLANCE RADIOLOGICAL PROGRAM SUMMARY (1995)

\begin{tabular}{|c|c|c|c|c|}
\hline \multirow[b]{2}{*}{ Medium Sampled } & \multirow[b]{2}{*}{ Type of Analysis } & \multicolumn{2}{|c|}{ Number of Locations and Frequency } & \multirow{2}{*}{$\begin{array}{l}\text { Minimum Detectable } \\
\text { Concentration }^{\mathrm{a}}\end{array}$} \\
\hline & & Onsite & Offsite & \\
\hline Air (Low-Volume) & $\begin{array}{c}\text { Gross alpha } \\
\text { Gross beta } \\
\text { Specific gamma } \\
\mathrm{Pu} \\
\mathrm{Am} \\
{ }^{90} \mathrm{Sr} \\
\text { Particulate matter }\end{array}$ & $\begin{array}{l}12 \text { weekly } \\
12 \text { weekly } \\
12 \text { quarterly } \\
12 \text { quarterly } \\
12 \text { quarterly } \\
12 \text { quarterly } \\
12 \text { quarterly } \\
\end{array}$ & $\begin{array}{l}4 \text { weekly } \\
4 \text { weekly } \\
4 \text { quarterly } \\
4 \text { quarterly } \\
4 \text { quarterly } \\
4 \text { quarterly } \\
4 \text { quarterly }\end{array}$ & $\begin{array}{c}1 \times 10^{-15} \mu \mathrm{Ci} / \mathrm{mL} \\
5 \times 10^{-15} \mu \mathrm{Ci} / \mathrm{mL} \\
1 \text { to } 10 \times 10^{-15} \mu \mathrm{Ci} / \mathrm{mL} \\
2 \times 10^{-18} \mu \mathrm{Ci} / \mathrm{mL} \\
2 \times 10^{-18} \mu \mathrm{Ci} / \mathrm{mL} \\
3.5 \times 10^{-17} \mu \mathrm{Ci} / \mathrm{mL} \\
10 \mu \mathrm{g} / \mathrm{m}^{3}\end{array}$ \\
\hline Air (High-Volume) & $\begin{array}{c}\text { Gross gamma } \\
\text { Specific gamma }\end{array}$ & $\begin{array}{l}2 \text { daily } \\
2 \text { monthly }\end{array}$ & 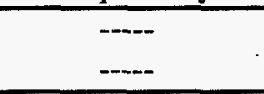 & $\begin{array}{c}\mathrm{N} / \mathrm{A}^{\mathrm{b}} \\
1 \text { to } 10 \times 10^{-16} \mu \mathrm{Ci} / \mathrm{mL}\end{array}$ \\
\hline $\begin{array}{l}\text { Air (Tritium } \\
\text { Samplers) }\end{array}$ & ${ }^{3} \mathrm{H}$ & 2 at 1 to $2 /$ quarter & $-\cdots$ & $1 \times 10^{-11} \mu \mathrm{Ci} / \mathrm{mL}$ \\
\hline Drinking Water & $\begin{array}{c}\text { Gross alpha } \\
\text { Gross beta } \\
{ }^{3} \mathrm{H} \\
{ }^{90} \mathrm{Sr} \\
\end{array}$ & $\begin{array}{r}26 \text { monthly } \\
26 \text { monthly } \\
26 \text { monthly } \\
2 \text { monthly } \\
\end{array}$ & $\begin{array}{l}-\cdots- \\
-\cdots- \\
-\cdots- \\
-\cdots-\end{array}$ & $\begin{array}{l}3 \times 10^{-9} \mu \mathrm{Ci} / \mathrm{mL} \\
4 \times 10^{-9} \mu \mathrm{Ci} / \mathrm{mL} \\
4 \times 10^{-7} \mu \mathrm{Ci} / \mathrm{mL} \\
5 \times 10^{-10} \mu \mathrm{Ci} / \mathrm{mL}\end{array}$ \\
\hline Soil & $\begin{array}{c}\text { Specific gamma } \\
\mathrm{Pu} \\
\mathrm{Am} \\
{ }^{90} \mathrm{Sr} \\
\end{array}$ & $\begin{array}{l}\text { Varies annuallyc }^{c} \\
\text { Varies annually } \\
\text { Varies annually } \\
\text { Varies annually } \\
\end{array}$ & $\begin{array}{l}\cdots-- \\
\cdots-- \\
\cdots-- \\
-\cdots\end{array}$ & $\begin{array}{l}1 \times 10^{-7} \mu \mathrm{Ci} / g \\
3 \times 10^{-9} \mu \mathrm{Ci} / g \\
3 \times 10^{-9} \mu \mathrm{Ci} / g \\
6 \times 10^{-8} \mu \mathrm{Ci} / g \\
\end{array}$ \\
\hline $\begin{array}{l}\text { Direct Radiation } \\
\text { Exposure } \\
\text { (Thermoluminescent } \\
\text { Dosimeters) }\end{array}$ & Ionizing Radiation & 135 semiannually & 13 semiannually & $5 \mathrm{mR}$ \\
\hline $\begin{array}{l}\text { Direct Radiation } \\
\text { Exposure (Radiation } \\
\text { Surveys) }\end{array}$ & Gamma Radiation & $\begin{array}{l}\text { Facilities }^{\mathrm{d}} \\
\text { INEL Roads }^{\mathrm{e}}\end{array}$ & --- & N/A \\
\hline \multicolumn{5}{|c|}{$\begin{array}{l}\text { Approximate minimum detectable concentration. } \\
\text { b Not applicable. } \\
\text { c Onsite soil sampling is performed each year at different onsite facilities on a rotating seven-year schedule. } \\
\text { d Surveys are performed each year at different onsite facilities on a rotating three-year schedule. } \\
\text { e All INEL roadways over which waste is transported are surveyed annually. }\end{array}$} \\
\hline
\end{tabular}


TABLE 3.3

USGS GROUND-WATER MONITORING PROGRAM SUMMARY

\begin{tabular}{|c|c|c|c|c|c|c|}
\hline \multirow{3}{*}{ Constituent } & \multirow{3}{*}{ Frequency } & \multicolumn{2}{|c|}{ Ground Water } & \multicolumn{2}{|c|}{ Surface Water } & \multirow{3}{*}{$\begin{array}{c}\text { - Minimum } \\
\text { Detectable } \\
\text { Concentration }\end{array}$} \\
\hline & & $\begin{array}{r}\text { Number } \\
\text { of Sites }\end{array}$ & $\begin{array}{c}\text { Number of } \\
\text { Samples }\end{array}$ & $\begin{array}{r}\text { Number } \\
\text { of Sites }\end{array}$ & $\begin{array}{c}\text { Number of } \\
\text { Samples }\end{array}$ & \\
\hline & & \multicolumn{4}{|c|}{ Radiological Program } & \\
\hline Gross alpha & Semiannual & 43 & 86 & 4 & 8 & $3 \times 10^{-9}$ \\
\hline Gross beta & Semiannual & 43 & 86 & 4 & 8 & $4 \times 10^{-9}$ \\
\hline \multirow[t]{3}{*}{ Tritium } & Quarterly & 30 & 120 & $\cdots$ & $-\cdots$ & $4 \times 10^{-7}$ \\
\hline & Semiannual & 96 & 192 & 7 & 14 & $4 \times 10^{-7}$ \\
\hline & Annual & 39 & 39 & $\ldots$ & $-\cdots$ & $4 \times 10^{-7}$ \\
\hline \multirow[t]{3}{*}{ Specific gamma } & Quarterly & 6 & 24 & $\ldots$ & 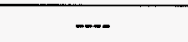 & 1 to $10 \times 10^{-8 b}$ \\
\hline & Semiannual & 54 & 108 & 4 & 8 & 1 to $10 \times 10^{-8}$ \\
\hline & Annual & 27 & 27 & $\ldots$ & $\ldots$ & 1 to $10 \times 10^{-8}$ \\
\hline \multirow[t]{3}{*}{${ }^{90} \mathrm{Sr}$} & Quarterly & 25 & 100 & --- & --- & $5 \times 10^{-9}$ \\
\hline & Semiannual & 60 & 120 & --- & $-\cdots$ & $5 \times 10^{-9}$ \\
\hline & Annual & 32 & 33 & $-\ldots$ & $-\cdots$ & $5 \times 10^{-9}$ \\
\hline \multirow[t]{3}{*}{ Americium } & Quarterly & 5 & 20 & $\overline{---}$ & $\ldots$ & $5 \times 10^{-11}$ \\
\hline & Semiannual & 13 & 26 & - & --- & $5 \times 10^{-11}$ \\
\hline & Annual & 3 & 3 & $\ldots$ & --- & $5 \times 10^{-11}$ \\
\hline \multirow[t]{3}{*}{ Plutonium } & Quarterly & 5 & 20 & $\overline{---}$ & $\ldots$ & $4 \times 10^{-11}$ \\
\hline & Semiannual & 13 & 26 & ---- & --- & $4 \times 10^{-11}$ \\
\hline & Annual & 3 & 3 & $\ldots$ & $\ldots$ & $4 \times 10^{-11}$ \\
\hline${ }^{129} \mathrm{I}$ & -5 years & $20-35$ & $20-35$ & $\cdots$ & ---- & $1 \times 10^{-15}$ \\
\hline \multicolumn{7}{|c|}{ Non-Radiological Program } \\
\hline \multirow[t]{3}{*}{ Conductance } & Quarterly & 30 & 120 & --- & --- & N/A \\
\hline & Semiannual & 96 & 192 & 7 & 14 & N/A \\
\hline & Annual & 39 & 39 & --- & --- & N/A \\
\hline \multirow[t]{3}{*}{ Sodium ion } & Quarterly & 2 & 8 & $-\cdots$ & --- & 0.1 \\
\hline & Semiannual & 45 & 90 & ---- & $\ldots$ & 0.1 \\
\hline & Annual & 99 & 99 & $\ldots$ & --- & 0.1 \\
\hline \multirow[t]{3}{*}{ Chloride ion } & Quarterly & 30 & 120 & ---- & --- & 0.1 \\
\hline & Semiannual & 96 & 192 & 7 & 14 & 0.1 \\
\hline & Annual & 39 & 39 & ---- & $\ldots$ & 0.1 \\
\hline \multirow[t]{2}{*}{ Nitrates (as N) } & Semiannual & 42 & 84 & $m$ & ---- & 0.05 \\
\hline & Annual & 69 & 69 & ---- & --- & 0.05 \\
\hline \multirow[t]{4}{*}{ Sulfate } & Quarterly & 2 & 8 & $\begin{array}{l}--- \\
--\end{array}$ & $\ldots$ & 0.1 \\
\hline & Triannual & 3 & 9 & --- & - & 0.1 \\
\hline & Semiannual & 9 & 18 & --- & $-\cdots$ & 0.1 \\
\hline & Annual & 102 & 102 & --- & $\ldots$ & 0.1 \\
\hline Chromium & Quarterly & 4 & 16 & --- & 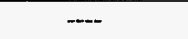 & 0.005 \\
\hline \multirow[t]{2}{*}{ (dissolved) } & Semiannual & 70 & 140 & --- & -- & 0.005 \\
\hline & Annual & 16 & 16 & $\ldots$ & $\ldots$ & 0.005 \\
\hline Purgeable Organic & Monthly & 1 & 12 & $\overline{--}$ & -_- & 0.0002 \\
\hline \multirow[t]{3}{*}{ Compounds ${ }^{c}$} & Quarterly & 4 & 16 & ---- & $\ldots$ & 0.0002 \\
\hline & Semiannual & 17 & 34 & ---- & --- & 0.0002 \\
\hline & Annual & 6 & 6 & $\ldots$ & --- & 0.0002 \\
\hline Trace elements & Annual & 9 & 18 & ---- & --- & varies \\
\hline Minimum detectab & $\begin{array}{l}\text { trations in } \mu \mathrm{C} \\
\text { onuclides pres } \\
61 \text { compounc }\end{array}$ & $\begin{array}{l}\text { r radiolog } \\
\text { le sample }\end{array}$ & eters and $\mathrm{mg}$ & nradiologi & meters. "N/A" & t applicable. \\
\hline
\end{tabular}




\title{
Chapter 4. ENVIRONMENTAL RADIOLOGICAL PROGRAM INFORMATION
}

\begin{abstract}
Chapter Summary
The Environmental Science and Research Foundation and Lockheed Idaho Technologies Company conduct environmental surveillance programs on and around the INEL to monitor potential pathways by which radionuclifes could reach members of the public. These programs collect samples of a varrety of media, including air, water, and foodstuffs such as milk, wheat, lettuce, potatoes, livestock, and game animals. Direct measurements of radiation in the environment are also made. This chapter describes the sampling programs, including the frequency and location of sample collection, and describes the analyses performed on the samples (Section 41 ). For each medium sampled, a summary of the results obtained during 1995 are provided, with tables and graphs used to illustrate trends in these data over the past several years (Section 4.2).

During operations at the ANEL, some radioactive materials are released to the environment in the form of airborne and liquid effluents. The quantities of these materials that were released in 1995 are provided in table form (Section 4.3).

Because the offsite impact of operations at the INEL is generally too small to measure through environmental surveillance, two separate computer models are used to estimate the dose to a member of the public living near the INEL boundary. Results for these two models are described and Compared to DOE and EPA standards for radiation exposure (Section 4.4). This section also provides an evaluation of the potential exposure from consuming game animals such as large game and waterfowl that have resided on the INEL. An estimate is also made of the collective radiation dose to all members of the public who live within $80 \mathrm{~km}$ ( 50 miles) of the central point of the INEL.
\end{abstract}




\section{ENVIRONMENTAL RADIOLOGICAL PROGRAM INFORMATION}

In this chapter, individual analytical results for radiological data are presented with plus or minus $( \pm)$ two analytical standard deviations ( $2 \mathrm{~s})$, where all analytical uncertainties have been estimated, and " $\mathrm{s}$ " is an estimate of the population standard deviation " $\sigma$." Many of the results are less than or equal to $2 \mathrm{~s}$ (and, in fact, some were negative), which means that they are below the minimum detectable concentration.

If a result lies in the range of two to three times its estimated analytical uncertainty ( $2 \mathrm{~s}$ to $3 \mathrm{~s}$ ), and assuming that the result belongs to a Gaussian (normal) distribution, detection of radioactivity by the analysis may be questionable because of statistical variations within the group of samples. If the result exceeds $3 s$, there is confidence that radioactivity was detected (that is, that the specific radionuclide was present in the sample). Further information may be found in Appendix B.

Unpaired, single-tailed t-tests were used to determine whether the annual means for either the INEL or boundary stations were greater than the annual means for the distant stations. The statistical tests used a level of significance of $5 \%(\alpha=0.05)$. More information on statistical tests may be found in Appendix $B$.

\subsection{ENVIRONMENTAL SURVEILLANCE PROGRAM DESCRIPTION}

\section{High-Volume Air Samplers}

LITCO operated two high-volume air samplers at the Experimental Field Station (EFS) and CFA. Both samplers pulled approximately $1,160 \mathrm{~L} / \mathrm{min}\left(50 \mathrm{ft}^{3} / \mathrm{min}\right)$ through a $10-\mathrm{cm}$ (4-in) diameter polyester needled-felt filter. Filters were collected each workday and returned to the laboratory for counting. Data from these samplers provides timely information in the event of an INEL release.

The high-volume sampler filters were counted for $10 \mathrm{~min}$ in a sodium iodide well counter immediately following collection and again after approximately $6 \mathrm{~h}$ and $24 \mathrm{~h}$. At the end of the third count, the net counts/min and $h$ after collection were plotted on graph paper. The resulting decay curve distinguishes between the rapid decay of daughter products of ${ }^{222} \mathrm{Rn}\left({ }^{214} \mathrm{~Pb}\right.$ and $\left.{ }^{214} \mathrm{Bi}\right)$, the approximate $10.6-\mathrm{h}$ effective half-life of ${ }^{220} \mathrm{Rn}$ daughters $\left({ }^{212} \mathrm{~Pb}\right.$,
${ }^{212} \mathrm{Bi}$ and ${ }^{208} \mathrm{Tl}$ ), all of which are naturally-occurring radionuclides, and the generally long half-life (compared to $10.6 \mathrm{~h}$ ) of any fission products mixture. If the graph indicates the possible presence of activity from other than natural sources, the filter can then be submitted for specific gamma-emitting nuclide analysis on a High-Purity Germanium system.

\section{Low-Volume Air Samplers}

Airborne particulate radioactivity was monitored continuously by a network of lowvolume air samplers. The Environmental Science and Research Foundation operated 11 air samplers outside the INEL boundaries, and three samplers on the INEL (Figure 4.1). LITCO collected air at 12 locations onsite and at four offsite locations. Locations of onsite samplers were selected to give adequate coverage in the event of releases of radioactivity from INEL facilities. Seven offsite air sampling locations were near the INEL boundary and four sampling locations were situated at the distant communities of Blackfoot, Idaho Falls, Rexburg, and Craters of the Moon National 


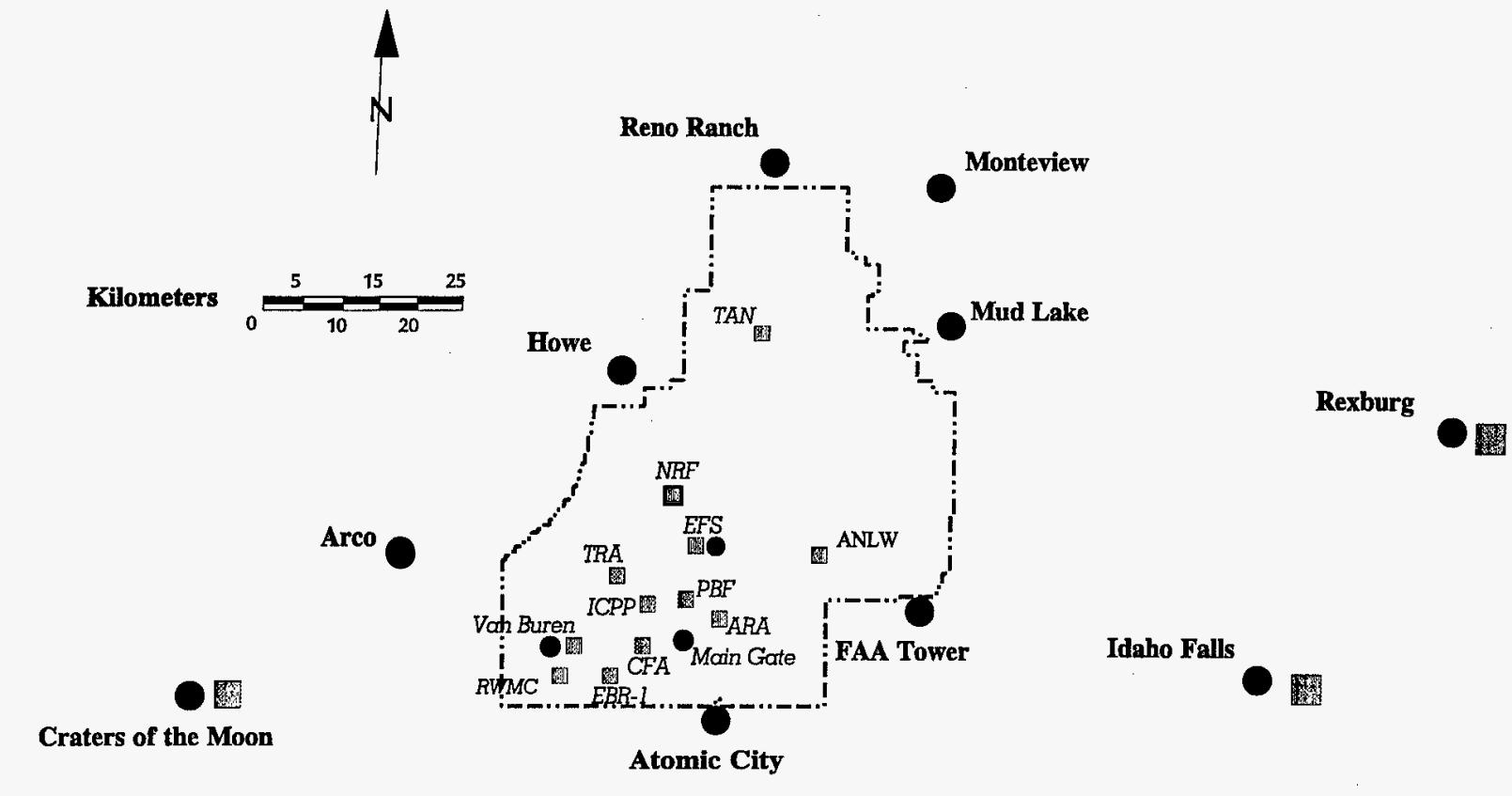

Blackfoot

- Foundation Low-Volume Air Sampler Location

- LITCO Low-Volume Air Sampler Location

Figure 4.1 Low-Volume Air Sampler Locations

Monument. Distant locations were used to provide background measurements for comparison with data from either boundary or onsite samplers that might be affected by INEL operations. The whole network provides comprehensive surveillance of particulate atmospheric radioactivity and makes it possible to differentiate INEL releases from worldwide fallout from nuclear weapons testing and longlived natural radioactivity.

Each low-volume air sampler maintained an average air flow of about $50 \mathrm{~L} / \mathrm{min}$ $\left(2 \mathrm{ft}^{3} / \mathrm{min}\right)$ through a set of filters consisting of a $1.2-\mu \mathrm{m}$ pore membrane filter followed by a charcoal cartridge. The filters are $99 \%$ efficient for airborne particulate radioactivity and airborne iodides.

Weekly Screening Analyses. The particulate filters from the low-volume air samplers were collected and analyzed weekly. The charcoal cartridges from Foundation air samplers were screened for ${ }^{131} \mathrm{I}$ by counting groups of up to eight cartridges by gamma spectrometry. If any activity above a certain level is noted on a batch during screening, filters from the batch can then 
be counted individually. For cartridges collected from samplers operated by LITCO, all the charcoal cartridges were evaluated individually each week for ${ }^{131} \mathrm{I}$ by gamma spectrometry.

Particulate filters were analyzed after waiting a minimum of four days to allow the naturally occurring, short-lived radon and thoron daughters to decay. Analyses for gross (nonspecific) alpha and gross beta activity were performed on filters from all locations each week. A Canberra automatic proportional counting system was used to screen the Foundation's samples; LITCO performed gross counting on a Tennelec proportional counter.

Specific Radionuclide Analyses. Specific radionuclide analyses are more sensitive than gross alpha and gross beta analyses for detecting concentrations of manmade radionuclides in air. Therefore, the membrane filters of the low-volume samplers were composited by location at the end of each quarter, and all composites were analyzed for specific radionuclides by gamma spectrometry. Composites were then submitted for analyses for alphaemitting radionuclides $\left({ }^{238} \mathrm{Pu},{ }^{239 / 240} \mathrm{Pu}\right.$, and ${ }^{241} \mathrm{Am}$ ) or ${ }^{90} \mathrm{Sr}$. LITCO performed each of these analyses on all of their composites. The Foundation analyzed a selected number of their composites for these radionuclides on a rotating schedule. The analyses for alpha-emitting nuclides used chemical separation techniques followed by alpha spectrometry; for ${ }^{90} \mathrm{Sr}$, the chemical separation was followed by beta counting.

\section{Atmospheric Moisture Samplers}

Samplers for tritium in water vapor in the atmosphere were located in Idaho Falls, Atomic City, and at the EFS and Van Buren locations on the INEL. In these samplers, air was passed through a column of silica gel at a rate of approximately $0.3 \mathrm{~L} / \mathrm{min}\left(0.65 \mathrm{ft}^{3} / \mathrm{h}\right)$. Water vapor in the air was absorbed by the gel in the column; columns were changed when the gel had absorbed sufficient moisture to obtain a sample. Tritium concentrations were then determined by liquid scintillation counting of the water extracted from the silica gel columns.

\section{Precipitation Samplers}

Monthly precipitation samples were collected on the INEL at CFA and at the offsite location of Idaho Falls. In addition, weekly samples were collected at EFS when available. A portion of each precipitation sample was submitted for tritium analysis by liquid scintillation counting.

\section{Water Sampling Program}

Onsite drinking water samples were collected monthly from production wells in use at active INEL facilities from January through June by the contractor responsible for each facility. Duplicate water samples were collected quarterly at some locations and analyzed by a separate offsite analytical laboratory for comparison purposes. After June, a quarterly sampling schedule was adopted, except at NRF where sampling continued on a monthly basis. The Environmental Science and Research Foundation collected semiannual drinking water samples from boundary and distant communities, and surface water samples from the Snake River at Idaho Falls and Bliss. In addition, quarterly drinking water and surface water samples were collected from the Magic Valley area (Figure 4.2). Each Magic Valley sample was collected simultaneously with the State of Idaho Oversight Program for 
comparison to their independent environmental surveillance program. The Foundation's data are compared to the State's data for these water samples in Chapter 7, "Quality Assurance."

In addition to production well monitoring, the USGS conducted an extensive ground-water surveillance program on the INEL. A description of the USGS portion of the water surveillance program and maps showing locations of their sampling wells are included in Chapter 5, "Ground Water."

Water Sample Analyses. Each water sample collected by the Foundation and LITCO was submitted for gross analyses for alpha and beta-emitting radionuclides. For gross alpha analysis, a portion of the sample was evaporated on a stainless steel planchet and counted with a scintillation counter system. For determination of gross beta activity, a portion of the sample was evaporated and counted in a lowbackground beta counter. The minimum detectable concentrations for gross alpha and gross beta were approximately $3 \times 10^{-9}$ and $4 \times 10^{-9} \mu \mathrm{Ci} / \mathrm{mL}$, respectively, or about $10 \%$ and $4 \%$ of the DOE derived concentration guides for radiation protection of the public (see Appendix A). These minimum detectable concentrations are also $20 \%$ and $8 \%$, respectively, of maximum contaminant levels established by the EPA for gross alpha and gross beta in public drinking water systems.

Tritium analyses were performed on all of the drinking and surface water samples collected. Concentrations of tritium were determined by using a liquid scintillation counter.

Strontium-90 analyses were performed on samples from drinking water wells in the ICPP area because the water quality at these wells has periodically been affected by the ${ }^{90} \mathrm{Sr}$ waste plume as determined by the USGS. Samples from wells at other facilities were analyzed for
${ }^{90} \mathrm{Sr}$ once during the year. Strontium-90 was separated from the sample chemically and, after an ingrowth period, its ${ }^{90} \mathrm{Y}$ decay product was separated chemically and counted in a lowbackground beta counter to determine the amount of ${ }^{90} \mathrm{Sr}$ initially present in the sample. The minimum detectable concentrations for tritium and ${ }^{90} \mathrm{Sr}$ are $4 \times 10^{-7}$ and $5 \times 10^{-10}$ $\mu \mathrm{Ci} / \mathrm{mL}$, or about $0.02 \%$ and $0.05 \%$, respectively, of the DOE derived concentration guides for radiation protection of the public. These minimum detectable concentrations are about $2 \%$ and $6 \%$, respectively, of maximum contaminant levels for community drinking water listed by the EPA in 1995.

\section{Foodstuff Sampling Program}

Samples of milk, wheat, potatoes, and leafy garden lettuce from locations near the INEL boundary and at distant locations were collected (Figure 4.2). Tissues were also obtained from sheep that grazed on the INEL, large game animals that were accidentally killed on NEL roads, and fish from the Big Lost River. Waterfowl from waste disposal ponds at some facilities were also collected in 1995 . Wheat, potatoes, and lettuce were chosen for sampling because they are part of the typical American diet or are major agricultural products of the region. Each represents a potential pathway to the public for radionuclides from fallout and from INEL operations. Game animals represent a potential pathway to members of the public who might consume animals that have foraged on the INEL.

Milk. Milk samples were collected from both commercial and single-family dairies. A 4-L (1-gal) sample was obtained from each location monthly, except in Idaho Falls where a sample was collected weekly. Milk from each location 
Chapter 4: Environmental Radiological Program Information

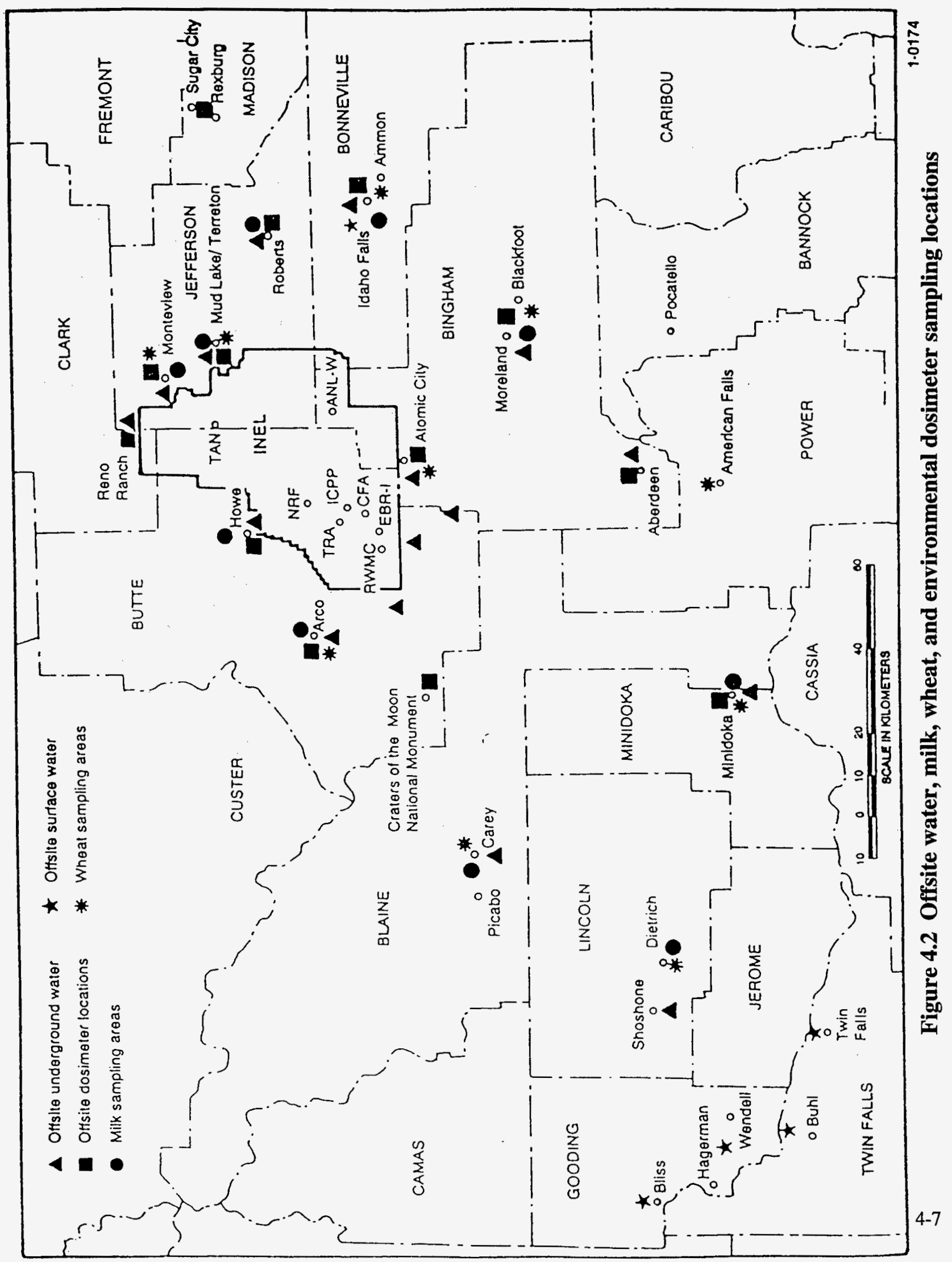


was analyzed for ${ }^{131} \mathrm{I}$, and one analysis for ${ }^{90} \mathrm{Sr}$ and tritium at each location was performed during the year.

Lettuce. Lettuce samples were obtained from private gardens in communities in the vicinity of the INEL. Samples were washed to remove any soil as in normal food preparation, dried, reduced to a powdered form, and weighed. All lettuce samples were analyzed for ${ }^{90} \mathrm{Sr}$ and gamma-emitting radionuclides.

Wheat. Wheat samples were collected from grain elevators in the region surrounding the INEL. A portion of each sample was placed in a plastic container and weighed. All wheat samples were analyzed for ${ }^{90} \mathrm{Sr}$ and gammaemitting radionuclides.

Potatoes. Potato samples were collected from storage warehouses in the INEL vicinity. The samples, with cleaned skins included, were processed and weighed. All potato samples were analyzed for ${ }^{90} \mathrm{Sr}$ and gamma-emitting radionuclides.

Sheep. Samples of tissue (muscle, liver, and thyroid) were collected from sheep grazing on the INEL. Control samples were collected from Blackfoot. The muscle and liver were processed and analyzed by gamma spectrometry. The thyroid was placed in a vial and analyzed specifically for ${ }^{131} \mathrm{I}$.

Game Animals. Selected tissues (muscle, liver, and thyroid) were collected from game animals accidentally killed on INEL roads. Thyroid samples were placed in vials and analyzed by gamma spectrometry specifically for ${ }^{131} \mathrm{I}$. Muscle and liver samples were processed, placed in a plastic container, and weighed prior to gamma spectrometry.
Fish were obtained from the Big Lost River, which flowed onto the INEL during late spring and early summer of 1995 . Fish samples were analyzed for gamma-emitting radionuclides.

Samples were collected of waterfowl using waste disposal ponds at four facilities on the INEL as part of a cooperative effort between the Foundation's environmental surveillance and ecological research programs. Waterfowl samples were separated into an external portion (consisting of the skin and feathers), edible portion (muscle tissue), and remainder portion. All samples were analyzed by gamma spectrometry. Selected samples were also analyzed for ${ }^{90} \mathrm{Sr}$ and transuranic radionucides.

\section{Environmental Dosimeters}

Environmental dosimeters, known as thermoluminescent dosimeters (TLDs), were used to measure ionizing radiation exposures (beta energies greater than $200 \mathrm{keV}$ and gamma energies greater than $10 \mathrm{keV}$ ). The TLDs measure ionizing radiation exposures from natural radioactivity in the air and soil, cosmic radiation from space, fallout from nuclear weapons tests, radioactivity from fossil fuel burning, and radioactive effluents from INEL operations and other industrial processes.

At each location, a dosimeter card containing five individual chips was placed $1 \mathrm{~m}$ ( $3 \mathrm{ft}$ ) above ground level. The dosimeter card at each location was changed semiannually. There were seven distant community locations, six boundary locations, and 135 locations on the INEL with environmental dosimeters. 


\subsection{ENVIRONMENTAL SURVEILLANCE PROGRAM RESULTS}

\section{High-Volume Samplers}

The two onsite high-volume air monitors (located at CFA and EFS) continuously sampled the air for particulate airborne radioactivity. All decay curves appeared normal and no special analyses were conducted on daily filters during 1995.

Beryllium-7, a naturally-occurring radionuclide produced by the interaction of cosmic radiation and nitrogen in the atmosphere, was detected on all of the monthly composites. Several manmade radionuclides $\left({ }^{22} \mathrm{Na},{ }^{58} \mathrm{Co},{ }^{95} \mathrm{Nb},{ }^{103} \mathrm{Ru},{ }^{106} \mathrm{Ru},{ }^{110} \mathrm{Ag},{ }^{141} \mathrm{Ce}\right.$, ${ }^{154} \mathrm{Eu}$, and ${ }^{181} \mathrm{Hf}$ ) were found on one onsite monthly composite each but all were near the minimum detectable concentration. In addition, one radionuclide, ${ }^{134} \mathrm{Cs}$, was found with a concentration above the questionable detection range on the March composite from EFS onsite. The concentration of $(5.6 \pm 1.8) \times 10^{-16} \mu \mathrm{Ci} / \mathrm{ml}$ was $0.003 \%$ of the derived concentration guide.

\section{Low-Volume Charcoal Cartridges}

LITCO analyzed a total of 784 cartridges specifically for ${ }^{131} \mathrm{I}$. This radionuclide was found near the minimum detectable concentration on three cartridges. The highest ${ }^{131} \mathrm{I}$ concentration of $(1.5 \pm 1.4) \times 10^{-14} \mu \mathrm{Ci} / \mathrm{ml}$, at TAN during the week of May 17 to May 24, was $0.004 \%$ of the derived concentration guide.

Four sets of weekly cartridges from the Foundation samplers contained ${ }^{131} \mathrm{I}$ that was above the minimum detectable concentration, but none of the batches were above the action level in place during 1995 that required the filters to be counted individually. For 1996, the action level was lowered to require individual counting of sets with any detectable activity. The highest ${ }^{131} \mathrm{I}$ concentration found in 1995, assuming that the maximum batch concentration was all contained in one filter, was $(9 \pm 7) \times 10^{-15} \mu \mathrm{Ci} / \mathrm{ml}$, or $0.002 \%$ of the derived concentration guide.

\section{Low-Volume Gross Alpha}

Gross alpha concentrations obtained by LITCO, both onsite and offsite, were significantly lower than those obtained by the Foundation at common locations (Table 4.1). This discrepancy is likely due to differences in laboratory analytical techniques and instrumentation. Both sets of data indicated, however, that gross alpha concentrations were generally higher at distant locations than at boundary and onsite locations. There were no locations with gross alpha concentrations that were statistically greater than the background group mean gross alpha concentration.

\section{Low-Volume Gross Beta}

Analysis of gross beta concentrations in air samples collected by the Foundation and those collected by LITCO at common locations indicated that the Foundation results were, in general, statistically higher. See Chapter 7 for a comparison table of gross beta concentrations. This difference is probably a result of differences in the analytical methods and instrumentation used in the counting of the filters. Due to this statistical difference, direct comparisons of gross beta concentrations were made only within sets of data collected by a single organization. Weekly gross beta concentrations in air samples collected by the Foundation ranged from a low of $(-4 \pm 3) \times 10^{-15}$ 
TABLE 4.1

GROSS ALPHA ACTIVITY IN AIR (1995)

\begin{tabular}{|c|c|c|c|c|}
\hline \multicolumn{5}{|c|}{ Environmental Science and Research Foundation Data } \\
\hline \multirow{3}{*}{$\frac{\text { Group }}{\text { Distant }}$} & \multirow[b]{2}{*}{ Location } & \multirow[b]{2}{*}{$\begin{array}{c}\text { Number of } \\
\text { Samples }\end{array}$} & \multicolumn{2}{|c|}{ Concentration $\left(\times 10^{-15} \mu \mathrm{Ci} / \mathrm{mL}\right)$} \\
\hline & & & $\begin{array}{l}\text { Range of } \\
\text { Samples } \\
\end{array}$ & $\begin{array}{c}\text { Annual } \\
\text { Mean }^{\mathrm{a}}\end{array}$ \\
\hline & Blackfoot & 52 & $-0.1-3.8$ & $1.6 \pm 0.3$ \\
\hline & Craters of the Moon & 51 & $-0.9-3.3$ & $1.0 \pm 0.3$ \\
\hline & Idaho Falls & 52 & $-0.5-3.3$ & $1.5 \pm 0.3$ \\
\hline & Rexburg & 52 & $-0.4-4.2$ & $1.7 \pm 0.3$ \\
\hline & & & Grand Mean ${ }^{a}$ & $1.4 \pm 0.1$ \\
\hline \multirow[t]{8}{*}{ Boundary } & Arco & 52 & $-0.2-2.5$ & $1.1 \pm 0.2$ \\
\hline & Atomic City & 51 & $-0.3-4.5$ & $1.3 \pm 0.3$ \\
\hline & FAA Tower & 52 & $-0.1-3.2$ & $1.3 \pm 0.2$ \\
\hline & Howe & 52 & $-0.3-3.7$ & $1.2 \pm 0.2$ \\
\hline & Monteview & 52 & $-0.6-4.2$ & $1.4 \pm 0.3$ \\
\hline & Mud Lake & 52 & $-0.4-3.8$ & $1.0 \pm 0.3$ \\
\hline & Reno Ranch & 51 & $-2.9-3.2$ & $1.2 \pm 0.3$ \\
\hline & & & Grand Mean ${ }^{a}$ & $1.2 \pm 0.1$ \\
\hline \multirow[t]{4}{*}{ INEL } & EFS & 52 & $-0.6-3.1$ & $1.1 \pm 0.2$ \\
\hline & Main Gate & 50 & $-0.5-3.0$ & $1.2 \pm 0.2$ \\
\hline & Van Buren & 52 & $-0.7-3.9$ & $1.3 \pm 0.3$ \\
\hline & & & Grand Mean ${ }^{a}$ & $1.2 \pm 0.1$ \\
\hline \multicolumn{5}{|c|}{ LITCO Data } \\
\hline \multirow{7}{*}{$\frac{\text { Group }}{\text { Distant }}$} & & & \multicolumn{2}{|c|}{ Concentration $\left(\times 10^{-15} \mu \mathrm{Ci} / \mathrm{mL}\right)$} \\
\hline & Location & $\begin{array}{c}\text { Number of } \\
\text { Samples }\end{array}$ & $\begin{array}{l}\text { Range of } \\
\text { Samples } \\
\end{array}$ & $\begin{array}{c}\text { Annual } \\
\text { Mean }^{\mathrm{a}}\end{array}$ \\
\hline & Blackfoot & 47 & $-2.0-3.3$ & $0.8 \pm 0.4$ \\
\hline & Craters of the Moon & 52 & $-0.8-2.2$ & $0.6 \pm 0.2$ \\
\hline & Idaho Falls & 48 & $-1.0-2.1$ & $0.8 \pm 0.2$ \\
\hline & Rexburg & 51 & $-0.6-5.3$ & $1.3 \pm 0.3$ \\
\hline & & & Grand Mean $^{a}$ & $0.9 \pm 0.1$ \\
\hline \multirow[t]{13}{*}{ INEL } & ANL-W & 48 & $-1.1-2.1$ & $0.5 \pm 0.2$ \\
\hline & ARA & 52 & $-1.0-2.6$ & $0.7 \pm 0.2$ \\
\hline & CFA & 49 & $-1.6-3.2$ & $0.6 \pm 0.3$ \\
\hline & EBR-1 & 52 & $-1.2-3.0$ & $0.6 \pm 0.2$ \\
\hline & EFS & 50 & $-0.8-2.3$ & $0.6 \pm 0.2$ \\
\hline & ICPP & 52 & $-0.9-2.7$ & $0.5 \pm 0.2$ \\
\hline & NRF & 45 & $-3.0-3.1$ & $0.7 \pm 0.3$ \\
\hline & PBF & 51 & $-1.7-3.4$ & $0.7 \pm 0.4$ \\
\hline & RWMC & 51 & $-0.8-2.3$ & $0.6 \pm 0.2$ \\
\hline & TAN & 52 & $-0.6-2.3$ & $0.7 \pm 0.2$ \\
\hline & TRA & 48 & $-0.5-2.3$ & $0.6 \pm 0.2$ \\
\hline & Van Buren & 52 & $-1.3-2.6$ & $\underline{0.8 \pm 0.3}$ \\
\hline & & & Grand Mean ${ }^{a}$ & $0.6 \pm 0.1$ \\
\hline
\end{tabular}


$\mu \mathrm{Ci} / \mathrm{mL}$ at Idaho Falls during the month of June to a high of $(81 \pm 9) \times 10^{-15} \mu \mathrm{Ci} / \mathrm{mL}$ at the Main Gate during August. LITCO results ranged from $(3 \pm 2) \times 10^{-15} \mu \mathrm{Ci} / \mathrm{mL}$ at TRA during the month of May to $(61 \pm 4) \times 10^{-15} \mu \mathrm{Ci} / \mathrm{mL}$ at EFS during December. Figure 4.3 indicates the average weekly gross beta concentrations for the INEL, boundary, and distant station groups. These data are typical of the annual pattern for gross beta concentrations in air, with higher values generally occurring at the beginning and end of the calendar year during wintertime inversion conditions, with the exception of the peak shown in the Foundation data in late August. No specific cause for this peak was found, but all sample locations, including the background locations, showed an increase during this week.

Monthly gross beta concentrations for the distant, boundary, and INEL groups are shown in Figure 4.4. Gross beta concentrations peaked dramatically after the Chernobyl accident in April 1986. The distant location vs. INEL graph also shows the effects of ${ }^{125} \mathrm{Sb}$ releases from the Fluorinel Dissolution and Fuel Storage Facility at ICPP during late-1986 to mid-1988.

Foundation annual mean gross beta concentrations ranged from $23 \times 10^{-15} \mu \mathrm{Ci} / \mathrm{mL}$ at Arco and Mud Lake to $28 \times 10^{-15} \mu \mathrm{Ci} / \mathrm{mL}$ at EFS and the Main Gate (Table 4.2). LITCO data indicated a range of $17 \times 10^{-15} \mu \mathrm{Ci} / \mathrm{mL}$ at RWMC to $23 \times 10^{-15} \mu \mathrm{Ci} / \mathrm{mL}$ at PBF. The maximum concentration found was $0.9 \%$ of the annual derived concentration guide for gross beta.

\section{Statistical Comparisons. Statistical} comparisons were made between monthly mean gross beta concentrations at each individual onsite and boundary location and the distant group mean gross beta concentration. Foundation data indicated statistical differences in one of $36(3 \%)$ comparisons involving INEL locations and four of $84(5 \%)$ comparisons involving boundary locations (Table 4.3). For LITCO samplers, statistical differences were found in 16 of 144 (11\%) comparisons made for the INEL locations. Comparisons were also made between the mean gross beta concentration of the boundary group (or onsite group) and the distant group mean gross beta concentration. For Foundation data, the boundary group was not found to be statistically higher during any month, and the INEL group only during October. The INEL group gross beta concentration obtained by LITCO was not statistically greater than background during any month of the year.

Statistical comparisons were made between annual gross beta mean concentrations at individual onsite and boundary locations and the mean background gross beta concentration (Table 4.3). No statistical differences were found in the Foundation data. For 1995, the gross beta concentration at EBR-1, PBF, and TRA were statistically greater than the distant gross beta concentration among the LITCO sampling locations. Neither the boundary group as a whole nor the INEL group as a whole were statistically greater than background.

Gross beta concentrations can vary widely from location to location as a result of a number of factors such as diverse local soil and meteorological conditions. When statistical differences are found, the results of specific nuclide analyses (discussed in the following section) are examined to try to pinpoint a possible INEL cause for the differences.

\section{Low-Volume Specific Radionuclides}

Besides ${ }^{7} \mathrm{Be}$, which is naturally-occurring and appears in nearly all the quarterly composites analyzed, several other manmade 


\section{Weekly Gross Beta Concentrations in Air}
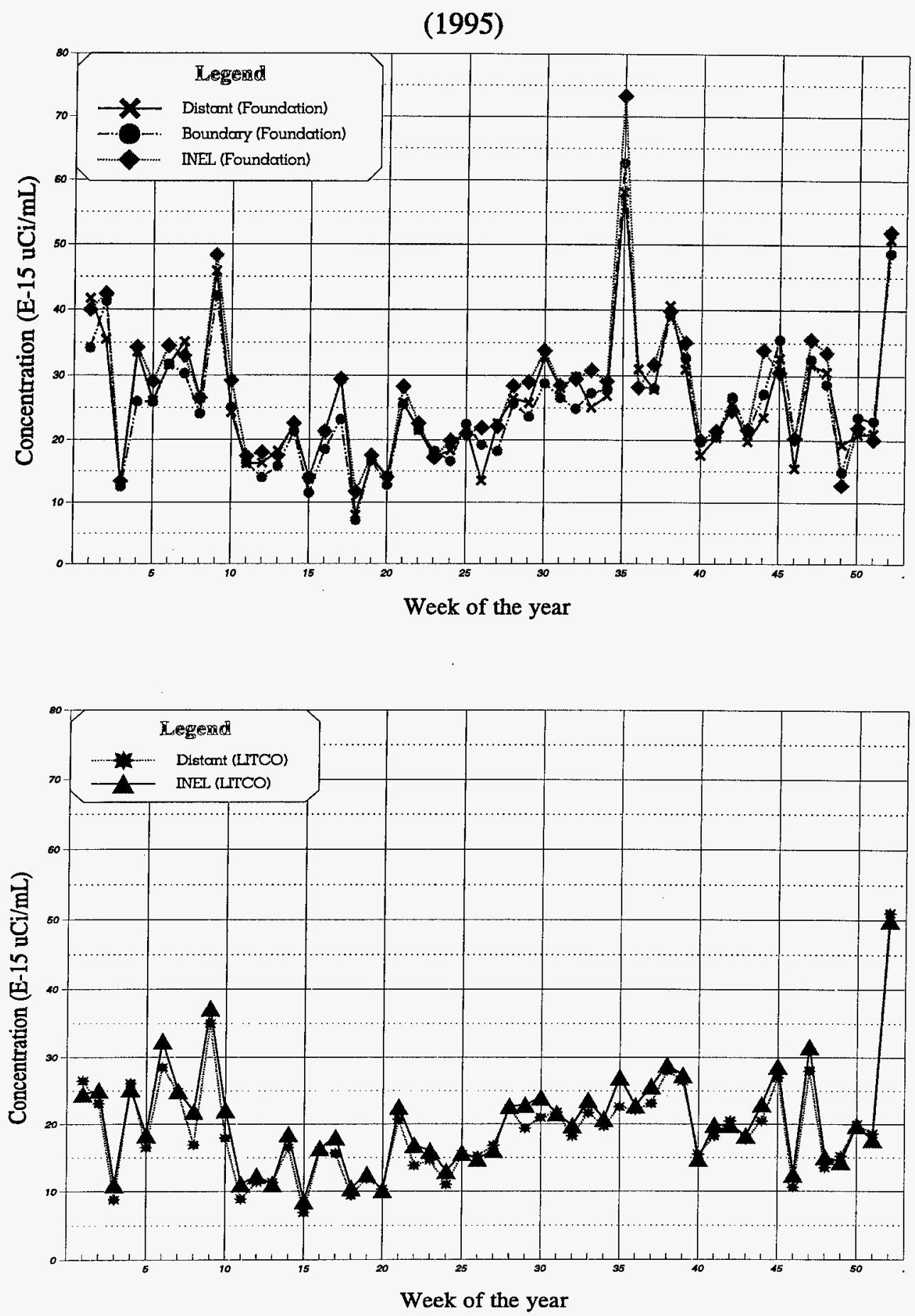

Figure 4.3 Weekly Gross Beta Concentrations in Air (1995) 
Distant vs. Boundary Gross Beta

Concentrations (1986-1990)

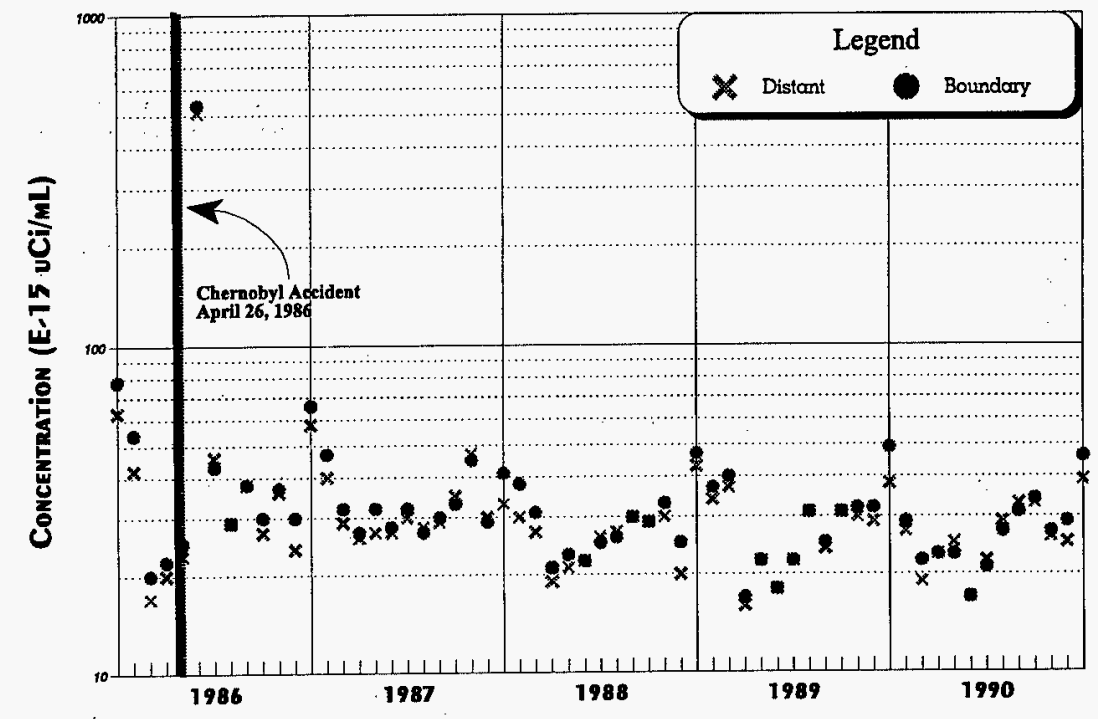

Distant vs. INEL Gross Beta

Concentrations (1986-1990)

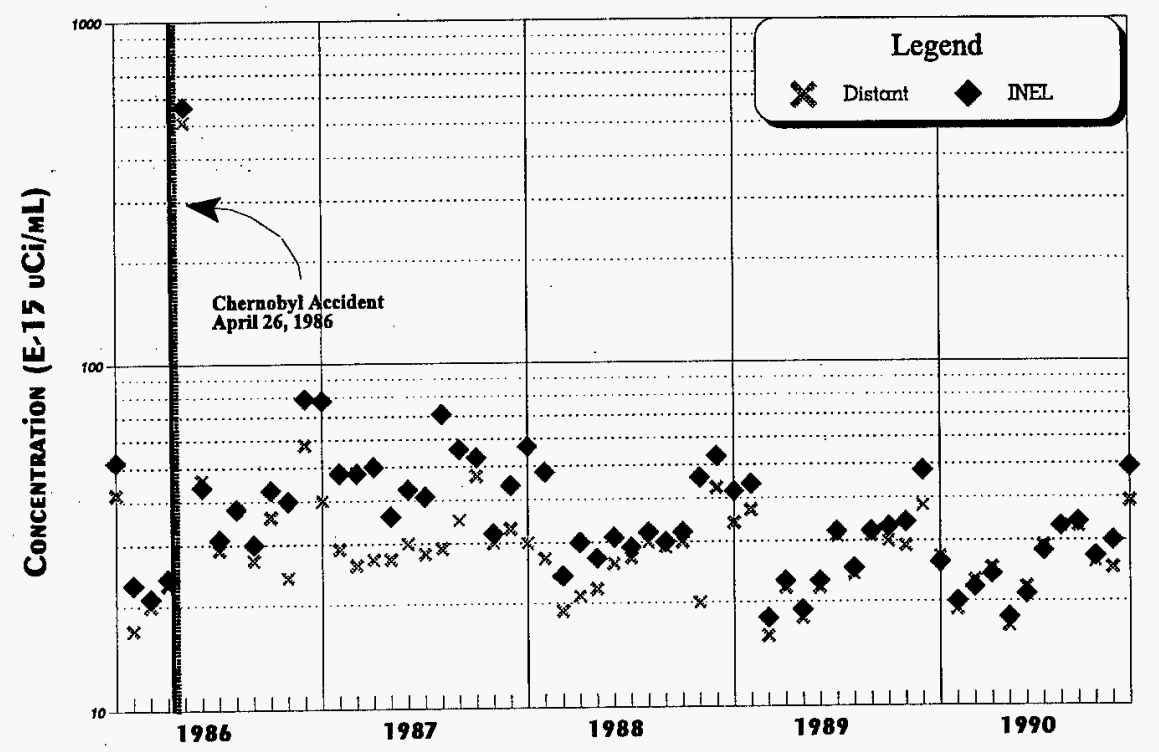

Figure 4.4 Monthly Gross Beta Concentrations (1986-1990) 
Distant vs. Boundary Gross Beta

Concentrations (1991-1995)

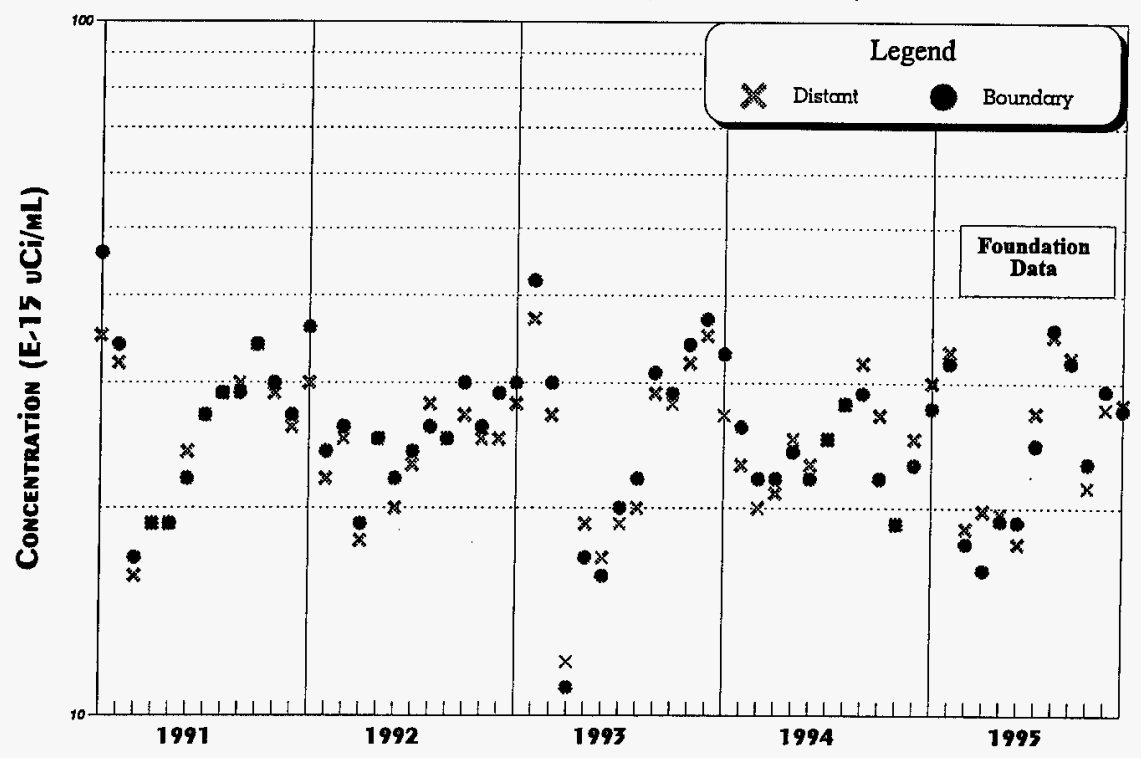

Distant vs. INEL Gross Beta

Concentrations (1991-1995)

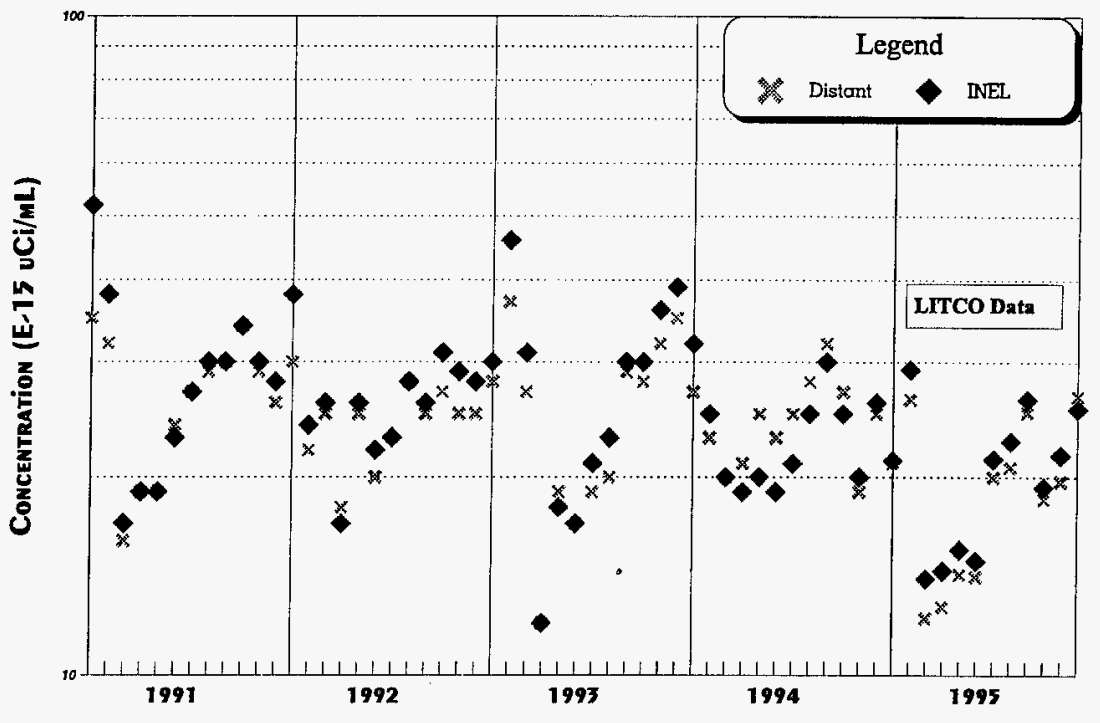

Figure 4.4 (Continued) Monthly Gross Beta Concentrations (1991-1995) 
Chapter 4: Environmental Radiological Program Information

TABLE 4.2

GROSS BETA ACTIVITY IN AIR (1995)

\section{Environmental Science and Research Foundation Data}

\begin{tabular}{|c|c|c|c|c|}
\hline \multicolumn{5}{|c|}{ 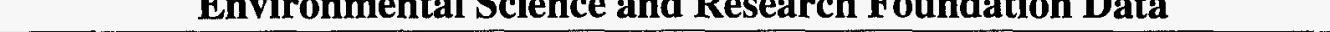 } \\
\hline & \multirow[b]{2}{*}{ Location } & \multirow[b]{2}{*}{$\begin{array}{c}\text { Number of } \\
\text { Samples }\end{array}$} & \multicolumn{2}{|c|}{ Concentration $\left(\times 10^{-15} \mu \mathrm{Ci} / \mathrm{mL}\right)$} \\
\hline & & & $\begin{array}{l}\text { Range of } \\
\text { Samples } \\
\end{array}$ & $\begin{array}{c}\text { Annual } \\
\text { Mean }^{\mathrm{a}}\end{array}$ \\
\hline & Blackfoot & 52 & $10-72$ & $\overline{27 \pm 3}$ \\
\hline \multirow{4}{*}{ Distant } & Craters of the Moon & 51 & $2-46$ & $26 \pm 3$ \\
\hline & Idaho Falls & 52 & $-4-63$ & $25 \pm 4$ \\
\hline & Rexburg & 52 & $11-61$ & $\underline{25 \pm 3}$ \\
\hline & & & Grand Mean ${ }^{a}$ & $26 \pm 1$ \\
\hline \multirow[t]{8}{*}{ Boundary } & Arco & 52 & $-1-67$ & $23 \pm 3$ \\
\hline & Atomic City & 51 & $11-69$ & $27 \pm 3$ \\
\hline & FAA Tower & 52 & $6-67$ & $25 \pm 3$ \\
\hline & Howe & 52 & $10-49$ & $26 \pm 3$ \\
\hline & Monteview & 52 & $11-70$ & $27 \pm 3$ \\
\hline & Mud Lake & 52 & $0-67$ & $23 \pm 4$ \\
\hline & Reno Ranch & 51 & $0-73$ & $\underline{26 \pm 3}$ \\
\hline & & & Grand Mean ${ }^{a}$ & $\overline{25 \pm 1}$ \\
\hline \multirow[t]{4}{*}{ INEL } & EFS & 52 & $10-66$ & $28 \pm 3$ \\
\hline & Main Gate & 50 & $8-81$ & $28 \pm 4$ \\
\hline & Van Buren & 52 & $12-73$ & $\underline{27 \pm 3}$ \\
\hline & & & Grand Mean & $28 \pm 1$ \\
\hline \multicolumn{5}{|c|}{ LITCO Data } \\
\hline \multirow{7}{*}{$\frac{\text { Group }}{\text { Distant }}$} & & & \multicolumn{2}{|c|}{ Concentration $\left(\times 10^{-15} \mu \mathrm{Ci} / \mathrm{mL}\right)$} \\
\hline & Location & $\begin{array}{c}\text { Number of } \\
\text { Samples } \\
\end{array}$ & $\begin{array}{l}\text { Range of } \\
\text { Samples } \\
\end{array}$ & $\begin{array}{c}\text { Annual } \\
\text { Mean }^{2}\end{array}$ \\
\hline & Blackfoot & 47 & $7-57$ & $22 \pm 3$ \\
\hline & Craters of the Moon & 52 & $5-37$ & $18 \pm 2$ \\
\hline & Idaho Falls & 48 & $7-58$ & $19 \pm 2$ \\
\hline & Rexburg & 51 & $7-52$ & $18 \pm 2$ \\
\hline & & & Grand Mean ${ }^{a}$ & $19 \pm 1$ \\
\hline \multirow[t]{13}{*}{ INEL } & ANL-W & 49 & $8-45$ & $18 \pm 2$ \\
\hline & ARA & 52 & $8-51$ & $19 \pm 2$ \\
\hline & CFA & 49 & $6-52$ & $20 \pm 3$ \\
\hline & EBR-1 & 52 & $8-53$ & $22 \pm 2$ \\
\hline & EFS & 49 & $5-61$ & $20 \pm 3$ \\
\hline & ICPP & 52 & $7-51$ & $20 \pm 2$ \\
\hline & NRF & 45 & $8-54$ & $21 \pm 3$ \\
\hline & PBF & 51 & $9-59$ & $23 \pm 3$ \\
\hline & RWMC & 51 & $7-30$ & $17 \pm 3$ \\
\hline & TAN & 52 & $9-51$ & $21 \pm 2$ \\
\hline & TRA & 48 & $3-44$ & $22 \pm 2$ \\
\hline & Van Buren & 52 & $10-53$ & $\underline{21 \pm 2}$ \\
\hline & & & Grand Mean ${ }^{a}$ & $20 \pm 1$ \\
\hline
\end{tabular}




\begin{tabular}{|c|c|c|c|c|c|c|c|c|c|c|c|c|c|}
\hline \multicolumn{14}{|c|}{$\begin{array}{c}\text { TABLE } 4.3 \\
\text { STATISTICAL COMPARISON TABLE OF GROSS BETA CONCENTRATIONS } \\
\text { IN AIR AT DISTANT, BOUNDARY, AND INEL LOCATIONS (1995) }\end{array}$} \\
\hline \multicolumn{14}{|c|}{ Environmental Science and Research Foundation Data } \\
\hline Location & Jan & Feb & Mar & Apr & May & Jun & Jul & Aug & Sep & Oct & Nov & Dec & Year \\
\hline \multicolumn{14}{|l|}{ Arco } \\
\hline \multicolumn{14}{|l|}{ Atomic City } \\
\hline \multicolumn{14}{|l|}{ FAA Tower } \\
\hline \multicolumn{14}{|l|}{ Monteview } \\
\hline \multicolumn{14}{|l|}{ Mud Lake } \\
\hline \multicolumn{14}{|l|}{ Reno Ranch } \\
\hline \multicolumn{14}{|l|}{ Boundary Group } \\
\hline \multicolumn{14}{|l|}{ EFS } \\
\hline \multicolumn{14}{|l|}{ Main Gate } \\
\hline \multicolumn{14}{|l|}{ Van Buren } \\
\hline \multirow{2}{*}{\multicolumn{14}{|c|}{ INEL Group }} \\
\hline & & & & & & & & & & & & & \\
\hline Location & Jan & Feb & Mar & Apr & May & Jun & Jul & Aug & Sep & Oct & Nov & Dec & Year \\
\hline \multicolumn{14}{|l|}{ ANL-W } \\
\hline \multicolumn{14}{|l|}{ ARA } \\
\hline \multicolumn{14}{|l|}{ CFA } \\
\hline \multicolumn{14}{|l|}{ EBR-1 } \\
\hline \multicolumn{14}{|l|}{ EFS } \\
\hline \multicolumn{14}{|l|}{ ICPP } \\
\hline \multicolumn{14}{|l|}{ NRF } \\
\hline \multicolumn{14}{|l|}{ PBF } \\
\hline \multicolumn{14}{|l|}{ RWMC } \\
\hline \multicolumn{14}{|l|}{ TAN } \\
\hline \multicolumn{14}{|l|}{ TRA } \\
\hline \multicolumn{14}{|l|}{ Van Buren } \\
\hline \multicolumn{14}{|l|}{ INEL Group } \\
\hline $\begin{array}{l}\text { A black block in } \\
\text { gross beta conce } \\
(\alpha=0.05)\end{array}$ & atri & & & & & & & & & & & & \\
\hline
\end{tabular}

radionuclides were observed in both Foundation and LITCO data (Tables 4.4 and 4.5). Many results were just above the minimum detectable concentration, appeared throughout the year, and occurred at distant as well as onsite locations. It is possible that INEL releases may have been the source of at least some of the detectable radioactivity, but no specific sources could be identified.

Airborne suspension of slightly contaminated soil by construction activities at RWMC is likely the origin of the ${ }^{239 / 240} \mathrm{Pu}$ and ${ }^{241} \mathrm{Am}$ found at RWMC in the second through fourth quarters, and possibly the ${ }^{239 / 240} \mathrm{Pu}$ at 
Chapter 4: Environmental Radiological Program Information

EBR-1 in the second and third quarters. The ${ }^{90} \mathrm{Sr}$ found at ICPP in the third quarter may also be related to disturbance of contaminated soil by construction near the air sampler.

The ${ }^{238} \mathrm{Pu}$ and ${ }^{239 / 240} \mathrm{Pu}$ found at $\mathrm{PBF}$ in the second quarter were investigated to determine a source. Two possible origins were considered: (1) the Waste Experimental Reduction Facility (WERF), a part of the PBF area, and (2) the ICPP facility about $5 \mathrm{~km}(3 \mathrm{mi})$ to the northwest. Filters from the stack at WERF, a facility which reduces the volume of low-level radioactive waste through processes such as incineration and compaction, are monitored on a regular basis. In 1995, no detectable alpha activity was found during the analysis of these filters. The presence of both isotopes of plutonium may eliminate windblown contaminated soil from the ICPP as a source, since only ${ }^{238} \mathrm{Pu}$ is found at above-background levels in soil near ICPP. Small quantities of both isotopes were reported released from the

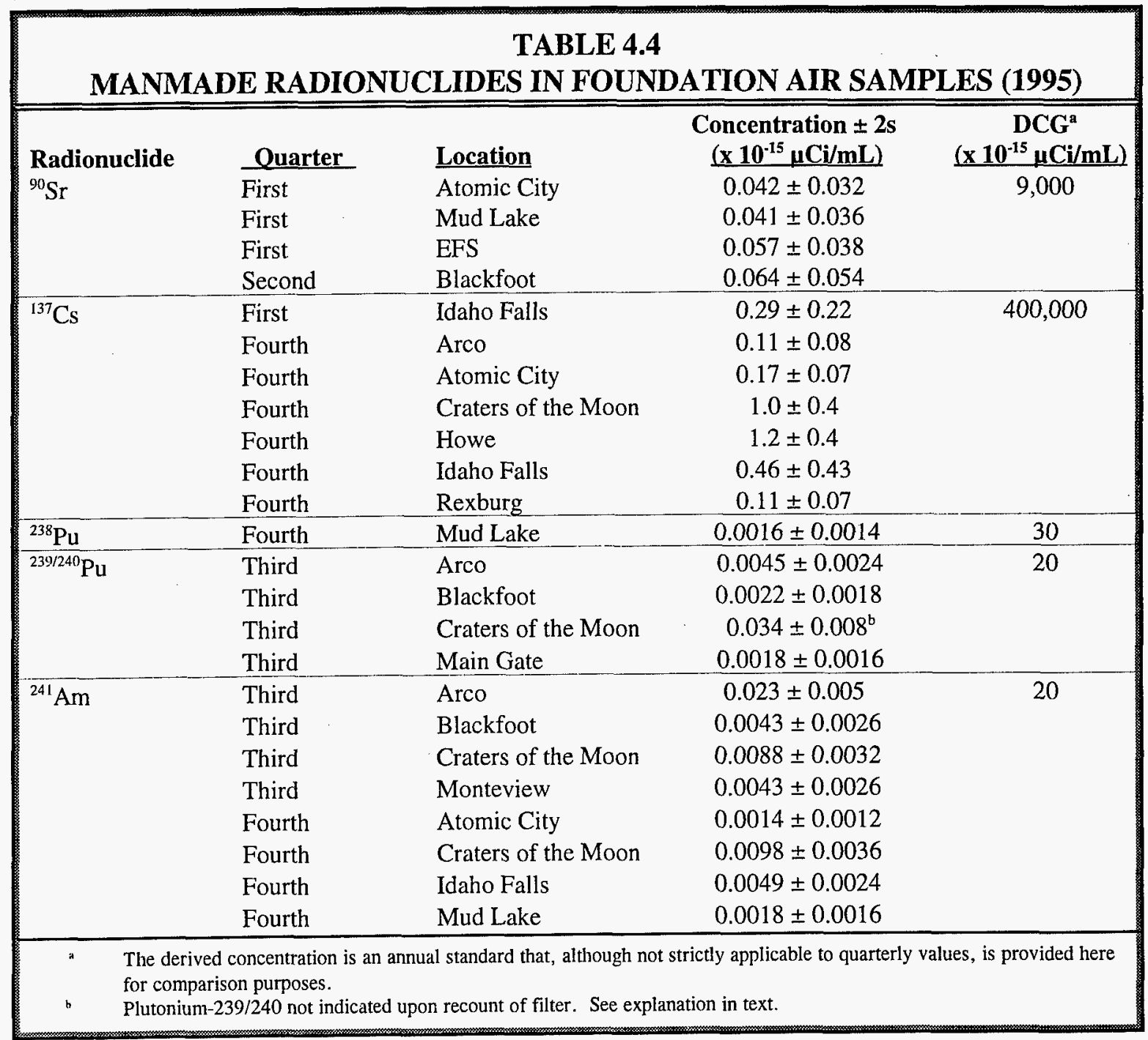


TABLE 4.5

MANMADE RADIONUCLIDES IN LITCO AIR SAMPLES (1995)

\begin{tabular}{|c|c|c|c|c|}
\hline Radionuclide & Quarter & Location & $\begin{array}{c}\text { Concentration } \pm 2 s \\
\left(x 10^{-15} \mu \mathrm{C} \mathbf{i} \pm \mathrm{mL}\right)\end{array}$ & $\begin{array}{c}\mathrm{DCG}^{\mathrm{a}} \\
\left(\times 10^{-15} \mu \mathrm{Ci} / \mathrm{mL}\right)\end{array}$ \\
\hline \multirow[t]{4}{*}{$\overline{{ }^{46} \mathrm{Sc}}$} & Third & $\overline{\text { Rexburg }}$ & $3.7 \pm 3.6$ & \multirow{4}{*}{600,000} \\
\hline & Third & NRF & $50 \pm 40$ & \\
\hline & Third & TRA & $5 \pm 4$ & \\
\hline & Fourth & Rexburg & $3.6 \pm 3.2$ & \\
\hline${ }^{60} \mathrm{Co}$ & First & PBF & $5 \pm 4$ & 80,000 \\
\hline \multirow[t]{13}{*}{${ }^{65} \mathrm{Zn}$} & First & Rexburg & $5 \pm 4$ & \multirow[t]{13}{*}{600,000} \\
\hline & First & CFA & $2.5 \pm 2.2$ & \\
\hline & First & EBR-1 & $6 \pm 4$ & \\
\hline & First & ICPP & $5 \pm 4$ & \\
\hline & First & NRF & $12 \pm 8$ & \\
\hline & Second & Blackfoot & $11 \pm 10$ & \\
\hline & Second & ARA & $7 \pm 6$ & \\
\hline & Second & NRF & $9 \pm 8$ & \\
\hline & Second & Van Buren & $7 \pm 6$ & \\
\hline & Third & ARA & $7 \pm 6$ & \\
\hline & Third & EBR-1 & $7 \pm 6$ & \\
\hline & Fourth & Rexburg & $5 \pm 4$ & \\
\hline & Fourth & NRF & $7 \pm 6$ & \\
\hline \multirow[t]{5}{*}{${ }^{90} \mathrm{Sr}$} & First & ARA & $0.12 \pm 0.06$ & \multirow[t]{5}{*}{9,000} \\
\hline & First & RWMC & $0.07 \pm 0.04$ & \\
\hline & First & Van Buren & $0.11 \pm 0.06$ & \\
\hline & Third & ICPP & $0.09 \pm 0.04$ & \\
\hline & Fourth & ICPP & $0.39 \pm 0.10$ & \\
\hline${ }^{94} \mathrm{Nb}$ & Fourth & TAN & $1.5 \pm 1.4$ & 40,000 \\
\hline \multirow{10}{*}{${ }^{110 \mathrm{mg}} \mathrm{Ag}$} & First & CFA & $0.8 \pm 0.6$ & \multirow[t]{10}{*}{200,000} \\
\hline & Second & Blackfoot & $3.4 \pm 2.6$ & \\
\hline & Second & Rexburg & $1.4 \pm 1.0$ & \\
\hline & Second & ANL-W & $1.9 \pm 1.4$ & \\
\hline & Second & CFA & $2.6 \pm 2.0$ & \\
\hline & Second & Van Buren & $2.4 \pm 2.2$ & \\
\hline & Third & CFA & $2.5 \pm 2.4$ & \\
\hline & Third & Van Buren & $2.3 \pm 1.8$ & \\
\hline & Fourth & Blackfoot & $2.2 \pm 2.0$ & \\
\hline & Fourth & Van Buren & $2.7 \pm 2.0$ & \\
\hline \multirow[t]{2}{*}{${ }^{144} \mathrm{Ce}$} & First & Craters of the Moon & $11 \pm 10$ & \multirow[t]{2}{*}{30,000} \\
\hline & Third & EBR-1 & $11 \pm 10$ & \\
\hline${ }^{203} \mathrm{Hg}$ & Fourth & TAN & $5 \pm 4$ & $3,000,000$ \\
\hline \multirow[t]{2}{*}{${ }^{238} \mathrm{Pu}$} & Second & PBF & $0.090 \pm 0.030$ & \multirow[t]{2}{*}{30} \\
\hline & Fourth & ICPP & $0.050 \pm 0.016$ & \\
\hline \multirow[t]{6}{*}{${ }^{239 / 240} \mathrm{Pu}$} & Second & EBR-1 & $0.0080 \pm 0.0030$ & \multirow[t]{6}{*}{20} \\
\hline & Second & PBF & $0.32 \pm 0.08$ & \\
\hline & Second & RWMC & $0.0040 \pm 0.0024$ & \\
\hline & Third & RWMC & $0.0040 \pm 0.0024$ & \\
\hline & Fourth & ANL-W & $0.0004 \pm 0.00036$ & \\
\hline & Fourth & ICPP & $0.021 \pm 0.008$ & \\
\hline \multirow[t]{5}{*}{${ }^{241} \mathrm{Am}$} & Second & Rexburg & $0.0060 \pm 0.0020$ & \multirow[t]{5}{*}{20} \\
\hline & Second & RWMC & $0.025 \pm 0.008$ & \\
\hline & Third & RWMC & $0.025 \pm 0.008$ & \\
\hline & Fourth & ICPP & $0.006 \pm 0.004$ & \\
\hline & Fourth & RWMC & $0.014 \pm 0.008$ & \\
\hline
\end{tabular}


Chapter 4: Environmental Radiological Program Information

ICPP during the year, but the amount of ${ }^{238} \mathrm{Pu}$ released was about six times higher than ${ }^{239 / 240} \mathrm{Pu}$. The two isotopes were in opposite proportions on the third quarter air filters, with ${ }^{239 / 240} \mathrm{Pu}$ higher by a factor of four. The origin of these two transuranic radionuclides in the third quarter is considered unknown at this time.

Plutonium-239/240 was reported on a filter from Craters of the Moon during the third quarter. A recount failed to indicate detectable plutonium activity, however. Re-examination of the spectra for the originial analysis by the laboratory indicated that the activity found was a peak for natural ${ }^{210} \mathrm{Po}$ activity that was shifted into the position for the plutonium peak by an electronic fault in the detector.

Americium-241 was reported at several offsite locations, including background sites, during the third and fourth quarters. Although this radionuclide is present in soil, the concentrations found appeared to be higher than would be expected if due to soil collected on the filters. The origin of the ${ }^{241} \mathrm{Am}$ has not been determined, but the lack of detectable concentrations on the filters from onsite indicate an INEL source is unlikely. Concentrations of ${ }^{241} \mathrm{Am}$ will be monitored to determine if trends are present in the concentrations.

\section{Atmospheric Moisture}

A total of 19 samples were collected in 1995 (nine onsite and 10 offsite). No tritium was found in any of the onsite samples. A somewhat lower detection limit was achieved for the offsite samples, and four contained a detectable concentration of tritium. Two detectable concentrations were found at the Idaho Falls background location and two at Atomic City. The highest concentration in air, $(7 \pm 2) \times 10^{-13} \mu \mathrm{Ci} / \mathrm{mL}$, was $0.0007 \%$ of the derived concentration guide. It is likely that the tritium results from natural processes and historic weapons testing.

\section{Precipitation}

A total of 43 precipitation samples were collected and analyzed. Tritium was detected in 12 of the samples at concentrations ranging from $(1.0 \pm 0.9) \times 10^{-7} \mu \mathrm{Ci} / \mathrm{mL}$ to $(1.9 \pm 1.7) \times 10^{-7} \mu \mathrm{Ci} / \mathrm{mL}$. The mean annual concentration was higher at the distant location of Idaho Falls than at the two INEL locations. Tritium attributable to INEL operations has been found in isolated precipitation samples during the previous few years, but the higher concentration of tritium at the background sampling location indicates it is more likely that these concentrations are environmental tritium resulting from natural atmospheric processes and historic nuclear weapons testing. The detection limit achieved in 1995 for tritium was also lower than in previous years due to the use of a newer counting system.

\section{Water Sampling Results}

Note: The DOE Order governing preparation of Annual Site Environmental Reports (DOE 5400.1) recommends using units of $\mu \mathrm{Ci} / \mathrm{mL}$ for concentrations of radionuclides in water. However, 40 CFR 141 gives the EPA maximum contaminant levels in units of $\mathrm{pCi} / \mathrm{L}$. For the reader's convenience, concentrations of radionuclides in water samples will be shown with exponents that allow easy conversion to EPA units:

$$
\begin{aligned}
& 1 \times 10^{-9} \mu \mathrm{Ci} / \mathrm{mL}=1 \mathrm{pCi} / \mathrm{L} \\
& 1 \times 10^{-6} \mu \mathrm{Ci} / \mathrm{mL}=1000 \mathrm{pCi} / \mathrm{L} .
\end{aligned}
$$

Gross Alpha. Fifty-one offsite samples were collected in 1995 (32 drinking water and 19 
surface water samples). Four had gross alpha concentrations above the minimum detectable concentration. The highest reported value, in a surface water sample from the Snake River at Bliss, was $(11 \pm 7) \times 10^{-9} \mu \mathrm{Ci} / \mathrm{mL}$. A recount failed to indicate detectable gross alpha activity in this sample, and a second fraction was analyzed and no gross alpha activity was found. For perspective, this concentration is $35 \%$ of the annual derived concentration guide and about $70 \%$ of the EPA maximum contaminant level.

Of the 224 onsite production well samples collected during 1995, a total of 15 samples contained gross alpha above the minimum detectable concentration, the highest of which was $(5 \pm 4) \times 10^{-9} \mu \mathrm{Ci} / \mathrm{mL}$. This value is $33 \%$ of the EPA maximum contaminant level for gross alpha in drinking water.

All confirmed gross alpha concentrations were within the expected concentration range for naturally-occurring alpha activity in the aquifer underlying the Snake River Plain, including the INEL. According to USGS reports, alpha-emitting wastes from INEL operations have not migrated far from their entrance into the aquifer near ICPP. The offsite gross alpha activity is unlikely to be due to migration of wastes from INEL operations, and all onsite drinking water wells lie outside the migration plumes for alpha-emitting nuclides. The probable source of gross alpha activity is from natural radioactivity that occurs in the Snake River Plain Aquifer.

Gross Beta. Gross beta activity above the minimum detectable concentration was present in 34 of the 51 offsite water samples. A lower detection limit for gross beta was achieved in 1995 than in previous years, resulting in an increase in the number of samples with detectable activity. Detectable concentrations ranged from $(1.8 \pm 1.6) \times 10^{-9} \mu \mathrm{Ci} / \mathrm{mL}$ to $(30 \pm 3) \times 10^{-9} \mu \mathrm{Ci} / \mathrm{mL}$. Concentrations for all samples were within the expected concentration range for natural radioactivity with the exception of the November sample from the Snake River at Idaho Falls. A second fraction of this sample was analyzed and indicated no detectable gross beta concentrations. Examination of the counting planchet on which the first fraction was evaporated revealed a high residue content indicating that the source of the gross beta activity in the first fraction may have been excess sediment in the sample. For perpective, the concentration found in the first fraction represents about $30 \%$ of the DOE derived concentration guide and $60 \%$ of the EPA maximum contaminant level.

Of the 224 onsite production well samples, 39 had concentrations of gross beta that were above the minimum detectable concentration. All were within the range typically found for background concentrations from natural radioactivity that occurs in the Snake River Plain Aquifer, except for three samples from the ICPP taken in June, the highest of which was $(27 \pm 10) \times 10^{-9} \mu \mathrm{Ci} / \mathrm{mL}$. This value is $54 \%$ of the EPA maximum contaminant level for gross beta in drinking water. The elevated levels of gross beta at ICPP may be related to the increase in ${ }^{90} \mathrm{Sr}$ concentrations in water samples seen at the facility during June. These results are discussed further in a later section.

Tritium. Tritium was found above the minimum detectable concentration in four offsite drinking water and four offsite surface water samples. The highest concentration, $(0.37 \pm 0.16) \times 10^{-6} \mu \mathrm{Ci} / \mathrm{mL}$ from Shoshone in May, was $0.02 \%$ of the DOE derived concentration guide and $2 \%$ of the EPA maximum contaminant level. The detection limit achieved for offsite water samples in 1995 
Chapter 4: Environmental Radiological Program Information

was somewhat lower than in previous years, which was generally about $0.5 \times 10^{-6} \mu \mathrm{Ci} / \mathrm{mL}$. Water samples taken simultaneously by the State of Idaho Oversight Program and analyzed by the same laboratory did not contain tritium above the detection limit in several instances, indicating that reported tritium concentratrions may result from statistical variations in the analytical results. Results for the two sets of samples are compared in Chapter 7, "Quality Assurance."

Water from four of the onsite production wells and one drinking water distribution system that were routinely sampled showed detectable concentrations of tritium each month (Table 4.6). Figure 4.5 shows five years of tritium data for the four production wells. In addition to these four wells, three samples from ICPP well \#1 and one from the ICPP distribution system contained detectable concentrations of tritium. All detectable results for ICPP samples were either $(0.5 \pm 0.4) \times 10^{-6}$ $\mu \mathrm{Ci} / \mathrm{mL}$ or $(0.6 \pm 0.4) \times 10^{-6} \mu \mathrm{Ci} / \mathrm{mL}$. No other onsite drinking water samples contained detectable tritium concentrations.

Strontium-90. This radionuclide was found at concentrations above the minimum detectable concentration in one of three samples from well ICPP \#1, two of nine samples from well ICPP \#2, and two of eight samples from well ICPP \#4 (Table 4.7). Well ICPP \#5 and the ICPP distribution system showed no detectable ${ }^{90} \mathrm{Sr}$. Both well \#1 and well \#4 showed a sharp increase in ${ }^{90} \mathrm{Sr}$ concen-trations during June sampling, to $(7.3 \pm 1.6) \times 10^{-9} \mu \mathrm{Ci} / \mathrm{mL}$ and $(6.8 \pm 1.6) \times 10^{-9} \mu \mathrm{Ci} / \mathrm{mL}$, respectively. Strontium-90 has commonly been found in well $\# 1$, generally at about $1 \times 10^{-9} \mu \mathrm{Ci} / \mathrm{mL}$ while previous concentrations in well \#4 have been near the detection limit of $0.5 \times 10^{-9} \mu \mathrm{Ci} / \mathrm{mL}$. The cause of the increase during the single month is not known, but the June concentrations remained less than the EPA maximum contaminant level as shown in Table 4.6.

\begin{tabular}{|c|c|c|c|c|c|c|}
\hline \multicolumn{7}{|c|}{$\begin{array}{c}\text { TABLE } 4.6 \\
\text { TRITIUM CONCENTRATIONS IN INEL PRODUCTION WELLS (1995) }\end{array}$} \\
\hline \multirow[b]{2}{*}{ Well Code } & \multirow{2}{*}{$\begin{array}{c}\begin{array}{c}\text { \# of } \\
\text { Samples }^{b}\end{array} \\
\end{array}$} & \multicolumn{3}{|c|}{$\begin{array}{l}\text { Tritium Concentration } \\
\left(\times 10^{-6} \mu \mathrm{Ci} / \mathrm{mL}\right)^{\mathrm{a}}\end{array}$} & \multirow{2}{*}{\multicolumn{2}{|c|}{ \% $\mathrm{MCL}^{\mathrm{e}} \% \mathrm{DCG}$}} \\
\hline & & $\underline{\text { Minimum }}^{\mathrm{c}}$ & $\underline{\text { Maximum }}^{\mathrm{c}}$ & $\underline{\text { Mean }}^{\mathrm{d}}$ & & \\
\hline$\overline{\text { CFA }^{\mathrm{f}}}$ & 10 & $12.0 \pm 1.0$ & $18.1 \pm 1.0$ & $14.4 \pm 1.7$ & 72 & 0.7 \\
\hline CFA \#1 & 10 & $12.5 \pm 0.8$ & $18.0 \pm 1.0$ & $14.4 \pm 1.2$ & 72 & 0.7 \\
\hline CFA \#2 & 8 & $12.0 \pm 1.0$ & $16.0 \pm 1.0$ & $13.6 \pm 1.4$ & 68 & 0.7 \\
\hline Rifle Range & 10 & $3.3 \pm 0.6$ & $3.7 \pm 0.6$ & $3.5 \pm 0.1$ & 18 & 0.2 \\
\hline RWMC & 10 & $1.3 \pm 0.4$ & $1.6 \pm 0.4$ & $1.5 \pm 0.1$ & 8 & 0.08 \\
\hline \multicolumn{7}{|c|}{$\begin{array}{l}\text { Equivalent to } \mathrm{pCi} / \mathrm{mL} \text {. } \\
\text { Samples taken only from wells in use at collection time. } \\
\text { Tritium concentration } \pm 2 \mathrm{~s} \text {. } \\
\text { Arithmetic mean with the } 95 \% \text { confidence interval for the mean. } \\
\text { EPA drinking water } \mathrm{MCL} \text { (maximum contaminant level) for tritium is } 20 \times 10^{6} \mu \mathrm{Ci} / \mathrm{mL} \text {. } \\
\text { Samples collected from the Central Facilities Area distribution system. }\end{array}$} \\
\hline
\end{tabular}




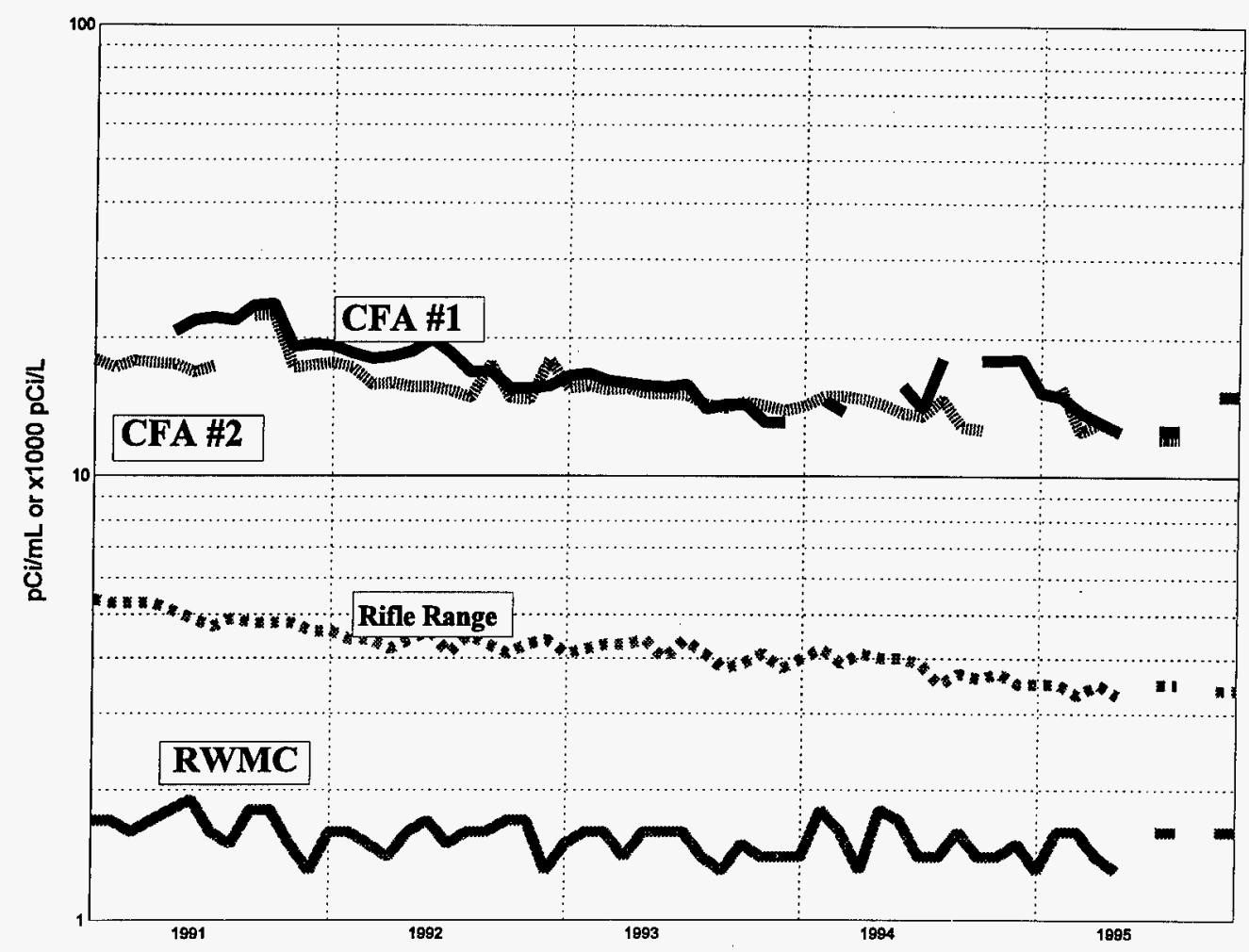

Figure 4.5 Tritium Concentrations in INEL Production Wells (1991-1995)

CFA Worker Dose. The potential effective dose equivalent to a worker at CFA from radioactivity in water was calculated. CFA was selected because the tritium concentrations found in these wells were the highest of any drinking water wells. The 1995 calculation was based on:

- Mean tritium concentration for the CFA distribution system in 1995 as shown in Table 4.6

- Data from a 1990-91 USGS study for ${ }^{129} I$ using the accelerator mass spectrographic analytical technique that indicated water from CFA \#1 contained ${ }^{129} \mathrm{I}$ at an average concentration of $(0.26 \pm 0.05) \times 10^{-9}$ $\mu \mathrm{Ci} / \mathrm{mL}$ and water from CFA \#2 had an average concentration of $(0.14 \pm 0.03) \mathrm{x}$
$10^{-9} \mu \mathrm{Ci} / \mathrm{mL}$. For perspective, the proposed EPA drinking water standard for ${ }^{129} \mathrm{I}$ in drinking water is $21 \times 10^{-9} \mu \mathrm{Ci} / \mathrm{mL}$.

- Water usage information for 1995 showing CFA \#2 was used for approximately $62 \%$ of the drinking water and CFA \#1 was used for $38 \%$ of the drinking water.

For the 1995 dose calculation, the assumption was made that each worker's total water intake came from the CFA drinking water distribution system. This assumption overestimates the dose because workers typically consume only about half their total intake during working hours and typically work only 240 days rather than 365 days per year. The estimated effective dose equivalent to a worker from consuming all drinking water at CFA 
Chapter 4: Environmental Radiological Program Information

\begin{tabular}{|c|c|c|c|c|c|c|}
\hline \multicolumn{7}{|c|}{$\begin{array}{c}\text { TABLE } 4.7 \\
{ }^{90} \text { SR CONCENTRATIONS IN ICPP PRODUCTION WELLS (1995) }\end{array}$} \\
\hline \multirow{7}{*}{$\begin{array}{l}\text { Well Code } \\
\text { ICPP \#1 } \\
\text { ICPP \#2 } \\
\text { ICPP \#4 } \\
\text { ICPP \#5 } \\
\text { ICPP } 614^{\text {f }}\end{array}$} & \multicolumn{4}{|c|}{$\begin{array}{l}{ }^{90} \mathrm{Sr} \text { Concentration } \\
\left(\times 10^{-9} \mu \mathrm{Ci} / \mathrm{mL}\right)^{\mathrm{a}}\end{array}$} & \multirow{2}{*}{\multicolumn{2}{|c|}{ \%MCL \%DCG }} \\
\hline & $\begin{array}{c}\text { \# of } \\
\text { Samples }^{b}\end{array}$ & Minimum & Maximum $^{c}$ & Mean $^{d}$ & & \\
\hline & 3 & $<m d c^{\mathrm{e}}$ & $7.3 \pm 1.6$ & $3.1 \pm 9.1$ & 39 & 0.3 \\
\hline & 9 & $<\mathrm{mdc}$ & $0.4 \pm 0.2$ & $0.3 \pm 0.2$ & 4 & 0.03 \\
\hline & 8 & $<\mathrm{mdc}$ & $6.8 \pm 1.6$ & $0.8 \pm 2.1$ & 10 & 0.08 \\
\hline & 4 & $<\mathrm{mdc}$ & $<\operatorname{mdc}$ & $-0.2 \pm 0.2$ & N/A & N/A \\
\hline & 3 & $<\mathrm{mdc}$ & $<\mathrm{mdc}$ & $0.2 \pm 0.4$ & 3 & 0.02 \\
\hline $\begin{array}{ll} & \text { Equival } \\
\text { b } & \text { Samples } \\
\text { : } & \text { Maximu } \\
\text { : } & \text { Arithm } \\
\text { : } & \text { Below } \\
\text { : } & \text { Samples }\end{array}$ & $\begin{array}{l}\text { Ci/L. } \\
\text { only from well } \\
\text { centration amor } \\
\text { an with the } 95 \% \\
\text { imum detectabl } \\
\text { ted from the IC }\end{array}$ & $\begin{array}{l}\text { use at collection } \\
\text { mples in which } \\
\text { nfidence interval } \\
\text { ncentration. } \\
\text { distribution syste }\end{array}$ & $\begin{array}{l}\text { ium-90 was consi } \\
\text { nean. }\end{array}$ & letectable. & & \\
\hline
\end{tabular}

during 1995 was 0.7 mrem, $18 \%$ of the EPA standard of 4 mrem for community drinking water systems.

\section{Foodstuff Sampling Results}

Milk. Of the 144 milk samples collected during 1995, one from Roberts in May contained ${ }^{131} \mathrm{I}$ just above the minimum detectable concentration at $(9.1 \pm 8.7) \times 10^{-9} \mu \mathrm{Ci} / \mathrm{mL}$.

Tritium was detected in none of the four samples analyzed for that radionuclide in May, and in all five samples analyzed in November when a somewhat lower detection limit was achieved. Concentrations were similar at distant and boundary locations, and were similar to environmental levels of tritium found in offsite water and precipitation samples. The highest concentration was $(1.7 \pm 0.9) \times 10^{-7} \mu \mathrm{Ci} / \mathrm{mL}$, reported in the sample from the distant location of Blackfoot.

Six of seven samples analyzed for ${ }^{90} \mathrm{Sr}$ (two were lost during analysis) had detectable concentrations ranging from $(7 \pm 3) \times 10^{-10}$ $\mu \mathrm{Ci} / \mathrm{mL}$ at the Terreton location to $(1.3 \pm 0.7) \times 10^{-9} \mu \mathrm{Ci} / \mathrm{mL}$ at Dietrich. All levels of ${ }^{90} \mathrm{Sr}$ in milk were consistent with those previously reported by the EPA as resulting from world-wide fallout deposited on soil, then taken up by consumption of grass by cows ${ }^{\mathrm{a}}$.

Lettuce. Two samples contained detectable ${ }^{137} \mathrm{Cs}$ concentrations and all but one contained ${ }^{90} \mathrm{Sr}$ (one sample was lost in analysis). Both the maximum ${ }^{137} \mathrm{Cs}$ concentration of $(4.8 \pm 0.2)$ $\mathrm{x} 10^{-6} \mu \mathrm{Ci} / \mathrm{g}$ and maximum ${ }^{90} \mathrm{Sr}$ concentration (Table 4.8) were found at the distant location of Blackfoot. The distant group mean ${ }^{90} \mathrm{Sr}$ concentration was higher than the boundary group mean, although the range of results was quite large. Both ${ }^{137} \mathrm{Cs}$ and ${ }^{90} \mathrm{Sr}$ are present in soil from above-ground nuclear weapons testing that took place primarily in the 1950 s and 1960 s.

a U.S. Environmental Protection Agency, Environmental Radiation Data Reports 70-73, 1993. 


\section{TABLE 4.8}

${ }^{90}$ SR CONCENTRATIONS IN GARDEN LETTUCE (1991-1995)

\begin{tabular}{|c|c|c|c|c|c|}
\hline \multirow[b]{2}{*}{ Sample Location } & \multicolumn{5}{|c|}{${ }^{90} \mathrm{Sr}$ Concentration $\left(\times 10^{-9} \mu \mathrm{Ci} / \mathrm{g} \text { dry weight }\right)^{\mathrm{a}}$} \\
\hline & 1991 & $\underline{1992}$ & $\underline{1993}$ & $\underline{1994}$ & $\underline{1995}$ \\
\hline \multicolumn{6}{|l|}{ Distant Group: } \\
\hline Blackfoot & $170 \pm 80$ & $---{ }^{b}$ & $-30 \pm 60$ & $160 \pm 80$ & $740 \pm 200$ \\
\hline Carey & $210 \pm 80$ & $200 \pm 40$ & $-70 \pm 50$ & $130 \pm 40$ & $-50 \pm 180$ \\
\hline Idaho Falls & $170 \pm 100$ & $230 \pm 40$ & $-80 \pm 50$ & $120 \pm 40$ & $60 \pm 30$ \\
\hline \multirow[t]{2}{*}{ Pocatello } & $\underline{190 \pm 40}$ & $80 \pm 40$ & $180 \pm 140$ & $\ldots \omega^{b}$ & $-c^{-} \mathrm{b}$ \\
\hline & $190 \pm 30$ & $170 \pm 200$ & $0 \pm 190$ & $140 \pm 50$ & $250 \pm 1050$ \\
\hline \multicolumn{6}{|l|}{ Boundary Group: } \\
\hline Arco & $80 \pm 40$ & $50 \pm 40$ & $90 \pm 90$ & $50 \pm 40$ & $140 \pm 50$ \\
\hline Atomic City & $310 \pm 120$ & $210 \pm 60$ & $-80 \pm 60$ & $200 \pm 60$ & $300 \pm 120$ \\
\hline Howe & $50 \pm 40$ & $80 \pm 40$ & $N S^{d}$ & $N S^{d}$ & $\mathrm{NS}^{\mathrm{d}}$ \\
\hline Monteview & NS & NS & $210 \pm 80$ & $110 \pm 40$ & $100 \pm 90$ \\
\hline Mud Lake/Terreton & $170 \pm 80$ & $150 \pm 40$ & $40 \pm 70$ & $70 \pm 60$ & $\underline{80+40}$ \\
\hline$M e a n^{\mathrm{c}}$ & $150 \pm 160$ & $120 \pm 110$ & $70 \pm 190$ & $110 \pm 100$ & $160 \pm 160$ \\
\hline $\begin{array}{l}\text { Analytical results } \pm 2 \text { s. Approxir } \\
\text { - Sample lost in preparation or analy } \\
\text { A Arithmetic mean with the } 95 \% \text { con } \\
\text { A No sample was collected at this lo }\end{array}$ & $\begin{array}{l}\text { inimum de } \\
\text { ce interval } \\
\text { during the }\end{array}$ & $\begin{array}{l}\text { concentrati } \\
\text { mean. }\end{array}$ & ${ }^{90} \mathrm{Sr}$ in lettuce & $10^{-9} \mu \mathrm{Ci} / \mathrm{g}$ & \\
\hline
\end{tabular}

Wheat. No manmade gamma-emitting radionuclides were found above the minimum detectable concentration in 1995 wheat samples. Measurable concentrations of ${ }^{90} \mathrm{Sr}$ were seen in most samples (Table 4.9). The results shown in Table 4.9 are from a reanalysis performed on the wheat after the first set of results was rejected during data validation due to low chemical yields and spiked sample recoveries. Because one of the results reported with the rejected set of data was outside the normal range found for ${ }^{90} \mathrm{Sr}$, an additional fraction of this sample was analyzed again and verified that the result obtained from the second (and accepted) set of results was accurate.

Potatoes. No gamma-emitting radionuclides were observed at the five locations sampled (three distant and two boundary). Strontium-90 was detected in four of the five samples, with similar concentrations reported at distant and boundary locations. The highest ${ }^{90} \mathrm{Sr}$ concentration reported was found in the Mud Lake sample at $(1.7 \pm 0.7) \times 10^{-8} \mu \mathrm{Ci} / \mathrm{mL}$. The ${ }^{90} \mathrm{Sr}$ likely results from this radionuclide's universal presence in soil from above-ground nuclear weapons testing.

Sheep. Cesium-137 was detected in the muscle tissue of three of the four onsite sheep and one of the two offsite sheep. The maximum concentration, found in a sheep that grazed in the southern and eastern portions of the INEL, was $(1.2 \pm 0.8) \times 10^{-8} \mu \mathrm{Ci} / \mathrm{g}$. All ${ }^{137} \mathrm{Cs}$ concentrations were similar to those found in both onsite and offsite sheep samples during 
Chapter 4: Environmental Radiological Program Information

TABLE 4.9

${ }^{90}$ SR CONCENTRATIONS IN WHEAT (1991-1995)

\begin{tabular}{|c|c|c|c|c|c|c|}
\hline \multirow[b]{2}{*}{ Sample Location } & & \multicolumn{5}{|c|}{${ }^{90} \mathrm{Sr}$ Concentration $\left(10^{-9} \mu \mathrm{Ci} / \mathrm{g} \text { dry weight }\right)^{\mathrm{a}}$} \\
\hline & & $\underline{1991}$ & $\underline{1992}$ & $\underline{1993}$ & $\underline{1994}$ & $\underline{1995}$ \\
\hline \multicolumn{7}{|l|}{ Distant Group: } \\
\hline American Falls & & $10 \pm 4$ & $11 \pm 2$ & $2 \pm 2$ & $7 \pm 2$ & $8 \pm 4$ \\
\hline Blackfoot & & $10 \pm 3$ & $7 \pm 2$ & $2 \pm 4$ & $7 \pm 2$ & $4 \pm 4$ \\
\hline Carey & & $\mathrm{NS}^{\mathrm{b}}$ & $10 \pm 2$ & $2 \pm 4$ & $2 \pm 2$ & $11 \pm 7$ \\
\hline Dietrich & & $6 \pm 3$ & NS & $-1 \pm 4$ & $3 \pm 2$ & NS \\
\hline Idaho Falls & & $9 \pm 3$ & $9 \pm 2$ & $0 \pm 3$ & $6 \pm 2$ & $9 \pm 5$ \\
\hline Minidoka & & $8 \pm 4$ & $7 \pm 2$ & $4 \pm 4$ & $6 \pm 2$ & $3+5$ \\
\hline & $\operatorname{Mean}^{c}$ & $8 \pm 2$ & $9 \pm 2$ & $2 \pm 2$ & $5 \pm 2$ & $7 \pm 4$ \\
\hline \multicolumn{7}{|l|}{ Boundary Group: } \\
\hline Arco & & $10 \pm 3$ & $10 \pm 2$ & $-1 \pm 3$ & $4 \pm 2$ & $3 \pm 5$ \\
\hline Monteview & & $3 \pm 3$ & $9 \pm 2$ & $1 \pm 4$ & $7 \pm 3$ & $4 \pm 4$ \\
\hline Mud Lake & & $9 \pm 3$ & $4 \pm 2$ & $2 \pm 4$ & $5 \pm 2$ & $4 \pm 5$ \\
\hline Tabor & & $15 \pm 4$ & $8 \pm 2$ & $0 \pm 6$ & $8 \pm 2$ & $12 \pm 6$ \\
\hline Terreton & & $5 \pm 3$ & $3 \pm 2$ & $1 \pm 2$ & $\underline{5 \pm 2}$ & $7+5$ \\
\hline & $M_{e a n^{c}}$ & $8 \pm 6$ & $7 \pm 4$ & $1 \pm 1$ & $6 \pm 2$ & $6 \pm 5$ \\
\hline
\end{tabular}

recent years, and are likely due to worldwide fallout.

Game Animals. A total of five large game animals were sampled during 1995, three pronghorn and two mule deer. Cesium-137 was found in muscle tissue of three animals and the liver of two animals. Concentrations of ${ }^{137} \mathrm{Cs}$ were $(1.5 \pm 0.9) \times 10^{-8} \mu \mathrm{Ci} / \mathrm{g}$ or less. In addition, ${ }^{60} \mathrm{Co}$ was found in the muscle tissue of one pronghorn just above the minimum detectable concentration at $(4.3 \pm 4.2) \times 10^{-9}$. Soil contaminated with both of these radionuclides are found around some facilities at the INEL, and it is possible that they were present in game animals due to ingestion of contaminated soil particles, or ingestion of vegetation grown in contaminated soil. The ${ }^{137} \mathrm{Cs}$ concentrations found, however, were similar to those found in onsite and offsite sheep during the past few years and may also have resulted from worldwide fallout.

Three small fish were collected from the Big Lost River in the southern portion of the INEL. Due to their small size, these fish were composited into one sample. No manmade gamma-emitting radionuclides were found in the fish sample.

Waterfowl samples were collected from a control area distant from the INEL near Fort Hall, and from disposal ponds at four INEL facilities (Table 4.10). Edible portions of these birds were submitted for gamma spectrometry, and several gamma-emitting radionuclides were 
1995 INEL Annual Site Environmental Report

\begin{tabular}{|c|c|c|c|c|}
\hline \multicolumn{5}{|c|}{$\begin{array}{l}\text { TABLE } 4.10 \\
\text { MANMADE GAMMA-EMITTING RADIONUCLIDES IN } \\
\text { EDIBLE PORTIONS OF WATERFOWL (1995) }\end{array}$} \\
\hline \multirow{7}{*}{$\frac{\text { Radionuclide }}{{ }^{{ }^{1} \mathrm{Cr}}}$} & \multirow{7}{*}{$\begin{array}{l}\text { Location } \\
\text { Control } \\
\text { ANL-W } \\
\text { ICPP } \\
\text { TAN } \\
\text { TRA }\end{array}$} & \multicolumn{3}{|c|}{ Concentration $\left(\times 10^{-6} \mu \mathrm{Ci} / g\right)$} \\
\hline & & Minimum $^{\mathrm{a}}$ & Maximum $^{0}$ & $\underline{\text { Mean }}^{b}$ \\
\hline & & $<\mathrm{mdc}^{\mathrm{c}}$ & $2.8 \pm 2.1$ & $\overline{1.0 \pm 0.9}$ \\
\hline & & $<\mathrm{mdc}$ & $<\mathrm{mdc}$ & $-{ }^{-}$d \\
\hline & & $<\mathrm{mdc}$ & $<$ mdc & ----- \\
\hline & & $<\mathrm{mdc}$ & $3.7 \pm 2.4$ & $1.2 \pm 4.3$ \\
\hline & & $<\mathrm{mdc}$ & $<\mathrm{mdc}$ & ----- \\
\hline \multirow[t]{5}{*}{${ }^{54} \mathrm{Mn}$} & Control & $<\mathrm{mdc}$ & $0.07 \pm 0.06$ & $0.01 \pm 0.01$ \\
\hline & ANL-W & $<\mathrm{mdc}$ & $<\mathrm{mdc}$ & --- \\
\hline & ICPP & $<\mathrm{mdc}$ & $0.02 \pm 0.02$ & $0.01 \pm 0.02$ \\
\hline & TAN & $<\mathrm{mdc}$ & $0.06 \pm 0.04$ & $0.02 \pm 0.07$ \\
\hline & TRA & $<\mathrm{mdc}$ & $0.08 \pm 0.08$ & $0.02 \pm 0.03$ \\
\hline \multirow[t]{5}{*}{${ }^{58} \mathrm{Co}$} & Control & $<m d c$ & $0.6 \pm 0.5$ & $0.10 \pm 0.15$ \\
\hline & ANL-W & $<m d c$ & $<\mathrm{mdc}$ & --- \\
\hline & ICPP & $<m d c$ & $0.07 \pm 0.06$ & $0.02 \pm 0.07$ \\
\hline & TAN & $<\mathrm{mdc}$ & $<\mathrm{mdc}$ & -- \\
\hline & TRA & $<m d c$ & $0.14 \pm 0.14$ & $0.03 \pm 0.06$ \\
\hline \multirow[t]{5}{*}{${ }^{60} \mathrm{Co}$} & Control & $<m d c$ & $<\mathrm{mdc}$ & $\cdots$ \\
\hline & ANL-W & $<\mathrm{mdc}$ & $<$ mdc & -.-- \\
\hline & ICPP & $0.02 \pm 0.02$ & $0.16 \pm 0.04$ & $0.07 \pm 0.02$ \\
\hline & TAN & $<\mathrm{mdc}$ & $<\mathrm{mdc}$ & -- \\
\hline & TRA & $<$ mdc & $0.17 \pm 0.08$ & $0.04 \pm 0.07$ \\
\hline \multirow[t]{5}{*}{${ }^{65} \mathrm{Zn}$} & Control & $<\mathrm{mdc}$ & $0.18 \pm 0.18$ & $0.02 \pm 0.03$ \\
\hline & ANL-W & $<\mathrm{mdc}$ & $<\mathrm{mdc}$ & ---- \\
\hline & ICPP & $0.06 \pm 0.06$ & $0.10 \pm 0.06$ & $0.08 \pm 0.05$ \\
\hline & TAN & $<\mathrm{mdc}$ & $<\mathrm{mdc}$ & --..- \\
\hline & TRA & $<\mathrm{mdc}$ & $<$ mdc & ---- \\
\hline \multirow[t]{5}{*}{${ }^{95} \mathrm{Nb}$} & Control & $<\mathrm{mdc}$ & $<\mathrm{mdc}$ & -- \\
\hline & ANL-W & $<\mathrm{mdc}$ & $<\mathrm{mdc}$ & --.-- \\
\hline & ICPP & $<\mathrm{mdc}$ & $<$ mdc & --.- \\
\hline & TAN & $<\mathrm{mdc}$ & $0.4 \pm 0.3$ & $0.1 \pm 0.4$ \\
\hline & TRA & $<\mathrm{mdc}$ & $<\mathrm{mdc}$ & $-\cdots$ \\
\hline \multirow[t]{5}{*}{${ }^{134} \mathrm{Cs}$} & Control & $<m d c$ & $0.08 \pm 0.04$ & $0.02 \pm 0.01$ \\
\hline & ANL-W & $<\mathrm{mdc}$ & $<\mathrm{mdc}$ & ---- \\
\hline & ICPP & $<\mathrm{mdc}$ & $0.04 \pm 0.02$ & $0.01 \pm 0.05$ \\
\hline & TAN & $<\mathrm{mdc}$ & $<\mathrm{mdc}$ & ---- \\
\hline & TRA & $<\mathrm{mdc}$ & $<\mathrm{mdc}$ & ---- \\
\hline \multirow[t]{5}{*}{${ }^{137} \mathrm{Cs}$} & Control & $<\mathrm{mdc}$ & $0.08 \pm 0.06$ & $0.01 \pm 0.01$ \\
\hline & ANL-W & $<m d c$ & $0.03 \pm 0.02$ & $0.02 \pm 0.05$ \\
\hline & ICPP & $<\mathrm{mdc}$ & $0.57 \pm 0.08$ & $0.21 \pm 0.65$ \\
\hline & TAN & $<\mathrm{mdc}$ & $1.8 \pm 0.2$ & $1.0 \pm 1.4$ \\
\hline & TRA & $<\mathrm{mdc}$ & $<$ mdc & ---- \\
\hline \multirow[t]{5}{*}{${ }^{144} \mathrm{Ce}$} & Control & $<\mathrm{mdc}$ & $<\mathrm{mdc}$ & $-\ldots$ \\
\hline & ANL-W & $<\mathrm{mdc}$ & $<\mathrm{mdc}$ & --- \\
\hline & ICPP & $<\mathrm{mdc}$ & $0.16 \pm 0.10$ & $0.05 \pm 0.02$ \\
\hline & TAN & $<\mathrm{mdc}$ & $<\mathrm{mdc}$ & $\cdots$ \\
\hline & TRA & $<\mathrm{mdc}$ & $<\mathrm{mdc}$ & --- \\
\hline \multirow[t]{5}{*}{${ }^{181} \mathrm{Hf}$} & Control & $<m d c$ & $2.6 \pm 2.2$ & $0.3 \pm 0.5$ \\
\hline & ANL-W & $<\mathrm{mdc}$ & $<\mathrm{mdc}$ & ---- \\
\hline & ICPP & $<\mathrm{mdc}$ & $0.15 \pm 0.14$ & $0.07 \pm 0.17$ \\
\hline & TAN & $<\mathrm{mdc}$ & $<\mathrm{mdc}$ & -.-. \\
\hline & TRA & $<\mathrm{mdc}$ & $<\mathrm{mdc}$ & ----- \\
\hline $\begin{array}{ll}\text { b } & \text { Concentrati } \\
\text { c } & \text { Lean with } \mathrm{S} \\
\text { d } & \text { There were }\end{array}$ & $\begin{array}{l}\text { dard deviatic } \\
\text { lence interva } \\
\text { tectable con }\end{array}$ & 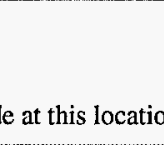 & & \\
\hline
\end{tabular}


found. Most concentrations were similar at the control location and the onsite locations, indicating they were likely present due to statistical variations in the analytical results. Cesium-137 appeared at above-background concentrations in all three samples from the TAN Technical Services Facility disposal pond. This pond, not currently used for disposal of radioactive liquids, is located in an area of soil slightly contaminated with ${ }^{137} \mathrm{Cs}$. Further information on the potential dose from consuming waterfowl from INEL ponds is provided in a section on the game ingestion pathway later in this chapter.

\section{Environmental Dosimeters}

The measured cumulative radiation exposure for offsite locations for the time period from November 1994 to November 1995 is shown in Table 4.11 for the duplicate set of dosimeters maintained by the Foundation and

\begin{tabular}{|c|c|c|c|c|c|c|}
\hline \multicolumn{7}{|c|}{$\begin{array}{l}\text { TABLE } 4.11 \\
\text { ENVIRONMENTAL RADIATION EXPOSURES (1991-1995) }\end{array}$} \\
\hline \multirow[b]{2}{*}{ Location } & \multicolumn{6}{|c|}{ Annual Exposure $(\mathbf{m R})^{\mathrm{a}}$} \\
\hline & \multirow[t]{2}{*}{1991} & \multirow[t]{2}{*}{$\underline{1992}$} & \multirow[t]{2}{*}{$\underline{1993}$} & \multirow[t]{2}{*}{$\underline{1994}$} & \multicolumn{2}{|c|}{1995} \\
\hline Distant Group: & & & & & Foundation & $\underline{\mathrm{LITCO}}$ \\
\hline Aberdeen & $126 \pm 5$ & $--^{\mathrm{b}}$ & $99 \pm 3$ & $120 \pm 4$ & $108 \pm 3$ & $110 \pm 4$ \\
\hline Blackfoot & $122 \pm 6$ & $122 \pm 4$ & $111 \pm 4$ & $125 \pm 5$ & $117 \pm 4$ & $118 \pm 4$ \\
\hline Craters of the Moon & $131 \pm 10$ & $132 \pm 6$ & $110 \pm 7$ & $133 \pm 10$ & $114 \pm 4$ & $109 \pm 4$ \\
\hline Idaho Falls & $127 \pm 6$ & $138 \pm 9$ & $116 \pm 4$ & $---\bar{c}$ & $120 \pm 5$ & $122 \pm 6$ \\
\hline Minidoka & $103 \pm 4$ & $129 \pm 6$ & 1 & $120 \pm 6$ & $105 \pm 2$ & $-e^{-}$ \\
\hline Rexburg & $113 \pm 5$ & $109 \pm 4$ & $107 \pm 4$ & $120 \pm 6$ & $109 \pm 3$ & $114 \pm 4$ \\
\hline Roberts & $137 \pm 8$ & $136 \pm 6$ & $\underline{124 \pm 4}$ & $138 \pm 4$ & $\underline{118 \pm 5}$ & $126 \pm 6$ \\
\hline $\operatorname{Mean}^{\mathrm{f}}$ & $\overline{123 \pm 11}$ & $\overline{128 \pm 11}$ & $\overline{111 \pm 9}$ & $\overline{126 \pm 3}$ & $\overline{113 \pm 5}$ & $\overline{117 \pm 7}$ \\
\hline \multicolumn{7}{|l|}{ Boundary Group: } \\
\hline Arco & $123 \pm 9$ & $134 \pm 6$ & $117 \pm 4$ & $127 \pm 6$ & $118 \pm 3$ & $121 \pm 7$ \\
\hline Atomic City & $117+9$ & $132 \pm 5$ & $125 \pm 4$ & $134 \pm 8$ & $124 \pm 5$ & $126 \pm 5$ \\
\hline Howe & $114 \pm 8$ & $126 \pm 4$ & $114 \pm 4$ & $121 \pm 4$ & $112 \pm 4$ & $108 \pm 4$ \\
\hline Monteview & $128 \pm 4$ & $120 \pm 5$ & $116 \pm 4$ & $120 \pm 7$ & $118 \pm 4$ & $120 \pm 6$ \\
\hline Mud Lake & $124 \pm 6$ & $138 \pm 4$ & $126 \pm 4$ & $130 \pm 8$ & $117 \pm 7$ & $--^{e}$ \\
\hline Reno Ranch & $120 \pm 8$ & $112 \pm 4$ & $107 \pm 4$ & $126 \pm 11$ & $\underline{113+4}$ & $\underline{117 \pm 8}$ \\
\hline Mean $^{\mathrm{f}}$ & $121 \pm 5$ & $\overline{127 \pm 10}$ & $118 \pm 7$ & $126 \pm 2$ & $117 \pm 5$ & $\overline{118 \pm 8}$ \\
\hline \multicolumn{7}{|c|}{$\begin{array}{l}\text { Annual exposure } \pm 2 \mathrm{~s} . \\
\text { Dosimeter missing at November } 1992 \text { collection time. } \\
\text { May to November dosimeter damaged. } \\
\text { Dosimeter missing at May and November } 1993 \text { collection times. } \\
\text { Dosimeter missing at November } 1994 \text { collection time. } \\
\text { Arithmetic mean with the } 95 \% \text { confidence interval for the mean. }\end{array}$} \\
\hline
\end{tabular}


LITCO. For purposes of comparison, annual exposures from 1991-94 are also included for each location.

The mean annual exposures for distant and boundary community locations in 1995 were $113 \pm 5 \mathrm{mR}$ and $117 \pm 5 \mathrm{mR}$, respectively, as measured by the Foundation's set of environmental dosimeters. The average exposure of the distant group is approximately equivalent to $116 \mathrm{mrem}$, when a dose equivalent conversion factor of 1.03 was used to convert from $\mathrm{mR}$ to $\mathrm{mrem}$ in tissue.

Table 4.12 summarizes the calculated effective dose equivalent an individual receives on the Snake River Plain from various background radiation sources. The terrestrial portion of this value, which is based on soil sampling for natural radionuclides in 1976, varies from year to year, depending on the amount of snow cover ${ }^{\mathrm{a}}$. For 1995, this resulted in about a 5\% dose reduction due to snow cover, which reached a maximum depth of $15 \mathrm{~cm}$ (6 in) during January.

The cosmic component varies primarily with altitude increasing from about 26 mrem at sea level to about $48 \mathrm{mrem}$ at the elevation of the INEL at approximately $1500 \mathrm{~m}(4900 \mathrm{ft} \text {.) })^{\mathrm{b}}$. The estimated sum of the terrestrial and cosmic components for 1995 is 118 mrem, nearly the same as the 116 mrem measured by TLDs at distant locations.

The component of natural background dose that varies the most is that of inhaled radionuclides. According to the National Council on Radiation Protection, the ma-

\footnotetext{
- National Council on Radiation Protection and Measurements, Ionizing Radiation Exposure of the Population of the United States, NCRP Report No. 93, September 1, 1987.

- National Council on Radiation Protection and Measurements, Exposure of the Population in the United States and Canada from Natural Background Radiation, NCRP Report No. 94, December 30, 1987.
}

TABLE 4.12

ESTIMATED NATURAL BACKGROUND EFFECTIVE DOSE EQUIVALENT (1995)

\begin{tabular}{|c|c|c|}
\hline \multirow{2}{*}{$\begin{array}{l}\text { Source of Radiation } \\
\text { Dose Equivalent }\end{array}$} & \multicolumn{2}{|c|}{$\begin{array}{c}\text { Total Average Annual Effective } \\
\text { Dose Equivalent (mrem) }\end{array}$} \\
\hline & Estimated & Measured (T்L) \\
\hline \multicolumn{3}{|l|}{ External } \\
\hline Terrestrial & 70 & ------- \\
\hline Cosmic & 48 & ------- \\
\hline Subtotal & 118 & 116 \\
\hline \multicolumn{3}{|l|}{ Internal } \\
\hline Cosmogenic & 1 & \\
\hline Inhaled radionuclides & 200 & \\
\hline${ }^{40} \mathrm{~K}$ and others & 39 & \\
\hline Subtotal & 240 & \\
\hline Total & 358 & \\
\hline
\end{tabular}

jor radionuclides contributing to this component are short-lived decay products of radon, and the amount of radon in buildings and ground water depends, in part, upon the natural radionuclide content of the soil and rock of the area. There is also variation between buildings of a given geographic area depending upon the materials each contains, the amount of ventilation and air movement, and other factors. The U.S. average of 200 mrem has been used in Table 4.12 for this component of the total background dose because no specific estimate for southeastern Idaho has been made, and few specific measurements have been made of radon in homes in this area. Therefore, the effective dose equivalent from natural background radiation for residents in the INEL vicinity may actually be higher or lower than the total estimated natural background dose of about 360 mrem shown in Table 4.12 and will vary from one location to another.

Annual exposure \pm two standard deviations (2s) for onsite TLDs representing the same 
Chapter 4: Environmental Radiological Program Information

exposure period as the offsite dosimeters are shown in Figures 4.7 through 4.16. Onsite dosimeters were placed on facility perimeters, concentrated in areas likely to show the highest gamma radiation readings. At TRA, for example, dosimeters \#3, \#4, and \#5 are adjacent to the former radioactive disposal pond which has been drained and covered by clean soil.
Other dosimeters (e.g., ICPP \#20 through \#22, TRA \#7 and \#8, and ANL-W \#15) are located in the vicinity of radioactive material storage areas. At some facilities, particularly ARA and ICPP, slightly elevated exposures result from soil contamination around the perimeter of these facilities. 


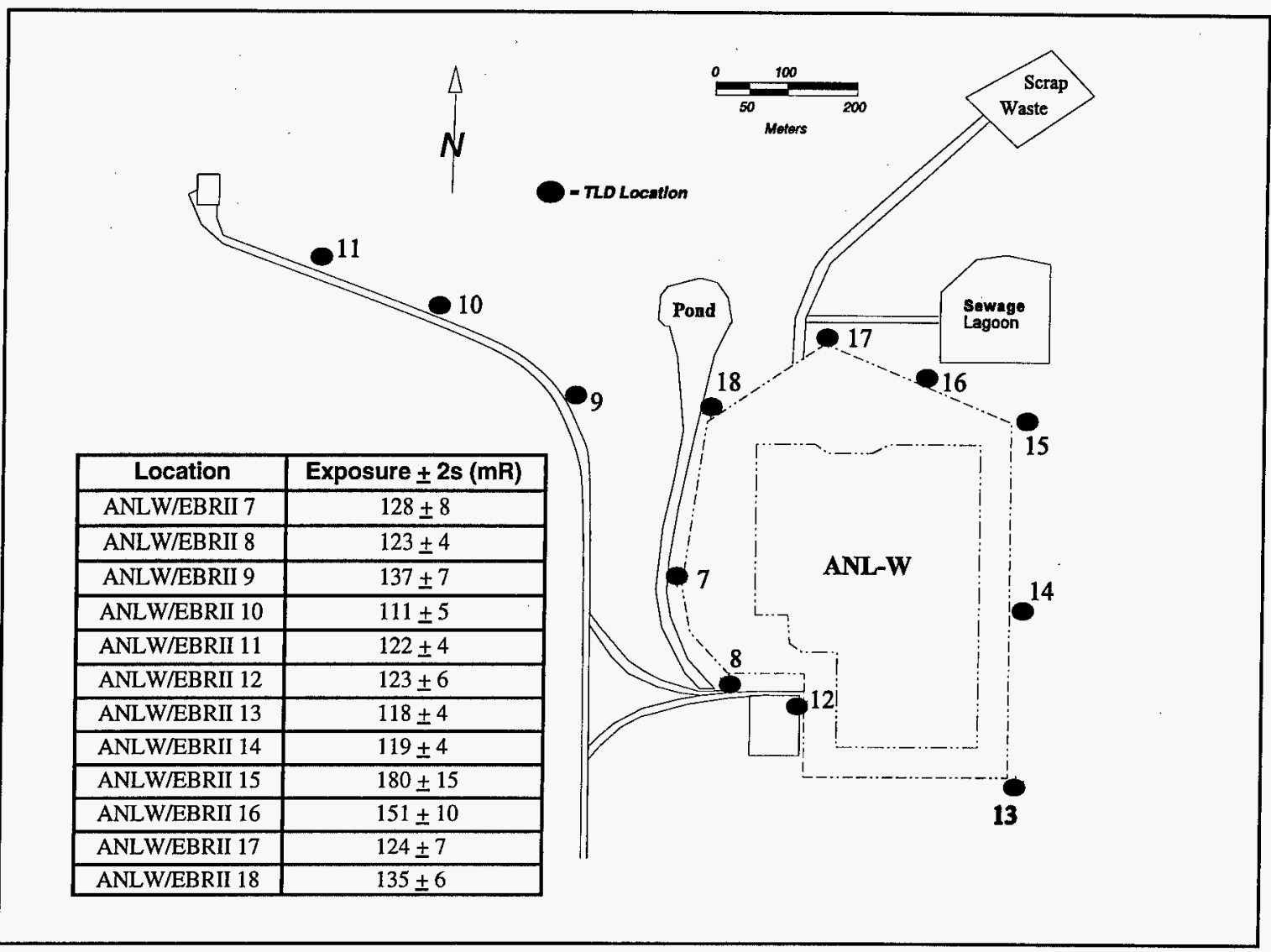

Figure 4.6 Environmental Dosimeter Measurements at ANL-W (1995)

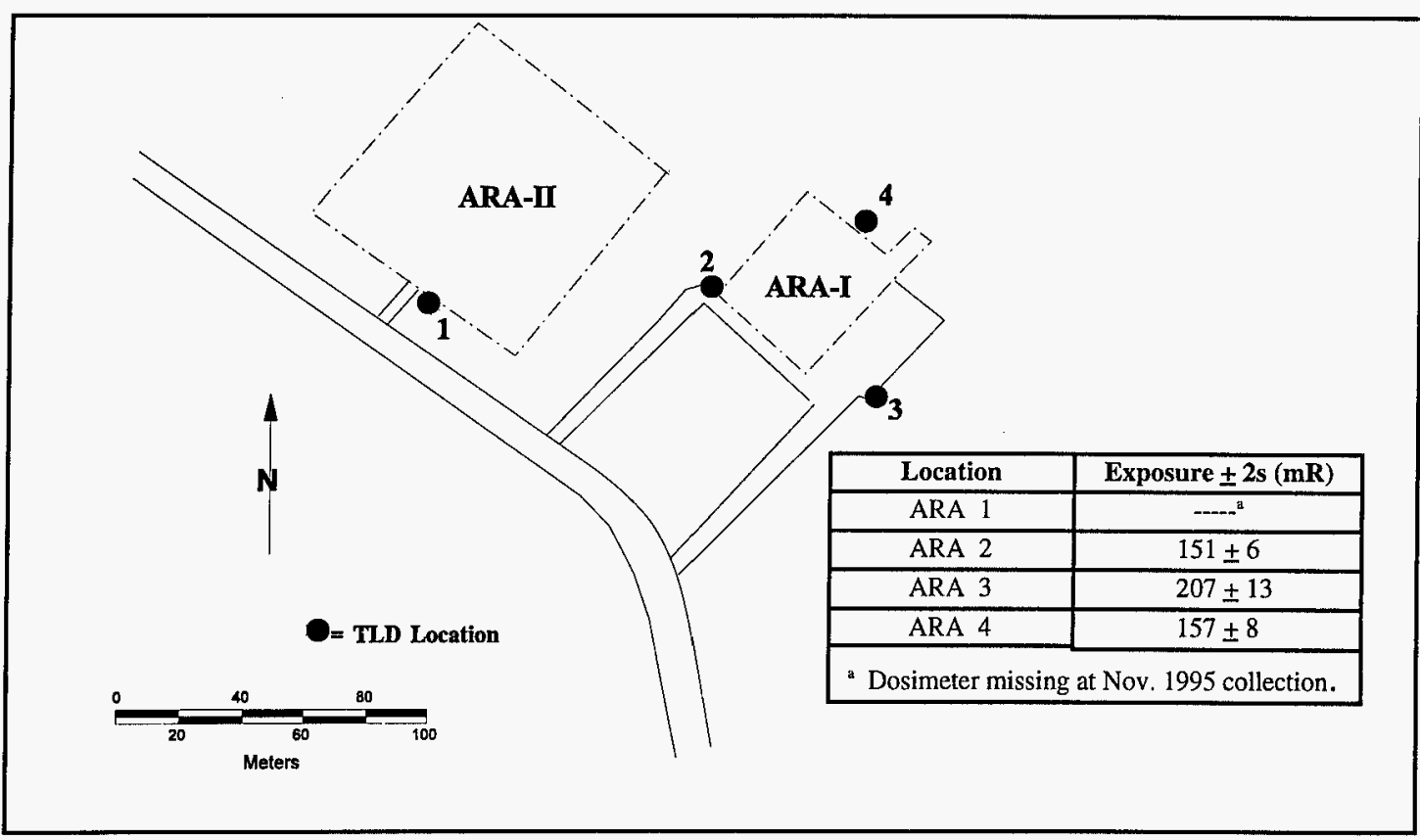

Figure 4.7 Environmental Dosimeter Measurements at ARA (1995) 
Chapter 4: Environmental Radiological Program Information

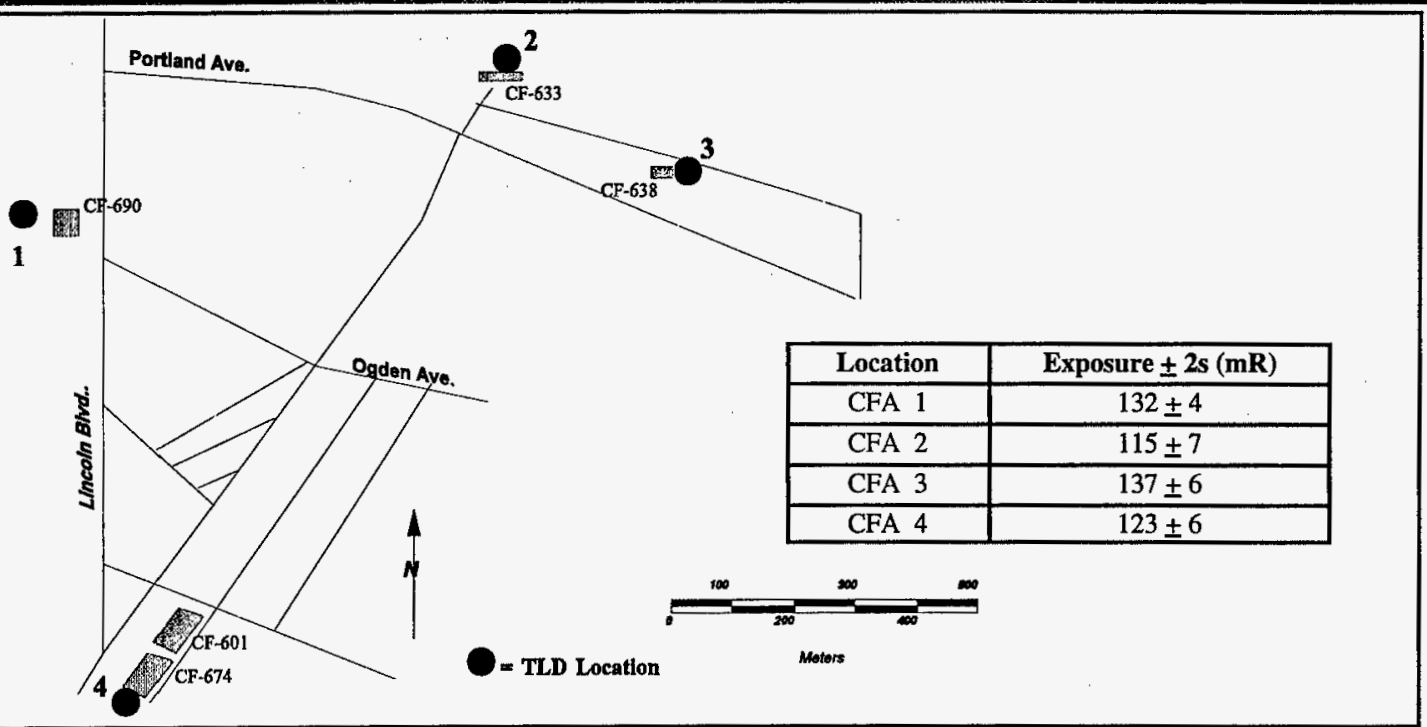

Figure 4.8 Environmental Dosimeter Measurements at CFA (1995)

\begin{tabular}{|c|c|}
\hline Location & Exposure \pm 2s (mR) \\
\hline ICPP 1 & $148 \pm 13$ \\
\hline ICPP 9 & - - $^{\mathrm{a}}$ \\
\hline ICPP 14 & $149 \pm 9$ \\
\hline ICPP 15 & $150 \pm 5$ \\
\hline ICPP 16 & $130 \pm 6$ \\
\hline ICPP 17 & $133 \pm 6$ \\
\hline ICPP 18 & $128 \pm 4$ \\
\hline ICPP 19 & $137 \pm 5$ \\
\hline ICPP 20 & $236 \pm 9$ \\
\hline ICPP 21 & $162 \pm 5$ \\
\hline ICPP 22 & $192 \pm 7$ \\
\hline ICPP 23 & $146 \pm 8$ \\
\hline ICPP 24 & $128 \pm 4$ \\
\hline ICPP 25 & $126 \pm 4$ \\
\hline ICPP 26 & $132 \pm 6$ \\
\hline Tree Farm 1 & $191 \pm 7$ \\
\hline Tree Farm 2 & $159 \pm 7$ \\
\hline Tree Farm 3 & $157 \pm 9$ \\
\hline Tree Farm 4 & $208 \pm 8$ \\
\hline${ }^{\mathrm{a}}$ Dosimeter missing at Nov. 1995 collection \\
\hline
\end{tabular}

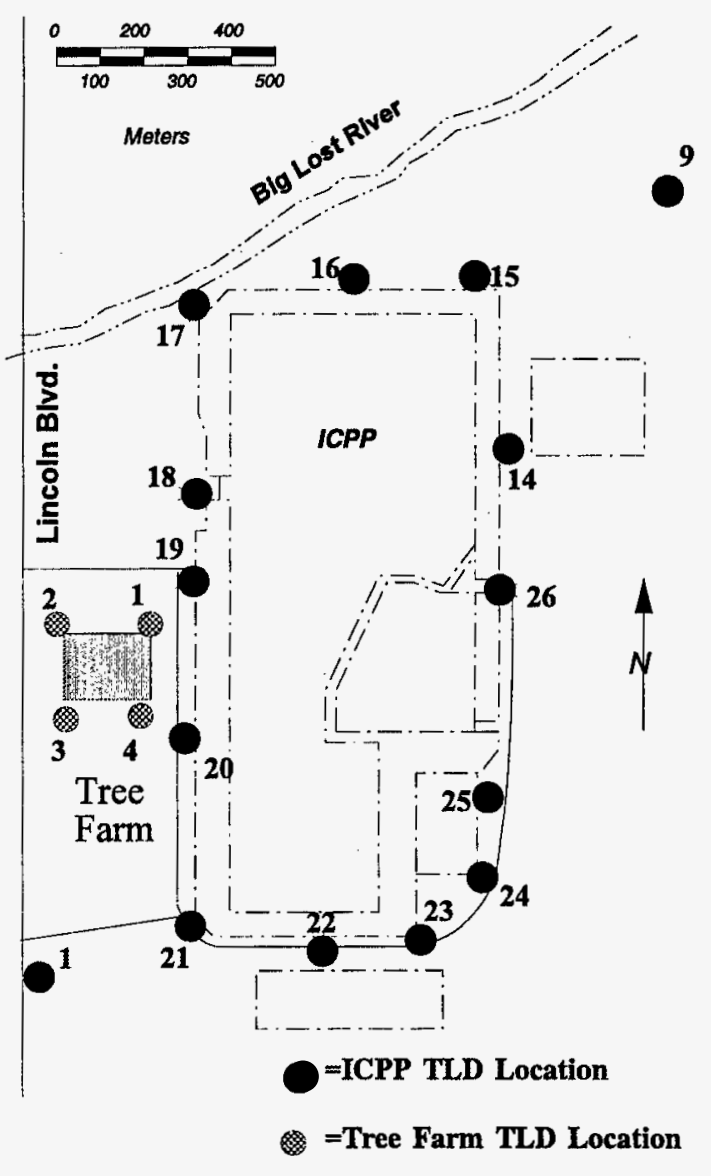

Figure 4.9 Environmental Dosimeter Measurements at ICPP (1995) 
1995 INEL Annual Site Environmental Report

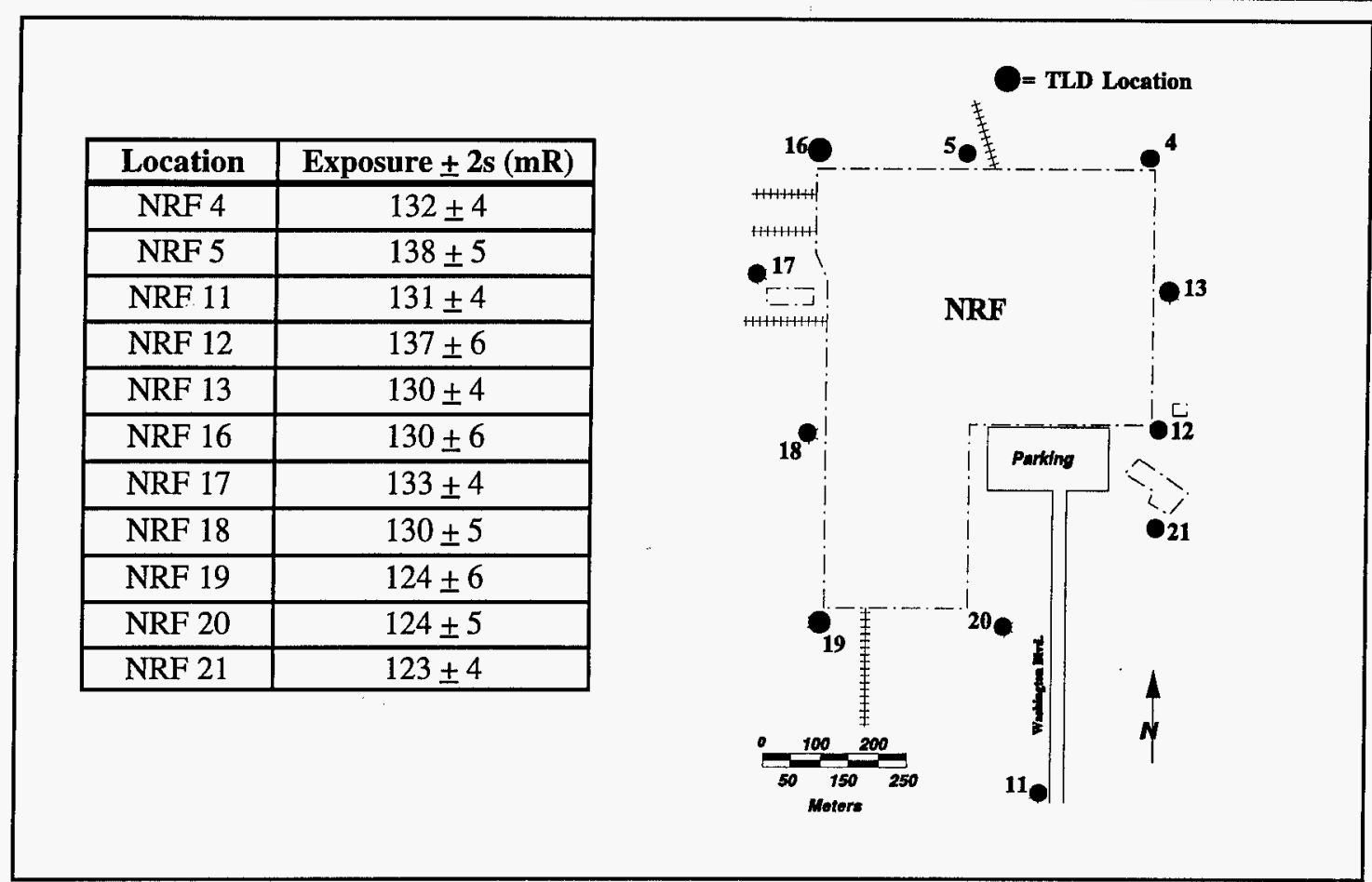

Figure 4.10 Environmental Dosimeter Measurements at NRF (1995)

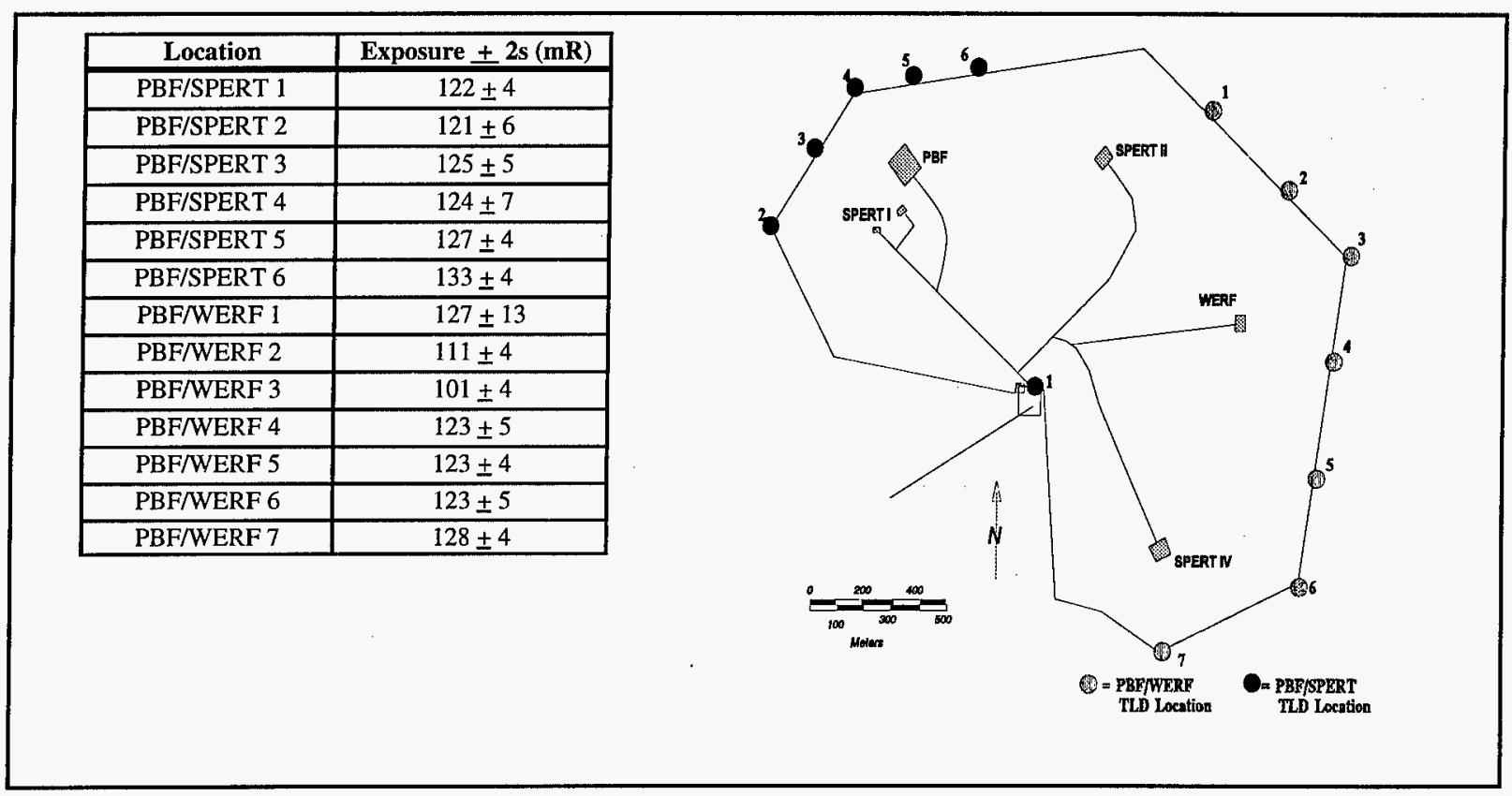

Figure 4.11 Environmental Dosimeter Measurements at PBF (1995) 


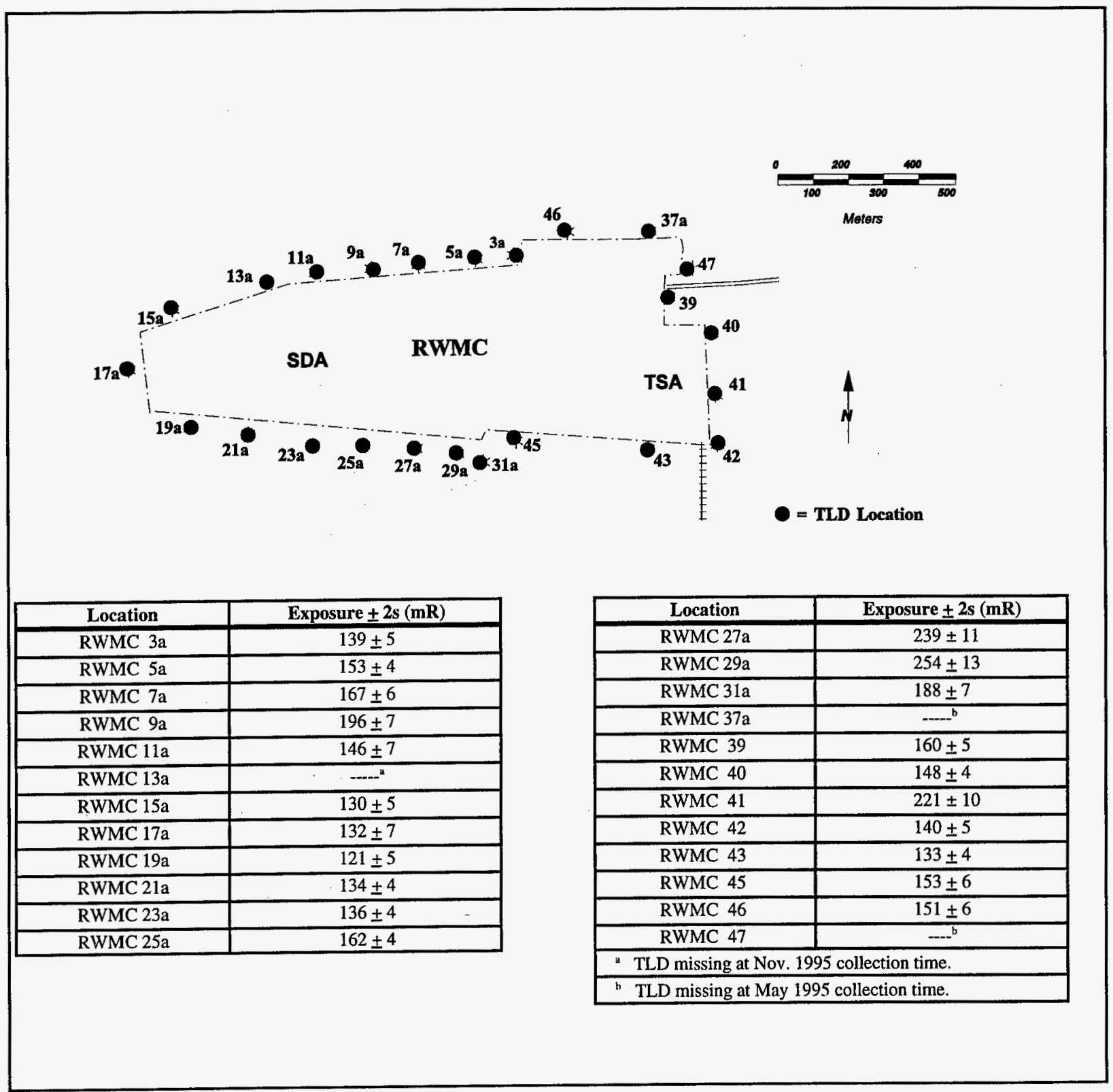

Figure 4.12 Environmental Dosimeter Measurements at RWMC (1995) 
1995 INEL Annual Site Environmental Report

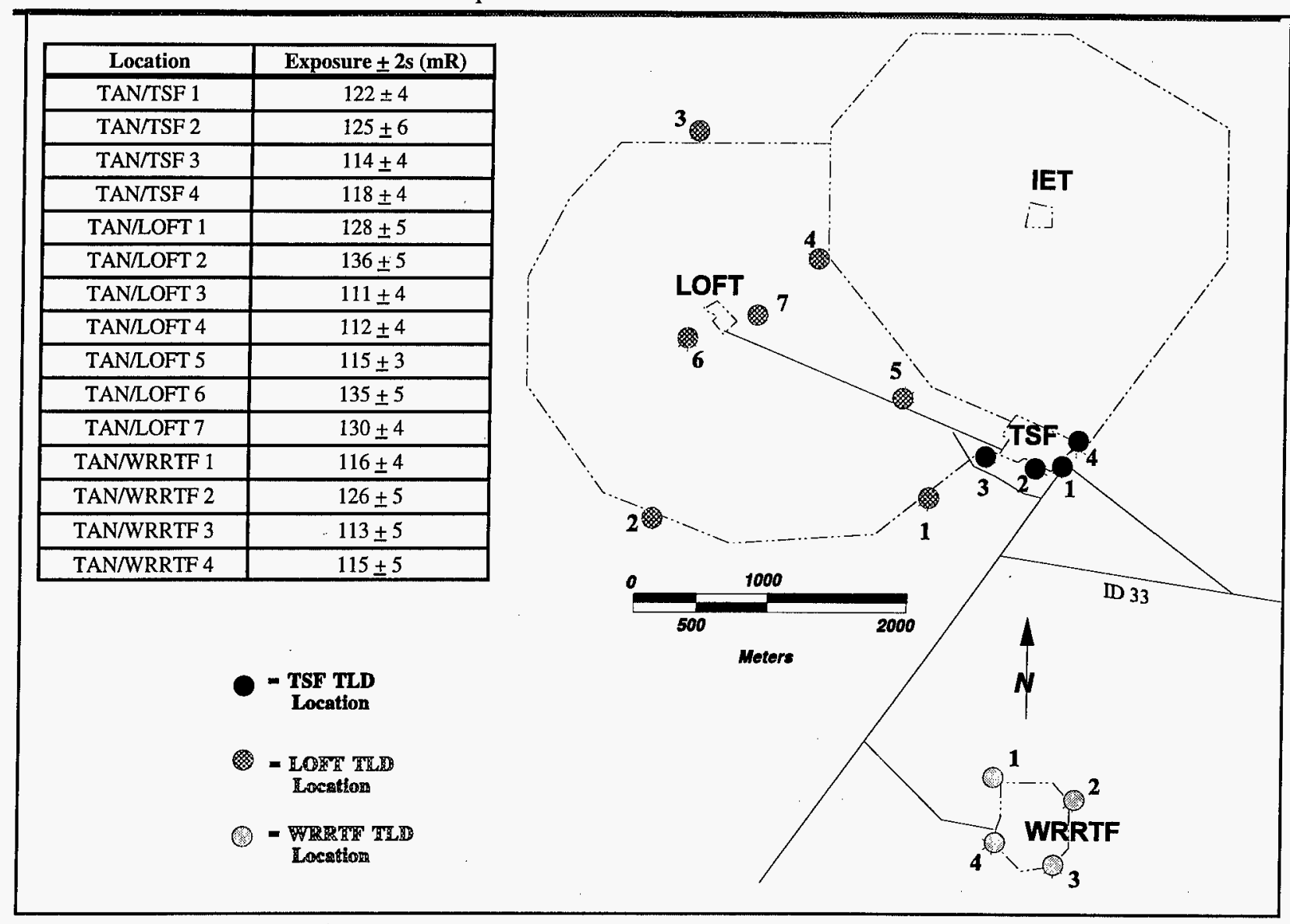

Figure 4.13 Environmental dosimeter measurements at TAN (1995)

\begin{tabular}{|c|c|}
\hline Location & Exposure $\pm \mathbf{2 s}(\mathbf{m R})$ \\
\hline TRA 1 & $149 \pm 6$ \\
\hline TRA 2 & $261 \pm 13$ \\
\hline TRA 3 & $295 \pm 11$ \\
\hline TRA 4 & $252 \pm 11$ \\
\hline TRA 5 & $178 \pm 5$ \\
\hline TRA 6 & $143 \pm 5$ \\
\hline TRA 7 & $166 \pm 6$ \\
\hline TRA 8 & $212 \pm 7$ \\
\hline TRA 9 & $149 \pm 6$ \\
\hline TRA 10 & $152 \pm 6$ \\
\hline TRA 11 & $151 \pm 4$ \\
\hline TRA 12 & $135 \pm 5$ \\
\hline TRA 13 & $139 \pm 6$ \\
\hline
\end{tabular}
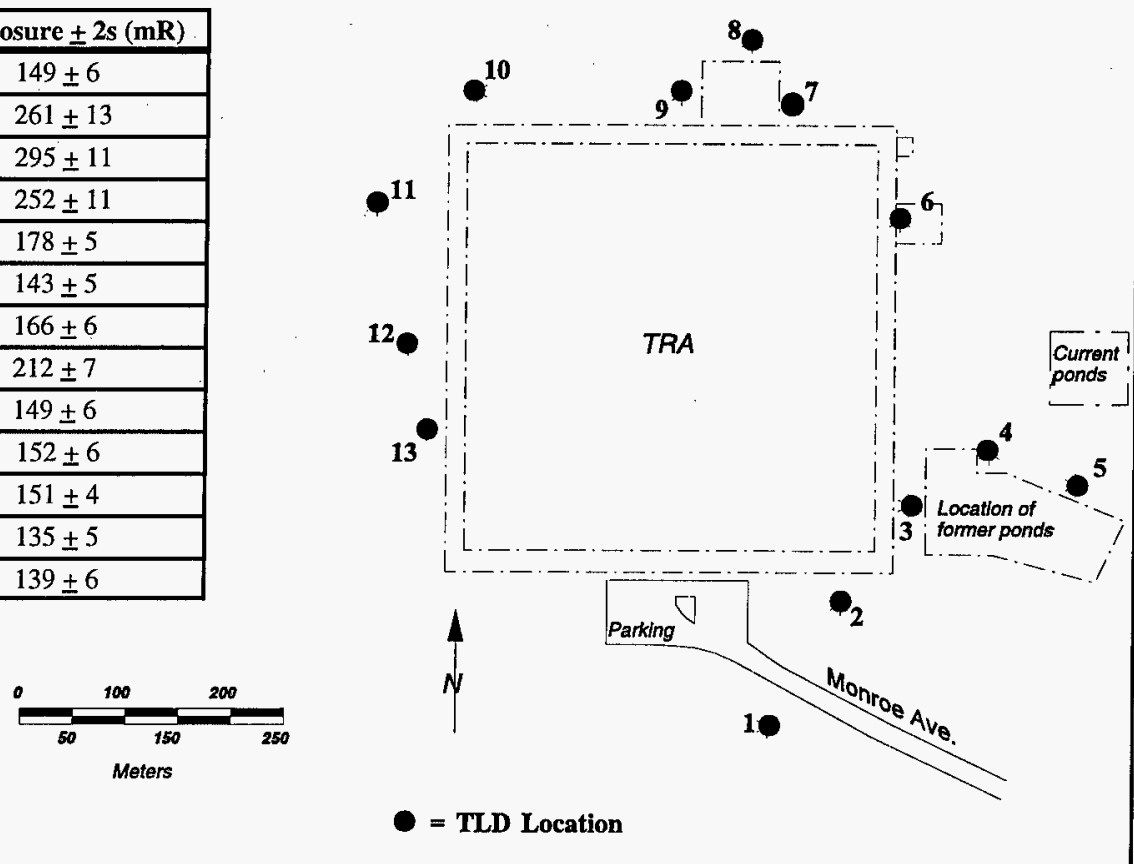


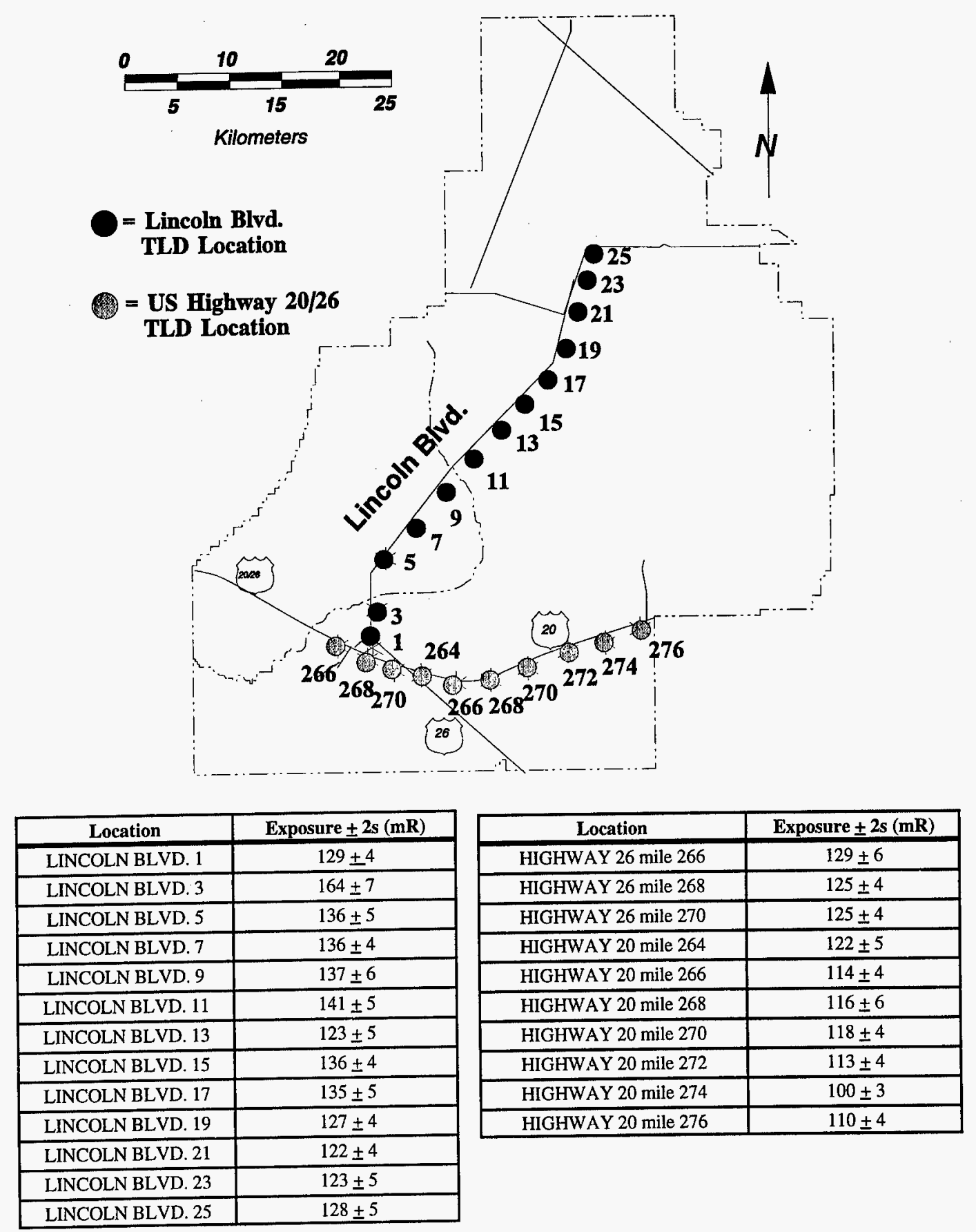

Figure 4.15 Environmental Dosimeter Measurements along Lincoln Blvd. and US Highways 20 and 26 (1995) 


\subsection{RADIOACTIVE EFFLUENT MONITORING}

\section{General}

Radionuclides in airborne and liquid effluents released to the environment were monitored at potentially significant release points. INEL contractors monitored these release points, including stacks and liquid effluent streams at facilities they operated, as required by state and federal regulations. These data were reported to LITCO's Radioactive Waste Management Information System, which publishes annual reports of the results of the effluent monitoring by month, facility, and radionuclide.

\section{Air}

An estimated total of $1,380 \mathrm{Ci}$ of radioactivity was released to the atmosphere from monitored sources at INEL facilities in 1995 (Table 4.13). More than 99\% of this total was in the form of noble gases. "The TRA facility was the source of nearly all of the radioactivity released to the atmosphere. Because of radioactive decay of the short-lived radionuclides, the actual activity that would reach offsite areas is less than the values indicated in the table.

The annual total airborne radioactive effluent varies from year to year, depending on which processes are active at INEL facilities. The total shown for 1995 is considerably less than the totals reported for the years 1987 through 1992. In those years, the actual amount of ${ }^{85} \mathrm{Kr}$ released from ICPP was classified information and an overestimated value was used. This was no longer the case beginning in 1993. Due to this overestimation of the ${ }^{85} \mathrm{Kr}$ release value, it is not possible to directly compare total amounts of radioactivity released to the air for years prior to 1993 . The $1,380 \mathrm{Ci}$ reported for 1995 was reduced from $2,300 \mathrm{Ci}$ reported for 1994 , and $2,800 \mathrm{Ci}$ reported for 1993.

\section{Liquid}

No liquids were released directly to the offsite environment from any INEL facility. Onsite releases are summarized in Table 4.14. Most liquid radioactive effluents were discharged into seepage ponds. At TRA, a new liquid effluent pond lined with hypalon plastic was constructed and placed in service in August 1993. This pond was used throughout 1995. There were no liquid releases from ANL-W since the EBR-II reactor was shut down during the year. At several other facilities, such as NRF, no radioactive liquids were released.

\subsection{EVALUATION OF POTENTIAL RADIATION DOSE TO THE PUBLIC}

\section{General Information}

Usually, the radiological impact of INEL operations on the resident public surrounding the INEL has been too small to be measured by the routine monitoring program. Therefore, the radiological impact of INEL operations by the air pathway has traditionally been estimated using the reported amounts of various radionuclides released during the year from Site facilities and appropriate air dispersion models, described in the next section, to estimate the concentrations of radionuclides at selected 
TABLE 4.13

RADIONUCLIDE COMPOSITION OF AIRBORNE EFFLUENTS (1995)

Airborne Effluent $(\mathbf{C i})^{\mathrm{a}}$

\begin{tabular}{|c|c|c|c|c|c|c|c|}
\hline $\begin{array}{c}\text { Effluent } \\
\text { Type }\end{array}$ & $\begin{array}{l}\text { Radio- } \\
\text { nuclide }\end{array}$ & Half-life & $\underline{\text { ANL-W }}$ & ICPP & NRF & TRA & Total $^{\mathbf{b}}$ \\
\hline \multirow{9}{*}{ Noble Gases } & ${ }^{41} \mathrm{Ar}$ & $1.83 \mathrm{~h}$ & 4.4 & - & $5.4 \times 10^{-2}$ & 1,310 & 1,310 \\
\hline & ${ }^{135} \mathrm{Xe}$ & $9.10 \mathrm{~h}$ & -- & -- & -- & 29 & 29 \\
\hline & ${ }^{88} \mathrm{Kr}$ & $2.84 \mathrm{~h}$ & -- & -- & -- & 8.5 & 8.5 \\
\hline & ${ }^{85} \mathrm{Kr}$ & $10.7 \mathrm{yr}$ & 6.1 & -- & $4.3 \times 10^{-1}$ & -- & 6.5 \\
\hline & ${ }^{133} \mathrm{Xe}$ & $5.25 \mathrm{~d}$ & -- & - & -- & 6.4 & 6.4 \\
\hline & ${ }^{85 \mathrm{~m}} \mathrm{Kr}$ & $4.48 \mathrm{~h}$ & -- & -- & -- & 5.1 & 5.1 \\
\hline & ${ }^{138} \mathrm{Xe}$ & $14.2 \mathrm{~min}$ & -- & - & -- & 3.2 & 3.2 \\
\hline & ${ }^{87} \mathrm{Kr}$ & $1.27 \mathrm{~h}$ & -- & -- & - & 2.9 & 2.9 \\
\hline & ${ }^{135 \mathrm{~m}} \mathrm{Xe}$ & $15.3 \mathrm{~min}$ & -- & - & -- & 1.5 & 1.5 \\
\hline \multirow{12}{*}{ Particulates } & ${ }^{88} \mathrm{Rb}$ & $15.4 \mathrm{~min}$ & -- & - & -- & 3.2 & 3.2 \\
\hline & ${ }^{138} \mathrm{Cs}$ & $32.2 \mathrm{~min}$ & -- & -- & -- & $1.7 \times 10^{-1}$ & $1.7 \times 10^{-1}$ \\
\hline & ${ }^{89} \mathrm{Rb}$ & $15.4 \mathrm{~min}$ & - & - & -- & $1.1 \times 10^{-2}$ & $1.1 \times 10^{-2}$ \\
\hline & ${ }^{99 \mathrm{~m}} \mathrm{Tc}$ & $6.01 \mathrm{~h}$ & -- & -- & -- & $2.0 \times 10^{-3}$ & $2.0 \times 10^{-3}$ \\
\hline & ${ }^{91 m} Y$ & $58.8 \mathrm{~d}$ & -- & -- & -- & $1.8 \times 10^{-3}$ & $1.8 \times 10^{-3}$ \\
\hline & ${ }^{139} \mathrm{Ba}$ & $1.39 \mathrm{~h}$ & -- & -- & -- & $1.3 \times 10^{-3}$ & $1.3 \times 10^{-3}$ \\
\hline & ${ }^{51} \mathrm{Cr}$ & $27.8 \mathrm{~d}$ & -- & -- & -- & $1.0 \times 10^{-3}$ & $1.0 \times 10^{-3}$ \\
\hline & ${ }^{137} \mathrm{Cs}$ & $30.2 \mathrm{yr}$ & -- & $2.9 \times 10^{-4}$ & - & $1.3 \times 10^{-5}$ & $3.0 \times 10^{-4}$ \\
\hline & ${ }^{90} \mathrm{Sr}+\mathrm{D}^{\mathrm{c}}$ & $28.6 \mathrm{yr}$ & -- & $4.5 \times 10^{-5}$ & -- & $2.2 \times 10^{-5}$ & $6.7 \times 10^{-5}$ \\
\hline & ${ }^{125} \mathrm{Sb}$ & $2.73 \mathrm{yr}$ & - & $5.0 \times 10^{-5}$ & - & -- & $5.0 \times 10^{-5}$ \\
\hline & ${ }^{238} \mathrm{Pu}$ & $87.7 \mathrm{yr}$ & -- & $9.5 \times 10^{-7}$ & -- & - & $9.5 \times 10^{-7}$ \\
\hline & ${ }^{239} \mathrm{Pu}$ & $2.4 \times 10^{4} \mathrm{yr}$ & -- & $1.6 \times 10^{-7}$ & - & -- & $1.6 \times 10^{-7}$ \\
\hline \multirow{8}{*}{$\begin{array}{l}\text { Tritium, }{ }^{14} \mathrm{C}, \\
\text { and Iodine } \\
\text { Isotopes }\end{array}$} & ${ }^{3} \mathrm{H}$ & $12.3 \mathrm{yr}$ & $5.2 \times 10^{-2}$ & 4.4 & $9.3 \times 10^{-2}$ & - & 4.6 \\
\hline & ${ }^{14} \mathrm{C}$ & $5,700 \mathrm{yr}$ & -- & $2.9 \times 10^{-2}$ & $7.7 \times 10^{-1}$ & -. & $8.0 \times 10^{-1}$ \\
\hline & ${ }^{129} \mathrm{I}$ & $1.6 \times 10^{7} \mathrm{yr}$ & -- & $9.6 \times 10^{-3}$ & - & -- & $9.6 \times 10^{-3}$ \\
\hline & ${ }^{134} \mathrm{I}$ & $52.6 \mathrm{~min}$ & -- & -- & -- & $3.2 \times 10^{-3}$ & $3.2 \times 10^{-3}$ \\
\hline & ${ }^{135} \mathrm{I}$ & $6.59 \mathrm{hr}$ & -- & -- & -- & $3.2 \times 10^{-3}$ & $3.2 \times 10^{-3}$ \\
\hline & ${ }^{132} \mathrm{I}$ & $83 \mathrm{~min}$ & -- & -- & -- & $2.6 \times 10^{-3}$ & $2.6 \times 10^{-3}$ \\
\hline & ${ }^{133} \mathrm{I}$ & $20.8 \mathrm{hr}$ & -- & -- & -- & $1.9 \times 10^{-3}$ & $1.9 \times 10^{-3}$ \\
\hline & ${ }^{131} \mathrm{I}$ & $8.04 \mathrm{~d}$ & -- & -- & $5.4 \times 10^{-6}$ & $6.0 \times 10^{-4}$ & $6.0 \times 10^{-4}$ \\
\hline \multicolumn{2}{|l|}{ All others } & - & $1.1 \times 10^{-2}$ & $5.1 \times 10^{-5}$ & $1.5 \times 10^{-5}$ & $2.5 \times 10^{-3}$ & $1.3 \times 10^{-2}$ \\
\hline & -- & 11 & 4.4 & 1.3 & 1,370 & 1,380 \\
\hline \multicolumn{8}{|c|}{$\begin{array}{l}\text { Preliminary radioactive release information provided by the } 1995 \text { Radioactive Waste Management Information System. The table } \\
\text { includes all radionuclides with total releases greater than } 1 \times 10^{-3} \mathrm{Ci}\left(1 \times 10^{-4} \text { for isotopes of iodine). Some radionuclides of special }\right. \\
\text { concern }\left({ }^{125} \mathrm{Sb} \text {, }{ }^{90} \mathrm{Sr} \text {, and Pu) are also included. Values are not corrected for decay after release. }\right. \\
\text { Rounded totals include small amounts from facilities not listed. } \\
\text { Parent-daughter equilibrium assumed. }\end{array}$} \\
\hline
\end{tabular}




\begin{tabular}{|c|c|c|c|c|}
\hline \multicolumn{5}{|c|}{$\begin{array}{c}\text { TABLE } 4.14 \\
\text { RADIONUCLIDE COMPOSITION OF LIQUI } \\
\text { RELEASED ONSITE (1995) }\end{array}$} \\
\hline \multirow[b]{2}{*}{ Radionuclide } & \multirow[b]{2}{*}{ Half-Life } & \multicolumn{3}{|c|}{ Liquid Effluent $(\mathbf{C i})^{a}$} \\
\hline & & ICPP & TRA & Total $^{\text {b }}$ \\
\hline${ }^{3} \mathrm{H}$ & $12.3 \mathrm{yr}$ & $8.7 \times 10^{-2}$ & 80 & 80 \\
\hline${ }^{51} \mathrm{Cr}$ & $27.8 \mathrm{~d}$ & -- & 2.6 & 2.6 \\
\hline${ }^{60} \mathrm{Co}$ & $5.27 \mathrm{yr}$ & $1.2 \times 10^{-4}$ & 0.25 & 0.26 \\
\hline${ }^{137} \mathrm{Cs}$ & $30.2 \mathrm{yr}$ & $7.1 \times 10^{-5}$ & $5.1 \times 10^{-2}$ & $5.1 \times 10^{-2}$ \\
\hline${ }^{65} \mathrm{Zn}$ & $243.8 \mathrm{~d}$ & -- & $3.9 \times 10^{-2}$ & $3.9 \times 10^{-2}$ \\
\hline${ }^{24} \mathrm{Na}$ & $15.0 \mathrm{yr}$ & -- & $3.6 \times 10^{-2}$ & $3.6 \times 10^{-2}$ \\
\hline${ }^{90} \mathrm{Sr}$ & $28.6 \mathrm{yr}$ & $1.6 \times 10^{-3}$ & $2.8 \times 10^{-2}$ & $2.9 \times 10^{-2}$ \\
\hline${ }^{181} \mathrm{Hf}$ & $42.4 \mathrm{~d}$ & -- & $1.8 \times 10^{-2}$ & $1.8 \times 10^{-2}$ \\
\hline${ }^{131} \mathrm{I}$ & $8.0 \mathrm{~d}$ & -- & $1.7 \times 10^{-2}$ & $1.7 \times 10^{-2}$ \\
\hline${ }^{89} \mathrm{Sr}$ & $50.5 \mathrm{~d}$ & -- & $1.5 \times 10^{-2}$ & $1.5 \times 10^{-2}$ \\
\hline${ }^{58} \mathrm{Co}$ & $70.9 \mathrm{~d}$ & -- & $1.3 \times 10^{-2}$ & $1.3 \times 10^{-2}$ \\
\hline All Others & -- & $1.1 \times 10^{-2}$ & 0.92 & 0.93 \\
\hline Grand Totals & -- & 0.10 & 84 & 84 \\
\hline $\begin{array}{l}\text { Preliminary radioact } \\
\text { includes all radionu } \\
\text { Rounded totals inclu }\end{array}$ & amoun & $\begin{array}{l}95 \text { Radioact } \\
\text { n } 1 \times 10^{-2} \mathrm{Ci} \\
\text { t listed. }\end{array}$ & $\begin{array}{l}\text { ent Inform } \\
\text { rrected for }\end{array}$ & \\
\hline
\end{tabular}

locations in the vicinity. During 1995, this was done for the radionuclides summarized in Table 4.13. The following were calculated: 1) the effective dose equivalent to the maximally exposed individual residing offsite using the EPA-required CAP-88 model; 2) the effective dose equivalent to the maximally exposed individual residing offsite using dispersion calculations from the MESODIF modela; and 3) the collective effective dose equivalent (population dose) within an $80-\mathrm{km}(50-\mathrm{mi})$ radius of the operations center of the Site (TRA and ICPP) using the MESODIF dispersion model.

For simplicity, the term dose will mean effective dose equivalent in the following dose assessment sections, unless another term is specifically stated. The dose was calculated by

2 G.E. Start and L.L. Wendell, Regional Effluent Dispersion Calculations Considering Spatial and Temporal Meteorological Variations; NOAA Technical Memorandum ERL ARL-44, May 1974. summing the committed dose equivalents to organs, each multiplied by a weighting factor that is proportional to the organ's radiosensitivity. The effective dose equivalent includes doses received from both external and internal sources and represents the same risk as if an individual's whole body were irradiated uniformly. DOE dose conversion factors and a 50yr integration period are used for internally deposited radionuclides ${ }^{b}$ and for radionuclides deposited on ground surfaces ${ }^{c}$ in calculations with both air dispersion models. Because the hypothetical effective dose equivalent to the maximally exposed individual residing near the INEL is so low, no allowance was made for shielding by housing materials or residence time in the community in any of the calculations

b U.S. Department of Energy, Intemal Dose Conversion Factors for Calculation of Dose to the Public, DOE/EH-0071, July 1988.

' U.S. Department of Energy, Extemal Dose Conversion Factors for Calculation of Dose to the Public, DOE/EH-0070, July 1988. 
using the MESODIF dispersion model. The CAP-88 code, which is used by all sites regardless of the magnitude of the hypothetical dose, does include a factor to allow for shielding and occupancy time.

The possible exposure pathways by which radioactive materials from Site operations could be transported to offsite environs were shown diagrammatically in Figure 3.1. Atmospheric transport is the principal potential exposure pathway from the INEL because radionuclides from the INEL have not been found in drinking water wells offsite. The air pathway is evaluated in the section "Maximum Individual Dose - Airborne Emissions Pathway."

Several indirect exposure pathways are being studied at the INEL to determine their effect, if any, on the highest possible dose that could have been received by a member of the public. The principal indirect exposure pathway involves eating game animals that have spent time on the INEL. Radioactivity present in game species depends upon the length of residence at each onsite location, the time elapsed since migration from the Site, and the metabolism of the animal. Estimates of the maximum potential dose to a person consuming meat from different game animals is described in the section "Maximum Individual DoseGame Ingestion Pathway."

\section{Maximum Individual Dose-Airborne Emissions Pathway}

CAP-88. During 1995, EPA regulations were in effect that limited the amount of airborne radionuclides released from any nuclear facility to that which will produce a dose of $10 \mathrm{mrem} / \mathrm{yr}$ to any member of the public. These regulations, known as the National Emission Standards for Hazardous Air Pollutants (NESHAPs), are found in 40 CFR Part 61 [Subpart H]. The EPA has specified that the CAP- 88 computer code be used to demonstrate compliance unless an alternate model has been approved by the Administrator of the EPA.

Because the INEL operations are spread over a wide area, the potential offsite doses occur at a variety of receptor (nearest resident, school, or business) locations. For the NESHAPs report, doses were evaluated for approximately 60 potential maximum receptor locations. The doses from all facilities were summed for each location. Using the CAP-88 code and INEL facility emissions, a 1995 hypothetical maximum dose of $0.018 \mathrm{mrem}$ $\left(1.8 \times 10^{-4} \mathrm{mSv}\right)$ was calculated for the Frenchman's Cabin area just south of the INEL's southern boundary. This is $0.18 \%$ of the EPA radiation protection standard. This area is not inhabited throughout the year but qualifies as a residence based on the definitions in NESHAPs. The largest contributor to the calculated dose at Frenchman's Cabin was diffuse sources of tritium at RWMC, accounting for $0.010 \mathrm{mrem}\left(1.0 \times 10^{-4} \mathrm{mSv}\right)$. A thorough discussion of the NESHAPs calculations appear in the 1995 INEL NESHAPs annual report that was submitted to the EPA prior to June 30, 1996.

MESODIF. The MESODIF air dispersion model has been used for over 20 years to calculate doses to members of the public residing near the INEL. The MESODIF diffusion curves, developed from tests in the desert environments at the INEL and Hanford facility in the state of Washington, may be more appropriate for the INEL than the EPArequired model. MESODIF uses a more complicated Gaussian puff model than the straight-line Gaussian plume model in CAP-88. The doses calculated with the MESODIF model are usually somewhat higher than doses using CAP-88. Differences between the two air dispersion models were discussed in detail in 
the 1986 annual report ${ }^{\mathrm{a}}$. The offsite concentrations calculated using both models were compared to actual monitoring results at offsite locations in 1986, 1987, and 1988. Concentrations calculated for several locations using the MESODIF model showed good agreement with concentrations from actual measurements, with the model generally predicting concentrations higher than those measured ${ }^{\mathrm{b}}$. The effective dose equivalent calculated using the MESODIF model is included in this report as well as the value calculated using the EPA-required CAP88 model.

The mesoscale map (Figure 4.16) shows the calculated 1995 concentrations normalized to a unit release rate for the INEL and vicinity. This map was prepared by NOAA's Air Resources Laboratory using the MESODIF model and data gathered continuously at meteorological stations on and around the Site. To make the display easier to read, the dispersion coefficient values are given in whole numbers and must be multiplied by $10^{-9} \mathrm{hr}^{2} / \mathrm{m}^{3}$. To obtain the average air concentration $\left(\mathrm{Ci} / \mathrm{m}^{3}\right)$ for a radionuclide released from TRA or ICPP along any dispersion coefficient isopleth (line of equal air concentration) in Figure 4.16, the value of the 1995 average dispersion coefficient (e.g., $30 \mathrm{x}$ $10^{-9} \mathrm{hr}^{2} / \mathrm{m}^{3}$ for the isopleth labeled 30 in Figure 4.16) is multiplied by the number of curies of the radionuclide released during 1995 and divided by the square of the number of hours in a year $\left(7.67 \times 10^{7}\right)$.

The MESODIF model predicts that the highest concentrations of radionuclides in the air at an inhabited area would have occurred

2 D. L. Hoff, E. W. Chew, and S. K. Rope, 1986 Environmental Monitoring Program Report for the Idaho National Engineering Laboratory Site, DOE/ID-12082(86), May 1987.

${ }^{b}$ E. W. Chew, R. G. Mitchell, 1987 EnvironmentalMonitoring Program Report for the Idaho National Engineering Laboratory Site, DOE/ID12082(87), May 1988. approximately $3 \mathrm{~km}(2 \mathrm{mi})$ south of Mud Lake, Idaho in 1995. The maximum hypothetical dose was calculated for an adult resident of that location from inhalation of air, submersion in air, ingestion of radioactivity on leafy vegetables, ingestion of milk, and exposure due to deposition of particulates on the ground surface. The calculation was based on data presented in Table 4.13 and Figure 4.16. Using a calculated value of $49 \times 10^{-9} \mathrm{hr}^{2} / \mathrm{m}^{3}$ (the largest dispersion coefficient value at a location that is inhabited by a full-time resident) and allowing for radioactive decay during the $53-\mathrm{km}(33-\mathrm{mi})$ transit of the radionuclides from the TRA/ICPP facilities to the Mud Lake location, the potential effective dose equivalent from all radionuclides released was calculated to be $0.008 \mathrm{mrem}$ $\left(8 \times 10^{-5} \mathrm{mSv}\right)$ (Table 4.15). This dose is $0.008 \%$ of the DOE radiation protection standard for a prolonged period of exposure to a member of the public from all pathways and $0.08 \%$ of the EPA standard for the airborne pathway only. Of the dose received, the ingestion pathway accounted for $55 \%$ of the total with immersion accounting for $40 \%$. Figure 4.17 illustrates the proportion of specific nuclides comprising the maximum individual dose for 1995. For comparison, the proportions of individual radionuclides contributing to the maximally exposed individual effective dose equivalents for 1991 through 1994 are also shown (Figure 4.18). The potential maximum individual doses for these years were 0.02 mrem, 0.004 mrem, $0.03 \mathrm{mrem}$, and 0.007 mrem. As discussed earlier, there are differences in the atmospheric dispersion portions of the MESODIF and CAP-88 air dispersion codes. The MESODIF code is the preferred code for comparing doses to most standards and 


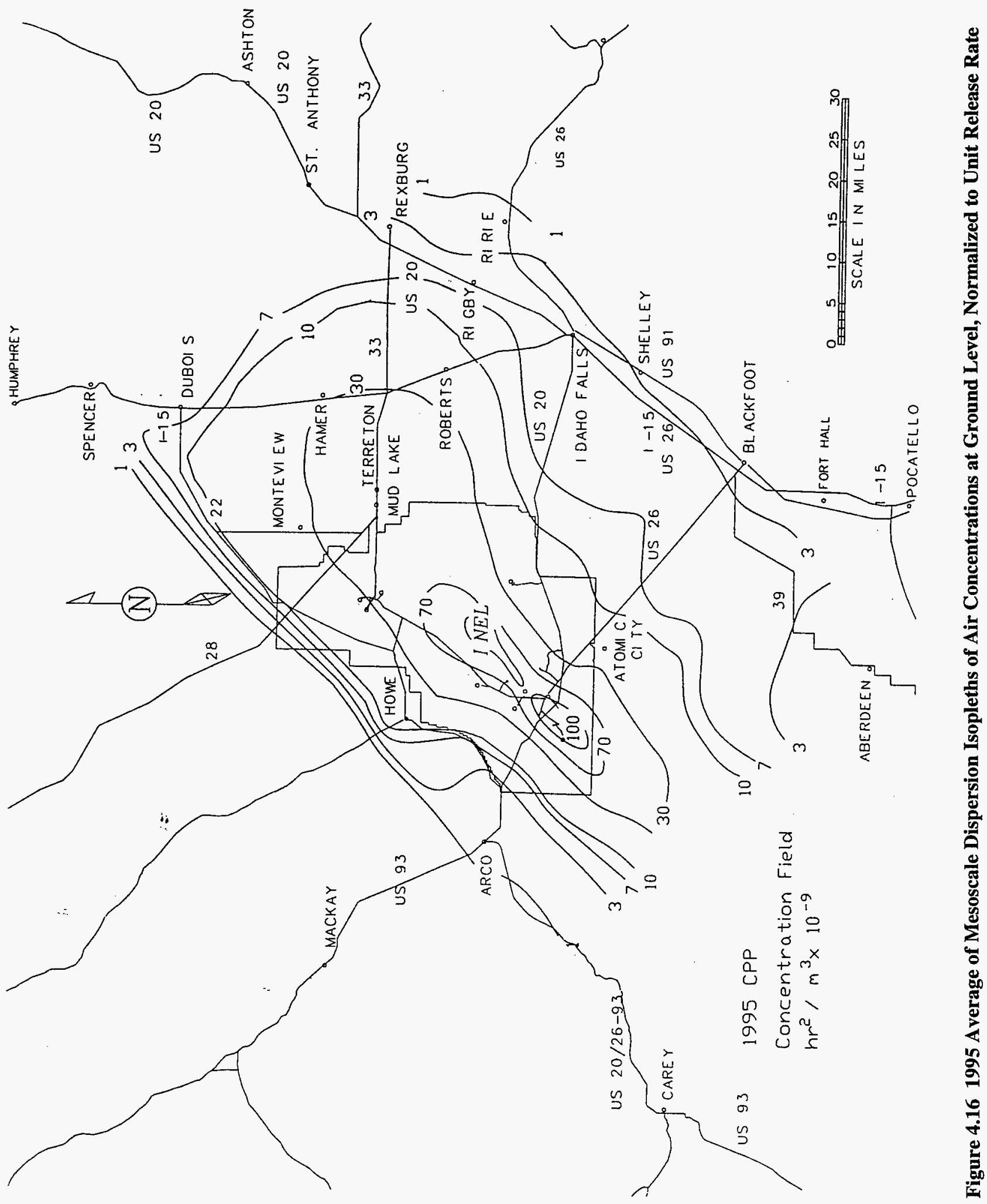




\begin{tabular}{|c|c|c|c|}
\hline \multicolumn{4}{|c|}{$\begin{array}{l}\text { TABLE } 4.15 \\
\text { MAXIMUM INDIVIDUAL EFFECTIVE DOSE EQUIVALENT (1995) }\end{array}$} \\
\hline \multirow[b]{2}{*}{$\underline{\text { Radionuclide }}^{\mathrm{a}}$} & \multirow{2}{*}{$\begin{array}{l}\text { Maximum Offsite } \\
\text { Concentration } \\
(\mu \mathrm{Ci} / \mathrm{mL})^{\mathrm{b}}\end{array}$} & \multicolumn{2}{|c|}{ Maximum Effective Dose Equivalent ${ }^{\mathrm{c}}$} \\
\hline & & mrem & $\underline{\mathbf{m S v}}$ \\
\hline$\overline{{ }^{41} \mathrm{Ar}}$ & $4.9 \times 10^{-13}$ & $3.2 \times 10^{-3}$ & $3.2 \times 10^{-5}$ \\
\hline${ }^{129} \mathrm{I}$ & $6.2 \times 10^{-20}$ & $3.9 \times 10^{-3}$ & $3.9 \times 10^{-5}$ \\
\hline${ }^{88} \mathrm{Kr}+\mathrm{D}$ & $8.2 \times 10^{-15}$ & $6.2 \times 10^{-5}$ & $6.2 \times 10^{-7}$ \\
\hline${ }^{135} \mathrm{Xe}$ & $1.7 \times 10^{-14}$ & $2.1 \times 10^{-5}$ & $2.1 \times 10^{-7}$ \\
\hline${ }^{90} \mathrm{Sr}+\mathrm{D}$ & $7.2 \times 10^{-19}$ & $1.3 \times 10^{-5}$ & $1.3 \times 10^{-7}$ \\
\hline${ }^{137} \mathrm{Cs}+\mathrm{D}$ & $3.8 \times 10^{-19}$ & $9.4 \times 10^{-6}$ & $9.4 \times 10^{-8}$ \\
\hline${ }^{60} \mathrm{Co}$ & $7.3 \times 10^{-20}$ & $7.2 \times 10^{-6}$ & $7.2 \times 10^{-8}$ \\
\hline${ }^{87} \mathrm{Kr}$ & $8.4 \times 10^{-16}$ & $3.7 \times 10^{-6}$ & $3.7 \times 10^{-8}$ \\
\hline${ }^{138} \mathrm{Xe}+\mathrm{D}$ & $2.5 \times 10^{-16}$ & $3.4 \times 10^{-6}$ & $3.4 \times 10^{-8}$ \\
\hline${ }^{131} \mathrm{I}$ & $3.9 \times 10^{-19}$ & $2.5 \times 10^{-6}$ & $2.5 \times 10^{-8}$ \\
\hline${ }^{85 \mathrm{~m}} \mathrm{Kr}$ & $2.6 \times 10^{-14}$ & $2.1 \times 10^{-6}$ & $2.1 \times 10^{-8}$ \\
\hline${ }^{3} \mathrm{H}$ & $2.9 \times 10^{-15}$ & $1.5 \times 10^{-6}$ & $1.5 \times 10^{-8}$ \\
\hline \multicolumn{4}{|c|}{$\begin{array}{l}\text { Table includes only radionuclides which contribute a dose of } 1.0 \times 10^{-6} \mathrm{mrem}\left(1 \times 10^{-8} \mathrm{mSV}\right) \text { or more. When indicated }(+\mathrm{D}) \text {, the } \\
\text { contribution of daughter decay products was also included in the dose calculations. } \\
\text { Estimate of radioactive decay using the distance to the Mud Lake area and the } 1995 \text { average wind speed in that direction. For } \\
\text { radionuclides where parent-daughter equilibria were used in dose calculations, concentration of the parent is shown. } \\
\text { Effective dose equivalent using dose conversion factors for submersion and deposition given in DOE/EH-0070 and dose } \\
\text { conversion factors for inhalation and ingestion given in DOE/EH-0071. }\end{array}$} \\
\hline
\end{tabular}

to calculated doses from previous years. The calculated maximum dose resulting from INEL operations is very small $(0.007 \%)$ compared to the measured 116 mrem average dose individuals in southeastern Idaho received from cosmic and terrestrial radiation during 1995 (from environmental dosimeter measurements - see Table 4.12). The calculated dose is even smaller compared to the total estimated effective dose equivalent from natural background radiation of about 360 mrem (see Table 4.12). For perspective, the calculated dose may also be compared to the approximately 30 mrem average dose received from medical diagnostic procedures, the 4 mrem average dose received from highway and road construction materials, and the 0.04 to 0.1 mrem received from luminous watches and clocks ${ }^{\mathrm{a}}$. Another source has estimated that the average five-hour jet flight contributes a dose of about 0.7 mrem to passengers, and that the average television viewer receives about 0.05 to 0.1 mrem annually ${ }^{\mathrm{b}}$.

\section{Maximum Individual Dose-Game Ingestion Pathway}

The potential dose to an individual from occasional ingestion of meat from game animals continues to be investigated at the INEL. One group of studies involves the

\footnotetext{
- National Council on Radiation Protection and Measurements, Ionizing Radiation Exposure of the Population of the United States, NCRP Report No. 93, September 1, 1987.

- United Nations Scientific Committee on the Effects of Atomic Radiation Sources and Biological Effects, United Nations: New York, 1982.
} 


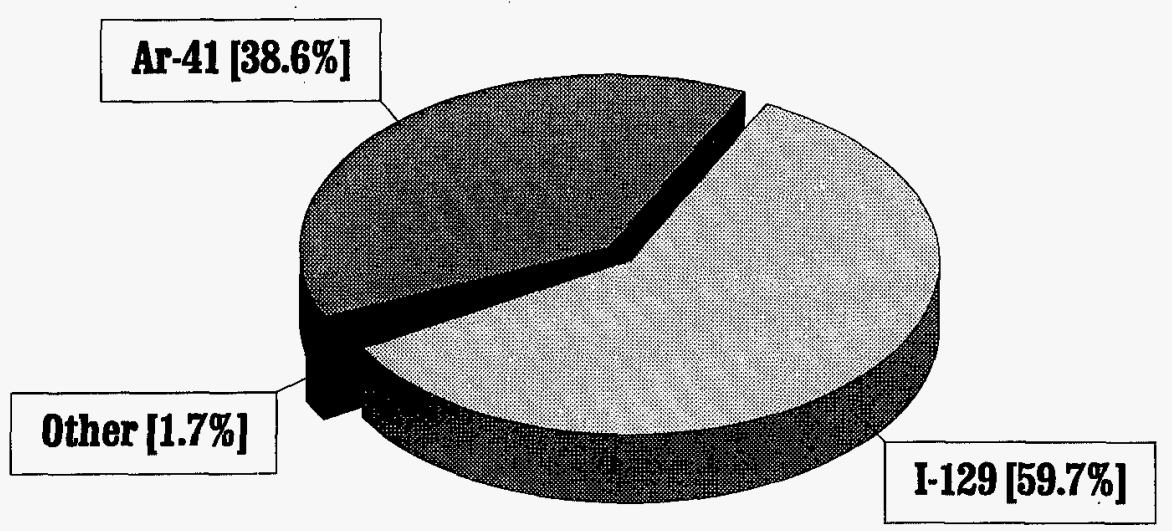

Figure 4.17 Radionuclides Contributing to Maximum Individual Dose (1995)

potential dose to individuals who might eat waterfowl that reside briefly at waste ponds used for the disposal of low-level liquid radioactive wastes. The Environmental Science and Research Foundation initiated a study in 1994 to obtain current data on these potential doses, following the construction of two hypalon-lined evaporation ponds at TRA and the closure of the percolation ponds formerly used for disposal of wastes at this facility.

During 1995, waterfowl were collected from ponds at TRA and ICPP that are currently used for the disposal of radioactive wastes, a pond at TAN that was previously used for low-level waste disposal, and from sewage lagoons at TRA and ANL-W that receive only nonradioactive waste. Control samples were also collected from the Fort Hall area. Radionuclide concentrations in the edible portion of the ducks, reported in Section 4.2 and Table 4.10, were used to estimate the potential dose to an individual consuming waterfowl from each facility (Table 4.16). The largest potential dose from the waterfowl at each facility came from the naturally occurring ${ }^{40} \mathrm{~K}$ in muscle tissue. Among the doses from manmade radionuclides, the highest values were found in the waterfowl collected at TAN $(0.018 \mathrm{mrem})$. The largest contributors to this dose were ${ }^{137} \mathrm{Cs}$ and ${ }^{95} \mathrm{Nb}$.

A negligible dose contribution came from ingestion of muscle tissue from waterfowl collected at TRA during 1995 . This may be due to a reduction in the quantity of radionuclides released to the pond, to the short time since the opening of the pond (and lack of time for radionuclide accumulation), or to the amount of time waterfowl spent on the pond. In any case, the potential doses from the current pond are substantially reduced from the 10 mrem dose estimated during a 1974 to 1978 study at the former TRA percolation 


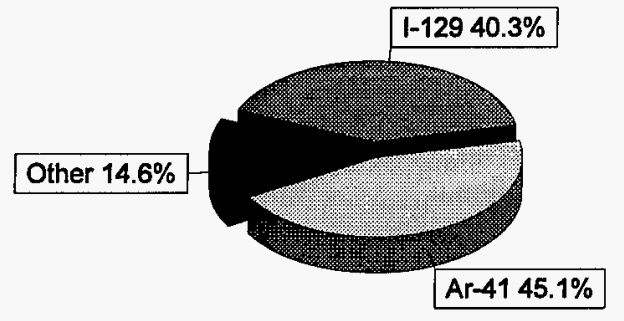

1991

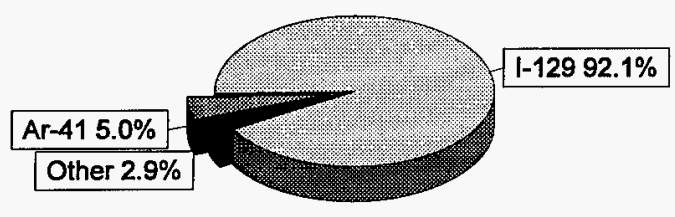

1993

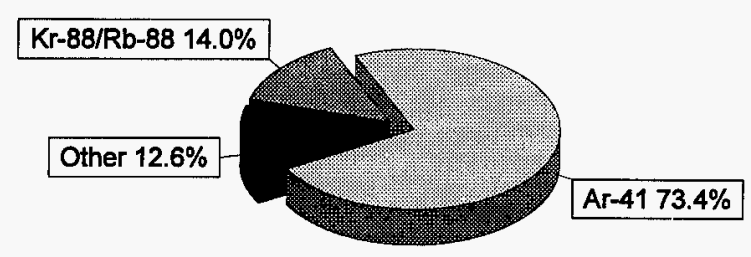

\section{2}

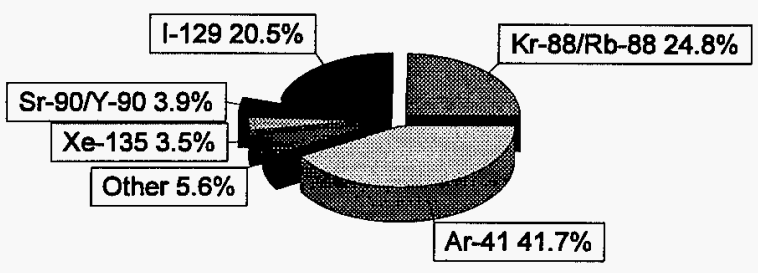

1994

\section{Figure 4.18 Radionuclides Contributing to Maximum Individual Dose (1991-1994)}

pond $\mathrm{d}^{\mathrm{a}}$, and from the 4.0 mrem estimated for the most contaminated duck taken from the percolation pond in 1984 to $1986^{\mathrm{b}}$.

\footnotetext{
a. K. Halford et al., "Radionuclide Concentrations in Waterfow! Using a Liquid Radioactive Disposal Area and the Potential Radiation Dose to Man," Health Physics, 40, February 1981, pp. 173-181.

b R.C. Morris, "The Implications of Lined Radioactive Waste Ponds for Waterfowl Contamination," in Environmental Health Physics: Proceedings of the Twenty-sixth Midyear Topical Meeting of the Health Physics Society, R.L. Kathren et al., eds., pp. 147-155.
}

Recent data (based on banding data from nearby wildlife refuges) suggest that a maximum of $7.2 \%$ of the waterfowl which visit the waste disposal ponds may potentially be harvested by Idaho hunters during the same yearc. According to a recent study of pond use by waterfowl, this would be about 42 ducks. Furthermore, estimated doses are based on the unlikely assumption that ducks are killed and

' Unpublished data from R.C. Morris. 
Chapter 4: Environmental Radiological Program Information

\begin{tabular}{|c|c|c|c|c|c|c|}
\hline \multicolumn{7}{|c|}{$\begin{array}{l}\text { TABLE } 4.16 \\
\text { INDIVIDUAL EFFECTIVE DOSE EQUIVALENTS FROM INGESTION OF MUSCLE } \\
\text { TISSUE OF WATERFOWL USING INEL WASTE DISPOSAL PONDS }{ }^{\mathrm{a}}\left(\mathrm{mrem} \times 1^{-2}\right)\end{array}$} \\
\hline \multirow{2}{*}{$\frac{\text { Radionuclide }}{{ }^{40} \mathrm{~K}^{\mathrm{b}}}$} & \multirow{2}{*}{$\begin{array}{c}\text { TRA } \\
\text { Evaporation } \\
\text { Pond } \\
1.7\end{array}$} & \multirow{2}{*}{$\begin{array}{l}\text { TRA } \\
\text { Sewage } \\
\text { Pond } \\
1.3\end{array}$} & \multirow{2}{*}{$\frac{\text { TAN }}{1.2}$} & \multirow{2}{*}{$\underline{\text { ICPP }}$} & \multirow{2}{*}{$\frac{\text { ANL-W }}{1.3}$} & $\begin{array}{c}\text { Background } \\
\text { (Ft. Hall) }\end{array}$ \\
\hline & & & & & & 1.4 \\
\hline${ }^{51} \mathrm{Cr}$ & 0.0 & 0.0 & $<0.01$ & 0.0 & 0.0 & $<0.01$ \\
\hline${ }^{54} \mathrm{Mn}$ & $<0.01$ & $<0.01$ & $<0.01$ & $<0.01$ & 0.0 & $<0.01$ \\
\hline${ }^{58} \mathrm{Co}$ & $<0.01$ & $<0.01$ & 0.0 & $<0.01$ & 0.0 & $<0.01$ \\
\hline${ }^{60} \mathrm{Co}$ & 0.017 & 0.0 & 0.0 & 0.020 & 0.0 & $<0.01$ \\
\hline${ }^{65} \mathrm{Zn}$ & 0.0 & 0.0 & 0.0 & 0.023 & 0.0 & $<0.01$ \\
\hline${ }^{95} \mathrm{Nb}$ & 0.0 & 0.0 & 0.62 & 0.29 & 0.0 & 0.0 \\
\hline${ }^{134} \mathrm{Cs}$ & 0.0 & 0.0 & 0.0 & 0.021 & 0.0 & 0.014 \\
\hline${ }^{137} \mathrm{Cs}$ & 0.0 & 0.0 & 1.1 & 0.22 & 0.024 & $<0.01$ \\
\hline${ }^{144} \mathrm{Ce}$ & 0.0 & 0.0 & 0.021 & 0.023 & 0.0 & $<0.01$ \\
\hline${ }^{181} \mathrm{Hf}$ & 0.0 & 0.0 & 0.0 & $<0.01$ & 0.0 & 0.023 \\
\hline Total & 1.7 & 1.3 & 3.0 & 1.7 & 1.3 & 1.4 \\
\hline$\left(\text { Total }-{ }^{40} \mathrm{~K}\right)^{\mathrm{C}}$ & $<0.05$ & $<0.05$ & 1.8 & 0.6 & $<0.05$ & $<0.05$ \\
\hline
\end{tabular}

eaten immediately after leaving the ponds. A lower dose would be more realistic due to biological elimination of the radioactivity. For example, the largest manmade contributor to the dose, ${ }^{137} \mathrm{Cs}$, has an effective half-life in mallard ducks of 11.2 days ${ }^{\mathrm{a}}$. This means that half of the ${ }^{137} \mathrm{Cs}$ present would be eliminated in 11.2 days. At the end of the next 11.2 days, half of the remaining radioactivity (or onefourth of the original activity) would be remaining.

\footnotetext{
" Halford, D.K., O.D. Markham, and G.C. White, "Biological Elimination of Radioisotopes by Mallards Contaminated at a Liquid Radioactive Waste Disposal Area, Health Physics, 45, pp 745-756.
}

A conservative (or high) estimate of the potential whole-body dose that could be received from an individual eating the entire muscle and liver mass of an antelope with the highest levels of radioactivity found in these animals was estimated at $0.2 \mathrm{mrem}$ in $1975^{\mathrm{b}}$. Game animals collected at the INEL during the past few years have shown much lower concentrations than in 1975. Based on the highest concentration of radionuclides found in a game animal during the past five years,

b O. D. Markham and D. K. Halford, "Effects of Decreased Effluents from Nuclear Fuel Reprocessing on Cs-137 Concentrations in Wildlife," Northwest Science, 59, 3, August 1985. 
the potential dose is now on the order of 0.03 mrem.

The highest estimated potential wholebody dose equivalent to a person eating the entire muscle mass of a mourning dove from the former TRA percolation pond was 0.3 mrem in $1974-77^{a}$. The potential dose for consumption of a sage grouse from the TRAICPP area was estimated at 2 mrem in 1977$80^{\mathrm{b}}$. Following the covering of the former percolation pond at TRA by clean soil, radionuclide concentrations in soil around that facility are substantially lower now than when the earlier studies took place. Therefore, the values for potential doses are likely much lower for sage grouse and doves, as the new study indicates for waterfowl. To obtain more recent data, doves and sage grouse will be collected in 1996 and 1997.

\section{0-Kilometer Population Dose}

An estimate was made of the collective effective dose equivalent (population dose) from inhalation, submersion, ingestion, and deposition that could have been received by all members of the public within an $80-\mathrm{km}$ (50-mi) radius of the TRA/ICPP facilities. This population dose (person-rem) was calculated by a computer program that multiplies the population number in each square mile by the dispersion coefficient at that point $\left(\mathrm{h}^{2} / \mathrm{m}^{3}\right)$ and the normalized dose received at the location of the maximally exposed individual

\footnotetext{
- O. D. Markham and D. K. Halford, "Radionuclides in Mourning Doves Near a Nuclear Facility Complex in Southeastern Idaho," The Wilson Bulletin, 94, 2, June 1982, pp. 185-195.

b J.W. Connelly and O. D. Markham, "Movements and Radionuclide Concentrations of Sage Grouse in Southeastern Idaho," Joumal of Wildlife Management, 47, 1, January 1983, pp. 169-175.
}

$\left(\mathrm{rem} / \text { year } / \mathrm{h}^{2} / \mathrm{m}^{3}\right)^{\mathrm{c}}$. The calculation overestimates dose, however, because the model (conservatively) does not account for radioactive decay of the isotopes during transport over distances greater than the $52 \mathrm{~km}(32 \mathrm{mi})$ from the TRA/ICPP facilities to the Mud Lake maximum location. Idaho Falls, for example, is about $66 \mathrm{~km}(41 \mathrm{mi})$ from TRA/ICPP. Neither residence time nor shielding by housing was considered when calculating the MESODIF dose upon which the collective dose is based. The calculation also tends to overestimate the population doses because they are, as noted above, extrapolated from the dose computed for the location of the potential maximally exposed individual. This individual is potentially exposed through ingestion of contaminated leafy vegetables from his garden and ingestion of milk from his cow grazing on contaminated pasture grass.

The 1995 MESODIF population dose within each census division was obtained by summing the results from appropriate areas contained within those divisions (Table 4.17). The total $80-\mathrm{km}(50-\mathrm{mi})$ population dose was the sum of population doses for the various census divisions. The estimated potential population dose was 0.08 person-rem $\left(8 \times 10^{-4}\right.$ person-Sv) to a population of about 121,500 . When compared with an approximate population dose of 42,500 person-rem (425 person-Sv) from natural background radiation, this represents an increase of only about $0.00019 \%$. The dose of 0.08 person-rem can also be compared to the following estimated population doses for the same size population: 3600 person-rem for medical diagnostic procedures, about 480 person-rem from exposure to highway and road construction

c D. L. Hoff, E. W. Chew, and S. K. Rope, 1986 Environmental Monitoring Program Report for the Idaho National Engineering Laboratory Site, DOE/ID-12082(86), May 1987. 
materials or 6 to 12 personrem for television viewing ${ }^{\mathrm{a}}$. The largest person-rem are found in the Idaho Falls and Hamer census divisions. For Idaho Falls this is due to the relatively high population; for Hamer this is because it lies in the predominant downwind direction from the INEL.

\section{Summary}

Table 4.18 summarizes the calculated annual effective dose equivalents from 1995 INEL operations using both the CAP-88 and MESODIF air dispersion models, and compares these doses to the EPA airborne pathway standard and to the estimated effective dose equivalent from natural background. The contribution of game animal consumption to the population dose has not been calculated because a small percentage of the population hunts game, few of the animals killed have spent time on the INEL, and most of the animals that do migrate from the INEL have background concentrations of radionuclides in their tissues. The total population dose con- tribution from these pathways would, realistically, be less than the sum of population doses from inhalation of air, submersion in air, and deposition on soil, which made up about five percent of the total dose to the maximally exposed individual.

- National Council on Radiation Protection and Measurements, Exposure of the Population in the United States and Canada from Natural Background Radiation, NCRP Report No. 94, December 30 , 1987. 
TABLE 4.18

SUMMARY OF ANNUAL EFFECTIVE DOSE EQUIVALENTS DUE TO INEL OPERATIONS (1995)

\begin{tabular}{|c|c|c|c|}
\hline & Maximum ] & an Individual ${ }^{a}$ & $\begin{array}{c}\text { Population } \\
\text { Dose }\end{array}$ \\
\hline & $\underline{\text { MESODIF }}^{\mathbf{b}}$ & $\underline{\text { CAP-88 }}$ & MESODIF \\
\hline Dose & $\begin{array}{c}0.008 \text { mrem } \\
\left(8 \times 10^{-5} \mathrm{mSv}\right)\end{array}$ & $\begin{array}{c}0.018 \mathrm{mrem} \\
\left(1.8 \times 10^{-4} \mathrm{mSv}\right)\end{array}$ & $\begin{array}{c}0.08 \text { person-rem } \\
\left(8 \times 10^{-4} \text { person- } S v\right)\end{array}$ \\
\hline Location & Mud Lake area & $\begin{array}{l}\text { Frenchman's Cabin } \\
\text { (south of the INEL) }\end{array}$ & $\begin{array}{c}\text { Area within an } 80- \\
\text { km circle }\end{array}$ \\
\hline $\begin{array}{l}\text { Applicable Radiation } \\
\text { Protection Standard }^{d}\end{array}$ & $\begin{array}{c}10 \mathrm{mrem} \\
(0.1 \mathrm{mSv})\end{array}$ & $\begin{array}{c}10 \mathrm{mrem} \\
(0.1 \mathrm{mSv})\end{array}$ & -..- \\
\hline Percentage of Standard & $0.08 \%$ & $0.018 \%$ & ---- \\
\hline Natural Background & $\begin{array}{l}360 \mathrm{mrem} \\
(3.6 \mathrm{mSv})\end{array}$ & $\begin{array}{l}360 \mathrm{mrem} \\
(3.6 \mathrm{mSv})\end{array}$ & $\begin{array}{c}\text { 43,700 person-rem } \\
\text { (437 person-Sv) }\end{array}$ \\
\hline $\begin{array}{c}\text { Percentage of } \\
\text { Background }\end{array}$ & $0.002 \%$ & $0.005 \%$ & $0.00018 \%$ \\
\hline $\begin{array}{l}\text { Hypothetical dose to the ma } \\
\text { Effective dose equivalent ca } \\
\text { time or shielding by buildin } \\
\text { Effective dose equivalent ca } \\
\text { Although the DOE standard } \\
\text { facilities will comply with }\end{array}$ & $\begin{array}{l}\text { exposed individual res } \\
\text { using the MESODIF } \\
\text { using the CAP- } 88 \text { cod } \\
\text { xposure models is } 10 \\
\text { tandard for the airbor }\end{array}$ & $\begin{array}{l}\text { INEL. } \\
\text { given in DOE Order } 5400 \text {. MESODIF calcu } \\
\text { of } 10 \mathrm{mrem} / \mathrm{y} \text {. }\end{array}$ & $\begin{array}{l}\text { not consider occupancy } \\
\text { zuidance states that DOE }\end{array}$ \\
\hline
\end{tabular}




\section{Chapter 5. GROUND WATER}

\section{Chapter Summary}

The Snake River Plain Aquifer, a primary source for drinking water and crop irrigation for southeastern Idaho, flows beneath the Idaho National Engineering Laboratory (INEL). The U.S. Geological Survey (USGS) maintains 125 observation wells in the INEL vicinity to monitor the movement of radiological and nonradiological substances in the Snake River Plain Aquifer, perched aquifers, and surface water bodies (Section 5.1). In addition to routine monitoring, the USGS publishes the results of a variety of special studies detailing conditions in the aquifer. Documents that were issued during 1995 ancluded reports on long-term studies of the aquifer, both on the INEL and in the region between the INEL and the Hagerman area; a report on the water quality in the vicinity of the Naval Reactors Facility; and two reports detailing the stratigraphy and geochemistry of the rocks that make up the aquifer. These reports are summarized in this chapter.

Contractors who operate the various facilities at the INEL also perform routine monitoring of ground water (Section 5.2). Monitoring conducted during 1995, and summarized in this chapter included bacteriological monitoring, radiological monitoring, and chemical monitoring for organic substances, metals, and other constituents.
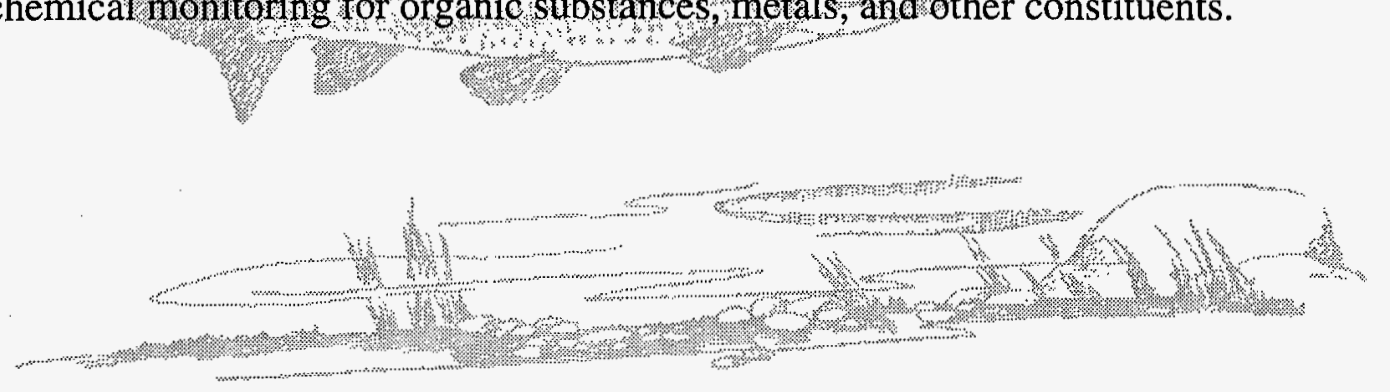


\section{GROUND WATER}

\subsection{USGS PROGRAM INFORMATION}

\section{USGS Program Description}

No streams or rivers flow from within the INEL to locations outside the boundaries. Water monitoring conducted in 1995 included onsite and offsite ground-water monitoring, plus samples from the Snake River and other surface streams and tributaries in the INEL vicinity, some of which flow onto the Site and sink into its porous soils. A brief description of the hydrogeology of the INEL and the movement of water in the Snake River Plain Aquifer was given in Chapter 1. Further information may be found in USGS publications.

The Snake River Plain Aquifer, which lies beneath the INEL, serves as one of the primary sources for drinking water and crop irrigation in the Snake River Basin. The USGS has investigated hydrologic conditions at the INEL since the Site's origination, and currently conducts an extensive monitoring program for the aquifer and perched water bodies above it. This program includes collection of samples on the INEL and at locations beyond the southern and western boundaries.

The USGS maintains 125 aquifer observation wells on or near the INEL. Additionally, 45 wells are available for sampling perched ground-water bodies. In addition, more than 120 auger holes have been drilled to monitor shallow perched groundwater bodies (Figures 5.1 and 5.2). USGS monitors water levels in wells, and radiological and nonradiological substances in water from their observation wells and auger holes. Various USGS reports, available from the USGS INEL Project Office, contain maps showing the frequency of water level measurements and water sample collections. Recent information has also been published on the shape and extent of waste plumes (i.e., the spread of various contaminants in the water of the aquifer and perched water from INEL facilities) as they were between 1989 and $1991^{\mathrm{a}}$. Figures 5.3 and 5.4 show plumes for tritium and ${ }^{90} \mathrm{Sr}$ as they existed in 1991 based on the most recent published data.

The USGS routine ground-water surveillance program was summarized in Chapter 3, "Environmental Program Information." In 1995 , the routine program included collection of 400 samples for radionuclides and inorganic constituents including trace elements, and 65 samples for purgeable organic compounds.

The USGS also conducts special studies of the ground water of the Snake River Plain. A summary of these studies is provided in the next subsection of this report. These special studies provide more specific geological and hydrological information on the flow and recharge of the aquifer and the movements of radioactive and nonradioactive substances in the ground water. Most of the information from these studies is published in USGS reports.

Results of recently published monitoring or surveillance activities are summarized in the Annual Site Environmental Report during the year of publication, but may refer to sampling programs that took place in earlier years. USGS results and information for securing copies of their reports are available upon request from the USGS INEL Project Office.

a R. C. Bartholomay, B. R. Orr, M. J. Liszewski, and R. G. Jensen, Hydrologic Conditions and Distribution of Selected Radiochemical and Chemica/ Constituents in Water, Snake River Plain Aquifer, Idaho National Engineering Laboratory, Idaho, 1989 through 1991, U.S. Geological Survey, Water-Resources Investigation Report 95-4175, DOE/ID-22123, August 1995. 


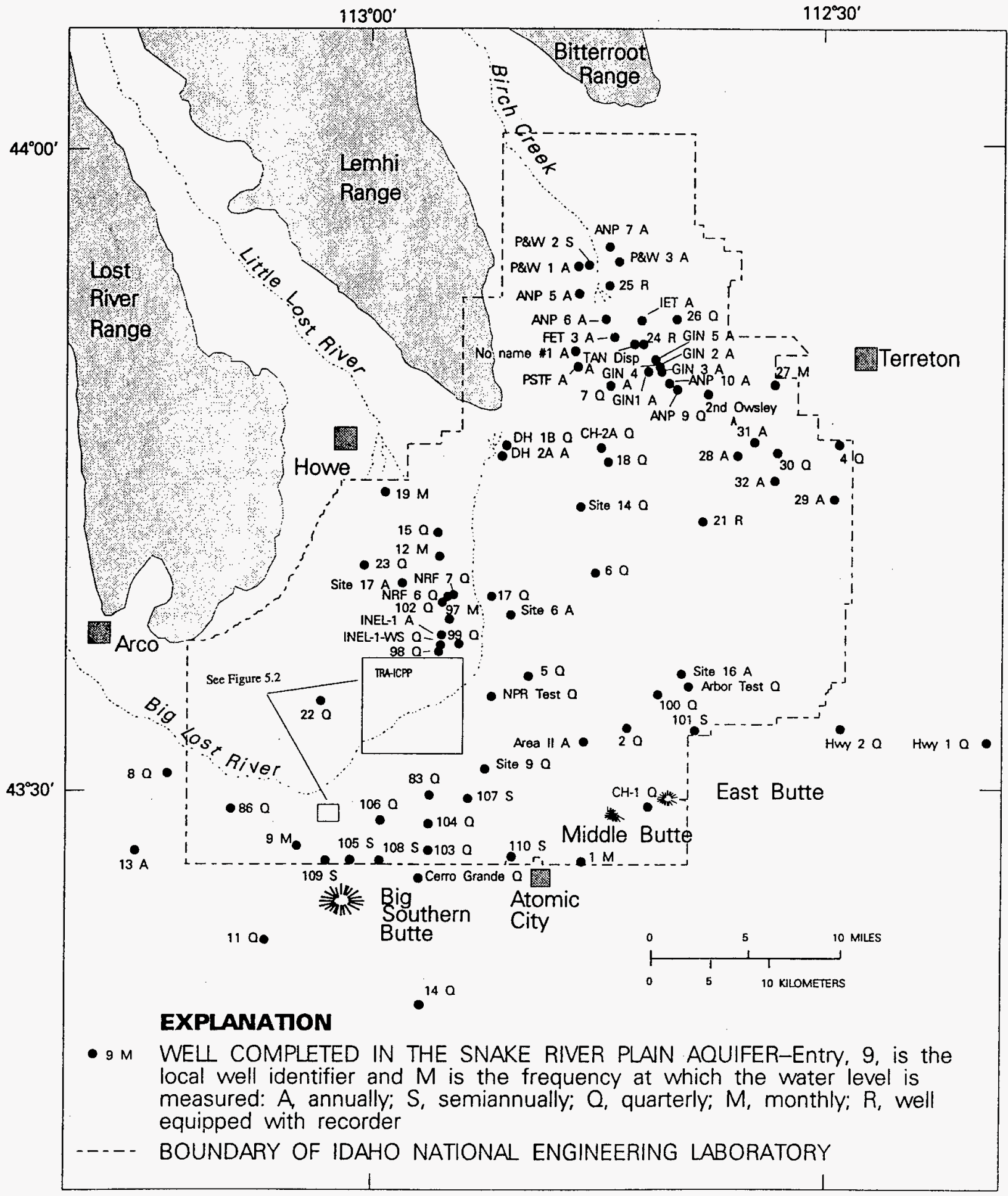

\section{Figure 5.1 USGS Well Locations}



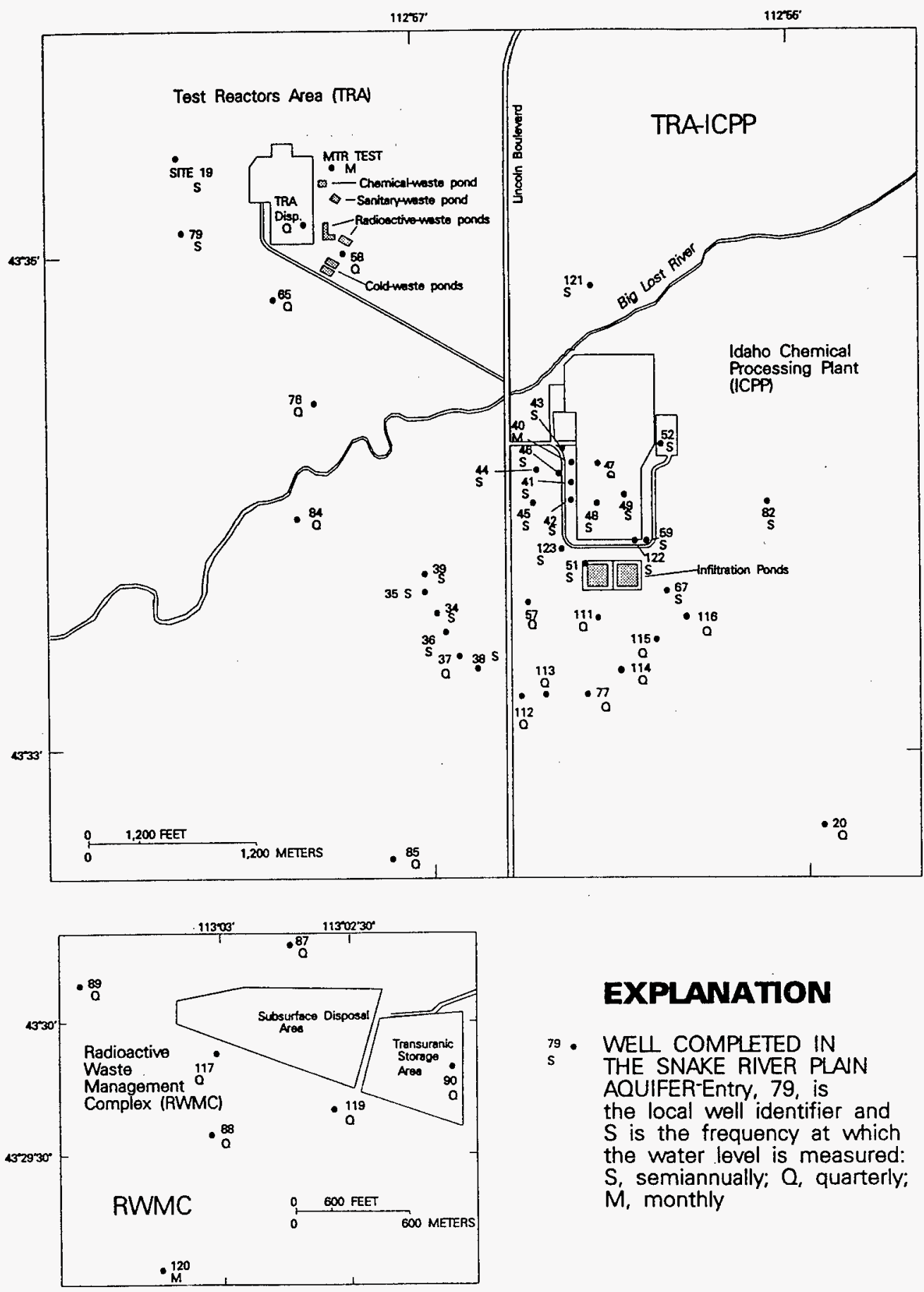

\section{EXPLANATION}

79 - WEU COMPLETED IN

THE SNAKE RIVER PLAIN

AQUIFER-Entry, 79, is

the local well identifier and

$S$ is the frequency at which

the water level is measured:

$S$, semiannually; $Q$, quarterly;

$M$, monthly

Figure 5.2 USGS well locations at ICPP-TRA and RWMC 


\section{EXPLANATION}

LINE OF EQUAL TRITIUM CONCENTRATION Interval variable; concentration in picocuries per milliliter

WELL COMPLETED IN THE SNAKE RIVER PLAIN AQUIFER AND SAMPLED FOR TRITIUM

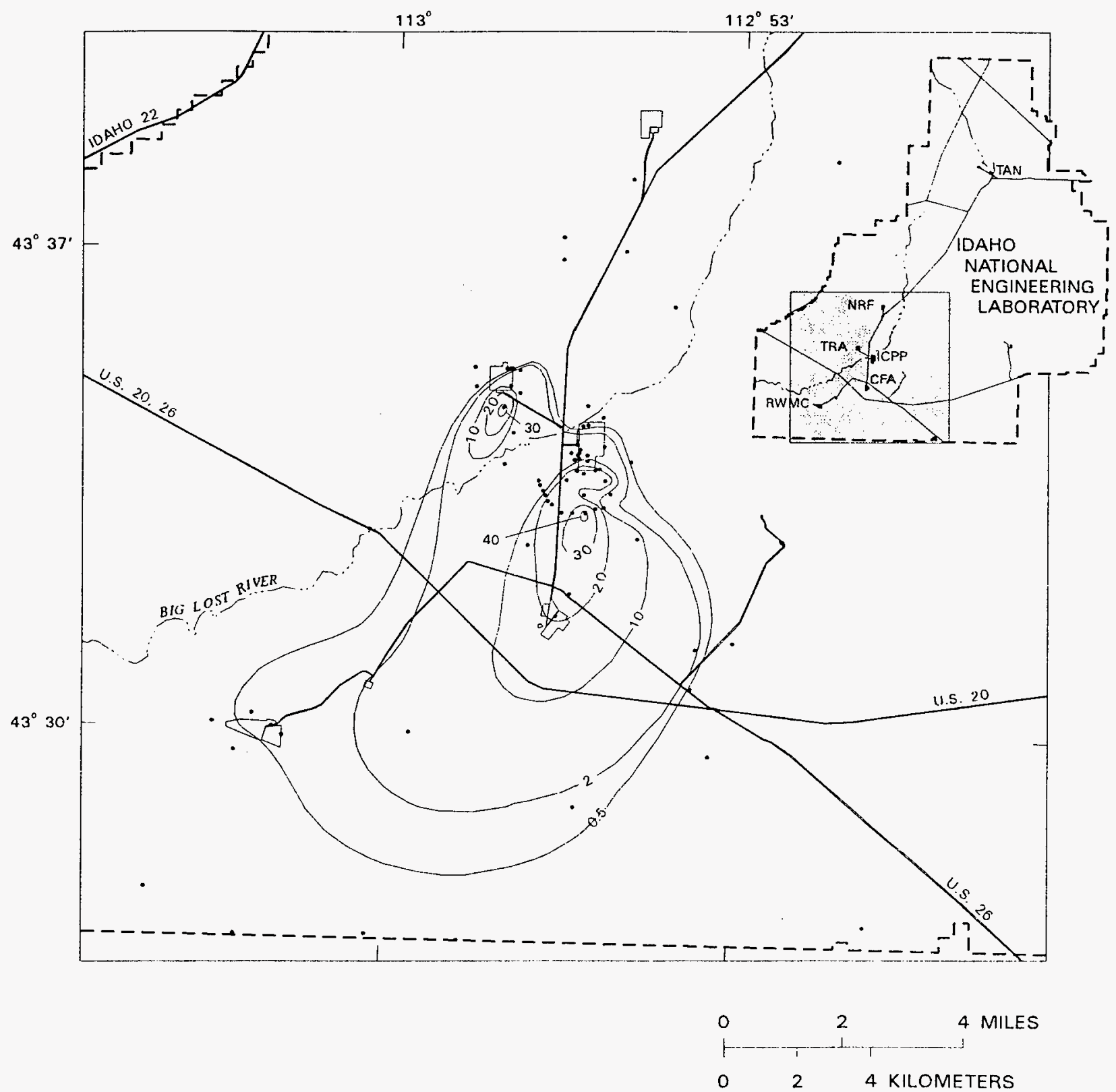

Figure 5.3 Distribution of tritium in the Snake River Plain Aquifer on the INEL, 1991 


\section{EXPLANATION}

- 40 - LINE OF EQUAL STRONTIUM-90 CONCENTRATION interval variable; concentration in picocuries per liter

WELL COMPLETED IN THE SNAKE RIVER PLAIN AQUIFER AND SAMPLED FOR STRONTIUM-9O

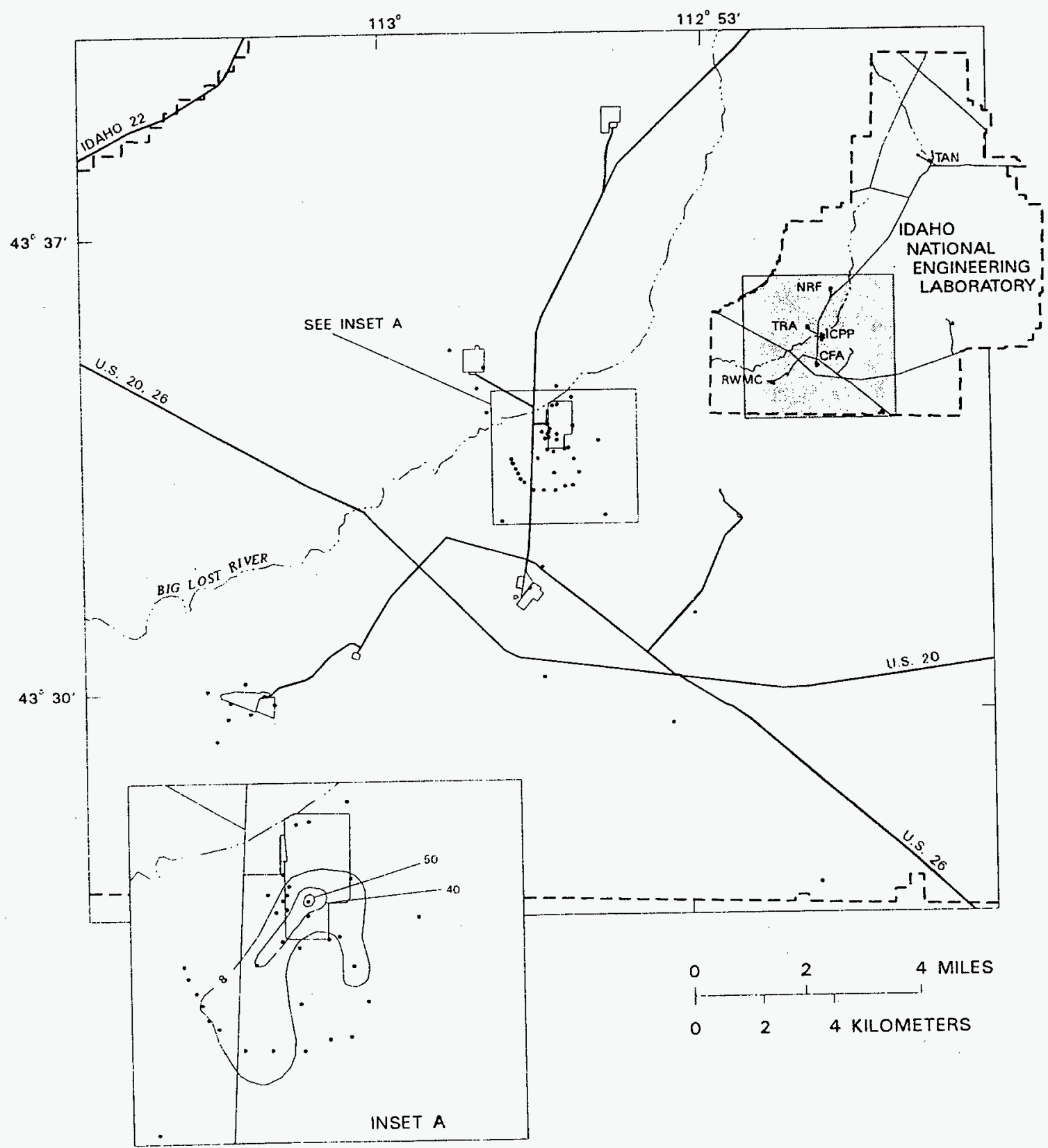

Figure 5.4 Distribution of ${ }^{90} \mathrm{Sr}$ in the Snake River Plain Aquifer on the INEL, 1991 


\section{Summary of USGS Special Studies}

\section{Study of the Snake River Plain Aquifer} South of the INEL. This document summarizes the results of some of the water samples taken in 1994 from the area hydrologically downgradient from the INEL, south to the Hagerman area ${ }^{a}$. This is part of a longterm study, begun in 1989 by the USGS in cooperation with the Idaho Department of Water Resources and the DOE, to determine any impacts on ground water south of the Site due to activities at the INEL. Water samples were collected from irrigation wells, domestic wells, two springs, a stock well, and an observation well. Samples were analyzed for selected radionuclides, stable isotopes of hydrogen, oxygen, carbon, sulfur, and nitrogen, inorganic constituents, and organic compounds. While many of the radionuclide and inorganic constituent concentrations exceeded the USGS reporting levels (results greater than the $3 \sigma$ uncertainty of the measurement), none exceeded the EPA's maximum contaminant levels for drinking water.

\section{Study of the Snake River Plain Aquifer at} the INEL. The USGS maintains a continuous monitoring network at the INEL to determine hydrologic trends and to delineate the movement of radiochemical and chemical wastes in the aquifer. This document presents an analysis of water level and water quality data collected from the Snake River Plain Aquifer during 1989-91 ${ }^{\mathrm{b}}$. Included are a number of

\footnotetext{
- R. C. Bartholomay, L. M. Williams, and L. J. Campbell, Radionuclides, Stable Isotopes, Inorganic Constituents, and Organic Compounds in Water from Selected Wells and Springs from the Southern Boundary of the Idaho National Engineering Laboratory to the Hagerman Area, Idaho, 1994; DOE/ID-22124; USCS Open-File Report 95-718; October 1995.

b R. C. Bartholomay, B. R. Orr, M. J. Liszewski, and R. G. Jensen, Hydrologic Conditions and Distribution of Selected Radiochemical and Chemical Constituents in Water, Snake River Plain Aquifer, Idaho National Engineering Laboratory, Idaho 1989 through 1991; DOE/ID-22123, August 1995.
}

maps showing ground-water flow direction, ground-water levels, and the distribution of contaminants (as of 1991). Figures 5.3 and 5.4 of this report come from the USGS document.

In general, concentrations of radionuclides decreased (e.g., $\left.{ }^{3} \mathrm{H}\right)$ or remained constant (e.g., ${ }^{90} \mathrm{Sr}$ ) during 1989-91. Concentrations of chemicals were variable during this same period. Lack of ground-water recharge from the Big Lost River, due to drought conditions, caused some of the chemical concentrations to increase slightly (e.g., sodium and chloride) or remain relatively constant (e.g., nitrate). During 1987-91, at least one of 19 purgeable organic compounds measured was detected in well water at the INEL. Plumes of 1,1,1trichloroethane have developed near the ICPP and RWMC as a result of previous waste disposal practices. The concentrations were well below the maximum contaminant level for drinking water.

Water Quality in the Vicinity of NRF. This report presents a compilation of water quality and quality assurance data for ground-water samples collected in the vicinity of the NRF during 1991-93'. This is part of a study, initiated in 1989 at the request of the DOE's Pittsburgh Naval Reactors Office, Idaho Branch Office, to provide water chemistry data to evaluate the impact of the NRF activities on the water quality of the Snake River Plain Aquifer.

Samples were collected from 14 wells (10 ground-water monitoring wells and four production wells) in and around the NRF area. The sampling, conducted in three phases, included a wide range of analyses of physical,

\footnotetext{
' B. J. Tucker, L. L. Knobel, and R. C. Bartholomay, Chemical Constituents in Water from Wells in the Vicinity of the Naval Reactors Facility; Idaho National Engineering Laboratory, Idaho, 1991-93; DOE/ID-22125; USGS Open-File Report 95-725; November 1995.
} 
chemical, and radiochemical parameters to characterize water chemistry.

\section{Stratigraphy of the Snake River Plain} Aquifer. Over the years, significant volumes of low-level radioactivity, chemical, and sanitary wastewater were discharged at TAN. Until 1972, waste was discharged into the Snake River Plain Aquifer through a 95-m (310-ft) deep disposal well. The impact has been seen in nearly all wells sampled at TAN for water quality.

In 1991, the USGS began a study of the stratigraphy of the unsaturated zone and uppermost part of the Snake River Plain Aquifer at $\mathrm{TAN}^{\mathrm{a}}$. Its purpose was to determine stratigraphic relations that may affect the migration of radioactive, chemical, and sanitary wastes from TAN to the Snake River Plain Aquifer. This document describes the stratigraphic framework of the unsaturated zone and uppermost part of the Snake River Plain Aquifer at TAN using geologic and geophysical data collected through March 1993.

Data collected for this and previous studies indicate numerous basalt flows and sedimentary interbeds in the subsurface at TAN. This report describes the stratigraphic relations between groups of related basalt flows and sedimentary interbeds in the unsaturated zone and uppermost part of the aquifer to a depth of $150 \mathrm{~m}(500 \mathrm{ft})$ below land surface. The complex stratigraphy around TAN contains features that could either increase or retard the rate of contaminant flow from TAN to the Snake River Plain Aquifer.

\footnotetext{
- S. R. Anderson and B. Bowers, Stratigraphy of the Unsaturated Zone and Uppermost Part of the Snake River Plain Aquifer at Test Area North, Idaho National Engineering Laboratory, Idaho; DOE/ID-22122, June 1995.
}

Basalt Core Samples. This report, prepared jointly by LITCO and USGS in cooperation with DOE, is part of a study to identify the chemistry of the Snake River Plain Aquifer host rock at the INEL to aid in the study of the hydrology and geochemistry of subsurface waste disposal ${ }^{b}$. Data are included from 84 selected basalt core samples for the 10 major rock-forming elements and their oxides, as well as 32 trace elements.

\section{Chemical Monitoring}

According to a recent USGS report on background concentrations of chemical constituents, operations at the INEL have affected local concentrations of several purgeable organic compounds including carbon tetrachloride, 1,1,1-trichloroethane, trichloroethylene, tetrachloroethylene, chloroform, and 1,1-dichloroethylene in the aquifer under the INEL $^{c}$. However, the INEL has apparently had no effect on the concentrations of other purgeable organic compounds, pesticides, or fluoride. In the trace elements group, operations have not affected concentrations of arsenic, barium, cadmium, mercury, or silver; but, they may have had a slight effect on the concentrations of dissolved chromium, lead, and selenium.

Sampling for purgeable organic compounds in ground water was conducted by the USGS at the INEL during 1995 . Water samples from three onsite production wells and 21 ground-water monitoring wells were collected by USGS personnel and submitted to

\footnotetext{
b L. L. Knobel, L. D. Cecil, and T. R. Wood, Chemical Composition of Selected Core Samples, Idaho National Engineering Laboratory, Idaho; DOE/ID-22126; USCS Open-File Report 95-748; November 1995.

c B. R. Orr, L. D. Cecil, L. L. Knobel, Background Concentrations of Selected Radionuclides, Organic Compounds, and Chemical Constituents in Groundwater in the Vicinity of the Idaho National Engineering Laboratory, U.S. Geological Survey, Water-Resources Investigations Report 91-4015, DOE/ID-22094, February 1991.
} 
the USGS National Water Quality Laboratory in Arvada, Colorado, for analysis of 61 purgeable organic compounds. A USGS report on the purgeable organic compounds sampling program describes the methods used to collect the water samples and ensure sampling and analytical quality ${ }^{\mathrm{a}}$. In the 1995 USGS set of samples from the INEL, five purgeable organic compounds were reported at concentrations above the laboratory reporting level of $0.2 \mu \mathrm{g} / \mathrm{L}$ : carbon tetrachloride, chloroform, 1,1,1-trichloroethane, trichloroethylene, and tetrachloroethylene (Table 5.1). The only production well sampled by the USGS in 1995 containing purgeable organic compounds was the RWMC production well. All detected concentrations were below the EPA maximum contaminant levels for each compound.

\subsection{INEL CONTRACTOR PROGRAM INFORMATION}

\section{Bacteriological Monitoring}

Potable water at the INEL was monitored for coliform bacteria monthly by contractor personnel and analyzed by the LITCO Environmental Hygiene Laboratory. Between 30 and 67 samples per month were collected from the active drinking water systems at INEL facilities. While "total coliform" bacteria may occasionally be detected in drinking water samples, concern arises only if Escherichia coli (E. coli) is present. Although most strains of $E$. coli are not dangerous and are normally found in human and animal intestines, the presence of this organism indicates possible contamination of the water

\footnotetext{
2 M. J. Liszewski and L. J. Mann, Purgeable Organic Compounds in Ground Water at the Idaho National Engineering Laboratory, Idaho-- 1990 and 1991, DOE/ID-22104, USCS Open-File Report 92-174, July 1992.
}

by fecal waste. If even one colony of $E$. coli is found in a sample by the laboratory, that particular drinking water system is cleaned, resampled, and tested again, until it is clear of bacteria. Corrective action to purify the water may vary somewhat from one facility to another.

While no samples from any of the INEL facilities during 1995 indicated the presence of $E$. coli, some samples showed positive results for coliform bacteria. ICPP showed positive results in February and November; TRA showed positive results in February and August; PBF showed positive results in July and August; TAN showed positive results for August; and CFA showed positive results for July, October, and December. Each system underwent corrective action to purify the potable water by chlorination, and then was retested to check the effectiveness of the purification process. The installation of a permanent chlorination system at TAN during 1995 effectively eliminated the persistent presence of coliform bacteria in the water.

NRF. Drinking water samples were collected monthly and analyzed for the presence of coliform bacteria. Frequency and sample locations met the requirements of applicable state and federal regulations. All sample results confirmed the absence of coliform bacteria in the NRF drinking water supply system.

\section{Radiological Monitoring}

All INEL contractors with liquid effluent streams containing radionuclides sample the waste streams and report the results of analyses on a monthly basis to the Radioactive Waste Management Information System operated by LITCO. A report is published annually showing the monthly radiological releases at all INEL facilities. 


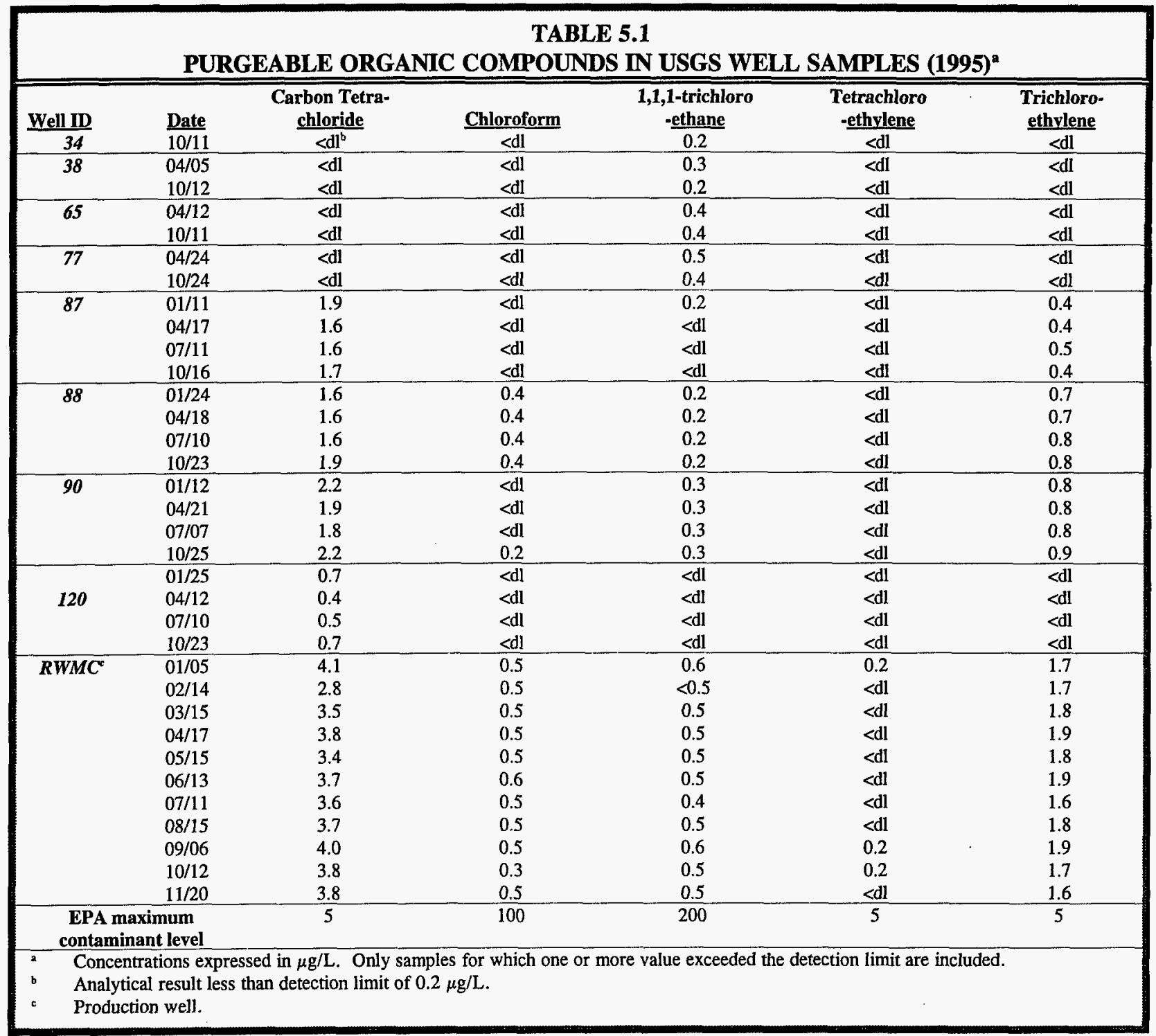

In the past, major contractors sampled drinking water wells at their facilities each quarter during one of every four years. These samples were then submitted for gross alpha, gross beta, and tritium analyses to an analytical laboratory that was either certified by the State of Idaho or certified by a state whose certification is accepted by the State of Idaho. In 1995, both RESL and Accu-Lab Research were certified by the State of Idaho for radiological analyses of drinking water, and the drinking water program fulfilled the compliance requirements for radiological monitoring at the INEL. Results of this program were discussed in Chapter 4 as part of the routine environmental surveillance program.

ANL-W. ANL-W sampled its Industrial Waste Pond and Primary Sanitary Lagoon monthly when these ponds were not frozen and analyzed the water for gross alpha, gross 
beta, tritium, and gamma-emitting radionuclides. No gross alpha, tritium, or gammaemitting radionuclides were detected in either pond. Gross beta activity was regularly detected in the Primary Sanitary Lagoon with values ranging from $2.9 \times 10^{-9}$ to $66 \times 10^{-9}$ $\mu \mathrm{Ci} / \mathrm{mL}$. No gross beta activity was detected in the Industrial Waste Pond.

\section{Chemical Monitoring}

ANL-W. The Safe Drinking Water Act implementing regulations required only monitoring for nitrites and nitrates in ANL-W production wells during 1995. Both parameters were well below applicable standards.

LITCO. The LITCO Environmental Monitoring Unit routinely samples drinking water from wells and distribution systems at facilities at the INEL for volatile organic compounds. At the Technical Service Facility (TSF) at TAN, the production wells and distribution systems are sampled more frequently since the discovery in 1987 that the trichloroethylene concentrations in samples collected at the wellhead exceeded the EPA maximum contaminant level. For TSF well $\# 1$, concentrations at the wellhead again exceeded the maximum contaminant level throughout 1995 (Table 5.2).

In 1988, an aerating device (sparger system) was installed at the point of entry to the distribution system to remove the volatile trichoroethylene from the drinking water in the system. Results from the routine monitoring program, which samples the water at the wellhead and in the distribution system, indicate the aeration system works well. Drinking water samples from the TSF distribution system have generally not exceeded the regulatory levels since installation of the sparger. During 1995, the TSF distribution system was in compliance. Drinking water is obtained only through the distribution systems, not from the wellheads. A plan for remedial action to address the localized contamination (near well \#1) in the aquifer was discussed in Chapter 3.

A sample taken from the wellhead at the RWMC production well was found to be above the EPA's maximum contaminant level for carbon tetrachloride during October. Water taken from the distribution system has remained below the maximum contaminant level, and followup samples from the wellhead collected in November and the first quarter of 1996 were also below the maximum contaminant level.

Chlorinated drinking water systems must also be monitored for total trihalomethanes (bromodichloromethane, bromoform, chloroform, and dibromochloromethane). The concentration of trihalomethanes in the Rifle Range production well remained well below the reporting level. The concentration in water from the CFA distribution system averaged about $2.5 \mu \mathrm{g} / \mathrm{L}$, or $2.5 \%$ of the EPA maximum contaminant level of $100 \mu \mathrm{g} / \mathrm{L}$.

During 1992, the INEL prime contractor initiated a semiannual monitoring program for lead and copper levels in drinking water in accordance with EPA regulations (40 CFR 141.80-141.91). Action levels are determined based on "90th percentile" values. An action level is exceeded if more than 10 percent of water samples collected during a six-month monitoring period exceed the regulatory values of $1.3 \mathrm{mg} / \mathrm{L}$ for copper and $0.015 \mathrm{mg} / \mathrm{L}$ for lead. In 1995, the 90th percentile value was not greater than the regulatory values for either contaminant. The year 1995 concluded three successive years of monitoring lead and copper levels in drinking water. Since regulatory values were not exceeded, and in accordance with regulations, this monitoring will be discontinued until 1998 . 


\begin{tabular}{|c|c|c|c|c|c|c|c|c|c|c|c|c|}
\hline \multirow[b]{2}{*}{ Well } & \multicolumn{10}{|c|}{$\begin{array}{c}\text { TABLE } 5.2 \\
\text { PURGEABLE ORGANIC COMPOUNDS }[\mu \mathrm{g} / \mathrm{L}] \mathrm{IN} \\
\text { INEL DRINKING WATER (1995) }\end{array}$} & \multirow[b]{2}{*}{ Nov } & \multirow[b]{2}{*}{$\underline{\text { Dec }}$} \\
\hline & \multicolumn{9}{|c|}{ Tetrachloroethylene (maximum contaminant level $=5 \mu \mathrm{g} / \mathrm{L}$ ) } & $\underline{\text { Oct }}$ & & \\
\hline TSF Dist. & 0.6 & $--^{a}$ & --- & --- & 0.5 & --- & --- & 1.0 & --- & 0.8 & 1.0 & 0.6 \\
\hline TSF \#1 & 2.8 & 2.0 & -- & 2.0 & -- & -- & --- & 2.8 & --- & --- & 2.9 & --- \\
\hline TSF \#2 & -- & 0.5 & --- & 0.6 & -- & --- & -- & 0.8 & --- & --- & 0.8 & -- \\
\hline \multicolumn{13}{|c|}{ Trichloroethylene (maximum contaminant level $=5 \mu \mathrm{g} / \mathrm{L}$ ) } \\
\hline CFA Dist. & -- & -- & $\overline{---}$ & -- & 1.3 & --- & $-\ldots$ & $-\cdots$ & --- & --- & -- & -- \\
\hline CFA \#1 & -- & --- & --- & -- & --- & --- & --- & --- & --- & --- & 1.4 & -- \\
\hline RWMC \#1 & -- & -- & -- & -- & 1.6 & -- & --- & -- & -- & 1.8 & 1.1 & -- \\
\hline RWMC Dist. & 0.9 & -- & --- & 1.2 & --- & --- & -- & 1.0 & --- & --- & 0.7 & -- \\
\hline TSF Dist. & 3.6 & 2.1 & 1.7 & 2.1 & 2.6 & 1.5 & 1.7 & 4.8 & -- & 3.2 & 4.3 & 2.8 \\
\hline TSF \#1 & 12.9 & 9.2 & --- & 7.8 & -- & --- & --- & 10.7 & --- & --- & 10.7 & -- \\
\hline TSF \#2 & -- & 2.0 & --- & 2.0 & -- & --- & -- & 2.9 & --- & --- & 2.3 & -- \\
\hline \multicolumn{13}{|c|}{ Ethylbenzene (maximum contaminant level $=700 \mu \mathrm{g} / \mathrm{L}$ ) } \\
\hline PBF Dist. & 5.9 & -- & --- & --- & --- & -- & --- & --- & --- & -- & -- & $\cdots$ \\
\hline \multicolumn{13}{|c|}{ Total Xylenes (maximum contaminant level $=10,000 \mu \mathrm{g} / \mathrm{L}$ ) } \\
\hline PBF Dist. & 17.0 & -- & --- & --- & $-\cdots$ & --- & -- & --- & --- & --- & $-\cdots$ & $\cdots$ \\
\hline \multicolumn{13}{|c|}{ p-Dichlorobenzene (maximum contaminant level $=75 \mu \mathrm{g} / \mathrm{L}$ ) } \\
\hline EBR-1 Dist. & -- & -- & --- & --- & --- & -- & --- & --- & --- & -- & 2.2 & $-\cdots$ \\
\hline \multicolumn{13}{|c|}{ Carbon Tetrachloride (maximum contaminant level $=5 \mu \mathrm{g} / \mathrm{L}$ ) } \\
\hline RWMC \#1 & --- & --- & --- & -- & 3.4 & -- & --- & -- & $-\cdots$ & 5.5 & 3.0 & $-\cdots$ \\
\hline RWMC Dist. & 1.7 & --- & --- & 2.0 & $-\cdots$ & --- & --- & 1.8 & --- & --- & 1.2 & --- \\
\hline \multicolumn{13}{|c|}{$1,1,1-$ Trichloroethane (maximum contaminant level $=5 \mu \mathrm{g} / \mathrm{L}$ ) } \\
\hline Main Gate Dist. & 1.0 & --- & --- & $-\ldots$ & -- & --- & --- & -- & --- & --- & --- & $-\ldots$ \\
\hline RWMC \#1 & -- & -- & --- & --- & --- & --- & $-\cdots$ & $-\cdots$ & -- & 0.6 & --- & -- \\
\hline
\end{tabular}

Additional sampling was conducted in 1995 for a variety of inorganic constituents, including metals, nitrates, dissolved solids. There were two isolated instances where the maximum contaminant levels were exceeded: on June 20 , the $\mathrm{pH}$ in the TRA distribution system was $8.8(\max \mathrm{pH}=8.5)$; on October 25 , the concentration of surfactants in the ICPP distribution system was $0.6 \mathrm{mg} / \mathrm{L}$ (maximum contaminant level $=0.5 \mathrm{mg} / \mathrm{L}$ ). More detailed information and data will be included in the Drinking Water Program 1995 Annual Report, INEL-96/0255(95), due to be published in August, 1996.

Water from the production and potable wells at the ICPP facility were analyzed monthly for a number of parameters (Table
5.3). None of these constituents were above the EPA maximum contaminant levels or State of Idaho drinking water limits in 1995.

NRF. Drinking water samples were collected from wellheads prior to entering the distribution system and monitored for volatile organic compounds, inorganic constituents, and water quality parameters. These samples were drawn from a sampling port immediately downstream from the NRF water softening treatment system. No volatile organic compounds were detected above the minimum detection levels established for the analyses of these compounds. Concentrations of inorganic analytes and water quality parameters were all below regulatory limits. 
Lead and copper monitoring of the NRF drinking water system continued in 1995 in accordance with applicable state and federal regulations. Results from all sample locations were below regulatory limits.

TABLE 5.3

INORGANIC CHEMICALS IN ICPP POTABLE AND PRODUCTION WELLS (1995) ${ }^{\mathrm{a}}$

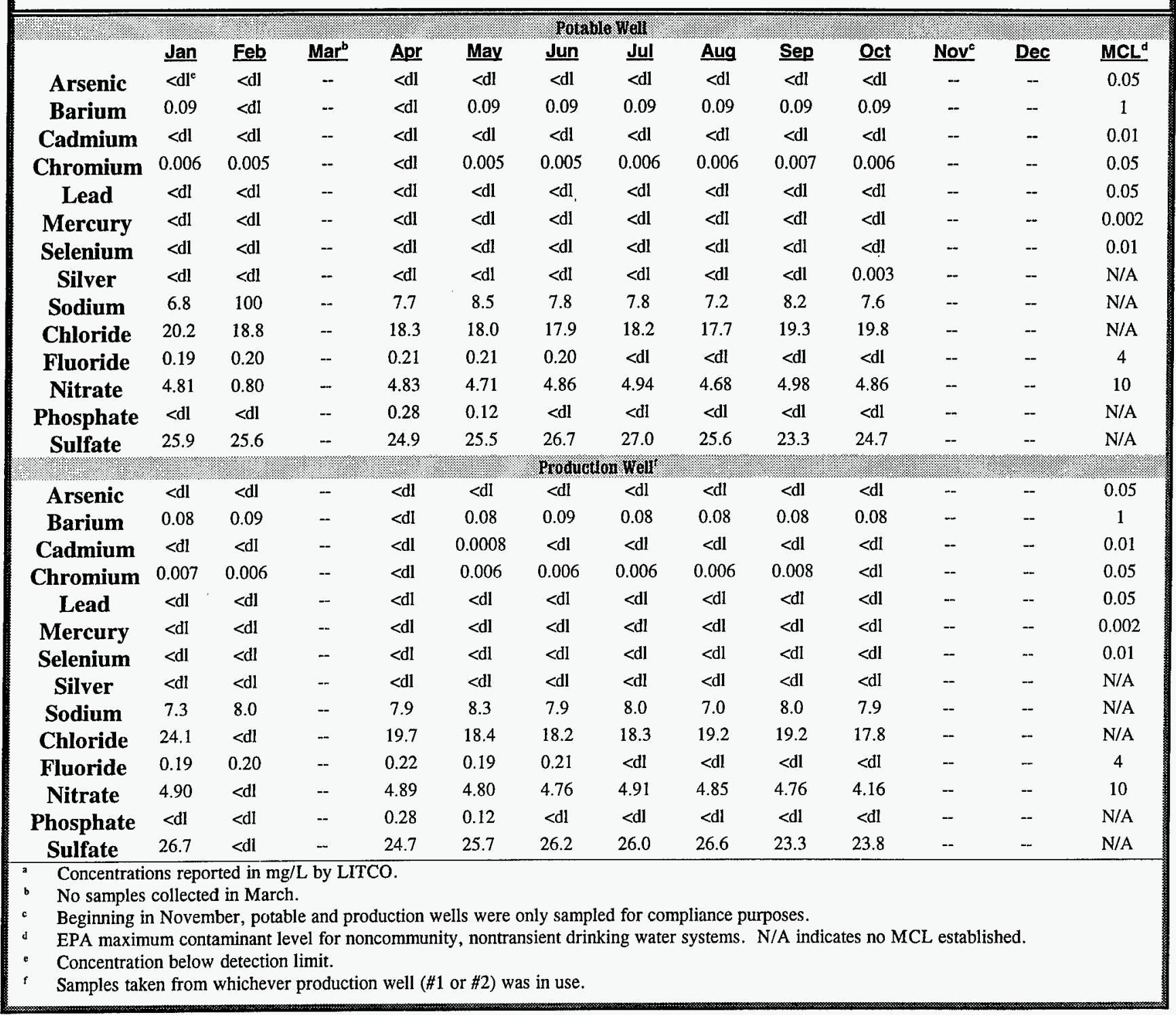




\title{
Chapter 6. ENVIRONMENTAL NONRADIOLOGICAL PROGRAM INFORMATION
}

\begin{abstract}
Chapter Summary
The environmental surveillance programs conducted by the Environmental Science and Research Foundation and Lockheed Idâho Technologies Company monitor a variety of nonradiological parameters at the Idẩo National Engineering Laboratory (INEL). This chapter describes the monitoring performed (Section 6.1), and the 1995 results for total suspended particulates, the Interagency Monitoring of Protected Visual Environments program, nitrogen dioxide and sulfür dioxide (Section 6.2).

Nonradioactive airborne effluents are released from INEL facilities through various production processes, the combustion of coal for steam generation, and the combustion of fuel of (section 63 ). Additional sources include motor vehicle exhausts and fugitive dusts from construction activities. This section provides a table of the releases of nitrogen dioxide and sulfur dioxide from NNEL facilities, and brief descriptions of the monitoring performed by facilities for these two parameters.
\end{abstract}

Nonradiological liquid effluents are disposed to ponds and sewage treatment facilities after discharges to the Snake River Plain Aquifer ceased in 1984 (Section 6.4). A summary of the monitoring performed at INEL facilities for these wastes is provided in this chapter. 
Chapter 6: Environmental Nonradiological Program Information

\section{ENVIRONMENTAL NONRADIOLOGICAL PROGRAM INFORMATION}

\subsection{ENVIRONMENTAL SURVEILLANCE PROGRAM DESCRIPTION}

\section{Total Suspended Particulates}

Measurements of total suspended particulates were performed on the particulate filters from the low-volume filters described in Chapter 4 by the Foundation. Clean filters were weighed at the beginning of each quarter and filter composites were weighed at the end of the quarter The concentration of total suspended particulates was calculated by dividing the amount of material collected on the filters by the total volume of air passing though the filters.

The EPA primary and secondary standard for particulate matter is $50 \mu \mathrm{g} / \mathrm{m}^{3}$, but it applies only to "particulates with an aerodynamic diameter less than or equal to a nominal 10 micrometers." Measurements of total suspended particulates overestimate particulate concentrations in the $10 \mu \mathrm{m}$ and below size range in comparison with the new standard. This is because the standard applies only to particles on the filter with diameters of $10 \mu \mathrm{m}$ or less, but many of the particles on the low-volume filters are actually larger than that size because there is no device on the samplers to screen out the larger particles. Particles larger than $10 \mu \mathrm{m}$ are not considered by the EPA to be respirable by humans because they do not usually enter the lungs with inhaled air. The larger particles usually fall out before they reach the nose, are trapped by nasal hairs, or are impacted on tissues of the nasopharynx and passed through the body via the digestive system.

\section{IMPROVE Samplers}

In May of 1992, one sampler was established at the CFA on the INEL and a second was located at Craters of the Moon National Monument as part of the National Park Service Interagency Monitoring of Protected Visual Environments (IMPROVE) aerosol network. This network has been in operation since March 1988 at national parks, monuments, and wilderness areas across the United States. Funding for the operation of the Craters of the Moon sampler is provided under a Memorandum of Understanding between the DOE and the National Park Service.

The two samplers, consisting only of Module A of the complete IMPROVE sampler (which may contain up to four modules), each collected two 24-hr samples weekly of fine particulates $(<2.5 \mu \mathrm{m}$ in diameter). Analyses for mass, optical absorption, hydrogen, carbon, nitrogen, and oxygen plus elements from sodium through lead on the periodic table were performed by Crocker Nuclear Laboratory at the University of California, Davis.

\section{Nitrogen Dioxide/Sulfur Dioxide Monitoring}

To fulfill one of the conditions specified in the Permit to Construct the Fuel Processing Restoration facility, two nitrogen oxide monitoring stations (which measure $\mathrm{NO}$ and $\mathrm{NO}_{2}$, collectively called $\mathrm{NO}_{\mathrm{x}}$ ) were operated by LITCO. These were located near the 
intersection of US Highway 20/26 and Van Buren Boulevard and at the Experimental Field Station (EFS). The analyzers used are designated as EPA equivalent methods.

One sulfur dioxide $\left(\mathrm{SO}_{2}\right)$ analyzer (also designated as an EPA equivalent method) was operated at the Van Buren location in addition to the nitrogen dioxide analyzer.

\subsection{ENVIRONMENTAL SURVEILLANCE PROGRAM RESULTS}

\section{Total Suspended Particulates}

Results for 1995 indicated the annual mean of quarterly total suspended particulate concentrations, as measured by the Foundation, ranged from $13 \mu \mathrm{g} / \mathrm{m}^{3}$ at the EFS onsite location to $60 \mu \mathrm{g} / \mathrm{m}^{3}$ at the offsite locations of Idaho Falls and Arco (Table 6.1). Higher particulate concentrations were found at distant and boundary locations than on the INEL. The largest source of airborne particulates in the vicinity of the INEL is considered to be resuspended dust from high winds and agricultural operations. Total suspended particulate concentrations for 1986-1995 are provided in Table 6.2 .

\section{IMPROVE Samplers}

The latest data available for this report was for the period September 1994 through August 1995. A summary of results obtained during this time period is shown in Table 6.3.

\section{Nitrogen Dioxide}

The New Waste Calcining Facility (NWCF) at ICPP, the largest single source of $\mathrm{NO}_{2}$ on the INEL, did not operate during 1995. Mean nitrogen dioxide concentrations for 1995 were $4.0 \mu \mathrm{g} / \mathrm{m}^{3}$ (2.1 parts per billion) at EFS and $3.8 \mu \mathrm{g} / \mathrm{m}^{3}$ (2.0 parts per billion) at Van Buren, lower than the EPA national primary ambient air quality standard of $100 \mu \mathrm{g} / \mathrm{m}^{3}$. Data recovery for the year was about $90 \%$ at Van Buren and $96 \%$ at EFS.

\section{Sulfur Dioxide}

The mean $\mathrm{SO}_{2}$ concentration for 1995 was $2.1 \mu \mathrm{g} / \mathrm{m}^{3}$ ( 0.8 parts per billion), or $2.6 \%$ of the annual primary air quality standard. The maximum daily concentration of $10 \mu \mathrm{g} / \mathrm{m}^{3}(3.9$ parts per billion) was $2.8 \%$ of the primary standard for a 24-hour period. The maximum recorded three-hour average of $15 \mu \mathrm{g} / \mathrm{m}^{3}(5.5$ parts per billion) was $1.1 \%$ of the EPA secondary standard. The analyzer operated satisfactorily for $94 \%$ of the year.

\subsection{NONRADIOLOGICAL AIRBORNE EFFLUENTS}

\section{Summary}

Nonradioactive airborne effluents originate from five primary sources at the INEL: calcination of high-level radioactive liquid waste at the NWCF, combustion of coal for steam generation at the CFSGF, combustion of fuel oil for heating at all INEL facilities, motor 
Chapter 6: Environmental Nonradiological Program Information

\begin{tabular}{|c|c|c|c|}
\hline & ATE MATTER & RATIONS I & (1995) \\
\hline & & Concentra & $\left.\mu \mathrm{g} / \mathrm{m}^{3}\right)$ \\
\hline Group & Location & Range & Mean $^{a}$ \\
\hline $\overrightarrow{\text { Distant }}$ & Blackfoot & $0-35$ & $20 \pm 30$ \\
\hline & Craters of the Moon & $0-70$ & $20 \pm 60$ \\
\hline & Idaho Falls : & $10-130$ & $60 \pm 80$ \\
\hline & Rexburg & $10-70$ & $\underline{30 \pm 40}$ \\
\hline & & Grand Mean ${ }^{a}$ & $32 \pm 30$ \\
\hline Boundary & Arco & $10-90$ & $60 \pm 50$ \\
\hline & Atomic City & $0-70$ & $20 \pm 50$ \\
\hline & FAA Tower & $0-100$ & $29 \pm 90$ \\
\hline & Howe & $10-60$ & $30 \pm 40$ \\
\hline & Monteview & $10-70$ & $30 \pm 50$ \\
\hline & Mud Lake & $10-60$ & $30 \pm 30$ \\
\hline & Reno Ranch & $0-70$ & $20 \pm 60$ \\
\hline & & Grand Mean ${ }^{a}$ & $28 \pm 13$ \\
\hline INEL & EFS & $0-70$ & $13 \pm 60$ \\
\hline & Main Gate & $0-60$ & $15 \pm 60$ \\
\hline & Van Buren & $10-60$ & $\underline{30+40}$ \\
\hline & & Grand Mean ${ }^{a}$ & $20 \pm 67$ \\
\hline
\end{tabular}

vehicle exhausts, and fugitive dusts from waste burial and construction activities.

Nitrogen oxide emissions are routinely monitored by LITCO at the NWCF, and sulfur dioxide, nitrogen oxides, and carbon oxides are monitored at the CFSGF. Both facilities are located at the ICPP. These monitoring data are published in the INEL Nonradiological Waste Management Information System (INWMIS) quarterly reports.

The Foundation calculated the maximum sulfur dioxide and nitrogen dioxide concentrations at the INEL boundary using the total annual discharges as reported by the INWMIS and the MESODIF air dispersion model. The calculational method is essentially the same as described in chapter 4 in the section "Evaluation of Potential Radiation Dose to the
Public," using mass units for releases instead of radioactivity units.

Emissions of sulfur dioxide from heating oils are calculated from sulfur content and the amount of fuel used at all INEL facilities and are reported to the INWMIS. Emissions of nitrogen oxides from fuel were calculated using emission factors developed by the EPA ${ }^{\mathrm{a}}$ and the amount and type of fuel burned at each facility as reported by the INWMIS. Motor vehicle exhausts and fugitive dusts are not monitored at their sources.

Total sulfur dioxide released in 1995 was about 110 megagrams (Mg) (Table 6.4). A Mg is sometimes referred to as a metric ton and is

- U.S. Environmental Protection Agency, Compilation of Air Pollutant Emission Factors, AP-42, Part A, August 1982, pp. 1.3-2. 


\begin{tabular}{|c|c|c|c|}
\hline \multicolumn{4}{|c|}{$\begin{array}{c}\text { TABLE } 6.2 \\
\text { TEN-YEAR SUMMARY OF PARTICULATE MATTER } \\
\text { CONCENTRATIONS (1986-1995) }\end{array}$} \\
\hline & \multicolumn{3}{|c|}{ Group Mean Concentration $\left(\mu \mathrm{g} / \mathrm{m}^{3}\right)^{\mathbf{a}}$} \\
\hline & Distant Group & Boundary Group & INEL Group \\
\hline 1986 & $39 \pm 17$ & $31 \pm 9$ & $23 \pm 6$ \\
\hline 1987 & $45 \pm 16$ & $34 \pm 8$ & $28 \pm 8$ \\
\hline 1988 & $50 \pm 20$ & $35 \pm 9$ & $32 \pm 13$ \\
\hline 1989 & $40 \pm 14$ & $30 \pm 7$ & $17 \pm 2$ \\
\hline 1990 & $36 \pm 12$ & $32 \pm 8$ & $20 \pm 9$ \\
\hline 1991 & $30 \pm 20$ & $28 \pm 12$ & $18 \pm 3$ \\
\hline 1992 & $26 \pm 19$ & $23 \pm 10$ & $13 \pm 2$ \\
\hline 1993 & $21 \pm 21$ & $18 \pm 8$ & $13 \pm 3$ \\
\hline 1994 & $28 \pm 28$ & $23 \pm 7$ & $25 \pm 4$ \\
\hline 1995 & $32 \pm 30$ & $28 \pm 13$ & $20 \pm 67$ \\
\hline
\end{tabular}

equivalent to $2200 \mathrm{lb}$. The maximum concentration of sulfur dioxide at the southern INEL boundary, where the MESODIF model predicted the highest concentration, was 0.13 $\mu \mathrm{g} / \mathrm{m}^{3}$, which is $0.16 \%$ of the national primary ambient air quality standard of $80 \mu \mathrm{g} / \mathrm{m}^{3}$.

The releases of nitrogen oxides during 1995 are also shown in Table 6.4. When the nitrogen oxide was converted to nitrogen dioxide (the parameter for which standards are written), the total released equaled about $120 \mathrm{Mg}$. The calculated maximum INEL boundary concentration of nitrogen dioxide was $0.14 \mu \mathrm{g} / \mathrm{m}^{3}$ from all INEL sources. This concentration is $0.14 \%$ of the national primary ambient air quality standard of $100 \mu \mathrm{g} / \mathrm{m}^{3}$.

\section{ANL-W}

At ANL-W, the Experimental Breeder Reactor II Auxiliary Boilers do not require continuous monitoring because they are below the State of Idaho's 250 million BTU/hr monitoring limit. The boiler emissions are monitored monthly as an efficiency check and to ensure that $\mathrm{NO}_{\mathrm{x}}$ and $\mathrm{SO}_{2}$ levels are below State-imposed emission limits. Personnel use a portable stack emission monitor that gives a direct printout of ambient and stack temperature, carbon monoxide, carbon dioxide, sulfur dioxide, nitrogen oxides, and oxygen. If any parameter is outside prescribed limits, the boiler is checked for improper operation and corrective action is initiated. In 1995 , the $\mathrm{NO}_{\mathrm{x}}$ analyses ranged from 19 to $230 \mathrm{mg} / \mathrm{m}^{3}$ (10 to 122 parts per million) and $\mathrm{SO}_{2}$ ranged between 13 and $98 \mathrm{mg} / \mathrm{m}^{3}$ ( 5 and 37 parts per million).

\section{SMC}

Nonradiological airborne effluents from SMC include particulate matter, nitrogen 
Chapter 6: Environmental Nonradiological Program Information

\begin{tabular}{|c|c|c|c|c|c|c|}
\hline \multirow[b]{3}{*}{ Constituent } & \multicolumn{5}{|c|}{$\begin{array}{l}\text { TABLE } 6.3 \\
\text { ROVE SAMPLERS AT CFA AND } \\
\text { E MOON NATIONAL MONUMENT } \\
\text { BER } 1994 \text { - AUGUST 1995) }\end{array}$} & \\
\hline & \multicolumn{2}{|c|}{$\%$ Detected $^{\mathrm{b}}$} & \multicolumn{2}{|c|}{ Range } & \multicolumn{2}{|c|}{ Mean $^{c}$} \\
\hline & CFA & Craters & CFA & Craters & CFA & Craters \\
\hline Hydrogen & 100 & 100 & $26-693$ & $19-721$ & $148 \pm 20$ & $122 \pm 20$ \\
\hline Sodium & 38 & 56 & $<\mathrm{dl}^{\mathrm{d}}-92$ & $<\mathrm{dl}-257$ & $19 \pm 3$ & $24 \pm 6$ \\
\hline Magnesium & 38 & 31 & $<\mathrm{dl}-294$ & $<\mathrm{dl}-100$ & $19 \pm 7$ & $11 \pm 3$ \\
\hline Aluminum & 86 & 91 & $<\mathrm{dl}-1095$ & $<\mathrm{dl}-785$ & $65 \pm 24$ & $50 \pm 17$ \\
\hline Silicon & 99 & 100 & $<\mathrm{dl}-2869$ & : $10-582$ & $170 \pm 64$ & $102 \pm 22$ \\
\hline Phosphorus & 23 & 8 & $<\mathrm{dl}-57$ & $<\mathrm{dl}-36$ & $6.0 \pm 2.0$ & $5.0 \pm 1.4$ \\
\hline Sulfur & 100 & 23 & $37-502$ & $16-548$ & $171 \pm 19$ & $144 \pm 19$ \\
\hline Chlorine & 6 & 10 & $<\mathrm{dl}-11$ & $<\mathrm{dl}-15$ & $2.6 \pm 0.3$ & $2.4 \pm 0.3$ \\
\hline Potassium & 97 & 99 & $<\mathrm{dl}-319$ & $<\mathrm{dl}-289$ & $37 \pm 10$ & $28 \pm 7$ \\
\hline Calcium & 99 & 99 & $<\mathrm{dl}-262$ & $<\mathrm{dl}-156$ & $44 \pm 10$ & $29 \pm 6$ \\
\hline Titanium & 69 & 77 & $<\mathrm{dl}-75$ & $<\mathrm{dl}-16$ & $5.4 \pm 1.7$ & $3.9 \pm 0.7$ \\
\hline Vanadium & 40 & 41 & $<\mathrm{dl}-5.3$ & $<\mathrm{dl}-4.9$ & $1.3 \pm 0.2$ & $1.3 \pm 0.2$ \\
\hline Chromium & 23 & 25 & $<\mathrm{dl}-2.8$ & $<\mathrm{dl}-2.7$ & $0.8 \pm 0.1$ & $0.8 \pm 0.1$ \\
\hline Manganese & 37 & 40 & $<\mathrm{dl}-15$ & $<\mathrm{dl}-8.9$ & $1.4 \pm 0.4$ & $1.2 \pm 0.2$ \\
\hline Iron & 100 & 100 & $1-706$ & $1-148$ & $39 \pm 16$ & $25 \pm 6$ \\
\hline Nickel & 12 & 14 & $<\mathrm{dl}-0.14$ & $<\mathrm{dl}-0.4$ & $0.06 \pm 0.04$ & $0.06 \pm 0.01$ \\
\hline Copper & 93 & 78 & $<\mathrm{dl}-4.2$ & $<\mathrm{dl}-2.3$ & $0.5 \pm 0.1$ & $0.4 \pm 0.1$ \\
\hline Zinc & 100 & 100 & $0.2-5.0$ & $0.3-8.9$ & $1.6 \pm 0.2$ & $1.7 \pm 0.3$ \\
\hline Arsenic & 30 & 37 & $<\mathrm{dl}-1.0$ & $<\mathrm{dl}-1.9$ & $0.16 \pm 0.03$ & $0.18 \pm 0.04$ \\
\hline Lead & 95 & 93 & $<\mathrm{dI}-3.0$ & $<\mathrm{dl}-2.5$ & $0.7 \pm 0.1$ & $0.6 \pm 0.1$ \\
\hline Selenium & 81 & 77 & $<\mathrm{dl}-0.8$ & $<\mathrm{dl}-1.3$ & $0.23 \pm 0.04$ & $0.17 \pm 0.03$ \\
\hline Bromine & 100 & 100 & $0.2-5.7$ & $0.2-4.1$ & $1.3 \pm 0.2$ & $1.3 \pm 0.2$ \\
\hline Rubidium & 70 & 55 & $<\mathrm{dl}-1.4$ & $<\mathrm{dl}-0.4$ & $0.15 \pm 0.03$ & $0.10 \pm 0.01$ \\
\hline Strontium & 77 & 71 & $<\mathrm{dl}-1.5$ & $<\mathrm{dl}-0.7$ & $0.25 \pm 0.05$ & $0.20 \pm 0.03$ \\
\hline Zirconium & 20 & 5 & $<\mathrm{dl}-2.0$ & $<\mathrm{dl}-1.7$ & $0.16 \pm 0.04$ & $0.15 \pm 0.03$ \\
\hline Molybdenum & 7 & $\therefore 5$ & $<\mathrm{dl}-2.8$ & $<\mathrm{dl}-3.7$ & $1.4 \pm 0.2$ & $1.4 \pm 0.2$ \\
\hline \multicolumn{7}{|c|}{$\begin{array}{l}\text { Units expressed in nanograms } / \mathrm{m}^{3} \text {. } \\
\text { Percentage of samples analyzed that were greater than the detection limit for that parameter. } \\
\text { Arithmetic mean with the } 95 \% \text { confidence interval for the mean. } \\
\text { At least one value was below the detection limit for that parameter. }\end{array}$} \\
\hline
\end{tabular}

oxides, sulfur dioxide, carbon monoxide, volatile organic compounds and toxic air pollutants. Personnel at the facility have determined that particulate matter originates from combustion sources, manufacturing processes, emergency generators, welding sources, an incinerator and a carpenter shop. Emissions of $\mathrm{NO}_{\mathrm{x}}, \mathrm{SO}_{2}$ and carbon monoxide, are generated primarily from boiler and generator operations. During 1995, the acid-etching system, which released nitrogen dioxide in the process of cleaning depleted uranium plates, was not used. Under DOE-ID's pollution prevention program, it was replaced with a high-pressure water-jet system.

\subsection{NONRADIOLOGICAL LIQUID EFFLUENTS}

\section{Summary}

Nonradioactive liquid effluents are disposed primarily to the following areas: an industrial waste ditch and evaporative sewage lagoon at the Naval Reactors Facility; seepage ponds at the Contained Test Facility, Technical Services Facility, Test Reactor Area, Idaho Chemical Processing Plant, and Water Reactor Research Test Facility; an industrial waste pond at 


\begin{tabular}{|c|c|c|c|c|c|c|c|c|c|c|}
\hline \multirow[b]{3}{*}{ Facility } & \multicolumn{10}{|c|}{$\begin{array}{l}\text { OF } \mathrm{NO}_{2} \text { AND } \mathrm{SO}_{2} \text { EMISSIONS AND AMBIENT } \\
\text { MONITORING RESULTS (1991-1995) }\end{array}$} \\
\hline & \multicolumn{5}{|c|}{$\mathrm{Mg} \mathrm{NO}_{2}{ }^{\mathrm{a}}$} & \multicolumn{5}{|c|}{$\mathrm{Mg} \mathrm{SO}_{2}{ }^{\mathrm{a}}$} \\
\hline & $\underline{1991}$ & $\underline{1992}$ & 1993 & 1994 & $\underline{1995}$ & $\underline{1991}$ & 1992 & 1993 & 1994 & 1995 \\
\hline ANL-W & 3 & 5 & 6 & 5 & 6 & 8 & 10 & 13 & 15 & $\overline{17}$ \\
\hline CFA & 1 & 1 & 2 & 1 & 1 & 3 & 3 & 5 & 3 & 2 \\
\hline ICPP (CFSGF) & 22 & 107 & 87 & 57 & 91 & 5 & 17 & 9 & 4 & 9 \\
\hline ICPP (oil) & 13 & 2 & 6 & 10 & 2 & 86 & 14 & 44 & 71 & 18 \\
\hline ICPP (main stack) & 501 & 5 & 467 & --- & -- & -- & $\cdots$ & --- & --. & $-\cdots$ \\
\hline NRF & 17 & 17 & 18 & 13 & 10 & 10 & 45 & 40 & 60 & 39 \\
\hline PBF & --- & - & --- & --- & 0.3 & 1 & 1 & -- & --- & 1 \\
\hline SMC & --- & 3 & 5 & 4 & 3 & --- & 8 & 11 & 9 & 7 \\
\hline TRA & 3 & 3 & 3 & 2 & 3 & 10 & 10 & 7 & 7 & 9 \\
\hline TSF & 4 & 3 & 4 & 9 & 5 & 11 & 8 & 9 & 17 & 7 \\
\hline WRRTF & 1 & 1 & --- & 1 & 0.3 & 1 & 1 & 1 & 2 & 1 \\
\hline Totals & 566 & 147 & 598 & 102 & 122 & 135 & 117 & 139 & 188 & 110 \\
\hline \multicolumn{11}{|c|}{ Ambient Monitoring $\left(\mu \mathrm{g} / \mathrm{m}^{3}\right)$} \\
\hline EFS & 7.2 & 12.5 & 36 & 15.4 & 4.0 & --- & -- & -- & -- & --- \\
\hline VANB & 5.2 & 4.9 & 9.4 & 4.9 & 3.8 & 0.0 & 0.8 & 1.8 & 2.7 & 2.1 \\
\hline
\end{tabular}

Argonne National Laboratory-West; and sewage treatment facilities at various locations.

Routine direct disposal of wastes to the Snake River Plain Aquifer ceased in 1984. The only other injection wells on the INEL are used for storm water runoff. No waste streams, other than storm water runoff, are discharged directly to the Big Lost River, the only surface stream on the INEL that might conceivably accept wastewater. As described in Chapter 2, the INEL has initiated a storm-water monitoring program.

Other waste effluents are calculated from the amounts of chemicals used for water treatment, corrosion control, demineralization, cleansers, algicides, and occasionally from waste acids. Sewage processed by treatment facilities is monitored for biochemical oxygen demand, dissolved oxygen, settleable solids, and $\mathrm{pH}$. Results of monitoring sanitary waste streams for these parameters at all INEL facilities are reported quarterly by the INWMIS.

\section{ANL-W}

During 1995, personnel at ANL-W monitored the Industrial Waste Pond at their facility for $\mathrm{pH}$, temperature, conductivity, dissolved oxygen, turbidity, iron, sodium, mercury, chloride, fluoride, sulfate, and phosphate. The Primary Sanitary Lagoon was monitored for $\mathrm{pH}$, temperature, conductivity, dissolved oxygen, biological oxygen demand, total suspended 
Chapter 6: Environmental Nonradiological Program Information

solids, iron, sodium, chloride, sulfate, and fluoride.

\section{LITCO}

In fiscal year 1986, EG\&G Idaho, the prime INEL contractor at that time, instituted a Nonradiological Liquid Effluent Monitoring Program to provide environmental monitoring for nonradioactive parameters and pollutants in liquid waste effluents generated within its facilities at the INEL. The program involves sampling, analysis, and data interpretation carried out under a rigorous quality assurance program. A more complete description of the program-effluent stream descriptions, sampling regimes, analytical methods, and presentation and interpretation of the data-were published annually by EG\&G Idaho through 1993 and are now produced by LITCO.

Inorganic monitoring data from one of the more significant of these waste streams, the liquid effluent to the TRA Cold Waste Pond, are presented in Table 6.5. According to LITCO monitoring data, metal concentrations were below the applicable regulatory limits for liquid effluent streams at all facilities operated by the contractor in 1995 .

SMC. Most radioactive and hazardous liquid wastes at SMC are recycled or processed through a drum evaporator with the final residue disposed as solid waste. Other hazardous, mixed hazardous, and radioactive wastes are containerized at Satellite Accumulation Areas within the facility, characterized, and transported to appropriate INEL storage facilities for final preparation and disposal to an offsite facility.

Boiler effluent and sanitary wastewater were released to the TAN 750 evaporation pond. A sampling program was established at SMC to collect baseline data for liquid effluent releases beginning in September 1992. As a result of analyses, the facility determined that, beginning in 1994, the number of analytes measured each month could be reduced without risk to the environment. A complete set of analyses would be performed twice per year.

ICPP. The extent of effluent monitoring for liquid waste streams varies depending on the nature of the effluents. The service waste at the ICPP, is monitored by monthly composite samples analyzed for the analytes of interest shown in Table 6.6. All parameters were below the concentrations defined as hazardous waste in 40CFR 261.24.

\section{NRF}

At NRF, nonradiological liquid effluents are disposed to an industrial waste ditch and evaporative sewage lagoon. Liquid effluent monitoring at NRF confirmed no hazardous wastes were discharged from the NRF site in 1995, and that all liquid effluents were controlled in accordance with applicable federal and state laws. Specifics regarding this monitoring are published annually in a separate report prepared and issued by NRF as prefaced in this report. 
TABLE 6.5

TRA LIQUID EFFLUENT INORGANIC MONITORING DATA (1995)

\begin{tabular}{|c|c|c|c|c|c|}
\hline \multirow[b]{2}{*}{ Parameter } & \multicolumn{4}{|c|}{ Concentration $^{\mathrm{a}}$} & \multirow[b]{2}{*}{ Toxicity Limit $^{\mathrm{h}}$} \\
\hline & February & $\underline{\text { May }}$ & August & November & \\
\hline Conductivity & 990 & 863 & 1108 & 13.0 & --- \\
\hline pH & 7.5 & 7.8 & 7.5 & 7.5 & 2 to 12.5 \\
\hline Chemical Oxygen Demand & 11.6 & 12.8 & $<\mathrm{dl}^{\mathrm{c}}$ & $<\mathrm{dl}$ & -- \\
\hline Biochemical Oxygen Demand & 4.0 & 2.0 & 9.0 & 4.0 & -- \\
\hline Total Organic Carbon & 3.8 & 4.4 & $<\mathrm{dl}$ & 0.68 & --- \\
\hline Total Dissolved Solids & 889 & 250 & 270 & 710 & --- \\
\hline Total Suspended Solids & $<\mathrm{dl}$ & $<\mathrm{dl}$ & 6.6 & $<\mathrm{dl}$ & --- \\
\hline Chloride Ion & 28.9 & 27.1 & 32.3 & 11.1 & --- \\
\hline Fluoride Ion & 0.37 & 0.34 & 0.38 & 0.11 & --- \\
\hline Nitrate as Nitrogen & 2.9 & 2.2 & 2.9 & 1.1 & -- \\
\hline Total Nitrogen & 0.25 & 4.2 & $<\mathrm{dl}$ & $<\mathrm{dl}$ & --- \\
\hline Total Phosphorus & 1.9 & 1.4 & 1.7 & $<\mathrm{dl}$ & --- \\
\hline MBAS $^{\mathrm{d}}$ & $<\mathrm{dl}$ & $<\mathrm{dl}$ & $<\mathrm{dl}$ & $<\mathrm{dl}$ & --- \\
\hline Silver & $<\mathrm{dl}$ & $<\mathrm{dl}$ & $<\mathrm{dl}$ & $<\mathrm{dl}$ & 5 \\
\hline Arsenic & 0.014 & 0.013 & 0.012 & $<\mathrm{dl}$ & 5 \\
\hline Barium & $<\mathrm{dl}$ & $<\mathrm{dl}$ & $<\mathrm{dI}$ & $<\mathrm{dl}$ & 100 \\
\hline Beryllium & $<\mathrm{dl}$ & $<\mathrm{dl}$ & $<\mathrm{dl}$ & $<\mathrm{dl}$ & --- \\
\hline Calcium & 124 & 101 & 122 & 439 & --- \\
\hline Cadmium & $<\mathrm{dl}$ & $<\mathrm{dl}$ & $<\mathrm{dl}$ & $<\mathrm{dl}$ & 1 \\
\hline Cobalt & $<\mathrm{dl}$ & $<\mathrm{dl}$ & $<\mathrm{dl}$ & $<\mathrm{dl}$ & --- \\
\hline Chromium & $<\mathrm{dl}$ & $<\mathrm{dl}$ & $<\mathrm{dl}$ & $<\mathrm{dl}$ & 5 \\
\hline Copper & $<\mathrm{dl}$ & $<\mathrm{dl}$ & $<\mathrm{dl}$ & $<\mathrm{dl}$ & -- \\
\hline Iron & 0.20 & 0.15 & 0.13 & $<\mathrm{dl}$ & -- \\
\hline Mercury & $<\mathrm{dl}$ & $<\mathrm{dl}$ & $<\mathrm{dl}$ & $<\mathrm{dl}$ & 0.2 \\
\hline Potassium & 9.8 & 8.1 & 11.1 & $<\mathrm{dl}$ & -- \\
\hline Magnesium & 43.7 & 38.0 & 46.2 & 16.5 & $\ldots$ \\
\hline Manganese & $<\mathrm{dl}$ & $<\mathrm{dl}$ & $<\mathrm{dl}$ & $<\mathrm{dl}$ & $\cdots$ \\
\hline Sodium & 22.3 & 17.2 & 22.8 & 7.5 & --- \\
\hline Nickel & $<\mathrm{dl}$ & $<\mathrm{dl}$ & $<\mathrm{dl}$ & $<\mathrm{dl}$ & --- \\
\hline Lead & $<\mathrm{dl}$ & $<\mathrm{dl}$ & $<\mathrm{dl}$ & $<\mathrm{dl}$ & 5 \\
\hline Antimony & $<\mathrm{dl}$ & $<\mathrm{dl}$ & $<\mathrm{dl}$ & $<\mathrm{dl}$ & --- \\
\hline Selenium & $<\mathrm{dl}$ & $<\mathrm{dl}$ & $<\mathrm{dl}$ & $<\mathrm{dl}$ & 1 \\
\hline Thallium & $<\mathrm{dl}$ & $<\mathrm{dl}$ & $<\mathrm{dl}$ & $<\mathrm{dl}$ & $\ldots$ \\
\hline Zinc & $<\mathrm{dl}$ & $<\mathrm{dl}$ & $<\mathrm{dl}$ & 0.03 & $\ldots$ \\
\hline
\end{tabular}


TABLE 6.6

ICPP SERVICE WASTE INORGANIC MONITORING DATA (1995) ${ }^{\mathrm{a}}$

\begin{tabular}{|c|c|c|c|c|c|c|c|c|c|c|c|c|c|}
\hline & $\underline{\mathrm{Jan}}$ & $\underline{\text { Feb }}$ & Mar & Apr & May & $\underline{\text { Jun }}$ & $\underline{\mathrm{Jul}}$ & Aug & Sep & Oct & Nov & Dec & $\begin{array}{c}\text { Toxicity } \\
\text { Limit }\end{array}$ \\
\hline Aluminum & $<\mathrm{dl}^{\mathrm{b}}$ & $\overline{<\mathrm{dl}}$ & $<\mathrm{dl}$ & $<\mathrm{dl}$ & 0.18 & $<\mathrm{dl}$ & $<\mathrm{dl}$ & $<\mathrm{dl}$ & $<\mathrm{dl}$ & $<\mathrm{dl}$ & $<\mathrm{dl}$ & $<\mathrm{dl}$ & $\bar{N} / \mathrm{A}$ \\
\hline Arsenic & $<\mathrm{dl}$ & $<\mathrm{dl}$ & $<\mathrm{dI}$ & $<\mathrm{dl}$ & 0.002 & $<\mathrm{dl}$ & $<\mathrm{dl}$ & $<\mathrm{dl}$ & $<\mathrm{dl}$ & $<\mathrm{dl}$ & $<\mathrm{dl}$ & $<\mathrm{dl}$ & 5 \\
\hline Barium & 0.09 & 0.11 & 0.08 & 0.10 & 0.09 & 0.11 & 0.07 & 0.08 & 0.07 & 0.13 & 0.01 & 0.10 & 100 \\
\hline Cadmium & $<\mathrm{dl}$ & $<\mathrm{dl}$ & 0.01 & $<\mathrm{dl}$ & $<\mathrm{dl}$ & $<\mathrm{dl}$ & $<$ dl & $<\mathrm{dl}$ & $<$ dl & $<\mathrm{dl}$ & $<\mathrm{dl}$ & $<\mathrm{dl}$ & 1 \\
\hline Chromium & $<\mathrm{dl}$ & 0.005 & $<\mathrm{dl}$ & $<\mathrm{dl}$ & 0.01 & 0.006 & 0.006 & 0.005 & 0.004 & 0.06 & 0.007 & 0.004 & 5 \\
\hline Copper & $<\mathrm{dl}$ & 0.007 & 0.03 & $<\mathrm{dl}$ & 0.04 & $<\mathrm{dl}$ & 0.002 & $<\mathrm{dl}$ & $<\mathrm{dl}$ & $<\mathrm{dl}$ & 0.006 & 0.006 & N/A \\
\hline Mercury & $<\mathrm{dl}$ & $<\mathrm{dl}$ & $<\mathrm{dl}$ & $<\mathrm{dl}$ & $<\mathrm{dl}$ & $<\mathrm{dl}$ & $<\mathrm{dl}$ & $<\mathrm{dl}$ & $<\mathrm{dl}$ & $<\mathrm{dl}$ & $<\mathrm{dl}$ & $<\mathrm{dl}$ & 0.2 \\
\hline Selenium & $<\mathrm{dl}$ & $<$ dl & $<\mathrm{dl}$ & $<\mathrm{dl}$ & $<\mathrm{dl}$ & $<\mathrm{dl}$ & $<\mathrm{dl}$ & $<\mathrm{dl}$ & $<\mathrm{dl}$ & $<\mathrm{dl}$ & 0.002 & $<\mathrm{dl}$ & 1 \\
\hline Silver & $<\mathrm{dl}$ & 0.005 & $<\mathrm{dl}$ & $<\mathrm{dl}$ & $<\mathrm{dl}$ & $<\mathrm{dl}$ & $<\mathrm{dl}$ & $<\mathrm{dl}$ & $<\mathrm{dl}$ & $<\mathrm{dl}$ & $<\mathrm{dl}$ & $<\mathrm{dl}$ & 5 \\
\hline Sodium & 170 & 160 & 160 & 180 & 155 & 177 & 181 & 176 & 158 & 214 & 166 & 196 & N/A \\
\hline Chloride & 288 & 227 & 296 & 268 & 282 & 233 & 262 & 253 & 205 & 278 & 297 & 294 & N/A \\
\hline Fluoride & 0.21 & 0.20 & 0.20 & 0.24 & 0.22 & $<\mathrm{dl}$ & $<\mathrm{dl}$ & $<\mathrm{dl}$ & $<\mathrm{dl}$ & $<\mathrm{dl}$ & $<\mathrm{dl}$ & $<\mathrm{dl}$ & N/A \\
\hline Iron & 0.04 & 0.07 & 0.05 & 0.03 & 0.6 & 0.03 & 0.01 & 0.01 & 0.01 & 0.06 & 0.03 & 0.02 & $N / A$ \\
\hline Lead & $<\mathrm{dl}$ & $<\mathrm{dl}$ & $<\mathrm{dl}$ & $<\mathrm{dl}$ & $<\mathrm{dl}$ & $<\mathrm{dl}$ & $<\mathrm{dl}$ & $<\mathrm{dl}$ & $<\mathrm{dl}$ & $<\mathrm{dl}$ & $<\mathrm{dl}$ & $<\mathrm{dl}$ & 5 \\
\hline Manganese & $<\mathrm{dl}$ & 0.01 & 0.006 & $<\mathrm{dl}$ & 0.009 & $<\mathrm{dl}$ & $<$ dl & 0.0008 & $<\mathrm{dl}$ & 0.05 & 0.002 & $<\mathrm{dl}$ & N/A \\
\hline Nitrate & 4.65 & 4.78 & 4.93 & 4.88 & 4.35 & 5.24 & 5.06 & 4.72 & 4.77 & 5.58 & 4.73 & 5.11 & N/A \\
\hline Nitrite & $<\mathrm{dl}$ & $<\mathrm{dl}$ & $<\mathrm{dl}$ & $<\mathrm{dl}$ & $<\mathrm{dl}$ & $<\mathrm{dl}$ & $<$ dl & $<\mathrm{dl}$ & $<\mathrm{dl}$ & $<\mathrm{dl}$ & $<\mathrm{dl}$ & $<\mathrm{dl}$ & N/A \\
\hline Phosphate & 0.28 & $<\mathrm{d} 1$ & $<\mathrm{dl}$ & $<\mathrm{dl}$ & $<\mathrm{dl}$ & 0.27 & 0.25 & 0.13 & $<\mathrm{dl}$ & $<\mathrm{dl}$ & 0.47 & $<\mathrm{dl}$ & N/A \\
\hline Radium-226 & $<\mathrm{dl}$ & $<\mathrm{dl}$ & $<\mathrm{dl}$ & $<\mathrm{dl}$ & $<\mathrm{dl}$ & $<\mathrm{dl}$ & $<\mathrm{dl}$ & $<\mathrm{dl}$ & $<\mathrm{dl}$ & $<\mathrm{dl}$ & $<\mathrm{dl}$ & $<\mathrm{dl}$ & N/A \\
\hline Radium-228 & $<\mathrm{dl}$ & $<\mathrm{dl}$ & $<\mathrm{dl}$ & $<\mathrm{dl}$ & $<\mathrm{dl}$ & $<\mathrm{dl}$ & $<\mathrm{dl}$ & $<\mathrm{dl}$ & $<\mathrm{dl}$ & $<\mathrm{dl}$ & $<\mathrm{dl}$ & $<\mathrm{dl}$ & $\mathrm{N} / \mathrm{A}$ \\
\hline Sulfate & 23.2 & 27.6 & 27.6 & 27.1 & 26.8 & 27.0 & 28.0 & 26.8 & 26.5 & 28.1 & 52.0 & 27.8 & N/A \\
\hline TDS $^{\mathbf{c}}$ & 690 & 588 & 676 & 743 & 603 & 679 & 619 & 598 & 629 & 897 & 703 & 674 & N/A \\
\hline Conductivity & 1280 & 1300 & 1260 & 1300 & 1260 & -- & 1172 & 1158 & 1142 & 1611 & 1333 & 1330 & N/A \\
\hline pH & 8.4 & 8.4 & 8.4 & 8.6 & 8.4 & 8.2 & 8.6 & 8.5 & 8.7 & 8.4 & 8.8 & 8.5 & 2 to 12.5 \\
\hline $\mathbf{T K N}^{\mathrm{d}}$ & $<\mathrm{dl}$ & $<\mathrm{dl}$ & $<\mathrm{dl}$ & $<\mathrm{dl}$ & $<\mathrm{dl}$ & $<\mathrm{dl}$ & $<\mathrm{dI}$ & $<\mathrm{dl}$ & $<\mathrm{dl}$ & 328 & $<\mathrm{dl}$ & $<\mathrm{dl}$ & N/A \\
\hline
\end{tabular}




\section{Chapter 7. QUALITY ASSURANCE}

\section{Chapter Summary}

Each contractor performing environmental monitoring at the Idaho National Engineering Laboratory maintains a quality assurance program to ensure that results are accurate and reliable (Section 7.1). Laboratories performing analyses for these programs maintain their own quality assurance programs. One part of a laboratory's quality assurance program is participation in a variety of intercomparison programs (Section 7.2), including those administered by the Environmental Measurements Laboratory, the National Institute of Standards and Technology, and the Environmental Protection Agency.

Another measure of the precision of data generated by environmental programs can be gained through the use of duplicate samples. This chapter provides the results of duplicate samples collected by the Environmental Science and Research Foundation and Lockheed Idaho Technologies Company (Section 7.3). Data collected simultaneously at the same location by three different organizations (the Foundation, Lockheed, and the State of Idaho) are also provided for comparison. 


\section{QUALITY ASSURANCE}

\subsection{QUALITY ASSURANCE PROGRAMS}

Quality control and assurance programs were maintained by contractors conducting environmental monitoring, and by laboratories performing environmental analyses, to ensure accurate and reliable results and to maximize data completeness. Elements of typical quality control programs include the following:

- Adherence to peer-reviewed written procedures for sample collection and analytical methods

- Documentation of program changes

- Periodic calibration of instruments with standards traceable to the National Institute of Standards and Technology

- Equipment performance checks

- Routine yield determinations of radiochemical procedures

- Replicate samples to determine precision

- Analysis of blind duplicate and replicate samples

- Analysis of quality control standards in appropriate matrices to test accuracy

- Analysis of reagent blanks to verify that there is no radiochemical contamination during sampling or analysis

- Analysis of blind spike samples (samples containing a known amount of a contaminant) to verify the accuracy of a measurement.

\subsection{LABORATORY INTERCOMPARISON PROGRAMS}

\section{General Information}

Radiological data reported in this document were obtained from several commercial, university, government, and government contractor laboratories, including the Idaho State University Environmental Monitoring Laboratory, the Radiological Measurements Laboratory, the INEL Research Center, the Radiological and Environmental Sciences Laboratory (RESL), Quanterra, Inc., and Accu-Labs Research, Inc. These laboratories participate in a variety of programs to ensure the quality of their analytical data.

\section{Quality Assessment Program (QAP)}

The QAP is administered by the DOE Environmental Measurements Laboratory (EML) in New York. EML prepares quality control samples containing various alpha-, beta-, and gamma-emitting nuclides in water, soil, air filter, vegetation, and tissue media and distributes them to numerous DOE contractor laboratories throughout the country. The program is an interlaboratory comparison in that results from the participants are compared with the experimentally determined results of EML. EML issues QAP Reports twice per year in which the identities of participating laboratories, their results, and comparison to EML results are presented. Results from the QAP program are presented in the following tables 
for four of the laboratories used during 1995 (Tables 7.1-7.4).

\section{National Institute of Standards and Technology (NIST)}

RESL has participated for more than 20 years in a traceability program administered through NIST. NIST prepares several alpha-, beta-, and gamma-emitting standards, generally in liquid media, for analysis by RESL. During previous years, RESL sent samples to other INEL contractors who voluntarily participated in the INEL Intercomparison Program.

\section{EPA Intercomparison Studies Program}

The EPA's Environmental Monitoring Systems Laboratory in Las Vegas, Nevada coordinates an intercomparison program for radionuclides in water. Several laboratories used by contractors performing environmental monitoring at the INEL, including Idaho State University and Quanterra, Inc., participate in this program.

\section{Other Programs}

INEL contractors participate in additional performance evaluation programs, including those adminstered by the International Atomic Energy Agency and the American Society for Testing and Materials. Where possible, contractors use laboratories that are certified by the State of Idaho or certified by another state whose certification is recognized by the state of Idaho.

\section{USGS}

The USGS submits most ground-water samples requiring radioactive analyses to RESL. Samples requiring nonradioactive or organic analyses are submitted to the USGS
National Water Quality Laboratory in Arvada, Colorado, which has been certified by EPA Region 8 for constituents covered by the Safe Drinking Water Act. The INEL USGS Project Office personnel collect, process, and handle all samples according to guidelines specified in a written quality assurance plan for quality of water activities. Quality assurance samples submitted to RESL and the National Water Quality Laboratory consist of at least $10 \%$ of the total number of samples. Data quality is documented through the use of field logbooks, strict chain-of-custody procedures, and a data verification program for analytical results.

USGS Project Office personnel participate in the USGS's National Field Quality Assurance Program which measures the ability of field personnel to accurately measure $\mathrm{pH}$, specific conductance, and alkalinity. Any deficiencies require retesting and, if necessary, corrective action. Technical reviews of the INEL Project Office water-quality program are conducted on two- to three- year intervals by personnel from USGS National Headquarters in Reston, Virginia; Regional Headquarters in Menlo Park, California; and District Headquarters in Boise, Idaho. Written notification of deficiencies are provided to the Project Chief, and corrective actions are required.

\section{Dosimetry}

To verify the quality of the environmental dosimetry program conducted by LITCO, the Operational Dosimetry Unit has participated in eight International Environmental Dosimeter Intercomparison Studies. The Operational Dosimetry Unit's results were within $\pm 10 \%$ of the test exposure values on all intercomparisons. Verification of the environmental dosimetry program is through participation in the Measurement Quality Assurance Program every two years. 
Chapter 7: Quality Assurance

TABLE 7.1

ENVIRONMENTAL MEASUREMENTS LABORATORY (EML) QUALITY ASSESSMENT PROGRAM RESULTS FOR RADIOLOGICAL MEASUREMENTS LABORATORY (RML) [1995]

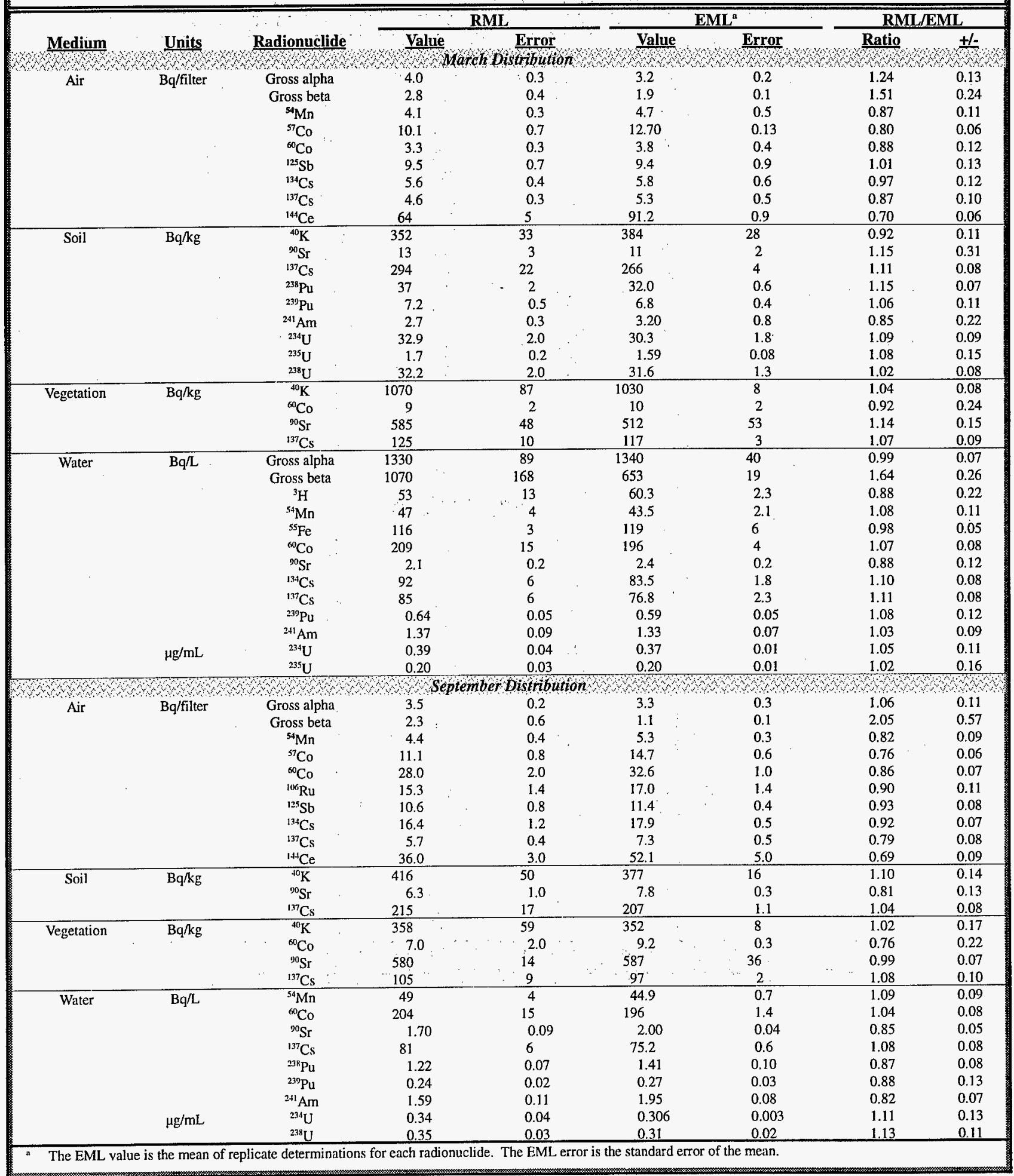


1995 INEL Annual Site Environmental Report

TABLE 7.2

ENVIRONMENTAL MEASUREMENTS LABORATORY (EML) QUALITY ASSESSMENT PROGRAM RESULTS FOR INEL RESEARCH CENTER (IRC) [1995]

\begin{tabular}{|c|c|c|c|c|c|c|c|c|}
\hline \multirow[b]{2}{*}{ Medium } & \multirow[b]{2}{*}{ Units } & \multirow[b]{2}{*}{ Radionuclide } & \multicolumn{2}{|c|}{ IRC } & \multicolumn{2}{|c|}{ EML" } & \multicolumn{2}{|c|}{ IRC/EML } \\
\hline & & & Value & Error & Value & \multirow[t]{2}{*}{ Error } & \multirow{2}{*}{ Ratio } & \multirow{2}{*}{$+1-$} \\
\hline & & & mhn & Distibutit & & & & \\
\hline \multirow[t]{7}{*}{ Air } & \multirow[t]{7}{*}{$\mathrm{Bq} /$ filter } & ${ }^{54} \mathrm{Mn}$ & 3.7 & 0.3 & 4.7 & 0.5 & 0.79 & 0.11 \\
\hline & & ${ }^{57} \mathrm{Co}$ & 9.1 & 0.7 & 12.7 & 0.1 & 0.72 & 0.05 \\
\hline & & ${ }^{60} \mathrm{Co}$ & 3.0 & 0.3 & 3.8 & 0.4 & 0.79 & 0.11 \\
\hline & & ${ }^{125} \mathrm{Sb}$ & 8.6 & 0.9 & 9.4 & 0.9 & 0.92 & 0.13 \\
\hline & & ${ }^{134} \mathrm{Cs}$ & 5.2 & 0.5 & 5.8 & 0.6 & 0.91 & 0.13 \\
\hline & & ${ }^{137} \mathrm{Cs}$ & 4.2 & 0.4 & 5.3 & 0.5 & 0.79 & 0.11 \\
\hline & & ${ }^{144} \mathrm{Ce}$ & 63 & 10 & 91.2 & 0.9 & 0.70 & 0.11 \\
\hline \multirow[t]{5}{*}{ Soil } & \multirow[t]{5}{*}{$\mathrm{Bq} / \mathrm{kg}$} & ${ }^{40} \mathrm{~K}$ & 436 & 164 & 384 & 28 & 1.14 & 0.44 \\
\hline & & ${ }^{137} \mathrm{Cs}$ & 279 & 21 & 266 & 4 & 1.05 & 0.08 \\
\hline & & ${ }^{238} \mathrm{Pu}$ & 33 & 5 & 32.0 & 0.6 & 1.03 & 0.15 \\
\hline & & ${ }^{239} \mathrm{Pu}$ & 7.0 & 0.1 & 6.8 & 0.4 & 1.03 & 0.07 \\
\hline & & ${ }^{241} \mathrm{Am}$ & 2.4 & 0.5 & 3.2 & 0.8 & 0.74 & 0.23 \\
\hline \multirow[t]{3}{*}{ Vegetation } & \multirow[t]{3}{*}{$\mathrm{Bq} / \mathrm{kg}$} & ${ }^{40} \mathrm{~K}$ & 1240 & 293 & 1030 & 8 & 1.20 & 0.29 \\
\hline & & ${ }^{60} \mathrm{Co}$ & 9.5 & 3.0 & 9.6 & 1.7 & 0.99 & 0.36 \\
\hline & & ${ }^{137} \mathrm{Cs}$ & 127 & 23 & 117 & 3 & 1.09 & 0.20 \\
\hline Water & $\mathrm{Bq} / \mathrm{L}$ & ${ }^{54} \mathrm{Mn}$ & 51.2 & 4.7 & 43.5 & 2.1 & 1,18 & 0.12 \\
\hline & & ${ }^{\circ} \mathrm{Co}$ & 227 & 17 & 196 & 3 & 1.16 & 0.09 \\
\hline & & ${ }^{90} \mathrm{Sr}$ & 2.2 & 0.7 & 2.4 & 0.2 & 0.92 & 0.29 \\
\hline & & ${ }^{134} \mathrm{Cs}$ & 98 & 8 & 84 & 2 & 1.17 & 0.10 \\
\hline & & ${ }^{137} \mathrm{Cs}$ & 88 & 7 & 77 & 2 & 1.14 & 0.10 \\
\hline & & ${ }^{230} \mathrm{Pu}$ & 0.66 & 0.11 & 0.59 & 0.05 & 1.12 & 0.21 \\
\hline & & ${ }^{241} \mathrm{Am}$ & 1.55 & 0.29 & 1.33 & 0.07 & 1.17 & 0.23 \\
\hline & $\mu \mathrm{g} / \mathrm{mL}$ & ${ }^{234} \mathrm{U}$ & 0.37 & 0.15 & 0.37 & 0.01 & 0.99 & 0.40 \\
\hline & & ${ }^{235} \mathrm{U}$ & 0.25 & 0.10 & 0.20 & 0.01 & 1.28 & 0.51 \\
\hline क्ष & no & Wrapy,y, & $\mathrm{spl}$ & Distribu & & \$ & 1,20 & Was \\
\hline $\mathrm{Air}$ & $\mathrm{Bq} /$ filter & ${ }^{54} \mathrm{Mn}$ & 4.3 & 0.2 & 5.3 & 0.3 & 0.81 & 0.06 \\
\hline & & ${ }^{57} \mathrm{Co}$ & 10.4 & 0.6 & 14.7 & 0.6 & 0.71 & 0.05 \\
\hline & & ${ }^{60} \mathrm{Co}$ & 27.1 & 0.6 & 32.6 & 1.0 & 0.83 & 0.03 \\
\hline & & ${ }^{106} \mathrm{Ru}$ & 14.6 & 1.8 & 17.0 & 1.4 & 0.86 & 0.13 \\
\hline & & ${ }^{125} \mathrm{Sb}$ & 10.0 & 0.6 & 11.4 & 0.4 & 0.88 & 0.06 \\
\hline & & ${ }^{134} \mathrm{Cs}$ & 15.8 & 0.5 & 17.9 & 0.5 & 0.88 & 0.04 \\
\hline & & ${ }^{137} \mathrm{Cs}$ & 5.2 & 0.4 & 7.3 & 0.5 & 0.72 & 0.07 \\
\hline & & ${ }^{144} \mathrm{Ce}$ & 34.3 & 3.7 & 52.1 & 5.0 & 0.66 & 0.10 \\
\hline Soil & $\mathrm{Bq} / \mathrm{kg}$ & ${ }^{40} \mathrm{~K}$ & 433 & 16 & 377 & 16 & 1.15 & 0.07 \\
\hline & & ${ }^{137} \mathrm{Cs}$ & 233 & 1 & 207 & 1 & 1.13 & 0.01 \\
\hline & & ${ }^{238} \mathrm{Pu}$ & 18.9 & 2.2 & 17.5 & 0.9 . & 1.08 & 0.14 \\
\hline & & ${ }^{239} \mathrm{Pu}$ & 5.7 & 1.0 & 5.2 & 0.1 & 1.10 & 0.19 \\
\hline & & ${ }^{241} \mathrm{Am}$ & 1.7 & 0.3 & 1.8 & 0.1 & 0.97 & 0.20 \\
\hline Vegetation & $\mathrm{Bq} / \mathrm{kg}$ & ${ }^{40} \mathrm{~K}$ & 353 & 2 & 3.52 & 8 & 1.00 & 0.02 \\
\hline & & ${ }^{60} \mathrm{Co}$ & 9 & 2 & 9.2 & 0.3 & 0.97 & 0.22 \\
\hline & & ${ }^{137} \mathrm{Cs}$ & 106.0 & 0.6 & 97 & 2 & 1.09 & 0.02 \\
\hline Water & $\mathrm{Bq} / \mathrm{L}$ & Gross alpha & 1460 & 205 & 1310 & 100 & 1.12 & 0.18 \\
\hline & & Gross beta & 784 & 102 & 410 & 40 & 1.91 & 0.31 \\
\hline & & ${ }^{54} \mathrm{Mn}$ & 52 & 1 & 44.9 & 0.7 & 1.17 & 0.03 \\
\hline & & ${ }^{60} \mathrm{Co}$ & 219 & 3 & 196 & 1 & 1.12 & 0.02 \\
\hline & & ${ }^{90} \mathrm{Sr}$ & 1.66 & 0.40 & 2.00 & 0.04 & 0.83 & 0.20 \\
\hline & & ${ }^{137} \mathrm{Cs}$ & 82 & 1 & 75 & 1 & 1.09 & 0.01 \\
\hline & & ${ }^{238} \mathrm{Pu}$ & 1.39 & 0.27 & 1.41 & 0.10 & 0.99 & 0.20 \\
\hline & & ${ }^{239} \mathrm{Pu}$ & 0.27 & 0.08 & 0.27 & 0.03 & 0.99 & 0.32 \\
\hline & & ${ }^{241} \mathrm{Am}$ & 1.85 & 0.18 & 1.95 & 0.08 & 0.95 & 0.10 \\
\hline
\end{tabular}


Chapter 7: Quality Assurance

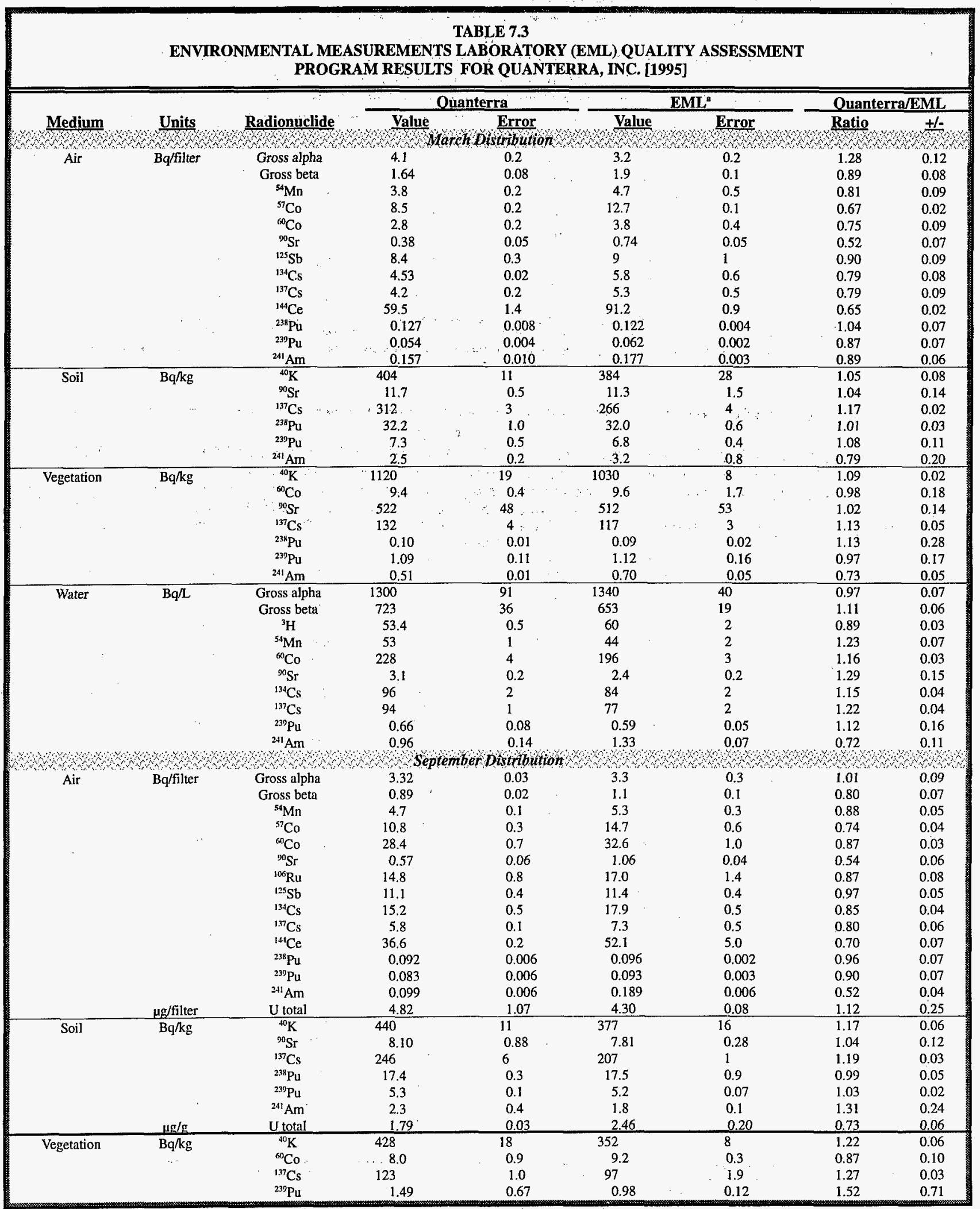


1995 INEL Annual Site Environmental Report

\begin{tabular}{|c|c|c|c|c|c|c|c|c|}
\hline \multicolumn{9}{|c|}{$\begin{array}{l}\text { TABLE 7.3 (Cont.) } \\
\text { ENVIRONMENTAL MEASUREMENTS LABORATORY (EML) QUALITY ASSESSMENT } \\
\text { PROGRAM RESULTS FOR QUANTERRA, INC. [1995] }\end{array}$} \\
\hline \multirow{4}{*}{$\frac{\text { Medium }}{\text { Vegetation }}$} & \multirow{4}{*}{$\frac{\text { Units }}{\mathrm{Bq} / \mathrm{kg}}$} & \multirow{4}{*}{$\frac{\text { Radionuclide }}{{ }^{241} \mathrm{Am}}$} & \multicolumn{2}{|c|}{ Ouanterra } & \multicolumn{2}{|c|}{ EML" } & \multicolumn{2}{|c|}{ Ouanterra/EML } \\
\hline & & & Value & Error & Value & Error & Ratio & $+1-$ \\
\hline & & & $\overline{0.51}$ & 0.07 & $\overline{0.53}$ & 0.04 & 0.96 & 0.15 \\
\hline & & & 0.37 & 0.01 & 0.43 & 0.01 & 0.85 & 0.03 \\
\hline Water & $\mathrm{Bg} / \mathrm{L}$ & Gross alpha & 1090 & 125 & 1310 & 100 & 0.83 & 0.12 \\
\hline & & Gross beta & 367 & 64 & 410 & 40 & 0.90 & 0.18 \\
\hline & & ${ }^{3} \mathrm{H}$ & 138 & 11 & 168 & 35 & 0.82 & 0.18 \\
\hline & & ${ }^{54} \mathrm{Mn}$ & 60 & 0.6 & 44.9 & 0.7 & 1.34 & 0.03 \\
\hline & & ${ }^{60} \mathrm{Co}$ & 234 & 9 & 196 & 1 & 1.19 & 0.05 \\
\hline & & ${ }^{137} \mathrm{Cs}$ & 94 & 4 & 75.2 & 0.6 & 1.25 & 0.05 \\
\hline & & ${ }^{238} \mathrm{Pu}$ & 1.34 & 0.10 & 1.41 & 0.10 & 0.95 & 0.09 \\
\hline & & ${ }^{239} \mathrm{Pu}$ & 0.31 & 0.04 & 0.27 & 0.03 & 1.14 & 0.19 \\
\hline & & ${ }^{241} \mathrm{Am}$ & 1.68 & 0.12 & 1.95 & 0.08 & 0.86 & 0.07 \\
\hline
\end{tabular}

\begin{tabular}{|c|c|c|c|c|c|c|c|c|}
\hline \multicolumn{9}{|c|}{$\begin{array}{l}\text { TABLE } 7.4 \\
\text { ENVIRONMENTAL MEASUREMENTS LABORATORY (EML) QUALITY ASSESSMENT PROGRAM RESULTS } \\
\text { FOR RADIOLOGICAL AND ENVIRONMENTAL SCIENCES LABORATORY (RESL) [1995] }\end{array}$} \\
\hline \multirow{15}{*}{$\begin{array}{c}\text { Medium } \\
\text { Air }\end{array}$} & \multirow{4}{*}{$\begin{array}{l}\text { Units } \\
\text { Bq/filter }\end{array}$} & \multirow{4}{*}{$\begin{array}{l}\text { Radionuclide } \\
{ }^{54 \mathrm{Mn}} \\
{ }^{57} \mathrm{Co}\end{array}$} & \multicolumn{2}{|c|}{ RESL } & \multicolumn{2}{|c|}{ EML $^{\mathrm{a}}$} & \multicolumn{2}{|c|}{ RESL/EML } \\
\hline & & & Value & Error & Value & Error & Ratio & $\frac{+1-}{x-1}$ \\
\hline & & & 4.2 & 0.7 & 5.3 & 0.3 & 0.79 & 0.14 \\
\hline & & & 10.3 & 0.6 & 14.7 & 0.6 & 0.70 & 0.05 \\
\hline & & ${ }^{60} \mathrm{Co}$ & 28 & 1 & 33 & 1 & 0.84 & 0.04 \\
\hline & & ${ }^{20} \mathrm{Sr}$ & 1.16 & 0.05 & 1.06 & 0.04 & 1.09 & 0.06 \\
\hline & & ${ }^{106} \mathrm{Ru}$ & 14.0 & 5.0 & 17.0 & 1.4 & 0.82 & 0.30 \\
\hline & & ${ }^{125} \mathrm{Sb}$ & 11.0 & 2.0 & 11.4 & 0.4 & 0.97 & 0.18 \\
\hline & & ${ }^{134} \mathrm{Cs}$ & 15.1 & 0.9 & 17.9 & 0.5 & 0.84 & 0.06 \\
\hline & & 嘼 $\mathrm{Cs}$ & 5.6 & 0.6 & 7.3 & 0.5 & 0.77 & 0.10 \\
\hline & & ${ }^{144} \mathrm{Ce}$ & 34.0 & 4.0 & 52.1 & 5.0 & 0.65 & 0.10 \\
\hline & & ${ }^{241} \mathrm{Am}$ & 0.21 & 0.01 & 0.189 & 0.006 & 1.11 & 0.06 \\
\hline & $\mu \mathrm{g} / \mathrm{filter}$ & ${ }^{294} \mathrm{U}$ & 0.060 & 0.003 & 0.052 & 0.001 & 1.16 & 0.06 \\
\hline & & ${ }^{235} \mathrm{U}$ & 0.004 & 0.001 & 0.002 & 0.000 & 2.00 & 0.32 \\
\hline & & ${ }^{238} \mathrm{U}$ & 0.059 & 0.003 & 0.053 & 0.002 & 1.11 & 0.07 \\
\hline Soil & $\mathrm{Bq} / \mathrm{kg}_{\mathrm{g}}$ & ${ }^{40} \mathrm{~K}$ & 393 & 35 & 377 & 16 & 1.04 & 0.10 \\
\hline & & ${ }^{20} \mathrm{Sr}$ & 9.0 & 3.0 & 7.8 & 0.3 & 1.15 & 0.39 \\
\hline & & ${ }^{137} \mathrm{Cs}$ & 232 & 10 & 207 & 1.1 & 1.12 & 0.05 \\
\hline & & ${ }^{238} \mathrm{Pu}$ & 18.2 & 0.8 & 17.5 & 0.9 & 1.04 & 0.07 \\
\hline & & ${ }^{239} \mathrm{Pu}$ & 5.3 & 0.3 & 5.2 & 0.07 & 1.03 & 0.06 \\
\hline & & ${ }^{241} \mathrm{Am}$ & 1.7 & 0.2 & 1.8 & 0.1 & 0.98 & 0.11 \\
\hline & $\mu g$ ffilter & ${ }^{234} \mathrm{U}$ & 33 & 1 & 30 & 2 & 1.11 & 0.10 \\
\hline & & ${ }^{335} \mathrm{U}$ & 1.4 & 0.1 & 1.5 & 0.2 & 0.96 & 0.15 \\
\hline & & ${ }^{238} \mathrm{U}$ & 33 & 1.1 & 30 & 2 & 1.07 & 0.08 \\
\hline Vegetation & $\mathrm{Bq} / \mathrm{kg}$ & ${ }^{40} \mathrm{~K}$ & 329 & 50 & 352 & 8 & 0.94 & 0.14 \\
\hline & & ${ }^{60} \mathrm{Co}$ & 8 & 2 & 9.2 & 0.3 & 0.87 & 0.22 \\
\hline & & ${ }^{90} \mathrm{Sr}$ & 568 & 15 & 587 & 36 & 0.97 & 0.07 \\
\hline & & ${ }^{137} \mathrm{Cs}$ & 100 & 6 & 97 & 2 & 1.03 & 0.07 \\
\hline & & ${ }^{230} \mathrm{Pu}$ & 0.85 & 0.07 & 0.98 & 0.12 & 0.87 & 0.87 \\
\hline & & ${ }^{241} \mathrm{Am}$ & 0.54 & 0.06 & 0.53 & 0.04 & 1.01 & 0.14 \\
\hline Water & $\mathrm{Bq} / \mathrm{L}$ & ${ }^{3} \mathrm{H}$ & 153 & 6 & 168 & 35 & 0.91 & 0.19 \\
\hline & & ${ }^{54} \mathrm{Mn}$ & 51.0 & 3.0 & 44.9 & 0.7 & 1.14 & 0.07 \\
\hline & & ${ }^{s 5} \mathrm{Fe}$ & 123 & 2 & 101 & 4 & 1.22 & 0.05 \\
\hline & & ${ }^{60} \mathrm{Co}$ & 207 & 7 & 196 & 1 & 1.06 & 0.04 \\
\hline & & ${ }^{10} \mathrm{Sr}$ & 2.1 & 0.2 & 2.00 & 0.04 & 1.05 & 0.10 \\
\hline & & ${ }^{137} \mathrm{Cs}$ & 80 & 4 & 75.2 & 0.6 & 1.06 & 0.05 \\
\hline & & ${ }^{238} \mathrm{Pu}$ & 1.37 & 0.06 & 1.41 & 0.10 & 0.97 & 0.08 \\
\hline & & ${ }^{239} \mathrm{Pu}$ & 0.28 & 0.02 & 0.27 & 0.03 & 1.03 & 0.15 \\
\hline & & ${ }^{241} \mathrm{Am}$ & 1.76 & 0.07 & 1.95 & 0.08 & 0.90 & 0.05 \\
\hline
\end{tabular}




\subsection{DATA PRECISION AND VERIFICATION}

\section{Duplicate Sampling}

As a measure of the quality of data collected, both the Environmental Science and Research Foundation and LITCO used a variety of quality control samples of different media. Quality control samples include duplicate samples (separate samples taken at the same time), split samples (two portions of a sample that are analyzed separately), and spike samples (samples to which a known amount of a contaminant is added).

Both organizations maintained duplicate air samplers at two locations during 1995. The Foundation operated these samplers at Atomic City and Rexburg and the Lockheed samplers were at CFA and TAN (Table 7.5). Filters from these two samplers were collected and analyzed in the same manner as filters from regular air samplers.

\section{Independent Data Comparisons}

Another measure of data quality can be made by comparing data collected simultaneously by different organizations. In 1995, there were three organizations, the Foundation, LITCO, and the State of Idaho performing environmental surveillance in conjunction with the INEL. At three sampling locations, the distant location of Craters of the Moon and on the INEL at EFS and Van Buren Avenue, all three of these organizations collected air monitoring data throughout 1995. Data from these three sampling locations for gross alpha and gross beta are shown in Tables 7.6 and 7.7. The three organizations maintain slightly different collection and analysis schedules.

The Foundation also collects quarterly samples of drinking and surface water at five locations in the Magic Valley area jointly with the State Oversight Program. Table 7.8 contains results from analysis of 1995 samples from these locations. 
1995 INEL Annual Site Environmental Report

TABLE 7.5

COMPARISON OF DUPLICATE AIR MONITORING RESULTS (1995) Environmental Science and Research Foundation Data

\begin{tabular}{|c|c|c|c|c|c|c|c|c|}
\hline & \multicolumn{4}{|c|}{ Gross Alpha $\left(10^{-15} \mu \mathrm{Ci} / \mathrm{mL}\right)^{a}$} & \multicolumn{4}{|c|}{ Gross Beta $\left(10^{-15} \mu \mathrm{Ci} / \mathrm{mL}\right)^{a}$} \\
\hline & \multicolumn{2}{|c|}{ Rexburg } & \multicolumn{2}{|c|}{ Atomic City } & \multicolumn{2}{|c|}{ Rexburg } & \multicolumn{2}{|c|}{ Atomic City } \\
\hline Month & Sampler & Duplicate & Sampler & Duplicate & Sampler & Duplicate & Sampler & Duplicate \\
\hline January & $0.7 \pm 0.5$ & $1.1 \pm 0.6$ & $0.7 \pm 0.3$ & $0.5 \pm 1.1$ & $26 \pm 13$ & $28 \pm 18$ & $29 \pm 15$ & $30 \pm 15$ \\
\hline February & $2.3 \pm 2.4$ & $1.6 \pm 0.8$ & $1.1 \pm 1.4$ & $1.0 \pm 1.0$ & $29 \pm 15$ & $33 \pm 15$ & $37 \pm 10$ & $37 \pm 13$ \\
\hline March & $1.1 \pm 0.9$ & $0.8 \pm 1.4$ & $0.2 \pm 0.8$ & $0.6 \pm 1.3$ & $18 \pm 6$ & $24 \pm 12$ & $18 \pm 7$ & $18 \pm 8$ \\
\hline April & $1.3 \pm 2.2$ & $1.4 \pm 1.2$ & $0.8 \pm 0.8$ & $0.8 \pm 0.5$ & $17 \pm 6$ & $19 \pm 7$ & $25 \pm 19$ & $18 \pm 7$ \\
\hline May & $1.3 \pm 0.9$ & $0.8 \pm 1.9$ & $0.9 \pm 1.0$ & $1.7 \pm 0.9$ & $20 \pm 8$ & $19 \pm 14$ & $22 \pm 11$ & $20 \pm 8$ \\
\hline June & $1.0 \pm 0.2$ & $1.6 \pm 1.6$ & $0.9 \pm 1.1$ & $1.3 \pm 0.7$ & $21 \pm 4$ & $21 \pm 9$ & $18 \pm 1$ & $23 \pm 7$ \\
\hline July & $2.7 \pm 0.7$ & $2.2 \pm 0.8$ & $2.3 \pm 1.3$ & $2.6 \pm 1.3$ & $28 \pm 6$ & $27 \pm 5$ & $29 \pm 5$ & $30 \pm 10$ \\
\hline August & $1.9 \pm 2.1$ & $1.7 \pm 0.9$ & $2.2 \pm 1.1$ & $2.0 \pm 1.5$ & $38 \pm 26$ & $38 \pm 32$ & $38 \pm 33$ & $45 \pm 47$ \\
\hline September & $1.6 \pm 1.5$ & $2.3 \pm 2.0$ & $2.7 \pm 2.0$ & $1.7 \pm 1.8$ & $32 \pm 11$ & $33 \pm 8$ & $30 \pm 5$ & $33 \pm 13$ \\
\hline October & $2.5 \pm 1.0$ & $2.4 \pm 1.5$ & $1.5 \pm 0.4$ & $1.7 \pm 1.1$ & $21 \pm 5$ & $25 \pm 5$ & $23 \pm 6$ & $25 \pm 5$ \\
\hline November & $1.8 \pm 1.3$ & $1.7 \pm 1.5$ & $1.6 \pm 1.6$ & $2.4 \pm 1.2$ & $28 \pm 16$ & $27 \pm 13$ & $29 \pm 14$ & $25 \pm 18$ \\
\hline December & $1.3 \pm 1.8$ & $1.7 \pm 1.1$ & $0.9 \pm 1.6$ & $0.6 \pm 1.5$ & $30 \pm 31$ & $27 \pm 28$ & $28 \pm 28$ & $26 \pm 36$ \\
\hline Annual & $1.7 \pm 0.3$ & $1.6 \pm 0.3$ & $1.3 \pm 0.3$ & $1.4 \pm 0.3$ & $25 \pm 3$ & $27 \pm 3$ & $27 \pm 3$ & $27 \pm 4$ \\
\hline \multicolumn{9}{|c|}{ LITCO Data } \\
\hline & \multicolumn{4}{|c|}{ Gross Alpha $\left(10^{-15} \mu \mathrm{Ci} / \mathrm{mL}\right)^{\mathrm{a}}$} & \multicolumn{4}{|c|}{ Gross Beta $\left(10^{-15} \mu \mathrm{Ci} / \mathrm{mL}\right)^{\mathrm{a}}$} \\
\hline & \multicolumn{2}{|c|}{ CFA } & \multicolumn{2}{|c|}{ TAN } & \multicolumn{2}{|c|}{ CFA } & \multicolumn{2}{|c|}{$\begin{array}{r}\text { TAN } \\
\end{array}$} \\
\hline Month & Sampler & Duplicate & Sampler & Duplicate & Sampler & Duplicate & Sampler & Duplicate \\
\hline January & $0.1 \pm 1.4$ & $0.2 \pm 1.2$ & $0.9 \pm 1.4$ & $0.3 \pm 0.7$ & $21 \pm 7$ & $17 \pm 7$ & $22 \pm 10$ & $22 \pm 9$ \\
\hline February & $0.7 \pm 2.7$ & $1.0 \pm 1.3$ & $0.8 \pm 0.8$ & $1.1 \pm 0.7$ & $32 \pm 15$ & $27 \pm 13$ & $30 \pm 12$ & $27 \pm 15$ \\
\hline March & $0.0 \pm 0.9$ & $0.1 \pm 1.9$ & $1.4 \pm 0.7$ & $0.0 \pm 0.8$ & $13 \pm 6$ & $13 \pm 10$ & $14 \pm 9$ & $14 \pm 7$ \\
\hline April & $0.1 \pm 1.1$ & $0.7 \pm 1.5$ & $0.7 \pm 0.7$ & $0.7 \pm 1.1$ & $14 \pm 7$ & $13 \pm 6$ & $16 \pm 7$ & $14 \pm 7$ \\
\hline May & $0.6 \pm 1.4$ & $0.9 \pm 0.9$ & $0.4 \pm 0.9$ & $0.5 \pm 1.1$ & $15 \pm 9$ & $14 \pm 10$ & $16 \pm 9$ & $13 \pm 12$ \\
\hline June & $0.6 \pm 2.0$ & $0.2 \pm 1.2$ & $0.5 \pm 1.0$ & $0.2 \pm 1.1$ & $16 \pm 4$ & $12 \pm 3$ & $14 \pm 6$ & $14 \pm 1$ \\
\hline July & $1.6 \pm 0.6$ & $0.7 \pm 1.2$ & $0.7 \pm 0.5$ & $1.2 \pm 0.9$ & $21 \pm 4$ & $18 \pm 7$ & $22 \pm 6$ & $17 \pm 7$ \\
\hline August & $1.3 \pm 2.7$ & $0.6 \pm 0.3$ & $0.5 \pm 0.7$ & $0.7 \pm 1.8$ & $20 \pm 7$ & $22 \pm 5$ & $22 \pm 6$ & $21 \pm 7$ \\
\hline September & $0.9 \pm 0.7$ & $1.0 \pm 1.1$ & $1.1 \pm 0.7$ & $0.7 \pm 0.6$ & $28 \pm 7$ & $25 \pm 2$ & $24 \pm 7$ & $22 \pm 6$ \\
\hline October & $0.7 \pm 1.7$ & $1.2 \pm 0.8$ & $0.1 \pm 0.8$ & $0.6 \pm 0.8$ & $18 \pm 2$ & $16 \pm 4$ & $19 \pm 4$ & $18 \pm 6$ \\
\hline November & $0.5 \pm 2.4$ & $0.4 \pm 0.9$ & $1.1 \pm 1.5$ & $0.5 \pm 1.1$ & $16 \pm 23$ & $15 \pm 15$ & $25 \pm 13$ & $24 \pm 19$ \\
\hline December & $0.3 \pm 1.9$ & $-0.2 \pm 0.7$ & $0.3 \pm 1.3$ & $0.1 \pm 1.6$ & $24 \pm 30$ & $16 \pm 12$ & $28 \pm 25$ & $16 \pm 6$ \\
\hline Annual & $0.6 \pm 0.3$ & $0.5 \pm 0.2$ & $0.7 \pm 0.2$ & $0.6 \pm 0.2$ & $20 \pm 3$ & $17 \pm 2$ & $21 \pm 2$ & $19 \pm 2$ \\
\hline
\end{tabular}


Chapter 7: Quality Assurance

\section{TABLE 7.6 COMPARISON OF FOUNDATION (F), LITCO (L) AND STATE OF IDAHO (S) AIR MONITORING RESULTS} (1995)

\begin{tabular}{|c|c|c|c|c|c|c|c|c|c|}
\hline \multirow{3}{*}{$\begin{array}{l}\text { Week } \\
\text { Ending }\end{array}$} & \multicolumn{9}{|c|}{ Gross Alpha $\left(10^{-15} \mu \mathrm{Cl} / \mathrm{mL}\right)^{n}$} \\
\hline & \multicolumn{3}{|c|}{ Craters of the Moon } & \multicolumn{3}{|c|}{ EFS } & \multicolumn{3}{|c|}{ Van Buren } \\
\hline & $F$ & $L$ & $\mathrm{~s}$ & $\mathbf{F}$ & $\mathrm{L}$ & $\mathrm{s}$ & $F$ & $\mathbf{L}$ & $\mathbf{s}$ \\
\hline $1 / 7$ & $1.2 \pm 1.2$ & $0.4 \pm 2.0$ & $-1 \pm 2$ & $1.7 \pm 1.3$ & $0.4 \pm 1.6$ & $1 \pm 1$ & $1.5 \pm 1.4$ & $0.1 \pm 2.0$ & $3 \pm 4$ \\
\hline $1 / 13$ & $0.7 \pm 1.2$ & $1.5 \pm 1.6$ & $0.0 \pm 2.3$ & $0.3 \pm 1.0$ & $0.7 \pm 1.2$ & $0.0 \pm 1.9$ & $1.6 \pm 1.7$ & $1.1 \pm 1.6$ & $2.1 \pm 3.5$ \\
\hline $1 / 20$ & $0.3 \pm 0.7$ & $-0.3 \pm 1.6$ & $0.7 \pm 2.5$ & $0.7 \pm 0.8$ & $0.2 \pm 1.4$ & $0.3 \pm 2.1$ & $0.2 \pm 0.7$ & $-1.3 \pm 1.6$ & $-0.5 \pm 2.4$ \\
\hline $1 / 27$ & $-0.7 \pm 1.4$ & $-0.6 \pm 1.2$ & $0.7 \pm 2.8$ & $0.5 \pm 1.7$ & $-0.1 \pm 1.2$ & $-0.3 \pm 1.7$ & $0.2 \pm 1.3$ & $-0.3 \pm 1.4$ & $0.0 \pm 2.7$ \\
\hline $2 / 3$ & $-0.3 \pm 1.2$ & $0.7 \pm 1.4$ & $-1.5 \pm 1.8$ & $0.6 \pm 1.3$ & $0.1 \pm 1.2$ & $1.3 \pm 2.3$ & $1.8 \pm 1.8$ & $0.9 \pm 1.6$ & $-1.8 \pm 1.9$ \\
\hline $2 / 10$ & $1.5 \pm 1.7$ & $-0.7 \pm 1.6$ & $2.2 \pm 3.0$ & $1.7 \pm 1.6$ & $2.3 \pm 1.8$ & $1.1 \pm 2.3$ & $0.6 \pm 1.6$ & $2.1 \pm 2.0$ & $3.2 \pm 3.8$ \\
\hline $2 / 17$ & $0.0 \pm 1.3$ & $1.9 \pm 1.8$ & $-0.5 \pm 2.0$ & $0.5 \pm 1.2$ & $-0.2 \pm 1.2$ & $-0.3 \pm 1.7$ & $0.6 \pm 1.6$ & $0.2 \pm 1.6$ & $2.1 \pm 3.5$ \\
\hline $2 / 24$ & $1.1 \pm 1.3$ & $1.0 \pm 2.0$ & $-1.0 \pm 1.8$ & $2.3 \pm 1.3$ & $-0.4 \pm 1.4$ & $1.1 \pm 2.3$ & $0.1 \pm 1.0$ & $-1.1 \pm 1.8$ & $2.1 \pm 3.5$ \\
\hline $3 / 3$ & $3.3 \pm 1.7$ & $1.1 \pm 1.6$ & $0.2 \pm 2.5$ & $1.7 \pm 1.2$ & $1.4 \pm 1.4$ & $2.6 \pm 2.8$ & $1.9 \pm 1.6$ & $1.0 \pm 2.0$ & $3.2 \pm 3.8$ \\
\hline $3 / 10$ & $-0.9 \pm 1.4$ & $0.1 \pm 1.4$ & $1.2 \pm 2.8$ & $0.4 \pm 1.4$ & $0.4 \pm 1.4$ & $0.7 \pm 2.1$ & $-0.5 \pm 1.6$ & $0.3 \pm 1.8$ & $-0.5 \pm 2.4$ \\
\hline $3 / 17$ & $-0.1 \pm 1.1$ & $0.9 \pm 1.4$ & $0.2 \pm 2.5$ & $1.2 \pm 1.3$ & $1.4 \pm 1.4$ & $0.7 \pm 2.1$ & $-0.1 \pm 1.3$ & $-0.1 \pm 1.6$ & $-1.3 \pm 2.4$ \\
\hline $3 / 24$ & $0.3 \pm 1.3$ & $0.0 \pm 1.6$ & $0.5 \pm 2.8$ & $0.8 \pm 1.3$ & $-0.4 \pm 1.4$ & $-0.7 \pm 1.5$ & $0.4 \pm 1.5$ & $-0.7 \pm 1.8$ & $-0.5 \pm 2.4$ \\
\hline $3 / 31$ & $-0.1 \pm 0.8$ & $0.5 \pm 1.6$ & $0.0 \pm 2.3$ & $0.8 \pm 1.1$ & $-0.5 \pm 1.4$ & $0.7 \pm 2.1$ & $1.6 \pm 1.5$ & $0.8 \pm 1.8$ & $2.1 \pm 3.5$ \\
\hline $4 / 7$ & $1.3 \pm 1.5$ & $0.6 \pm 1.8$ & $1.2 \pm 3.0$ & $2.4 \pm 1.6$ & $-0.4 \pm 2.2$ & $1.6 \pm 2.6$ & $2.4 \pm 2.0$ & $0.9 \pm 2.2$ & $2.1 \pm 3.8$ \\
\hline $4 / 14$ & $\mathrm{NS}^{\mathrm{b}}$ & $0.0 \pm 1.4$ & $1.2 \pm 5.1$ & $0.3 \pm 1.2$ & $0.0 \pm 1.0$ & $0.1 \pm 2.1$ & $-0.7 \pm 1.3$ & $2.0 \pm 2.8$ & $0.8 \pm 3.2$ \\
\hline $4 / 21$ & $0.0 \pm 1.1$ & $0.9 \pm 1.8$ & $2.5 \pm 3.8$ & $0.7 \pm 1.1$ & $1.4 \pm 1.6$ & $0.9 \pm 2.3$ & $1.7 \pm 1.6$ & $0.7 \pm 1.6$ & $2.6 \pm 3.8$ \\
\hline $4 / 28$ & $0.1 \pm 1.4$ & $0.6 \pm 1.4$ & $0.2 \pm 2.8$ & $-0.4 \pm 1.2$ & $1.1 \pm 1.4$ & $1.6 \pm 2.6$ & $0.1 \pm 1.7$ & $-0.1 \pm 1.6$ & $0.2 \pm 3.2$ \\
\hline $5 / 5$ & $0.7 \pm 1.3$ & $0.9 \pm 1.6$ & $2.5 \pm 3.5$ & $-0.1 \pm 1.0$ & $0.4 \pm 1.6$ & $-0.5 \pm 1.7$ & $-0.3 \pm 1.2$ & $0.7 \pm 1.8$ & $-1.3 \pm 2.4$ \\
\hline $5 / 12$ & $0.0 \pm 1.0$ & $0.9 \pm 1.6$ & $0.2 \pm 2.8$ & $0.8 \pm 1.1$ & $0.7 \pm 1.6$ & $-0.1 \pm 2.1$ & $0.8 \pm 1.3$ & $1.6 \pm 2.0$ & $1.0 \pm 3.5$ \\
\hline $5 / 19$ & $-0.5 \pm 1.2$ & $1.2 \pm 1.6$ & $2.7 \pm 3.5$ & $1.1 \pm 1.5$ & $0.2 \pm 1.2$ & $-0.5 \pm 1.7$ & $-0.1 \pm 1.5$ & $-0.1 \pm 1.6$ & $-0.2 \pm 2.9$ \\
\hline $5 / 26$ & $2.4 \pm 1.6$ & $1.3 \pm 1.8$ & $1.5 \pm 2.5$ & $1.6 \pm 1.4$ & $-0.7 \pm 1.4$ & $1.1 \pm 2.3$ & $1.1 \pm 1.2$ & $1.3 \pm 2.0$ & $0.2 \pm 2.4$ \\
\hline $6 / 2$ & $0.6 \pm 0.9$ & $1.1 \pm 1.6$ & $2.0 \pm 4.6$ & $0.9 \pm 1.0$ & $1.7 \pm 1.4$ & $0.5 \pm 1.9$ & $1.1 \pm 1.0$ & $-0.3 \pm 1.6$ & $0.8 \pm 2.9$ \\
\hline $6 / 9$ & $1.1 \pm 1.0$ & $0.7 \pm 1.4$ & $0.2 \pm 2.5$ & $-0.1 \pm 0.5$ & $0.4 \pm 1.4$ & $-0.5 \pm 2.1$ & $0.7 \pm 0.8$ & $0.5 \pm 1.6$ & $1.3 \pm 4.3$ \\
\hline $6 / 16$ & $0.4 \pm 1.0$ & $0.0 \pm 1.4$ & $0.2 \pm 2.5$ & $1.2 \pm 1.2$ & $0.3 \pm 1.4$ & $0.9 \pm 2.1$ & $1.1 \pm 1.2$ & $0.6 \pm 1.8$ & $1.0 \pm 2.7$ \\
\hline $6 / 23$ & $0.3 \pm 1.2$ & $0.4 \pm 1.4$ & NS & $-0.6 \pm 0.8$ & $1.0 \pm 1.4$ & $-0.7 \pm 1.3$ & $0.6 \pm 1.3$ & $0.5 \pm 1.8$ & $-0.8 \pm 2.7$ \\
\hline $6 / 30$ & $0.6 \pm 0.8$ & $-0.1 \pm 1.4$ & $0.2 \pm 2.8$ & $2.1 \pm 1.3$ & $-0.2 \pm 1.4$ & $-0.7 \pm 1.3$ & $1.5 \pm 1.2$ & $0.3 \pm 1.8$ & NS \\
\hline $7 / 7$ & $2.9 \pm 2.0$ & $0.0 \pm 1.8$ & $-0.2 \pm 2.8$ & $2.8 \pm 1.6$ & $1.7 \pm 1.8$ & $-0.1 \pm 1.5$ & $2.0 \pm 1.5$ & $2.1 \pm 2.2$ & $-0.5 \pm 2.1$ \\
\hline $7 / 14$ & $1.5 \pm 1.4$ & $0.1 \pm 1.8$ & NS & $1.0 \pm 1.2$ & $0.5 \pm 1.6$ & $0.5 \pm 2.3$ & $3.1 \pm 2.0$ & $2.1 \pm 2.2$ & $2.1 \pm 3.2$ \\
\hline $7 / 21$ & $1.4 \pm 1.2$ & $1.5 \pm 1.8$ & $-0.5 \pm 2.0$ & $1.2 \pm 1.1$ & $0.0 \pm 1.2$ & $0.5 \pm 1.9$ & $2.5 \pm 1.7$ & $-0.3 \pm 1.6$ & $0.2 \pm 2.7$ \\
\hline $7 / 28$ & $1.8 \pm 1.3$ & $1.1 \pm 1.6$ & $2.5 \pm 8.9$ & $1.6 \pm 1.2$ & $1.4 \pm 1.4$ & $-0.7 \pm 1.3$ & $0.9 \pm 1.2$ & $0.7 \pm 1.8$ & $0.2 \pm 3.2$ \\
\hline $8 / 4$ & $2.0 \pm 1.4$ & $2.2 \pm 1.6$ & $1.5 \pm 5.6$ & $1.2 \pm 1.1$ & $1.4 \pm 1.4$ & $1.5 \pm 2.3$ & $2.8 \pm 1.9$ & $1.3 \pm 1.8$ & $-1.0 \pm 2.1$ \\
\hline $8 / 11$ & $2.0 \pm 1.4$ & $1.7 \pm 1.6$ & $1.0 \pm 2.8$ & $0.9 \pm 1.0$ & $2.0 \pm 1.6$ & $0.1 \pm 1.7$ & $0.8 \pm 1.2$ & $2.1 \pm 2.0$ & $-0.2 \pm 2.4$ \\
\hline $8 / 18$ & $1.2 \pm 1.1$ & $0.9 \pm 1.4$ & $-0.5 \pm 2.0$ & $0.9 \pm 1.0$ & $1.7 \pm 1.6$ & $1.1 \pm 2.1$ & $2.0 \pm 1.6$ & $0.8 \pm 1.6$ & $0.8 \pm 2.7$ \\
\hline $8 / 25$ & $0.8 \pm 1.0$ & $0.0 \pm 1.4$ & $-0.2 \pm 3.8$ & $1.2 \pm 1.1$ & $-0.6 \pm 1.4$ & $-0.1 \pm 1.7$ & $2.1 \pm 1.8$ & $0.9 \pm 2.0$ & $\overline{\mathrm{NS}}$ \\
\hline $9 / 1$ & $0.8 \pm 1.0$ & $0.3 \pm 1.4$ & $2.2 \pm 3.0$ & $2.3 \pm 1.5$ & $0.3 \pm 1.0$ & $-0.5 \pm 1.5$ & $2.5 \pm 1.8$ & $1.5 \pm 2.0$ & $0.8 \pm 2.7$ \\
\hline $9 / 8$ & $1.5 \pm 1.4$ & NS & $1.5 \pm 5.6$ & $2.8 \pm 1.6$ & NS & $0.5 \pm 1.9$ & $3.3 \pm 1.9$ & $0.9 \pm 1.8$ & $-1.0 \pm 1.9$ \\
\hline $9 / 15$ & $1.2 \pm 1.3$ & $-0.6 \pm 1.2$ & $-0.2 \pm 3.8$ & $2.0 \pm 1.4$ & NS & $1.3 \pm 2.3$ & $1.4 \pm 1.4$ & $2.6 \pm 2.2$ & $1.3 \pm 2.9$ \\
\hline $9 / 22$ & $2.0 \pm 1.5$ & $2.0 \pm 2.0$ & NS & $1.2 \pm 1.1$ & $1.7 \pm 1.6$ & $0.1 \pm 1.9$ & $3.9 \pm 2.0$ & $2.5 \pm 2.2$ & $2.1 \pm 3.2$ \\
\hline $9 / 29$ & $2.1 \pm 1.4$ & $1.1 \pm 1.6$ & $2.5 \pm 3.0$ & $2.2 \pm 1.4$ & $1.2 \pm 1.2$ & $1.8 \pm 2.3$ & $2.3 \pm 1.5$ & $1.0 \pm 1.6$ & $1.0 \pm 2.9$ \\
\hline $10 / 6$ & $0.6 \pm 1.0$ & $0.2 \pm 1.4$ & $0.7 \pm 2.5$ & $1.3 \pm 1.2$ & $0.5 \pm 1.2$ & $1.1 \pm 2.1$ & $0.4 \pm 1.0$ & $0.8 \pm 1.8$ & $1.3 \pm 2.9$ \\
\hline $10 / 13$ & $1.3 \pm 1.6$ & $0.6 \pm 1.8$ & $-0.5 \pm 5.8$ & $0.4 \pm 1.2$ & $0.0 \pm 1.4$ & $-0.5 \pm 1.5$ & $0.1 \pm 1.4$ & $0.2 \pm 2.0$ & $-1.0 \pm 3.8$ \\
\hline $10 / 20$ & $0.4 \pm 1.2$ & $0.3 \pm 1.8$ & $1.5 \pm 2.8$ & $0.8 \pm 1.3$ & $1.0 \pm 1.6$ & $0.1 \pm 1.7$ & $2.1 \pm 1.8$ & $1.7 \pm 2.4$ & $3.4 \pm 3.5$ \\
\hline $10 / 27$ & $0.8 \pm 1.1$ & $0.4 \pm 1.8$ & $2.2 \pm 2.8$ & $3.1 \pm 1.7$ & $0.4 \pm 1.4$ & $0.5 \pm 2.3$ & $2.0 \pm 1.5$ & $1.4 \pm 2.4$ & $2.9 \pm 4.3$ \\
\hline $11 / 3$ & $2.2 \pm 1.4$ & $0.1 \pm 1.8$ & $1.0 \pm 2.5$ & $0.8 \pm 0.9$ & $0.6 \pm 1.4$ & $0.9 \pm 2.3$ & $2.2 \pm 1.4$ & $0.9 \pm 2.0$ & $1.6 \pm 3.2$ \\
\hline $11 / 10$ & $3.1 \pm 1.6$ & $0.6 \pm 1.6$ & $2.0 \pm 3.0$ & $1.1 \pm 0.9$ & $1.5 \pm 1.4$ & $0.9 \pm 2.1$ & $2.1 \pm 1.4$ & $2.5 \pm 2.0$ & $-0.2 \pm 2.4$ \\
\hline $11 / 17$ & $1.1 \pm 1.0$ & $0.6 \pm 1.6$ & $2.2 \pm 3.0$ & $1.8 \pm 1.1$ & $-0.8 \pm 1.0$ & $-0.5 \pm 1.5$ & $1.0 \pm 0.9$ & $0.4 \pm 2.0$ & $-0.8 \pm 2.4$ \\
\hline $11 / 24$ & $0.4 \pm 1.4$ & $0.2 \pm 1.6$ & $-0.2 \pm 2.5$ & $1.4 \pm 1.6$ & $0.8 \pm 1.4$ & $-0.1 \pm 2.1$ & $2.6 \pm 2.0$ & $-0.3 \pm 1.8$ & $2.6 \pm 3.8$ \\
\hline $12 / 1$ & $2.0 \pm 1.7$ & $0.5 \pm 1.4$ & $-0.7 \pm 1.5$ & $1.4 \pm 1.8$ & $0.0 \pm 1.0$ & $0.3 \pm 1.5$ & $1.8 \pm 1.8$ & $1.5 \pm 1.8$ & $0.0 \pm 1.9$ \\
\hline $12 / 8$ & $0.8 \pm 1.2$ & $0.2 \pm 1.6$ & $1.5 \pm 2.3$ & $0.2 \pm 0.9$ & $-0.2 \pm 1.2$ & $0.1 \pm 1.7$ & $2.8 \pm 1.1$ & $-0.7 \pm 1.8$ & $0.0 \pm 2.1$ \\
\hline $12 / 15$ & $0.0 \pm 0.9$ & $-0.8 \pm 1.4$ & $1.0 \pm 2.3$ & $0.7 \pm 0.9$ & $-0.3 \pm 1.2$ & $0.9 \pm 1.9$ & $1.8 \pm 1.2$ & $0.0 \pm 1.8$ & $0.2 \pm 2.4$ \\
\hline $12 / 21$ & $0.0 \pm 0.8$ & $1.3 \pm 1.8$ & $-0.7 \pm 1.8$ & $0.1 \pm 0.8$ & NS & $-0.1 \pm 1.5$ & $0.1 \pm 0.8$ & $0.0 \pm 1.8$ & $1.8 \pm 2.7$ \\
\hline $12 / 28$ & $1.5 \pm 1.2$ & $0.8 \pm 1.6$ & $1.2 \pm 2.3$ & $1.9 \pm 1.2$ & $2.0 \pm 1.6$ & $2.2 \pm 2.3$ & $2.1 \pm 1.3$ & $0.6 \pm 1.8$ & $2.1 \pm 2.9$ \\
\hline
\end{tabular}


1995 INEL Annual Site Environmental Report

\begin{tabular}{|c|c|c|c|c|c|c|c|c|c|}
\hline \multirow{3}{*}{$\begin{array}{l}\text { Week } \\
\text { Ending }\end{array}$} & \multicolumn{9}{|c|}{ Gross Beta $\left(10^{15} \mu \mathrm{Ci} / \mathrm{mL}\right)^{2}$} \\
\hline & \multicolumn{3}{|c|}{ Craters of the Moon } & \multicolumn{3}{|c|}{ EFS } & \multicolumn{3}{|c|}{ Van Buren } \\
\hline & $\mathbf{F}$ & $L$ & $\mathbf{S}$ & $F$ & $L$ & $\mathbf{S}$ & $F$ & $L$ & $\mathrm{~s}$ \\
\hline $1 / 6$ & $46 \pm 6$ & $24 \pm 4$ & $53 \pm 18$ & $39 \pm 6$ & $21 \pm 3$ & $36 \pm 8$ & $39 \pm 6$ & $23 \pm 4$ & $51 \pm 19$ \\
\hline $1 / 13$ & $31 \pm 6$ & $17 \pm 3$ & $58 \pm 10$ & $46 \pm 6$ & $25 \pm 3$ & $17 \pm 6$ & $46 \pm 7$ & $17 \pm 4$ & $54 \pm 13$ \\
\hline $1 / 20$ & $16 \pm 4$ & $12 \pm 3$ & $23 \pm 8$ & $16 \pm 3$ & $12 \pm 3$ & $17 \pm 6$ & $12 \pm 4$ & $14 \pm 4$ & $35 \pm 11$ \\
\hline $1 / 27$ & $36 \pm 5$ & $26 \pm 4$ & $-5 \pm 3$ & $39 \pm 6$ & $29 \pm 3$ & $43 \pm 9$ & $26 \pm 7$ & $14 \pm 3$ & $59 \pm 13$ \\
\hline $2 / 3$ & $25 \pm 5$ & $16 \pm 3$ & $20 \pm 8$ & $27 \pm 5$ & $18 \pm 3$ & $21 \pm 8$ & $29 \pm 5$ & $21 \pm 4$ & $29 \pm 11$ \\
\hline $2 / 10$ & $30 \pm 5$ & $29 \pm 4$ & $40 \pm 10$ & $33 \pm 5$ & $33 \pm 4$ & $23 \pm 8$ & $35 \pm 6$ & $27 \pm 4$ & $40 \pm 11$ \\
\hline $2 / 17$ & $35 \pm 5$ & $25 \pm 4$ & $30 \pm 8$ & $34 \pm 5$ & $26 \pm 3$ & $21 \pm 8$ & $34 \pm 5$ & $26 \pm 4$ & $32 \pm 11$ \\
\hline $2 / 24$ & $19 \pm 4$ & $13 \pm 4$ & $33 \pm 10$ & $29 \pm 5$ & $21 \pm 4$ & $24 \pm 8$ & $27 \pm 5$ & $20 \pm 4$ & $32 \pm 11$ \\
\hline $3 / 3$ & $46 \pm 6$ & $32 \pm 4$ & $68 \pm 13$ & $46 \pm 6$ & $40 \pm 4$ & $41 \pm 9$ & $49 \pm 7$ & $36 \pm 4$ & $67 \pm 13$ \\
\hline $3 / 10$ & $25 \pm 5$ & $20 \pm 4$ & $35 \pm 10$ & $31 \pm 5$ & $26 \pm 4$ & $32 \pm 8$ & $30 \pm 5$ & $22 \pm 4$ & $32 \pm 11$ \\
\hline $3 / 17$ & $16 \pm 4$ & $9 \pm 3$ & $17 \pm 8$ & $16 \pm 4$ & $10 \pm 3$ & $13 \pm 6$ & $16 \pm 4$ & $13 \pm 4$ & $24 \pm 11$ \\
\hline $3 / 24$ & $15 \pm 5$ & $10 \pm 3$ & $10 \pm 8$ & $17 \pm 4$ & $17 \pm 3$ & $9 \pm 6$ & $17 \pm 4$ & $14 \pm 4$ & $27 \pm 11$ \\
\hline $3 / 31$ & $22 \pm 4$ & $10 \pm 3$ & $18 \pm 8$ & $17 \pm 4$ & $11 \pm 3$ & $15 \pm 6$ & $17 \pm 4$ & $13 \pm 4$ & $21 \pm 8$ \\
\hline $4 / 7$ & $23 \pm 5$ & $18 \pm 4$ & $30 \pm 10$ & $21 \pm 4$ & $20 \pm 4$ & $28 \pm 8$ & $23 \pm 6$ & $17 \pm 4$ & $38 \pm 11$ \\
\hline $4 / 14$ & $\mathrm{NS}^{\mathrm{b}}$ & $5 \pm 3$ & $23 \pm 13$ & $15 \pm 4$ & $7 \pm 3$ & $11 \pm 6$ & $16 \pm 4$ & $12 \pm 6$ & $16 \pm 8$ \\
\hline $4 / 21$ & $25 \pm 5$ & $18 \pm 4$ & $28 \pm 10$ & $21 \pm 4$ & $20 \pm 3$ & $13 \pm 6$ & $21 \pm 5$ & $21 \pm 4$ & $29 \pm 11$ \\
\hline $4 / 28$ & $24 \pm 5$ & $17 \pm 3$ & $28 \pm 10$ & $19 \pm 4$ & $16 \pm 3$ & $24 \pm 8$ & $45 \pm 7$ & $17 \pm 4$ & $38 \pm 11$ \\
\hline $5 / 5$ & $18 \pm 3$ & $9 \pm 3$ & $10 \pm 8$ & $10 \pm 4$ & $14 \pm 3$ & $11 \pm 6$ & $12 \pm 4$ & $10 \pm 3$ & $0 \pm 5$ \\
\hline $5 / 12$ & $21 \pm 4$ & $14 \pm 3$ & $-3 \pm 5$ & $18 \pm 4$ & $10 \pm 3$ & $15 \pm 6$ & $18 \pm 5$ & $12 \pm 4$ & $5 \pm 8$ \\
\hline $5 / 19$ & $13 \pm 4$ & $9 \pm 3$ & $15 \pm 8$ & $17 \pm 4$ & $5 \pm 2$ & $8 \pm 6$ & $18 \pm 5$ & $10 \pm 3$ & $8 \pm 8$ \\
\hline $5 / 26$ & $32 \pm 5$ & $23 \pm 4$ & $25 \pm 8$ & $26 \pm 5$ & $23 \pm 4$ & $17 \pm 6$ & $28 \pm 4$ & $20 \pm 4$ & $27 \pm 8$ \\
\hline $6 / 2$ & $26 \pm 5$ & $19 \pm 3$ & $23 \pm 10$ & $23 \pm 4$ & $17 \pm 3$ & $11 \pm 6$ & $21 \pm 4$ & $20 \pm 4$ & $16 \pm 8$ \\
\hline $6 / 9$ & $16 \pm 4$ & $12 \pm 3$ & $13 \pm 8$ & $17 \pm 4$ & $18 \pm 3$ & $9 \pm 6$ & $17 \pm 4$ & $15 \pm 4$ & $13 \pm 11$ \\
\hline $6 / 16$ & $20 \pm 4$ & $13 \pm 3$ & $23 \pm 8$ & $22 \pm 4$ & $14 \pm 3$ & $11 \pm 6$ & $18 \pm 4$ & $12 \pm 4$ & $19 \pm 8$ \\
\hline $6 / 23$ & $21 \pm 4$ & $14 \pm 3$ & NS & $20 \pm 4$ & $12 \pm 3$ & $11 \pm 6$ & $21 \pm 4$ & $18 \pm 4$ & $11 \pm 8$ \\
\hline $6 / 30$ & $19 \pm 4$ & $18 \pm 3$ & $25 \pm 10$ & $18 \pm 4$ & $17 \pm 3$ & $15 \pm 6$ & $27 \pm 5$ & $19 \pm 4$ & NS \\
\hline $7 / 7$ & $20 \pm 6$ & $17 \pm 4$ & $56 \pm 13$ & $24 \pm 5$ & $15 \pm 3$ & $28 \pm 8$ & $21 \pm 5$ & $18 \pm 4$ & $54 \pm 11$ \\
\hline $7 / 14$ & $28 \pm 5$ & $24 \pm 4$ & $\mathrm{NS}$ & $29 \pm 5$ & $17 \pm 3$ & $13 \pm 6$ & $30 \pm 6$ & $26 \pm 4$ & $19 \pm 8$ \\
\hline $7 / 21$ & $29 \pm 5$ & $24 \pm 4$ & $33 \pm 10$ & $27 \pm 4$ & $20 \pm 3$ & $23 \pm 6$ & $28 \pm 5$ & $22 \pm 4$ & $38 \pm 11$ \\
\hline $7 / 28$ & $31 \pm 5$ & $24 \pm 4$ & $46 \pm 25$ & $34 \pm 5$ & NS & $17 \pm 6$ & $37 \pm 6$ & $33 \pm 4$ & $24 \pm 11$ \\
\hline $8 / 4$ & $29 \pm 5$ & $18 \pm 4$ & $28 \pm 15$ & $29 \pm 5$ & $21 \pm 3$ & $15 \pm 6$ & $28 \pm 6$ & $23 \pm 4$ & $38 \pm 11$ \\
\hline $8 / 11$ & $34 \pm 5$ & $17 \pm 3$ & $23 \pm 8$ & $27 \pm 4$ & $23 \pm 4$ & $21 \pm 6$ & $28 \pm 5$ & $26 \pm 4$ & $24 \pm 8$ \\
\hline $8 / 18$ & $26 \pm 5$ & $22 \pm 3$ & $18 \pm 8$ & $29 \pm 5$ & $20 \pm 3$ & $23 \pm 6$ & $33 \pm 6$ & $24 \pm 4$ & $32 \pm 8$ \\
\hline $8 / 25$ & $29 \pm 5$ & $16 \pm 3$ & $5 \pm 10$ & $27 \pm 5$ & $29 \pm 4$ & $13 \pm 6$ & $31 \pm 7$ & $23 \pm 4$ & $\mathrm{NS}$ \\
\hline $9 / 1$ & $36 \pm 6$ & $28 \pm 4$ & $38 \pm 10$ & $66 \pm 7$ & $20 \pm 3$ & $23 \pm 8$ & $73 \pm 9$ & $28 \pm 4$ & $35 \pm 11$ \\
\hline $9 / 8$ & $34 \pm 6$ & NS & $38 \pm 15$ & $28 \pm 5$ & NS & $17 \pm 6$ & $29 \pm 6$ & $28 \pm 4$ & $27 \pm 8$ \\
\hline $9 / 15$ & $34 \pm 6$ & $21 \pm 4$ & $20 \pm 13$ & $32 \pm 6$ & NS & $19 \pm 6$ & $31 \pm 6$ & $24 \pm 4$ & $32 \pm 8$ \\
\hline $9 / 22$ & $41 \pm 7$ & $30 \pm 4$ & NS & $42 \pm 6$ & $24 \pm 3$ & $23 \pm 6$ & $40 \pm 7$ & $35 \pm 4$ & $38 \pm 11$ \\
\hline $9 / 29$ & $31 \pm 5$ & $32 \pm 4$ & $30 \pm 10$ & $35 \pm 6$ & $29 \pm 4$ & $28 \pm 8$ & $34 \pm 6$ & $29 \pm 4$ & $32 \pm 8$ \\
\hline $10 / 6$ & $15 \pm 4$ & $16 \pm 3$ & $15 \pm 7$ & $21 \pm 4$ & $17 \pm 3$ & $11 \pm 5$ & $22 \pm 4$ & $19 \pm 4$ & $18 \pm 8$ \\
\hline $10 / 13$ & $22 \pm 4$ & $16 \pm 4$ & $34 \pm 18$ & $22 \pm 4$ & $18 \pm 3$ & $16 \pm 6$ & $18 \pm 4$ & $22 \pm 4$ & $54 \pm 16$ \\
\hline $10 / 20$ & $26 \pm 5$ & $19 \pm 4$ & $22 \pm 8$ & $27 \pm 5$ & $27 \pm 4$ & $16 \pm 6$ & $24 \pm 5$ & $19 \pm 4$ & $26 \pm 9$ \\
\hline $10 / 27$ & $18 \pm 4$ & $13 \pm 3$ & $15 \pm 7$ & $21 \pm 5$ & $16 \pm 3$ & $16 \pm 7$ & $20 \pm 5$ & $19 \pm 4$ & $22 \pm 11$ \\
\hline $11 / 3$ & $23 \pm 4$ & $19 \pm 4$ & $24 \pm 8$ & $37 \pm 5$ & $27 \pm 4$ & $22 \pm 7$ & $29 \pm 5$ & $25 \pm 4$ & $27 \pm 9$ \\
\hline $11 / 10$ & $33 \pm 5$ & $23 \pm 4$ & $33 \pm 9$ & $35 \pm 5$ & $28 \pm 3$ & $21 \pm 7$ & $27 \pm 5$ & $23 \pm 4$ & $37 \pm 10$ \\
\hline $11 / 17$ & $17 \pm 4$ & $8 \pm 3$ & $12 \pm 7$ & $19 \pm 4$ & $8 \pm 2$ & $12 \pm 6$ & $22 \pm 4$ & $12 \pm 4$ & $13 \pm 8$ \\
\hline $11 / 24$ & $32 \pm 11$ & $22 \pm 3$ & $31 \pm 10$ & $40 \pm 10$ & $34 \pm 4$ & $34 \pm 8$ & $30 \pm 11$ & $23 \pm 4$ & $36 \pm 11$ \\
\hline $12 / 1$ & $41 \pm 11$ & $9 \pm 3$ & $24 \pm 12$ & $31 \pm 11$ & $8 \pm 2$ & $15 \pm 10$ & $28 \pm 11$ & $17 \pm 4$ & $26 \pm 14$ \\
\hline $12 / 8$ & $17 \pm 5$ & $13 \pm 3$ & $17 \pm 14$ & $10 \pm 4$ & $11 \pm 3$ & $5 \pm 12$ & $16 \pm 5$ & $17 \pm 4$ & $10 \pm 15$ \\
\hline $12 / 15$ & $19 \pm 6$ & $15 \pm 3$ & $17 \pm 14$ & $26 \pm 5$ & $21 \pm 3$ & $20 \pm 11$ & $24 \pm 5$ & $14 \pm 4$ & $25 \pm 16$ \\
\hline $12 / 22$ & $21 \pm 5$ & $20 \pm 4$ & $23 \pm 14$ & $19 \pm 5$ & $\overline{N S}$ & $22 \pm 12$ & $21 \pm 5$ & $15 \pm 4$ & $38 \pm 17$ \\
\hline $12 / 29$ & $36 \pm 6$ & $37 \pm 4$ & $46 \pm 15$ & $57 \pm 6$ & $61 \pm 4$ & $37 \pm 12$ & $44 \pm 6$ & $53 \pm 6$ & $62 \pm 17$ \\
\hline
\end{tabular}




\begin{tabular}{|c|c|c|c|c|c|c|c|}
\hline \multicolumn{8}{|c|}{$\begin{array}{l}\text { TABLE } 7.8 \\
\text { COMPARISON OF FOUNDATION AND STATE OF IDAHO WATER MONITORING RESULTS } \\
(1995)\end{array}$} \\
\hline \multirow[b]{2}{*}{ Location } & \multirow[b]{2}{*}{ Date } & \multicolumn{2}{|c|}{$\begin{array}{c}\text { Gross Alpha } \\
\left(10^{-9} \mu \mathrm{Ci} / \mathrm{mL}\right)^{\mathrm{a}}\end{array}$} & \multicolumn{2}{|c|}{$\begin{array}{c}\text { Gross Beta } \\
\left(10^{-9} \mu \mathrm{Ci} / \mathrm{mL}\right)^{\mathrm{a}}\end{array}$} & \multicolumn{2}{|c|}{$\begin{array}{c}\text { Tritium } \\
\left(10^{-9} \mu \mathrm{Ci} / \mathrm{mL}\right)^{\mathrm{a}}\end{array}$} \\
\hline & & Foundation & State & Foundation & State & Foundation & State \\
\hline \multirow{4}{*}{$\begin{array}{c}\text { Minidoka } \\
\text { (Drinking } \\
\text { Water) }\end{array}$} & $02 / 95$ & $2 \pm 3$ & $0 \pm 2$ & $1 \pm 2$ & $2 \pm 2$ & $200 \pm 170$ & $0 \pm 170$ \\
\hline & $05 / 95$ & $1 \pm 3$ & $1 \pm 2$ & $1 \pm 2$ & $2 \pm 2$ & $240 \pm 160$ & $100 \pm 160$ \\
\hline & $08 / 95$ & $1 \pm 3$ & $-5 \pm 4$ & $3 \pm 2$ & $3 \pm 2$ & $0 \pm 160$ & $-20 \pm 120$ \\
\hline & $11 / 95$ & $-3 \pm 4$ & $1 \pm 5$ & $3 \pm 2$ & $5 \pm 2$ & $30 \pm 90$ & $0 \pm 90$ \\
\hline \multirow{4}{*}{$\begin{array}{c}\text { Shoshone } \\
\text { (Drinking } \\
\text { Water) }\end{array}$} & $02 / 95$ & $2 \pm 3$ & $3 \pm 3$ & $2 \pm 2$ & $1 \pm 2$ & $80 \pm 170$ & $120 \pm 170$ \\
\hline & $05 / 95$ & $1 \pm 2$ & $1 \pm 2$ & $1 \pm 1$ & $5 \pm 2$ & $370 \pm 160$ & $100 \pm 160$ \\
\hline & $08 / 95$ & $3 \pm 4$ & $1 \pm 5$ & $3 \pm 2$ & $1 \pm 2$ & $0 \pm 160$ & $110 \pm 120$ \\
\hline & $11 / 95$ & $\frac{17}{4 \pm 5}$ & $5 \pm 6$ & $3 \pm 2$ & $3 \pm 2$ & $-80 \pm 110$ & $0 \pm 90$ \\
\hline \multirow{4}{*}{$\begin{array}{c}\text { Bill Jones } \\
\text { Hatchery } \\
\text { (Surface } \\
\text { Water) }\end{array}$} & $02 / 95$ & $\frac{4}{1 \pm 2}$ & $2 \pm 2$ & $5 \pm 2$ & $1 \pm 1$ & $-100 \pm 170$ & $30 \pm 160$ \\
\hline & $05 / 95$ & $\frac{1 \pm 2}{0 \pm 2}$ & $\frac{1 \pm 2}{1 \pm 2}$ & $3 \pm 2$ & $5 \pm 2$ & $250 \pm 160$ & $0 \pm 160$ \\
\hline & $08 / 95$ & $\frac{0 \pm 2}{4 \pm 3}$ & $1 \pm 2$ & $2 \pm 2$ & $2 \pm 2$ & $0 \pm 160$ & $20 \pm 120$ \\
\hline & $11 / 95$ & $0 \pm 4$ & $-1 \pm 4$ & $3 \pm 2$ & $4 \pm 2$ & $0 \pm 90$ & $0 \pm 90$ \\
\hline \multirow{4}{*}{$\begin{array}{c}\text { Clear } \\
\text { Springs } \\
\text { (Surface } \\
\text { Water) }\end{array}$} & $\frac{11 / 7 J}{02 / 95}$ & $\frac{1 \pm 4}{1 \pm 2}$ & $\frac{1 \pm}{3 \pm 3}$ & $4 \pm 2$ & $\frac{1+2}{4 \pm 2}$ & $-360 \pm 160$ & $10 \pm 160$ \\
\hline & $05 / 95$ & $\frac{1 \pm 2}{4 \pm 5}$ & $0 \pm 1$ & $12 \pm 2$ & $2 \pm 1$ & $-160 \pm 160$ & $100 \pm 160$ \\
\hline & $08 / 95$ & $\frac{4 \pm J}{4 \pm 4}$ & $-1 \pm 5$ & $2 \pm 2$ & $3 \pm 2$ & $0 \pm 160$ & $-20 \pm 120$ \\
\hline & $\frac{00 / 95}{11 / 95}$ & $\frac{4 I+4}{1 \pm 5}$ & $-2 \pm 5$ & $6 \pm 2$ & $-1 \pm 2$ & $10 \pm 90$ & $-100 \pm 90$ \\
\hline \multirow{4}{*}{$\begin{array}{l}\text { Alpheus } \\
\text { Spring } \\
\text { (Surface } \\
\text { Water) }\end{array}$} & $02 / 95$ & $\frac{1 \pm 3}{2 \pm 3}$ & $\frac{1}{1 \pm 3}$ & $3 \pm 2$ & $5 \pm 2$ & $60 \pm 170$ & $120 \pm 170$ \\
\hline & $05 / 95$ & $0+3$ & $2 \pm 3$ & $7 \pm 2$ & $8 \pm 2$ & $270 \pm 160$ & $200 \pm 160$ \\
\hline & $08 / 95$ & $2+4$ & $-2 \pm 5$ & $6 \pm 2$ & $10 \pm 2$ & $-10 \pm 160$ & $70 \pm 120$ \\
\hline & $11 / 95$ & $1 \pm 4$ & $4 \pm 7$ & $2 \pm 2$ & $7 \pm 2$ & $100 \pm 90$ & $100 \pm 90$ \\
\hline
\end{tabular}




\section{APPENDIX A ENVIRONMENTAL STANDARDS AND REGULATIONS}

The following environmental standards and regulations are applicable, in whole or in part, on the INEL or at the INEL boundary.

U.S. Environmental Protection Agency, "National Primary and Secondary Ambient Air Quality Standards," 40 CFR 50, 1995.

U.S. Environmental Protection Agency, "National Emission Standards for Hazardous Air Pollutants," 40 CFR 61, 1995.

U.S. Environmental Protection Agency, "National Interim Primary Drinking Water Regulations," 40 CFR 141, 1995.

\section{U.S. Environmental Protection Agency, "Hazardous Waste Management System: General," 40 CFR 260, 1995.}

U.S. Environmental Protection Agency, "Identifying and Listing of Hazardous Wastes," 40 CFR 261, 1995.

U.S. Environmental Protection Agency, "Standards Applicable to Generators of Hazardous Waste," 40 CFR 262, 1995.

U.S. Environmental Protection Agency, "Standards Applicable to Transporters of Hazardous Waste," 40 CFR 263, 1995.

U.S. Environmental Protection Agency, "Standards for Owners and Operators of Hazardous Waste Treatment, Storage and Disposal Facilities," 40 CFR 264, 1995.

U.S. Environmental Protection Agency, "Interim Status Standards for Owners and Operators of Hazardous Waste Treatment,
Storage and Disposal Facilities," 40 CFR 265, 1995.

U.S. Environmental Protection Agency, "Interim Standards for Owners and Operators of New Hazardous Waste Land Disposal Facilities," 40 CFR 267, 1995.

Department of Health and Welfare, State of Idaho, "Rules and Regulations for the Control of Air Pollution in Idaho," 1972, as amended through May 1990.

Department of Health and Welfare, State of Idaho, "Idaho Regulations for Public Drinking Water Systems," 16.01.8000-16.01.8999, October 1993.

The Derived Concentration Guides (DCGs) are based on the DOE standard ${ }^{\mathrm{a}}$ and have been calculated using DOE models and parameters for internal ${ }^{b}$ and external ${ }^{c}$ exposure. These are shown in Table I. The most restrictive guide is listed when there is a difference between the soluble and insoluble chemical forms. The DCGs consider only the inhalation of air, the ingestion of water, or submersion in air. The principal standards and guides for release of radionuclides at the INEL are those of DOE Order 5400.5, entitled "Radiation Protection of the Public and the Environment." The DOE standard is shown in Table II along with the EPA standard for protection of the public, airborne pathway only.

\footnotetext{
- U.S. Department of Energy Order 5400.5, "Radiation Protection of the Public and the Environment", January 7, 1993.

b U.S. Department of Energy, Internal Dose Conversion Factors for Calculation of Dose to the Public, DOE/EH-0071, July 1988.

U.S. Department of Energy, External Dose Conversion Factors for
} Calculation of Dose to the Public, DOE/EH-0070, July 7988. 
Ambient air quality standards are shown in Table III. Water quality standards are dependent on the type of drinking water system sampled. Table IV is a partial list of maximum contaminant levels set by the EPA for public community drinking water systems in $40 \mathrm{CFR}$ 141.

\section{TABLE I}

\section{DERIVED CONCENTRATION GUIDES FOR RADIATION PROTECTION}

\begin{tabular}{|c|c|c|c|c|c|}
\hline \multicolumn{3}{|c|}{$\begin{array}{l}\text { Derived Concentration Guide }{ }^{a} \\
(\mu \mathrm{Ci} / \mathrm{mL})\end{array}$} & \multicolumn{3}{|c|}{$\begin{array}{l}\text { Derived Concentration Guide } \\
(\mu \mathrm{Ci} / \mathrm{mL})\end{array}$} \\
\hline Radionuclide & In Air & In Water & Radionuclide & In Air & In Water \\
\hline Gross Alpha ${ }^{\mathrm{b}}$ & $2 \times 10^{-14}$ & $3 \times 10^{-8}$ & ${ }^{129} \mathrm{I}$ & $7 \times 10^{-11}$ & $5 \times 10^{-7}$ \\
\hline Gross Beta $^{c}$ & $3 \times 10^{-12}$ & $1 \times 10^{-7}$ & ${ }^{131} \mathrm{I}$ & $4 \times 10^{-10}$ & $3 \times 10^{-6}$ \\
\hline${ }^{3} \mathrm{H}$ & $1 \times 10^{-7}$ & $2 \times 10^{-3}$ & ${ }^{132} \mathrm{I}$ & $4 \times 10^{-8}$ & $2 \times 10^{-4}$ \\
\hline${ }^{14} \mathrm{C}$ & $5 \times 10^{-7}$ & $7 \times 10^{-5}$ & ${ }^{133} \mathrm{I}$ & $2 \times 10^{-9}$ & $1 \times 10^{-5}$ \\
\hline${ }^{24} \mathrm{Na}^{\mathrm{d}}$ & $4 \times 10^{-9}$ & $1 \times 10^{-4}$ & ${ }^{135} \mathrm{I}$ & $1 \times 10^{-8}$ & $7 \times 10^{-5}$ \\
\hline${ }^{41} \mathrm{Ar}$ & $1 \times 10-^{8}$ & - & ${ }^{131 \mathrm{~m}} \mathrm{Xe}$ & $2 \times 10^{-6}$ & - \\
\hline${ }^{51} \mathrm{Cr}$ & $5 \times 10^{-8}$ & $1 \times 10^{-3}$ & ${ }^{133} \mathrm{Xe}$ & $5 \times 10^{-7}$ & - \\
\hline ${ }^{54} \mathrm{Mn}$ & $2 \times 10^{-9}$ & $5 \times 10^{-5}$ & ${ }^{133 m} \mathrm{Xe}$ & $6 \times 10^{-7}$ & - \\
\hline 年8 $\mathrm{Co}$ & $2 \times 10^{-9}$ & $4 \times 10^{-5}$ & ${ }^{135} \mathrm{Xe}$ & $8 \times 10^{-8}$ & - \\
\hline${ }^{60} \mathrm{Co}$ & $8 \times 10^{-11}$ & $5 \times 10^{-6}$ & ${ }^{135 \mathrm{~m}} \mathrm{Xe}$ & $5 \times 10^{-8}$ & - \\
\hline${ }^{{ }^{5} \mathrm{Zn}}$ & $6 \times 10^{-10}$ & $9 \times 10^{-6}$ & ${ }^{138} \mathrm{Xe}$ & $2 \times 10^{-8}$ & - \\
\hline${ }^{85} \mathrm{Kr}$ & $3 \times 10^{-6}$ & - & ${ }^{134} \mathrm{Cs}$ & $2 \times 10^{-10}$ & $2 \times 10^{-6}$ \\
\hline${ }^{85 \mathrm{~m}} \mathrm{Kr}$ & $1 \times 10^{-7}$ & - & ${ }^{137} \mathrm{Cs}$ & $4 \times 10^{-10}$ & $3 \times 10^{-6}$ \\
\hline${ }^{87} \mathrm{Kr}$ & $2 \times 10^{-8}$ & - & ${ }^{138} \mathrm{Cs}$ & $1 \times 10^{-7}$ & $9 \times 10^{-4}$ \\
\hline${ }^{88} \mathrm{Kr}$ & $9 \times 10^{-9}$ & - & ${ }^{139} \mathrm{Ba}$ & $7 \times 10^{-8}$ & $3 \times 10^{-4}$ \\
\hline${ }^{88} \mathrm{~d} \mathrm{Rb}$ & $3 \times 10^{-8}$ & $8 \times 10^{-4}$ & ${ }^{140} \mathrm{Ba}$ & $3 \times 10^{-9}$ & $2 \times 10^{-5}$ \\
\hline${ }^{89} \mathrm{Rb}$ & $3 \times 10^{-7}$ & $2 \times 10^{-3}$ & ${ }^{141} \mathrm{Ce}$ & $1 \times 10^{-9}$ & $5 \times 10^{-5}$ \\
\hline${ }^{89} \mathrm{Sr}$ & $3 \times 10^{-10}$ & $2 \times 10^{-5}$ & ${ }^{144} \mathrm{Ce}$ & $3 \times 10^{-11}$ & $7 \times 10^{-6}$ \\
\hline${ }^{90} \mathrm{Sr}$ & $9 \times 10^{-12}$ & $1 \times 10^{-6}$ & ${ }^{238} \mathrm{Pu}$ & $3 \times 10^{-14}$ & $4 \times 10^{-8}$ \\
\hline${ }^{91 \mathrm{~m}} \mathrm{Y}$ & $4 \times 10^{-7}$ & $4 \times 10^{-3}$ & ${ }^{239} \mathrm{Pu}$ & $2 \times 10^{-14}$ & $3 \times 10^{-8}$ \\
\hline${ }^{95} \mathrm{Zr}$ & $6 \times 10^{-10}$ & $4 \times 10^{-5}$ & ${ }^{240} \mathrm{Pu}$ & $2 \times 10^{-14}$ & $3 \times 10^{-8}$ \\
\hline${ }^{99} \mathrm{~m} \mathrm{Tc}$ & $4 \times 10^{-7}$ & $2 \times 10^{-3}$ & ${ }^{241} \mathrm{Am}$ & $2 \times 10^{-14}$ & $3 \times 10^{-8}$ \\
\hline${ }^{103} \mathrm{Ru}$ & $2 \times 10^{-9}$ & $5 \times 10^{-5}$ & & & \\
\hline${ }^{106} \mathrm{Ru}$ & $3 \times 10^{-11}$ & $6 \times 10^{-6}$ & & & \\
\hline${ }^{125} \mathrm{Sb}$ & $1 \times 10^{-9}$ & $5 \times 10^{-5}$ & & & \\
\hline $\begin{array}{l}\text { Derived concer } \\
\text { equivalent of } 1 \\
\text { Based on }{ }^{241} \mathrm{Am} \\
\text { Based on the } \mathrm{m} \\
\text { Submersion in }\end{array}$ & $\begin{array}{l}\text { ation guides } \\
\text { rem/yr. } \\
\text { un, and } \\
\text { strictive be } \\
\text { al of gas is }\end{array}$ & $\begin{array}{l}\text { s) are from } 1 \\
\text { ter }\left({ }^{228} \mathrm{Ra}\right) \text {. } \\
\text { estrictive tha }\end{array}$ & halation pathy & & \\
\hline
\end{tabular}




\begin{tabular}{|c|c|c|}
\hline \multicolumn{3}{|c|}{$\begin{array}{l}\text { TABLE II } \\
\text { RADIATION STANDARDS FOR PROTECTION OF THE PUBLIC IN THE } \\
\text { VICINITY OF DOE FACILITIES }\end{array}$} \\
\hline \multirow[b]{3}{*}{$\begin{array}{l}\text { DOE Standard for routine DOE activities } \\
\text { (all pathways) }\end{array}$} & \multicolumn{2}{|c|}{ Effective Dose Equivalent } \\
\hline & mrem/yr & $\underline{\mathbf{m S v} / \mathbf{v r}}$ \\
\hline & 100 & 1 \\
\hline $\begin{array}{l}\text { EPA Standard for site operations } \\
\text { (airborne pathway only) }\end{array}$ & 10 & 0.1 \\
\hline \multicolumn{3}{|c|}{$\begin{array}{l}\text { The effective dose equivalent for any member of the public from all routine DOE operations including } \\
\text { remedial activities and release of naturally-occurring radionuclides shall not exceed this value. Routin } \\
\text { operations refers to normal, planned operations and does not include accidental or unplanned releases. }\end{array}$} \\
\hline
\end{tabular}

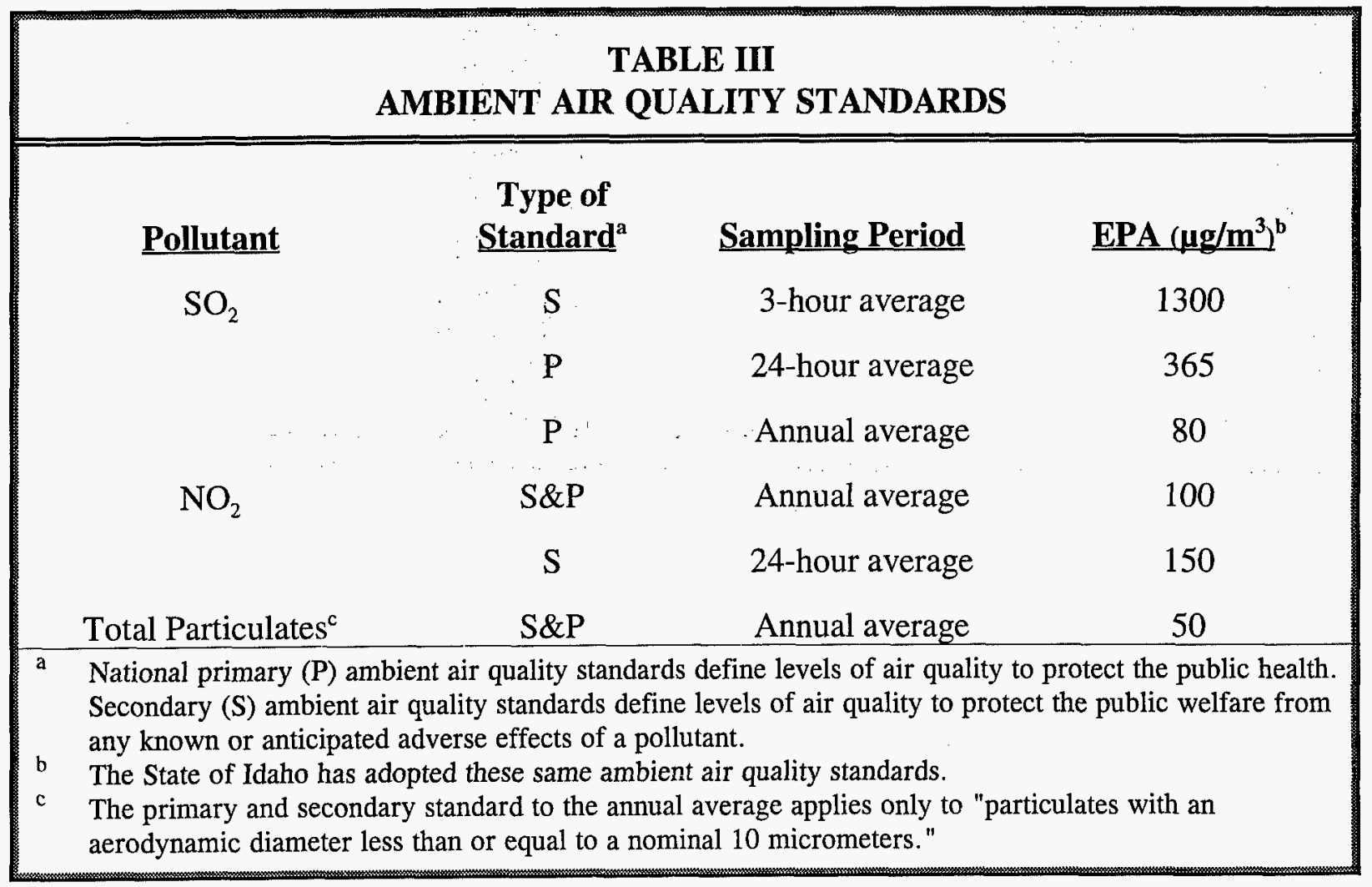




\begin{tabular}{|lc|}
\hline \multicolumn{2}{|c|}{ TABLE IV } \\
\multicolumn{1}{|c|}{ MAXIMUM CONTAMINANT LEVELS FOR NONTRANSIENT } \\
NONCOMMUNITY DRINKING WATER SYSTEMS
\end{tabular}




\section{APPENDIX B \\ STATISTICAL METHODS USED \\ FOR THE ENVIRONMENTAL SURVEILLANCE PROGRAM}

Relatively simple statistical procedures are used to analyze the data from the INEL environmental surveillance program. Environmental Surveillance Program personnel initially review field collection information and analytical results to determine whether there are identifiable errors that would invalidate or limit the use of the results. Examples of these might be power outages at air sampler locations, torn membrane filters, or evidence of laboratory cross-contamination. Data that pass this initial screening are then evaluated for statistical significance with respect to laboratory analytical uncertainties, sample locations, reported releases from INEL operations, meteorological data, and worldwide events that might conceivably have an effect on the INEL environment.

For radiological data, individual analytical results are presented in this report with plus or minus $( \pm)$ two analytical standard deviations $(2 s)$, where all analytical uncertainties have been estimated, and "s" is an estimate of the population standard deviation " $\sigma . "$ Many of the results were less than or equal to $2 \mathrm{~s}$ (and, in fact, some were negative), which means that they were below the minimum detectable concentration. For example, in gamma spectrometric analyses, a given radionuclide is not considered detected unless the net count in the peak is greater than three times its estimated analytical uncertainty (3s). If the result lies in the range of two to three times its estimated analytical uncertainty (2s to $3 \mathrm{~s}$ ), and assuming that the result belongs to a Gaussian distribution, detection of the material by the analysis may be questionable because of statistical variations within the group of samples. If the result exceeds $3 \mathrm{~s}$, there is confidence that the material was detected (or, that the radionuclide was present in the sample).

A deliberate search for specific nuclides can be made and results reported, but such results might include negative values or small positive values where the result is less than or equal to $2 s$. Analyses with results in the questionable range (2s to $3 \mathrm{~s}$ ) are published in this report with the understanding that there is some doubt as to whether the material was actually present.

There are many factors that can influence the result to some degree, and these factors are considered and included in the methods used to determine the estimated uncertainty of the measurement. Uncertainties in measurements near the minimum detectable concentration are primarily caused by counting statistics. For low concentrations near the minimum detectable concentration, the uncertainty in the measurement is nearly equal to the measurement itself, and the lower limit of the range of the measurement approaches "zero." Such a result might not be very reliable because the uncertainty is only an estimate and the actual probability distribution of the results is not usually known. In reality, the material being measured may not actually be present in the sample. Therefore, when analytical results show a measurement very near the minimum detectable concentration, statistical tools, meteorological data, and Site release information are all considered when interpreting and evaluating the results.

Arithmetic means were calculated using actual assay results, regardless of their being 
above or below the minimum detectable concentration. The uncertainty of the mean, or the $95 \%$ confidence interval, was determined by multiplying the standard deviation of the mean (also called the standard error of the mean) or $s /(n)^{1 / 2}$ by the $t_{(0.05)}$ statistic. Means for which the 95\% confidence interval does not include zero were assumed to indicate detectable amounts of activity. In situations where the analytical results of a group of samples are near the minimum detectable concentration, the 95\% confidence interval for the mean may not include zero and thus appears to be statistically significant even though, on the basis of the $2 \mathrm{~s}$ to $3 \mathrm{~s}$ criterion, it is doubtful that any individual sample contained detectable radioactivity.

Geometric means were calculated by summing the natural logarithms (ln) of the positive analytical results, dividing by the number of samples (n), and then transforming the quotient. If the result was either a negative number or a zero, the $\ln$ of the smallest positive, nonzero measurement in the group was used. The $95 \%$ confidence interval was determined by multiplying the standard deviation of the geometric mean by the $t_{(0.05)}$ statistic and then transforming the result. The actual interval is determined by dividing the transformed mean by the transformed 95\% confidence interval term for the lower limit, then multiplying the mean by the confidence interval term for the upper limit.

Unpaired $t$-tests were used to determine whether the annual means for the INEL or boundary stations were greater than the annual means for the distant stations. All statistical tests used a level of significance of 5\% $(\alpha=0.05)$. 


\section{DISTRIBUTION RECORD FOR DOE/ID-12082(95)}

\section{Internal Distribution}

DOE-ID

G. L. Beausoleil, AFM/RWMC

R. D. Carlson, D/RESL

J. T. Case, PM/WM

R. C. Cullison, PM/EP

P. J. Dirkmaat, PM/SNF

J. W. Hobbs, PM/SP

N. R. Jensen, APM/ER

W. D. Jensen, FM/ICPP

R. H. Johnson, AFM/TAN

R. A. King, M/ICC

J. L. Lyle, AAM/OPE

C. A. Mozzer, AFM/IRC

W. N. Sato, AAM/OCS

R. J. Secondo, PM/MG

R. A. Taft, FM/CFA\&WROC

R. R. Throckmorton, CC/OCC

J. M. Wilcynski, M/DOE-ID

A. C. Williams, DAM/OPE

E. J. Ziemianski, FM/TRA

\section{Argonne-West}

J. I. Sackett, Manager

G. C. Marshall, M/ESWM

D. B. Barber (2)

\section{Argonne Area Office/CHO}

E. J. Hughes, Manager

INEL Tech Library (5)

ES\&R Foundation (400)

Total Copies Printed (700)
Lockheed Idaho Technologies Co.

W. J. Denson, President

W. A. Haller, VP/ES\&H

C. L. Tellez, D/RA

M. S. Litus, M/EP

J. R. Mitchell, RA

B. D. Andersen, EMU

L. V. Street, EMU

D. J. Wiggins, RA

R. N. Wilhelmsen, EMU

D. J. Claflin, TP (8)

P. N. Creighton, M/OMB

W. E. Harrison, M/EE\&LS

R. D. Johnson, M/S\&E

K. Langley, M/PRP,RCO

J. L. McAnally, DM/ERWM

R. S. Watkins, AM/ES\&Q

Westinghouse Electric Corporation

J. G. Podgursky, M/RC (2)

J. L. Lucas, NRF Manager

\section{PNRO-IBO}

T. M. Bradley, M/Operations

R.D.E. Newbry, Env. Proj. Off. (2)

U.S. Geological Survey

L. J. Mann, Project Chief

NOAA-ARLFRD

D. H. George, Acting Director 


\section{DISTRIBUTION LIST FOR DOE/ID-12082(95)}

\section{External Distribution}

Richard Aiken, Environmental Audit, DOE-HQ, Washington, DC

W. Bruce Arnell, District Seven Health Department, Idaho Falls, ID

Robert W. Barber, Compliance Programs, DO-HQ, Washington, DC

Robert Bernero, Nuclear Materials Safety and Safeguards, NRC, Washington, DC

Carol M. Borgstrom, NEPA Project Assistance, DOE, Washington, DC (2)

Charles W. Borup, DOE, SR, Aiken, SC

Dave Brekke, Sandia National Laboratory, Livermore, CA

Richard Brey, Idaho State University, Pocatello, ID

Barry Burnell, Southeastern District Health Department, Blackfoot, ID

Michael Butler, Environmental Programs and Projects, DOE, BH, Upton, NY

Robert Bryce, Pacific Northwest Laboratory, Richland, WA

Linford J. Campbell, Idaho Department of Water Resources, Boise, ID

William R. Carlton, Savannah River Technology Center, Aiken, SC

Carrie M. Carter, DOE-OAK, Oakland, CA

Honorable Helen Chenoweth, U. S. House of Representatives, Washington, DC
Audrey Cole, Division of Environmental Quality, IDHW, Pocatello, ID

Wally Cory, Division of Environmental Quality, IDHW, Boise, ID

J. Donald Cossairt, Fermi Laboratory, Batavia, IL

Honorable Larry E. Craig, U.S. Senate, Washington, DC

Honorable Mike Crapo, U. S. House of Representatives, Washington, DC

James T. Davis, Environment, Safety \& Quality Assurance Division, DOE-OAK, Oakland, CA

Weldon Dillow, Environmental Protection Division, DOE-OR, Oak Ridge, TN

Roger L. Dirkes, Manager, Surface Environmental and Surveillance Project, PNL, Richland, WA

James Donnelly, DOE-OR, Oak Ridge, TN

Daniel A. Dreyfus, Nuclear Energy, DOEHQ, Washington, DC

Don Elle, DOE-NV, Las Vegas, NV

Fred D. Ferate, II, Environmental Science Department, NTS, Mercury, NV

Robert Ferguson, INEL Oversight Office, Idaho Department of Health \& Welfare, Idaho Falls, ID

Michael Flannigan, DOE, Argonne Area Office--East, Argonne, IL 
Thomas F. Gesell, Radiation Safety, Idaho State University, Pocatello, ID

Norbert Golchert, Occupational Health \& Safety Department, ANL, Argonne, IL

Orville Green, Idaho Department of Health \&Welfare, Boise, ID

Andrea Gralak, Center for Environmental Information Management, Wạshington, D.C.

Thomas P. Grumbly, Office of Environmental Restoration and Waste Management, HQ, Washington, DC

William Gunter, Criteria and Standards Division, EPA, Washington, DC (2)

Joy Haftel, Congressional Information Service, Bethesda, MD

John B. Hall, Quality, Safety \& Health Programs, DOE-RL, Richland, WA

William L. Harrell, Environmental Protection Division DOE, AL, Albuquerque, NM

James D. Heffner, Savannah River Site, Aiken, SC

Eva Hickey, PNL, Richland, WA

Gerald V. Hurst, Public Health District Five, Twin Falls, ID

Hue-Su Hwang, Sandia National Laboratory, Albuquerque, NM

William Isherwood, LLNL, Livermore, CA

Paul Jehn, Idaho Department of Health and Welfare, Boise, ID

Matthew Johansen, DOE-LAAO, Los Alamos, NM
Jim Johnston, Division of Environmental Quality, Idaho Department of Health \& Welfare, Idaho Falls, ID

Joseph Juetten, DOE-OAK, Oakland, CA

Honorable Dirk Kempthorne, U. S. Senate, Washington; D.C.

J. P. Kennedy, DOE-CH, Argonne, IL

Michael A. Kilpatrick, Environmental Audit, DOE-HQ, Washington, DC

Michael H. Kleinrock, Environmental Compliance, DOE-HQ, Washington, DC

Patricia Kraps, FERMCO, Cincinnati, OH

Philip Krey, Environmental Measurements Laboratory, DOE-CH, New York, NY

Andrew C. Lawrence, Environmental Compliance, DOE-HQ, Washington, DC

Jerry Leitch, Radiation Division, EPA, Seattle, WAA

Larry J. Madl, WIPP, Carlsbad, NM

Helen McCammon, Ecological Research, OHER, DOE-HQ, Washington, DC

Daniel A. McGrath, Pantex, Amarillo, TX

Robert P. Miltenberger, Brookhaven National Laboratory, Upton, NY

Leland Mink, University of Idaho, Moscow, ID

Anita Mullen, Environmental Monitoring \& Support Laboratory, EPA, Las Vegas, NV

John B. Murphy, ORNL, Oak Ridge, TN 
Ross Natoli, Environmental Compliance

Division, DOE-HQ, Washington, DC

Vicki Snitzler-Neek, Craters of the Moon

National Monument, Arco, ID

Richard W. Oldham, Environmental Monitoring Support Services, WVNS, West Valley, NY

William S. Osburn, Jr., Ecological Research Division, OHER, DOE, Washington, DC

Jack Palmer, Division of Environmental Quality, Idaho Department of Health \& Welfare, Pocatello, ID

Raymond Pelletier, Environmental Guidance, DOE, Washington, DC

James A. Phoenix, Technical Programs Branch, DOE, Los Alamos, NM

Esteban Picazo, West Valley Nuclear Services, West Valley, NY

Allen Reed, Reed's Dairy, Idaho Falls, ID

Leslie L. Reed, WIPP, Carlsbad, NM

Lotwick Reese, Idaho Department of Water Resources, Boise, ID

Gene Runkle, HPD, DOE-AL, Albuquerque, NM

Robie Russell, Region 10, EPA, Seattle, WA

L. E. Scarburgh, EPA Idaho Operations

Office, Boise, ID

Randal Scott, Compliance and Program Coordination, DOE-HQ, Washington, DC

George Setlock, Health, Safety and Environment, Rocky Flats Plant, Golden, CO
Rajendra K. Sharma, Fuel Cycle \& Test Programs, DOE, HQ, Washington, DC

George Sherwood, DOE-HQ, Germantown, MD

Michael Silverman, EPA Idaho Operations Office, Boise, ID

John M. Sims, LLNL, Livermore, CA

C. L. Soden Environmental Protection Division, DOE-AL, Albuquerque, NM

Richard Suckel, Environmental Coordinator, Shoshone-Bannock Tribe, Ft. Hall, ID

Lee S. Sygitowicz, NTS, Las Vegas, NV

A. L. Taboas, DOE-CH, AAO-East, Argonne, IL

Rudy T. Taylor, Environmental Protection

Dept, Pantex, Amarillo, TX

Lynne Kukler Wade, Idaho, Nevada and San Francisco Operations Division, DOE-HQ, Washington, DC

Dana Ward, DOE-RL, Richland, WA

John Welhan, Department of Geology, ISU, Pocatello, ID

Doug Wells, INEL Oversight Program, IDHW, Boise, ID

Spence Wood, Department of Geology and Geophysics, BSU, Boise, ID

Norman Young, Idaho Department of Water Resources, Boise, ID 
County Commissioners:

Bannock County, Pocatello, ID

Bingham County, Blackfoot, ID

Bonneville County, Idaho Falls, ID

Butte County, Arco, ID

Clark County, Dubois, ID

Jefferson County, Rigby, ID

Lemhi County, Salmon, ID

Madison County, Rexburg, ID
Public Reading Rooms and INEL ER\&WM repositories

INEL Site Specific Advisory Board

Foundation Board of Directors 
M98002871

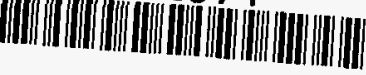

Report Number (14) DOE/1D--12082(95)

$$
\text { ESRF- }-014
$$

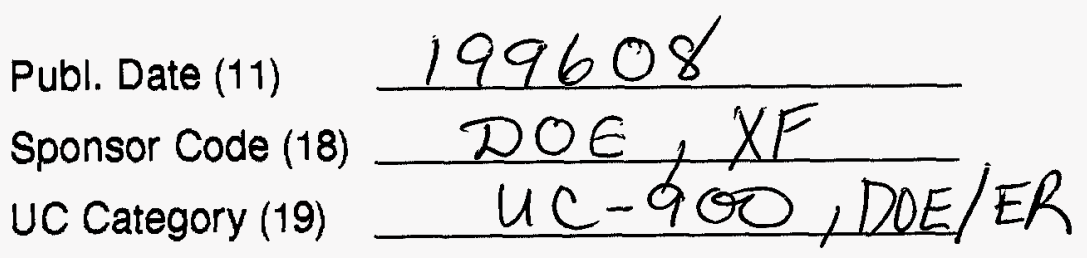

no.1332,15 in folder

DOE 